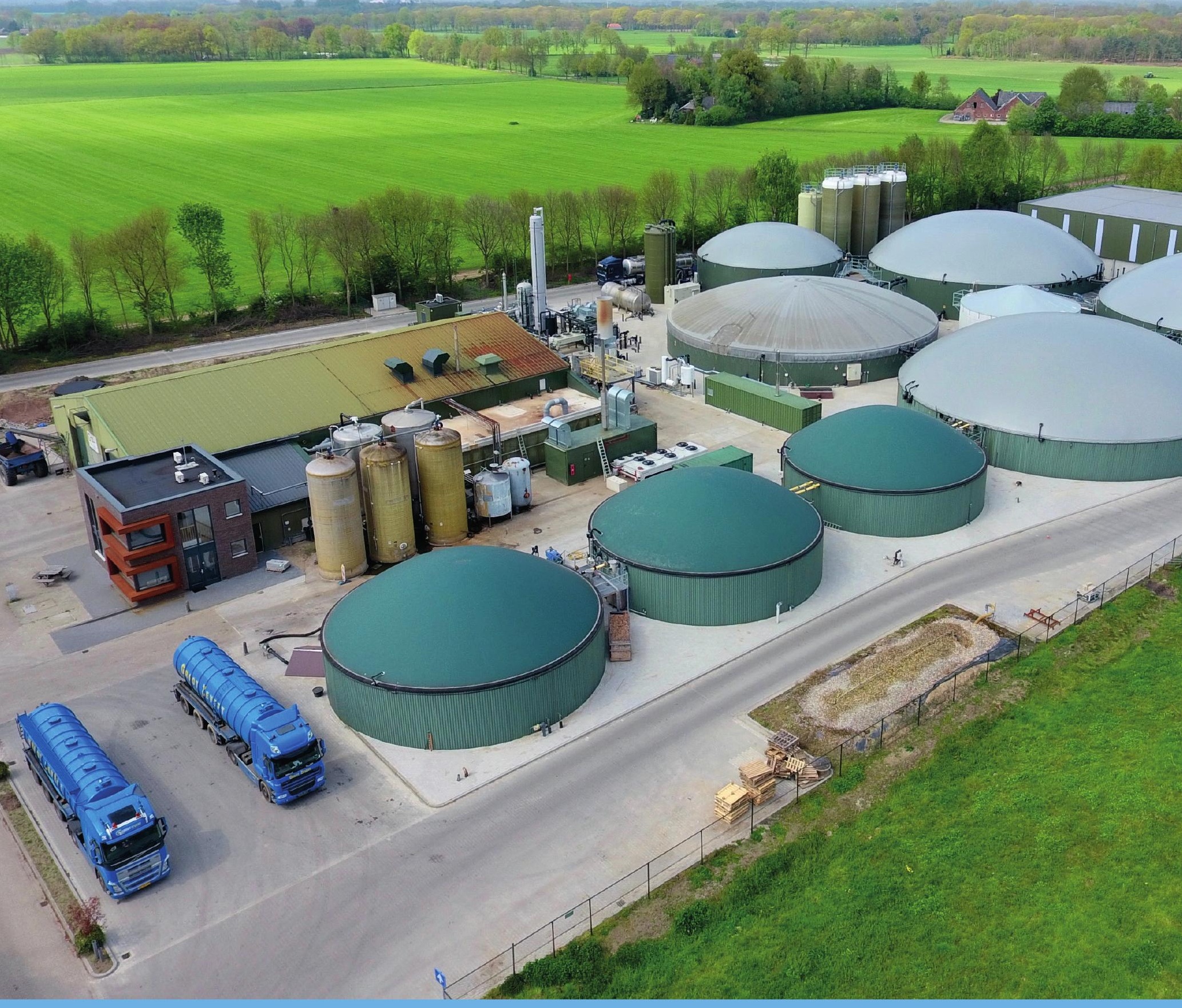

\title{
Evaluatie van verwerkingsinstallaties voor mest en co-vergiste mest
}





\section{Evaluatie van verwerkingsinstallaties voor mest en co-vergiste mest}

Inge C. Regelink, Jasper L. van Puffelen, Phillip A.I. Ehlert, Oscar F. Schoumans

Dit onderzoek is uitgevoerd door Wageningen Environmental Research met financiering van TKI BBE (project TKI-BBE-1704).

Wageningen Environmental Research

Wageningen, november 2021

Gereviewd door:

Chantal M.J. Hendriks (onderzoeker, team duurzaam bodemgebruik)

Akkoord voor publicatie:

Gert Jan Reinds (teamleider, team duurzaam bodemgebruik)

Rapport 3120

ISSN 1566-7197 
Regelink, I.C., Van Puffelen, J.L., Ehlert, P.A.I., Schoumans, O.F., 2021. Evaluatie van verwerkingsinstallaties voor mest en co-vergiste mes. Wageningen, Wageningen Environmental Research, Rapport 3120. 174 blz.; 58 fig.; 26 tab.; 43 ref.

Dit eindrapport van het vierjarige TKI Publiek-Private Samenwerking (PPS)-project 'Meerwaarde Mest en Mineralen 2: nutriënten terugwinning uit mest' bevat de evaluatie van vijf grootschalige verwerkingsinstallaties voor dierlijke mest of co-vergiste dierlijke mest (digestaat). De verschillende gebruikte verwerkingstechnieken omvatten hygiënisatie, dik/dun-scheiding, drogen en persen van de dikke fractie en productie van mineralenconcentraat en loosbaar water door middel van membraanfiltratie en ionenwisselaars of door middel van membraanfiltratie en biologische zuivering. Op basis van een uitgevoerde monitoring van deze bedrijven wordt ingegaan op de behaalde scheidingsrendementen, de massabalansen, de verwerkingskosten en de samenstelling en agronomische en milieukundige kwaliteit van de eindproducten. Ook de milieuvoordelen van verwerking zijn berekend via een beknopte levenscyclusanalyse (LCA). Daarnaast stond de bouw, monitoring en evaluatie van een innovatieve installatie om de dikke fractie van co-vergiste dierlijke mest te scheiden in een fosfaatmeststof en een fosfaatarme bodemverbeteraar centraal. Er worden aanbevelingen gedaan voor verdere duurzame ontwikkeling van mestverwerking in Nederland.

This final report of the four-year PPS (public-private collaboration) project 'Meerwaarde Mest en Mineralen 2 (More Value from Manure and Minerals 2): nutrient recovery from manure' contains the evaluation of five large-scale installations for processing of animal manure or co-digested animal manure (digestate). The different processing techniques of the installations include hygienisation, solid-liquid separation, drying and pressing of the solid fraction and production of mineral concentrate and dischargeable water by means of membrane filtration and ion exchangers or by means of membrane filtration and biological treatment. Based on a performed monitoring of the installations the achieved separation efficiencies, (nutrient) mass balances, processing costs and composition, agronomic and environmental quality of the end products, have been evaluated. Also the environmental gains of processing were calculated via a simplified life cycle assessment (LCA). Moreover, the construction, monitoring and evaluation of an innovative installation which separates the solid fraction of co-digested animal manure into a phosphate $(P)$ fertiliser and an organic low-P soil improver was a central part of the project. Finally, recommendations are given for environmentally beneficial adaptations of manure processing installations in the Netherlands.

Trefwoorden: mestverwerking, mestscheiding, mestverwaarding, co-vergiste mest, dierlijke mest, (minerale) stikstof, fosfaat, kalium, nutriënten, koolstof, organische stof, mineralenconcentraat, NKconcentraat, kunstmestvervanger, biogebaseerde meststoffen

Dit rapport is gratis te downloaden van https://doi.org/10.18174/554452 of op www.wur.nl/environmental-research (ga naar 'Wageningen Environmental Research' in de grijze balk onderaan). Wageningen Environmental Research verstrekt geen gedrukte exemplaren van rapporten. 
2021 Wageningen Environmental Research (instituut binnen de rechtspersoon Stichting Wageningen Research), Postbus 47, 6700 AA Wageningen, T 0317480700 ,

www.wur.nl/environmental-research. Wageningen Environmental Research is onderdeel van Wageningen University \& Research.

- Overname, verveelvoudiging of openbaarmaking van deze uitgave is toegestaan mits met duidelijke bronvermelding.

- Overname, verveelvoudiging of openbaarmaking is niet toegestaan voor commerciële doeleinden en/of geldelijk gewin.

- Overname, verveelvoudiging of openbaarmaking is niet toegestaan voor die gedeelten van deze uitgave waarvan duidelijk is dat de auteursrechten liggen bij derden en/of zijn voorbehouden.

Wageningen Environmental Research aanvaardt geen aansprakelijkheid voor eventuele schade voortvloeiend uit het gebruik van de resultaten van dit onderzoek of de toepassing van de adviezen.

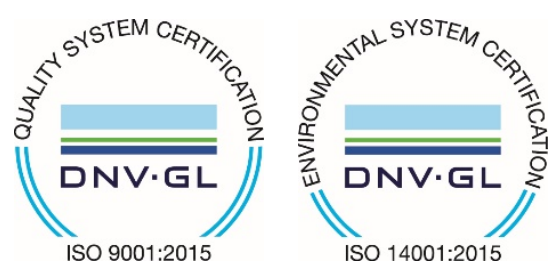

Wageningen Environmental Research Rapport 3120 | ISSN 1566-7197

Foto omslag: Groot Zevert Vergisting in Beltrum; copyright: Groot Zevert Vergisting.
Wageningen Environmental Research werkt sinds 2003 met een ISO 9001 gecertificeerd kwaliteitsmanagementsysteem. In 2006 heeft Wageningen Environmental Research een milieuzorgsysteem geïmplementeerd, gecertificeerd volgens de norm ISO 14001.

Wageningen Environmental Research geeft via ISO 26000 invulling aan haar maatschappelijke verantwoordelijkheid. 



\section{Inhoud}

$\begin{array}{ll}\text { Verantwoording } & 9\end{array}$

Woord vooraf $\quad 11$

$\begin{array}{ll}\text { Samenvatting } & 13\end{array}$

$1 \quad$ Inleiding $\quad 17$

$\begin{array}{lll}1.1 & \text { Mestbeleid en kringlooplandbouw } & 17\end{array}$

$\begin{array}{lll}1.2 & \text { Kringlooplandbouw } & 18\end{array}$

1.3 Verwerkingscapaciteit en mestverwerkingstechnieken 18

1.4 Doelstelling en aanpak 19

$\begin{array}{llr}1.5 & \text { Leeswijzer } & 19\end{array}$

2

$\begin{array}{ll}\text { Materiaal en Methoden } & \mathbf{2 1}\end{array}$

2.1 Mest- en digestaatverwerkers $\quad 21$

2.2 Bemonstering en chemische analyse van monsters $\quad 22$

2.2.1 Chemische analyses van de monsters $\quad 23$

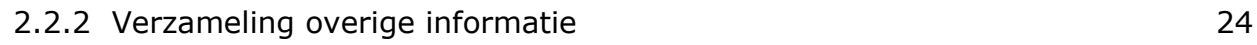

2.3 Berekening van scheidingsrendementen en massabalansen $\quad 24$

2.3.1 Loonbedrijf Dekker, Maatschap Van Amstel en Merensteyn 24

2.3.2 Groot Zevert Vergisting $\quad 25$

$\begin{array}{ll}2.3 .3 \text { Ecoson } & 26\end{array}$

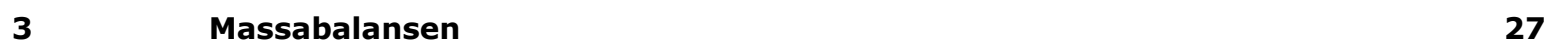

3.1 Groot Zevert Vergisting - GENIAAL $\quad 27$

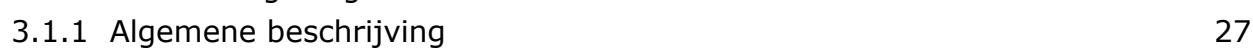

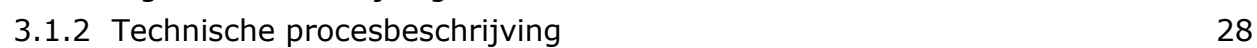

$\begin{array}{ll}3.1 .3 \text { Scheidingsrendementen } & 29\end{array}$

$\begin{array}{ll}3.1 .4 \text { Massabalans } & 35\end{array}$

3.1.5 Chemie- en energieverbruik 39

3.2 Groot Zevert Vergisting - RePeat $\quad 40$

3.2.1 Algemene beschrijving $\quad 40$

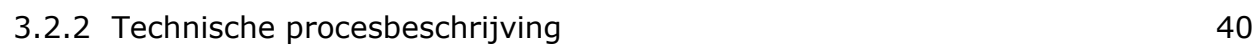

$\begin{array}{ll}3.2 .3 \text { Scheidingsrendementen } & 42\end{array}$

3.2.4 Massabalans $\quad 45$

3.2.5 Trends in de samenstelling van de eindproducten $\quad 46$

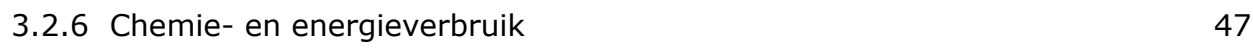

$\begin{array}{lll}3.3 & \text { Loonbedrijf Dekker } & 48\end{array}$

$\begin{array}{ll}\text { 3.3.1 Algemene beschrijving } & 48\end{array}$

$\begin{array}{ll}\text { 3.3.2 Technische procesbeschrijving } & 48\end{array}$

$\begin{array}{ll}3.3 .3 \text { Scheidingsrendementen } & 49\end{array}$

3.3.4 Massabalans $\quad 50$

3.3.5 Chemie- en energieverbruik $\quad 51$

3.4 Maatschap Van Amstel $\quad 52$

3.4.1 Algemene beschrijving $\quad 52$

3.4.2 Technische procesbeschrijving $\quad 52$

3.4.3 Scheidingsrendementen $\quad 53$

$\begin{array}{ll}3.4 .4 \text { Massabalans } & 58\end{array}$

$\begin{array}{ll}\text { 3.4.5 Chemie- en energieverbruik } & 60\end{array}$ 
$\begin{array}{lll}3.5 & \text { Merensteyn } & 61\end{array}$

3.5.1 Algemene beschrijving $\quad 61$

3.5.2 Technische procesbeschrijving $\quad 61$

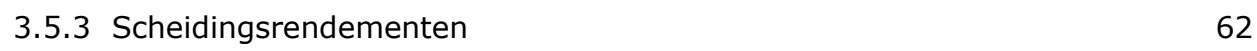

3.5.4 Massabalans $\quad 66$

3.5.5 Chemie- en energieverbruik 69

$\begin{array}{lll}3.6 & \text { Ecoson } & 69\end{array}$

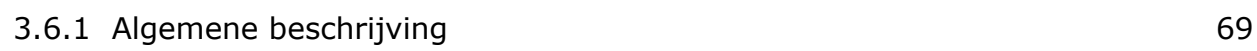

$\begin{array}{ll}3.6 .2 \text { Technische procesbeschrijving } & 70\end{array}$

$\begin{array}{ll}3.6 .3 \text { Scheidingsrendementen } & 71\end{array}$

$\begin{array}{ll}3.6 .4 \text { Massabalans } & 73\end{array}$

3.6.5 Chemie- en energieverbruik 76

$\begin{array}{lll}3.7 & \text { Twence } & 76\end{array}$

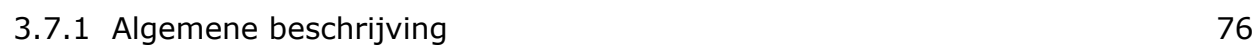

$\begin{array}{lll}3.8 & \text { Synthese massabalansen } & 77\end{array}$

$\begin{array}{lll}3.9 & \text { Conclusies } & 81\end{array}$

4.1 Ammonia membrane stripping van NK-concentraat door BLUE-tec $\quad 82$

4.2 Membraandestillatie van NK-concentraat door RN Solutions en Kumac 83

5.1 Mest en digestaat $\quad 85$

$\begin{array}{lll}5.2 & \text { NK-concentraten en dunne fracties } & 87\end{array}$

$\begin{array}{ll}5.2 .1 & \text { Samenstelling }\end{array}$

$\begin{array}{ll}5.2 .2 \text { Criteria kunstmestvervanger } & 89\end{array}$

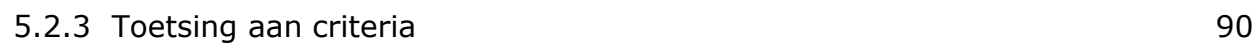

5.2.4 Evaluatie landbouwkundige kwaliteit $\quad 91$

$\begin{array}{lll}5.3 & \text { Vaste organische meststoffen } & 94\end{array}$

5.3.1 Samenstelling 94

5.3.2 Criteria bij export en de nieuwe EU-meststoffenverordening 96

5.3.3 Toetsing aan criteria voor zware metalen 97

5.3.4 Evaluatie landbouwkundige kwaliteit $\quad 97$

5.3.5 Evaluatie fosfaatarme bodemverbeteraar 98

$\begin{array}{ll}\text { 5.3.6 Veenvervanger uit digestaat } & 100\end{array}$

5.4 Fosfaatprecipitaat 100

5.5 Loosbare effluenten $\quad 101$

$\begin{array}{ll}\text { 5.5.1 Prestatiekenmerken } & 101\end{array}$

$\begin{array}{ll}5.5 .2 \text { Samenstelling en toetsing } & 101\end{array}$

$\begin{array}{lll}5.6 & \text { Conclusies producten } & 102\end{array}$

$\begin{array}{lrr}\text { Kosten } & 104\end{array}$

6.1 Inleiding 104

6.2 Uitgangspunten 105

6.2.1 Scenario's voor verwerking van varkensdrijfmest $\quad 105$

6.2.2 Massabalans en energie- en chemieverbruik van de

$\begin{array}{ll}\text { verwerkingsinstallaties } & 105\end{array}$

$\begin{array}{ll}6.2 .3 \text { Vergisting } & 106\end{array}$

6.2.4 Kostprijzen energie en chemie $\quad 107$

$\begin{array}{ll}\text { 6.2.5 Afzetkosten eindproducten } & 107\end{array}$

6.2.6 Afschrijving, onderhoud en bedrijfsvoering van
mestverwerkingsinstallaties

6.2.7 Inkomsten uit vervangende verwerkingsovereenkomsten 110

$\begin{array}{lll}6.3 & \text { Resultaten } & 110\end{array}$

6.3.1 Kostprijzen mestverwerking (scenario's A en B) 110

6.3.2 Kostprijs digestaatverwerking (scenario C) 111 
6.4 Kosten en baten fosfaatafscheiding met RePeat $\quad 114$

6.5 Conclusies

7.2 Scenario's en uitgangspunten levenscyclusanalyse

7.2.1 Afbakening, functionele eenheid en scenario's 118

$\begin{array}{ll}7.2 .2 \text { Massabalansen } & 120\end{array}$

7.2.3 Transportafstanden 121

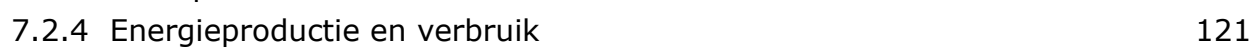

$\begin{array}{ll}7.2 .5 \text { Chemieverbruik } & 123\end{array}$

7.2.6 Bespaarde productie van stikstofkunstmest $\quad 123$

$\begin{array}{ll}7.2 .7 \text { Methaanemissies } & 123\end{array}$

$\begin{array}{ll}7.2 .8 \text { Ammoniakemissies } & 126\end{array}$

$\begin{array}{lr}\text { 7.2.9 Lachgasemissies } & 128\end{array}$

$\begin{array}{llr}7.3 & \text { Resultaten en discussie } & 129\end{array}$

$\begin{array}{ll}\text { 7.3.1 Vermeden methaanemissies } & 129\end{array}$

$\begin{array}{ll}7.3 .2 \mathrm{CO}_{2} \text {-voetafdruk } & 129\end{array}$

$\begin{array}{ll}7.3 .3 \text { Discussie } & 132\end{array}$

7.3.4 Emissies van ammoniak 133

$\begin{array}{llr}7.4 & \text { Conclusies } & 135\end{array}$

$8 \quad$ Stikstof- en fosfaatbalans Nederlandse landbouw

136

8.1 Trends in nutriëntenbalansen 136

8.2 Stikstofbenutting bij gebruik RENURE-materialen $\quad 139$

$\begin{array}{lll}8.3 \text { Conclusies } & 142\end{array}$

9 Synthese $r$

$9.1 \quad$ Inleiding 143

9.2 Verwerking van fosfaat 143

9.2.1 Dikke fractie of korrels $\quad 143$

9.2.2 Opwerking tot veenvervanger en fosfaatmeststof 144

9.3 Stikstofverwaarding $\quad 145$

9.4 Emissies van broeikasgassen en ammoniak 146

$\begin{array}{lll}9.5 & \text { Aanbevelingen } & 147\end{array}$

$10 \quad$ Conclusies \& vooruitblik $r 149$

$\begin{array}{ll}\text { Literatuur } & 151\end{array}$

Bijlage 1 154

Bijlage $2 \quad 156$

$\begin{array}{lr}\text { Bijlage } 3 & 160\end{array}$

Bijlage $4 \quad 170$ 



\section{Verantwoording}

Rapport: 3120

Projectnummer: TKI-BBE-1704

Wageningen Environmental Research (WENR) hecht grote waarde aan de kwaliteit van zijn eindproducten. Een review van de rapporten op wetenschappelijke kwaliteit door een referent maakt standaard onderdeel uit van ons kwaliteitsbeleid.

Akkoord Referent die het rapport heeft beoordeeld,

functie: Onderzoeker

naam: Chantal Hendriks

datum: 25-09-2021

Akkoord teamleider voor de inhoud,

naam: Gert Jan Reinds

datum: $\quad 06-10-2021$ 


\section{Woord vooraf}

Dit rapport is het tweede en laatste rapport van het TKI Publiek-Private Samenwerking (PPS)-project 'Meerwaarde Mest en Mineralen 2: nutriënten terugwinning uit mest' dat in de periode 2017-mei 2021 is uitgevoerd met financiering van TKI BBE (project TKI-BBE-1704). De kern van dit project was het doorontwikkelen van een techniek, die in het kader van het PPS-project 'Meerwaarde Mest en Mineralen 1' was ontwikkeld, om fosfaat uit dierlijke mest te winnen om het fosfaatoverschot in de vorm van mest te verlagen. Onderdeel daarvan was de bouw van een pilotinstallatie om de mogelijkheden in de praktijk te demonsteren. Het eerste rapport binnen dit project, Phosphorus recovery from co-digestated pig slurry, omvat alle lab- en praktijktesten met betrekking tot de fosfaatafscheiding van deze techniek en vormde de basis voor de te bouwen installatie.

Ontwikkeling van de techniek voor fosfaatwinning (RePeat) heeft plaatsgevonden bij Groot Zevert Vergisting in Beltrum met verschillende pilotinstallaties. In het kader van een $\mathrm{H} 2020$-project SYSTEMIC (EC project 730400) is financiering gevonden voor de bouw van een grootschalige installatie van het RePeat-systeem voor scheiding van de dikke fractie van co-vergiste dierlijke mest (digestaat) in een bodemverbeteraar en fosfaatmeststof. Het RePeat-systeem is een uitbreiding op het eerder gerealiseerde, door Nijhuis Industries (Doetinchem) ontwikkelde, GENIAAL-systeem voor scheiding van co-vergiste dierlijke mest in loosbaar water, NK-concentraat en dikke fractie.

Naast de ontwikkeling van een installatie voor de winning van fosfaat uit de dikke fractie was er de wens om ook bij andere mestverwerkers de installaties te evalueren en mogelijkheden voor procesverbeteringen te verkennen. Dit is uitgevoerd in samenwerking met vier mestverwerkers, te weten Maatschap Van Amstel (Lith), Loonbedrijf Dekker (Putten), Merensteyn (Ysselsteyn), onderdeel van Mestac en Ecoson (Son). Mede door de bereidheid om veel informatie te delen, kon een uitgebreide analyse worden uitgevoerd en zijn aanvullende testen met opkomende scheidingstechnieken uitgevoerd. De uitkomsten hiervan en een evaluatie van duurzaamheidsvoor- en nadelen staan centraal in dit tweede rapport binnen het TKI-project.

Hierbij willen we dan ook heel graag Arjan Prinsen, Bennie Dimmendaal, Sander Bruil en Roel Beunk (Groot Zevert Vergisting) en Leo van Amstel (Maatschap Van Amstel), Bas van den Bergh (Merensteyn), Jan Dekker (Loonbedrijf Dekker), Richard van Lijssel en Arnt Vlaardingerbroek (Ecoson) hartelijk bedanken voor hun inzet en bijdragen aan het project en de totstandkoming van deze synthese.

Daarnaast willen we LTO (Kees Kroes, Rembert van Noort) als initiator en penvoerder van het project en de andere leden van de projectgroep, Andy Roeloffzen en Gerben Spit (TWENCE), Wilbert Menkveld, Geo Smith en Sjoerd Everlo (Nijhuis Industries), Jaap Uenk (DOFCO), Anthony Zanelli (ICL Fertilizers), Jan Roefs (NCM) en Johan Temmink (ForFarmers) hartelijk bedanken voor de constructieve bijdrage en feedback tijdens de verschillende bijeenkomsten.

In de afgelopen vier jaar zijn er grote stappen gezet, maar zoals altijd zijn er nog open einden. Een deel daarvan zal in het TKI-project BIOVALOR (TKI - LWV20.119) verder worden opgepakt. 


\section{Samenvatting}

Dit rapport is het eindrapport van het project 'Meerwaarde Mest en Mineralen 2' waarmee, gezamenlijk met vijf grootschalige mestverwerkers, inzicht is verkregen in de werking van verschillende mestverwerkingstechnieken met als doel om (i) kennis te delen binnen de sector en (ii) verwerkingsinstallaties te evalueren qua scheidingsrendementen, massabalansen, kosten, productkwaliteit en milieuvoordelen.

Mestverwerking is ontstaan vanuit de noodzaak om overschotten aan mest - nu nog voornamelijk een overschot aan fosfaat dat niet plaatsbaar is op Nederlandse landbouwgronden - buiten de Nederlandse landbouw af te zetten. Dit rapport richt zich op de verwerking van varkensdrijfmest, al dan niet na vergisting met co-producten, omdat de varkenssector niet-grondgebonden is en daarom een groot deel van de mest (vanuit de huidige Meststoffenwet) verplicht moet laten verwerken. Hoofdstuk 1 geeft een algemene inleiding en in hoofdstuk 2 worden de methoden beschreven.

Hoofdstuk 3 geeft een gedetailleerd overzicht van de werking, scheidingsrendementen, massabalansen en het chemieverbruik van vijf operationele verwerkingsinstallaties. Het betreft twee installaties voor verwerking van varkensdrijfmest en drie installaties voor verwerking van digestaat dat ontstaat bij co-vergisting van mest. Loonbedrijf Dekker bedrijft een co-vergistingsinstallatie en verwerkt het digestaat daarvan enkel door scheiding in een dikke fractie ( $218 \mathrm{~kg} / \mathrm{ton}$ digestaat) en een dunne fractie ( $833 \mathrm{~kg} /$ ton digestaat) vanwege de nabijheid van akkerbouwgebied met vraag naar dunne fractie. De dikke fractie wordt na hygiënisatie geëxporteerd.

Groot Zevert Vergisting (GZV) is gevestigd in de Achterhoek en vergist varkensdrijfmest en diverse co-producten waarna het digestaat gescheiden wordt tot dikke fractie (148 kg/ton digestaat), stikstofkalium (NK-)concentraat (313 kg/ton digestaat) en loosbaar water (183 kg/ton digestaat). Het NKconcentraat wordt, na blending met minerale stikstofmeststoffen, afgezet als kunstmestvervanger in de regio. Ook ontstaat een reststroom (440 kg/ton digestaat), die bestaat uit een blend van dikke fractie van de tweede decanter centrifuge en concentraat van de microfiltratie, die onder de gebruiksnorm dierlijke mest wordt afgezet. Het RePeat-systeem van GZV scheidt dikke fractie van digestaat ( $22 \mathrm{~g} \mathrm{P}_{2} \mathrm{O}_{5} / \mathrm{kg}$ ) in een fosfaatmeststof en een fosfaatarme bodemverbeteraar die circa $2,5 \mathrm{~g}$ $\mathrm{P}_{2} \mathrm{O}_{5} / \mathrm{kg}$ bevat. De installatie draait nog niet zoals gewenst, omdat de fosfaatmeststof wordt gewonnen in de vorm van een waterig calciumfosfaatslib waardoor geen transportvoordeel wordt behaald.

Merensteyn scheidt varkensdrijfmest via een zeefbandpers, Dissolved Air Flotation (DAF-)installatie en omgekeerde osmose-installatie tot een dikke fractie (194 kg/ton mest), NK-concentraat (329 kg/ton mest) en loosbaar water ( $594 \mathrm{~kg} /$ ton mest). Maatschap Van Amstel bedrijft een vergelijkbare installatie en verwerkt daarmee varkensdrijfmest tot dikke fractie (179 kg/ton mest), NK-concentraat (546 kg/ton mest) en loosbaar water (407 kg/ton mest). De NK-concentraten van GZV, Merensteyn en Maatschap Van Amstel worden onder een tijdelijke vrijstelling afgezet in de regio als kunstmestvervanger en voldoen tevens aan de door het Joint Research Centre (JRC) voorgestelde criteria voor RENURE-materialen (stikstofkunstmestvervangers van dierlijke mest).

Ecoson bedrijft een vergistingsinstallatie voor varkensdrijfmest en ongeboren mest (mest die bij het slachten uit een dier wordt verwijderd). De dikke fractie van het digestaat wordt gedroogd en verwerkt tot mestkorrels (65 kg/ton digestaat). De dunne fractie van het digestaat wordt, via diverse behandelingsstappen, gezuiverd tot loosbaar water. Ecoson maakt hierbij gebruik van restwarmte vanuit andere bedrijfsactiviteiten en een eigen, hoogwaardige waterzuiveringsinstallatie voor verwijdering van stikstof en fosfaat. Voor alle verwerkingslocaties geldt dat de massa van de eindproducten tezamen groter is dan $1000 \mathrm{~kg} /$ ton ingaande mest of digestaat door toevoeging van chemie (o.a. polymeer, zwavelzuur, ijzersulfaat) en/of spoelwater. Een zesde verwerkingsinstallatie, die van Twence, was ten tijde van schrijven nog in ontwikkeling, de bouw is recentelijk gestart. Twence zal vanaf 2022 mest vergisten en verwerken tot een dikke fractie, kaliumconcentraat en 
ammoniakwater. Het ammoniakwater zal gebruikt worden als vervanger van synthetisch ammoniakwater in een eigen rookgasreinigingsinstallatie voor verwijdering van $\mathrm{NO}_{\mathrm{x}}$.

Deze zes verwerkingsinstallaties laten zien dat er een grote verscheidenheid bestaat in verwerkingsconcepten afgestemd op locatie- en regiospecifieke condities, waaronder de samenstelling van de mest of het digestaat, de lokale vraag naar meststoffen/herwonnen producten en de beschikbaarheid van restwarmte of andere faciliteiten zoals een eigen waterzuivering. Alle mestverwerkingsinstallaties behalen een voordeel op het aantal massakilometers voor afzet van de eindproducten ten opzichte van export van drijfmest of digestaat zonder scheiding. Transportvoordeel wordt gerealiseerd door afzet van eindproducten in de regio (bijvoorbeeld NK-concentraat als kunstmestvervanger) en/of door productie van loosbaar water. Er zijn grote verschillen in scheidingsrendementen, chemieverbruik en volumes aan loosbaar water en/of reststromen tussen de installaties. Deze verschillen zijn deels het gevolg van strategische keuzes en economische afwegingen. Zo is toevoeging van ijzersulfaat erg effectief in het verhogen van de fosfaatafscheiding van de eerste scheidingsstap. Echter, het resulteert ook in een verhoogd zwavelgehalte in het NKconcentraat (nadelig vanwege risico op te hoge zwavelgiften) en een verhoogd ijzergehalte in de dikke fractie (nadelig voor de gewasbeschikbaarheid van fosfaat). Voor sommige verwerkers is dit een reden om ijzersulfaat te mijden en/of alternatieven te gebruiken, zoals magnesiumchloride. Tevens zijn er grote verschillen in de hoogte van de zwavelzuurdosering op de omgekeerde osmose-installaties. Alle installaties voegen polymeer toe ten behoeve van de eerste scheidingsstap. Kennisuitwisseling kan bijdragen aan verdere optimalisatie van de verwerkingsprocessen.

Hoofdstuk 4 gaat in op de kennisbehoefte van verwerkers naar technieken om NK-concentraat te scheiden in een stikstof- $(\mathrm{N})$ en een kalium-(K)meststof of verder in te dikken. Hiervoor zijn verkennende proeven uitgevoerd met nieuwe membraantechnieken, maar een verdere beoordeling van de economische haalbaarheid was geen onderdeel van dit project.

Hoofdstuk 5 geeft een evaluatie van de samenstelling van de door de verwerkers geproduceerde meststoffen qua landbouwkundige behoefte en milieuwet- en regelgeving. Dikke fracties en geperste mestkorrels zijn primair fosfaatmeststoffen en worden buiten Nederland afgezet. Vanaf 2022 is de nieuwe EU-meststoffenregeling van kracht en dit kan perspectieven bieden voor het vrij verhandelen van dikke fracties van digestaat. Dikke fracties van mest of van andere organische meststoffen zijn vooralsnog uitgesloten als meststof met EC-label. Vanaf medio 2022 is vrije verhandeling van dikke fracties van digestaat onder CE-markering en onder daarvoor geldende bepalingen mogelijk. Gehalten aan koper en zink zijn daarbij een aandachtspunt, net zoals het toevoegen van niet volledig biologisch afbreekbare polymeren.

Door drie van de deelnemende verwerkers wordt NK-concentraat geproduceerd. Gehalten daarin aan stikstof variëren van 5,6 tot $8,0 \mathrm{~g} \mathrm{~N} / \mathrm{kg}$ en deze stikstof is voor $>90 \%$ aanwezig in de vorm van ammonium $\left(\mathrm{N}-\mathrm{NH}_{4}\right)$. Gehalten aan zwavel $(\mathrm{S})$ variëren van 1,6 tot $5,4 \mathrm{~g} \mathrm{~S} / \mathrm{kg}$ door verschillen in toevoeging van zwavelzuur (omgekeerde osmose) en ijzersulfaat (fosfaatverwijdering). Hoge zwavelgehalten in NK-concentraat zijn een aandachtspunt omdat dit, bij bemesting op basis van de gewasbehoefte voor stikstof, leidt tot een zwavelgift die hoger is dan de gewasopname. Dat kan leiden tot een lagere gewasopname van sporenelementen en tot uitspoeling van sulfaat naar het grond- en oppervlaktewater. Mengen van zwavelhoudend NK-concentraat met drijfmest, voorafgaand aan opslag, wordt afgeraden vanwege risico's op vorming en emissies van het giftige mestgas waterstofsulfide $\left(\mathrm{H}_{2} \mathrm{~S}\right)$. Een hoog zwavelgehalte in de fosfaatarme bodemverbeteraar van GZV is ook een aandachtspunt; dit is te verlagen door een extra spoelstap. Het vermijden van milieubezwaarlijke chemie in de productie van herwonnen meststoffen vertaalt zich echter niet in een hogere marktwaarde. Beleid kan hierin richting geven, bijvoorbeeld door bij het vaststellen van een bovengrens voor het fosfaatgehalte in RENURE-materialen rekening te houden met de haalbaarheid hiervan zonder toevoeging van chemie. Ook het verruimen van mogelijkheden tot blenden van NKconcentraat met andere stikstofmeststoffen draagt bij aan de ontwikkelmogelijkheden van bemestingsproducten op maat. 
Hoofdstuk 6 bevat een kostenberekening voor drie mestverwerkingsscenario's:

A Scheiding van varkensdrijfmest in een dikke fractie en dunne fractie;

B Scheiding van varkensdrijfmest in een dikke fractie, NK-concentraat en loosbaar water;

C Scheiding van co-vergiste varkensdrijfmest in een dikke fractie, NK-concentraat, reststroom en loosbaar water.

Voor deze scenario's is de kostprijs per ton mest (A, B) of digestaat (C) berekend op basis van prijsniveaus voor 2021, inclusief kosten voor afschrijving, onderhoud, personeel, afzet van mestproducten, chemieverbruik, elektriciteitsverbruik en energieverbruik voor hygiënisatie. De kostprijs voor scheiding van varkensdrijfmest in exportwaardige dikke fractie en dunne fractie is berekend op $€ 19$ per ton bij afzet van dunne fractie in de regio ( $<50 \mathrm{~km}$ ) en op $€ 23$ euro per ton bij afzet van dunne fractie over $150 \mathrm{~km}$. Voor scheiding van mest tot een dikke fractie en NK-concentraat is de kostprijs berekend op $€ 20$ per ton drijfmest. Opwerking van dunne fractie tot NK-concentraat geeft daarmee een financieel voordeel ten opzichte van afzet van dunne fractie, tenzij de dunne fractie op relatief korte afstand van de verwerker afgezet kan worden. De kostprijs voor verwerking van codigestaat is berekend op $€ 21,50$ per ton digestaat, maar dit kan echter binnen dit project niet vertaald worden naar een kostprijs per ton mest omdat de businesscase van de biogasinstallatie niet in beeld is gebracht. Bij hoogwaardige mestverwerking, waaronder productie van NK-concentraat, bestaat het poorttarief voor circa $50 \%$ uit operationele en afschrijvingskosten. Hierdoor kan het poorttarief niet of maar beperkt mee dalen bij een dalend mestaanbod op de markt. Op dit moment wordt het aanbod van mest aan verwerkers gestuurd door de mestverwerkingsplicht, die is gekoppeld aan het fosfaatoverschot. Bij een dalend fosfaatoverschot zal het mestaanbod aan verwerkers dalen, omdat mestverwerking niet kan concurreren met directe afzet van drijfmest op de binnenlandse markt. Bij een verdere uitwerking van plannen voor verplichte verwerking van alle mest (tweesporenbeleid) in Nederland, moet daarom ook aandacht zijn voor de financiële haalbaarheid van deze plannen, bijvoorbeeld door ook andere maatschappelijke voordelen van mestverwerking financieel te belonen.

Huidige mestverwerkingsinstallaties zijn ontwikkeld met het doel om overschotten aan fosfaat op een zo gunstig mogelijke manier te verwerken. In de afgelopen vier jaar is de politieke aandacht voor mest verschoven van fosfaatverwerking naar het terugdringen van emissies van ammoniak (stikstofdepositie op kwetsbare natuur) en het behalen van klimaatdoelen (emissies van koolstofdioxide, methaan). Hoofdstuk 7 bevat een evaluatie over de effecten van verwerking van mest en co-vergiste mest op emissies van broeikasgassen en ammoniak. Qua broeikasgasemissies is het grootste voordeel te behalen door het verminderen van methaanemissies uit mestopslagen.

Mestverwerking kan daaraan bijdragen door de mest maandelijks of nog sneller bij de veehouder op te halen, gevolgd door scheiding in dikke en dunne fractie en/of vergisting. Scheiding van mest of covergiste mest in een dikke en dunne fractie geeft een lagere $\mathrm{CO}_{2}$-voetafdruk ten opzichte van een scenario met export van drijfmest over $250 \mathrm{~km}$. Ook bij opwerking tot NK-concentraat geldt dat de besparing op transport, doordat de meststof in de regio kan worden afgezet, opweegt tegen het extra energieverbruik. NK-concentraten kennen een hoog ammoniumgehalte en een hoge $\mathrm{pH}$-waarde $(>7,5)$ waardoor emissiearme aanwending is vereist. Aanwendingsemissies van ammoniak worden verondersteld lager te zijn voor NK-concentraat dan voor drijfmest vanwege een snellere infiltratie van NK-concentraat in de bodem, en gelijk aan of hoger dan voor stikstofkunstmest zoals

kalkammonsalpeter (KAS). De bijdrage van mestscheiding en verdere opwerking tot NK-concentraat aan het terugdringen van ammoniakemissies is naar verwachting bescheiden en hangt af van welke meststof (drijfmest of KAS) door NK-concentraat wordt vervangen.

Hoofdstuk 8 gaat in op de trends in de fosfaat- en stikstofbalans voor dierlijke mest in Nederland. In de periode 2015-2019 is de totale jaarlijkse fosfaatuitscheiding van varkens en runderen gedaald met respectievelijk 8,2\% (3,3 $\mathrm{mln}$. $\mathrm{kg} \mathrm{P}_{2} \mathrm{O}_{5}$ ) en $15 \%$ (16 mln. $\mathrm{kg} \mathrm{P}_{2} \mathrm{O}_{5}$ ). Voor varkens komt dit door opkoopmaatregelen die geleid hebben tot krimp van het totaalaantal dieren. Voor runderen komt dit door lagere fosforgehalten in ruwvoer. Gelijktijdig is de onderbenutting van de fosfaatgebruiksruimte op rundveebedrijven toegenomen door een aanhoudende stijging in de verhouding N/P in de drijfmestmest, waardoor de gebruiksnorm voor stikstof in meer gevallen het gebruik beperkt. In 2019 werd circa $40 \%$ van het fosfaat en circa $20 \%$ van de stikstof uit varkensmest buiten de Nederlandse landbouw afgezet; dit betrof het mestoverschot dat niet geplaatst kon worden binnen de 
gebruiksnormen. Opwerking van varkensdrijfmest tot NK-concentraat vermindert het kunstmestverbruik in de regio van toepassing. Op nationale schaal zal het stikstofkunstmestverbruik echter weinig afnemen, omdat het overgrote deel van de stikstof uit varkensmest al in de Nederlandse landbouw benut wordt in de vorm van drijfmest of dunne fractie.

Dit rapport sluit af met een synthese en aanbevelingen over mestverwerking en de milieuvoordelen daarvan. Mestverwerking is ontstaan als oplossing voor het overschot aan mest - hoofdzakelijk een overschot aan fosfaat - binnen de Nederlandse landbouw. In de laatste jaren is de aandacht voor mestverwerking in het kader van de transitie naar kringlooplandbouw en als oplossing voor andere maatschappelijke problemen, waaronder emissies van broeikasgassen en ammoniak, toegenomen. Ten dele zijn deze doelen complementair; zo kan hoogwaardige mestverwerking bijdragen aan het terugdringen van methaanemissies uit mestkelders door de mest maandelijks (of nog sneller) bij de veehouder op te halen. Qua ammoniakemissies naar de lucht is de situatie complexer. NK-concentraat kent een hoge $\mathrm{pH}$ en een hoog gehalte aan ammonium en is daardoor emissiegevoelig. Op basis van de huidige kennis is de ammoniakemissie bij gebruik van NK-concentraat op bouwland gelijk aan die van KAS-kunstmest, omdat NK-concentraat op bouwland diep geïnjecteerd wordt. Op grasland is de ammoniakemissie bij gebruik van NK-concentraat lager dan bij gebruik van drijfmest, maar hoger ten opzichte van KAS-kunstmest. Omdat het fosfaatoverschot binnen de Nederlandse landbouw dalende is - en de verplichting tot mestverwerking gebaseerd is op de hoogte van het fosfaatoverschot -, is een andere vorm van stimulering of verplichting van mestverwerking gewenst, waarbij ook andere milieuvoordelen van mestverwerking beloond worden, zoals emissiereductie van broeikasgassen en ammoniak. Verdere ontwikkeling van innovaties in de verwerking van mest of co-vergiste mest vraagt daarnaast om zekerheid in termen van het toekomstige aanbod van mest en om wet- en regelgeving die hierop inspeelt. 


\section{$1 \quad$ Inleiding}

\subsection{Mestbeleid en kringlooplandbouw}

De Nederlandse landbouwsector staat wereldwijd bekend als hoogproductief en zeer efficiënt en Nederland is na de Verenigde Staten de grootste exporteur van landbouwproducten. De hoge intensiteit van de Nederlandse veehouderij heeft echter negatieve keerzijden doordat verhoogde verliezen van nutriënten naar bodem, water en atmosfeer kunnen optreden.

Decennia van bemesting met fosfaatgiften hoger dan de gewasopname hebben geleid tot verhoogde fosfaattoestanden van de bodem en verhoogde risico's op uitspoeling van fosfaat $\left(\mathrm{P}_{2} \mathrm{O}_{5}\right)$ naar gronden oppervlaktewater en hebben daarmee bijgedragen aan eutrofiëring. Om kwaliteitsdoelstellingen voor oppervlaktewater te behalen, zijn er beperkingen opgelegd aan het gebruik van fosfaat. De fosfaatgebruiksnormen, ingevoerd in 1987, zijn sindsdien stapsgewijs verlaagd en zijn nu op het niveau van evenwichtsbemesting. Dit houdt in dat de fosfaatgebruiksnorm bij een neutrale fosfaattoestand van de bodem gelijk is aan de fosfaatafvoer via het gewas. Bemesting met dierlijke mest geeft risico's op verhoogde uitspoeling van zowel fosfaat als nitraat, wat naast eutrofiëring ook nadelig is voor de geschiktheid van grondwater voor productie van drinkwater. Maatregelen om grondwater te beschermen tegen uitspoeling van nitraat uit de landbouw zijn opgenomen in de Nitraatrichtlijn. Onderdeel hiervan is de gebruiksnorm dierlijke mest, die het gebruik van dierlijke mest beperkt tot $170 \mathrm{~kg}$ stikstof $(\mathrm{N}) / \mathrm{ha}$. Voor veehouders met graasdieren en een areaal met meer dan $80 \%$ grasland in 2021 is er de mogelijkheid om deel te nemen aan de derogatieregeling, waarbij de gebruiksnorm dierlijke mest 230 of $250 \mathrm{~kg} \mathrm{~N} /$ ha bedraagt, afhankelijk van de regio en de grondsoort. Door deze maatregelen is de aanvoer van fosfaat en stikstof naar Nederlandse landbouwgronden in 2018 met respectievelijk 49\% en 30\% gedaald ten opzichte van 1990. De omvang van de veestapel daalde ook, maar de totale uitscheiding van fosfaat en stikstof bleef hoger dan de plaatsingsruimte waardoor export van mest nodig was. Mestverwerking werd verplicht gesteld voor bedrijven die hun geproduceerde dierlijke mest, uitgedrukt in $\mathrm{kg} \mathrm{P}_{2} \mathrm{O}_{5}$, niet volledig kunnen plaatsen op eigen landbouwgrond gegeven de gestelde fosfaatgebruiksnormen.

Om voldoende mestverwerkingscapaciteit te realiseren, is in 2014 de verplichte mestverwerking ingevoerd. Dit als onderdeel van het beleid om het fosfaatoverschot op een verantwoorde manier buiten de Nederlandse landbouw af te zetten, grondgebondenheid van veebedrijven te stimuleren en mestfraude tegen te gaan. Niet-grondgebonden veehouders - waarbij de fosfaatuitscheiding hoger is dan de plaatsingsruimte binnen het bedrijf - zijn sindsdien verplicht om een deel van het bedrijfsoverschot aan fosfaat te laten verwerken. ${ }^{1}$ De veehouder kan voldoen aan de verwerkingsplicht door de mest te exporten, af te zetten naar een mestverwerker die het fosfaat afzet buiten de Nederlandse landbouw (drie-partijenovereenkomst) of door aankoop van vervangende verwerkingsovereenkomsten (VVO's). De door mestexcretie geproduceerde hoeveelheid fosfaat is leidend bij de verplichting tot mestverwerking. De verplichte mestverwerking - en daarnaast een plicht tot grondgebonden groei van de melkveestapel - werd ingevoerd als voorbereiding op de afschaffing van het melkquotum in 2015. De totale fosfaatuitscheiding van landbouwdieren steeg in 2015 door groei van de melkveehouderij na afschaffing van het melkquotum. Door de verplichte mestverwerking was een beperkte groei in principe toegestaan, echter in 2015 en 2016 overschreed Nederland het met de EU afgesproken fosfaatplafond van 172,9 miljoen kg fosfaat, wat als voorwaarde gold voor behoud van de derogatie. Na een verplichte krimp van de melkveestapel is in 2018 het fosfaatrechtenstelsel ingevoerd voor melkvee en zijn afspraken gemaakt om het fosfaatgehalte in krachtvoer voor melkvee te verlagen.

\footnotetext{
1 Het percentage te verwerken mest varieert per regio: in 2020 en 2021 bedraagt de verplichte mestverwerking in regio Zuid $52 \%$, in regio Oost $59 \%$ en in de overige regio's $10 \%$ van het bedrijfsoverschot aan fosfaat.
} 


\subsection{Kringlooplandbouw}

In 2018 heeft het ministerie van LNV onder minister Schouten de contouren geschetst voor een toekomstig landbouwsysteem op basis van gesloten kringlopen. ${ }^{2}$ De overgang naar kringlooplandbouw heeft gevolgen voor het gebruik van dierlijke mest en kunstmest en de verwerking en bewerking van dierlijke mest. In september 2020 heeft de minister van LNV de contouren voor een nieuw mestbeleid geschetst, waarin gestuurd wordt op volledige verplichte verwerking van mest van nietgrondgebonden bedrijven of afzet via langlopende contracten. ${ }^{3}$ De voornaamste doelen zijn het tegengaan van mestfraude en, door overbemesting te voorkomen, het behalen van de waterkwaliteitsdoelstellingen. Er zijn echter meer doelen in beeld. Mestverwerking kan bijdragen aan klimaatdoelstellingen door het terugdringen van methaanemissies uit mestopslagen. Ook kan mestverwerking een rol spelen in het verlagen van ammoniakemissies uit mest door het veranderen van de samenstelling of andere eigenschappen van de mest. De verplichte mestverwerking voor nietgrondgebonden bedrijven is door minister Schouten verder uitgewerkt in de 'routekaart toekomstig mestbeleid. ${ }^{4}$ Daarin wordt gesproken over stimulering van de productie van kunstmestvervangers (RENURE-materialen; REcovered Nitrogen from manURE). Een RENURE-materiaal bevat minimaal 90\% van de stikstof in de vorm van mineraal stikstof $\left(\mathrm{NH}_{4}\right.$ of $\left.\mathrm{NO}_{3}\right)$ of heeft op massabasis een verhouding TOC/N van maximaal 3,0, waardoor de stikstofwerkingscoëfficiënt gelijk is aan die van reguliere stikstofkunstmest. Dergelijke meststoffen zouden daarom in plaats van kunstmest - boven op de gebruiksnorm dierlijke mest - toegepast mogen worden. Op dit moment wordt het gebruik van RENURE-materialen nog niet gereguleerd door de Nitraatrichtlijn; het Europees beleidsproces ${ }^{5}$ hierover is nog gaande. Wel is er in Nederland een tijdelijke vrijstelling voor gebruik van stikstof-kalium (NK)concentraat als kunstmestvervanger voor een beperkt aantal bedrijven onder de pilot Mineralenconcentraat en onder de pilot Kunstmestvrije Achterhoek.

\subsection{Verwerkingscapaciteit en mestverwerkingstechnieken}

In 2019 waren er 37 bedrijven waar verwerking van varkensmest plaatsvond waarvan de gezamenlijke verwerkingscapaciteit voor varkensmest naar schatting 9 miljoen $\mathrm{kg} \mathrm{P}_{2} \mathrm{O}_{5}$ bedroeg (NCM, 2020). Deze bedrijven verwerken hoofdzakelijk varkensdrijfmest en een kleiner aandeel runderdrijfmest. (Daarnaast vindt verwerking plaats van kippenmest, maar dit is buiten beschouwing gelaten.) De verwerkingscapaciteit voor varkensmest is sindsdien toegenomen door de realisatie van nieuwe initiatieven, waaronder de mestverwerkingsinstallatie van Greenferm in Apeldoorn met een capaciteit van 350.000 ton mest per jaar en de in aanbouw zijnde mestverwerkingsinstallatie van Twence in Zenderen, met een capaciteit van 250.000 ton mest per jaar. Inclusief deze nieuwe installaties wordt de Nederlandse verwerkingscapaciteit voor drijfmest geschat op circa 11,1 miljoen $\mathrm{kg} \mathrm{P}_{2} \mathrm{O}_{5}$ per jaar. In 2019 bedroeg de totale afzet van fosfaat uit varkensmest buiten de Nederlandse landbouw circa 17 miljoen $\mathrm{kg} \mathrm{P}_{2} \mathrm{O}_{5}{ }^{6}$, inclusief export van drijfmest. Hiervan werd 9 miljoen $\mathrm{kg} \mathrm{P}_{2} \mathrm{O}_{5}$ geëxporteerd in de vorm van dikke fractie. Wanneer alle nog te bouwen en in aanbouw zijnde installaties in gebruik zijn, is de totale verwerkingscapaciteit nagenoeg toereikend om circa $65 \%$ van het fosfaatoverschot aan varkensmest te kunnen verwerken, uitgaande van een gelijkblijvende fosfaatuitscheiding. De definitie van verwerken is hierbij gelijk aan de wettelijke definitie. Dat wil zeggen dat installaties die vergiste en/of gehygiëniseerde varkensdrijfmest zonder verdere vorm van scheiding afzetten buiten de Nederlandse landbouw, ook onder bovengenoemde verwerkingscapaciteit vallen.

Voor verwerking van mest worden verschillende technieken toegepast. Het NCM heeft een overzicht gerapporteerd van toegepaste technieken op basis van enquêtes onder de leden (NCM, 2020). De resultaten zijn gepresenteerd in termen van aantallen bedrijven die een bepaalde techniek toepassen. Dit is niet om te rekenen naar totale verwerkingscapaciteit per verwerkingstechniek. Voor scheiding

\footnotetext{
2 Visie Landbouw, Natuur en Voedsel: Waardevol en Verbonden, beleidsnota, 8 september 2018

3 Contouren toekomstig mestbeleid, kamerbrief, 8 september 2020, DGA-PAV/20230798

4 Routekaart toekomstig mestbeleid, kamerbrief, 14 april 2021, DGA-PAV/21066300

5 Dagtekening juli 2021

6 Export, verwerking en afzet naar natuur- en hobbyterreinen. Bron: INITIATOR-model (hoofdstuk 8)
} 
van mest of digestaat in een dikke en dunne fractie worden de decanter centrifuge en zeefbandpers genoemd. Voor verdere behandeling van die dikke fractie worden technieken als biologisch drogen, thermisch drogen, composteren en/of pelletiseren of verbranding genoemd. De geproduceerde dunne fractie wordt grotendeels zonder verdere verwerking afgezet binnen de Nederlandse landbouw. In 2019 bedroeg de productie van NK-concentraat (ook wel mineralenconcentraat genoemd) circa 400.000 ton $(2,5 \mathrm{mln}$. $\mathrm{kg} \mathrm{N})(\mathrm{NCM}, 2020)$. Biologische behandeling van de dunne fractie, waarbij stikstof door nitrificatie-denitrificatie wordt omgezet in onschadelijk stikstofgas, wordt in Nederland maar beperkt toegepast (NCM, 2020). Dit in tegenstellig tot Vlaanderen, waar biologische behandeling van de dunne fractie van mest de meest voorkomende verwerkingstechniek is. ${ }^{7}$ Dit is het gevolg van het feit dat in Vlaanderen de mestverwerking is ingeregeld op het stikstofoverschot en niet op het fosfaatoverschot. Met de ingebruikname van de installatie van Twence wordt, met de productie van ammoniakwater ten behoeve van rookgasreiniging, een nieuw proces aan de lijst van verwerkingstechnieken in Nederland toegevoegd.

In aanvulling op reguliere mestverwerking wordt door het bedrijfsleven en kennisinstellingen ook gezocht naar nieuwe vormen van mestverwerking waaronder het scheiden van fosfaat en organische stof uit de dikke fractie. Een techniek hiervoor - genaamd RePeat (Recovery of P to eat) - is in een voorafgaand TKI-project van laboratorium- tot pilotschaal ontwikkeld (Schoumans et al., 2017; Regelink et al., 2019). Dikke fractie van co-vergiste mest (digestaat) wordt door behandeling met proceswater en zuur ontdaan van fosfaat, waarna het geschikt is voor lokaal gebruik als bodemverbeteraar. Gaandeweg zijn ook hoogwaardigere toepassingen in beeld gekomen, waaronder afzet als veenvervanger in afdekaarde van substraat voor champignonteelt of afzet als veenvervanger in potgrond. Fosfaat wordt in dit proces met kalkmelk neergeslagen in de vorm van slib met hoge gehalten aan calcium, fosfaat en zwavel. Dergelijke nieuwe ontwikkelingen, waarbij mest wordt verwerkt tot producten met een positieve afzetwaarde, zijn van belang om mestverwerking in de toekomst rendabel te houden.

\subsection{Doelstelling en aanpak}

Dit rapport bevat de uitkomsten van de monitoring en evaluatie van vijf grootschalige installaties voor de verwerking van varkensdrijfmest of co-vergiste varkensdrijfmest. Dit onderscheid tussen verwerking met en zonder co-vergisting is gemaakt vanwege het verschil in samenstelling tussen varkensdrijfmest en het digestaat dat ontstaat bij co-vergisting van varkensdrijfmest. De hier uitgevoerde analyse is voortgekomen vanuit de behoefte van de deelnemende bedrijven om onderling kennis te delen over o.a. scheidingsrendementen, procesvoering en verwerkingskosten en -baten.

Dit leidde tot de volgende doelstelling:

Beoordeling en vergelijking van grootschalige installaties voor de verwerking van varkensdrijfmest of co-vergiste varkensdrijfmest in termen van scheidingsrendementen, massabalansen, verbruik aan chemie en energie, agronomische en milieukundige productkwaliteit, emissies van broeikasgassen en ammoniak en verwerkingskosten en -baten.

\subsection{Leeswijzer}

Dit rapport bevat de uitkomsten van de monitoring en evaluatie van vijf grootschalige installaties voor de verwerking van varkensmest of co-vergiste varkensmest. Dit betreft de installaties van Groot Zevert Vergisting (Beltrum), Merensteyn (Ysselsteyn), Maatschap Van Amstel (Lith), Loonbedrijf Dekker (Putten) en Ecoson (Son). Voor Groot Zevert Vergisting is een uitgebreidere monitoring uitgevoerd en tevens de monitoring van het RePeat-systeem voor scheiding van de dikke fractie van digestaat in een bodemverbeteraar en fosfaatmeststof opgenomen. Het rapport gaat in op behaalde scheidingsrendementen, massabalansen en chemie- en energieverbruik van bovengenoemde

\footnotetext{
7 https://www.vcm-mestverwerking.be/nl/kenniscentrum/177/mestverwerking-in-vlaanderen
} 
mestverwerkingsinstallaties (hoofdstuk 3). Additioneel onderzoek naar scheiding van kalium en stikstof is opgenomen in hoofdstuk 4 . Hoofdstuk 5 geeft een vergelijking en beoordeling van de mestproducten geproduceerd door de deelnemende mestverwerkers. De berekende en door de verwerkers gedeelde gegevens zijn vervolgens gebruikt voor het afleiden van de kosten en baten van de installaties (hoofdstuk 6) en de effecten op de uitstoot aan broeikasgassen (hoofdstuk 7).

Hoofdstuk 8 gaat in op de stikstof- en fosfaatbalans van de Nederlandse landbouw en de trends daarin over de periode 2015-2019. Hoofdstuk 9 sluit af met een synthese en een vooruitblik op de perspectieven voor mestverwerking bij een veranderende mestproductie. 


\section{Materiaal en Methoden}

\subsection{Mest- en digestaatverwerkers}

Tabel 2.1 geeft een algemeen overzicht van de zes deelnemende bedrijven waar varkensdrijfmest of co-vergiste varkensdrijfmest wordt verwerkt. Voor alle locaties met uitzondering van Twence, zijn in dit rapport massabalansen opgesteld. De mestverwerkingsinstallatie van Twence was ten tijde van schrijven nog niet operationeel.

Tabel 2.1 Overzicht van de algemene kenmerken, scheidingstechnieken en eindproducten van de zes aan het project deelnemende mestverwerkingsinstallaties. ${ }^{1}$

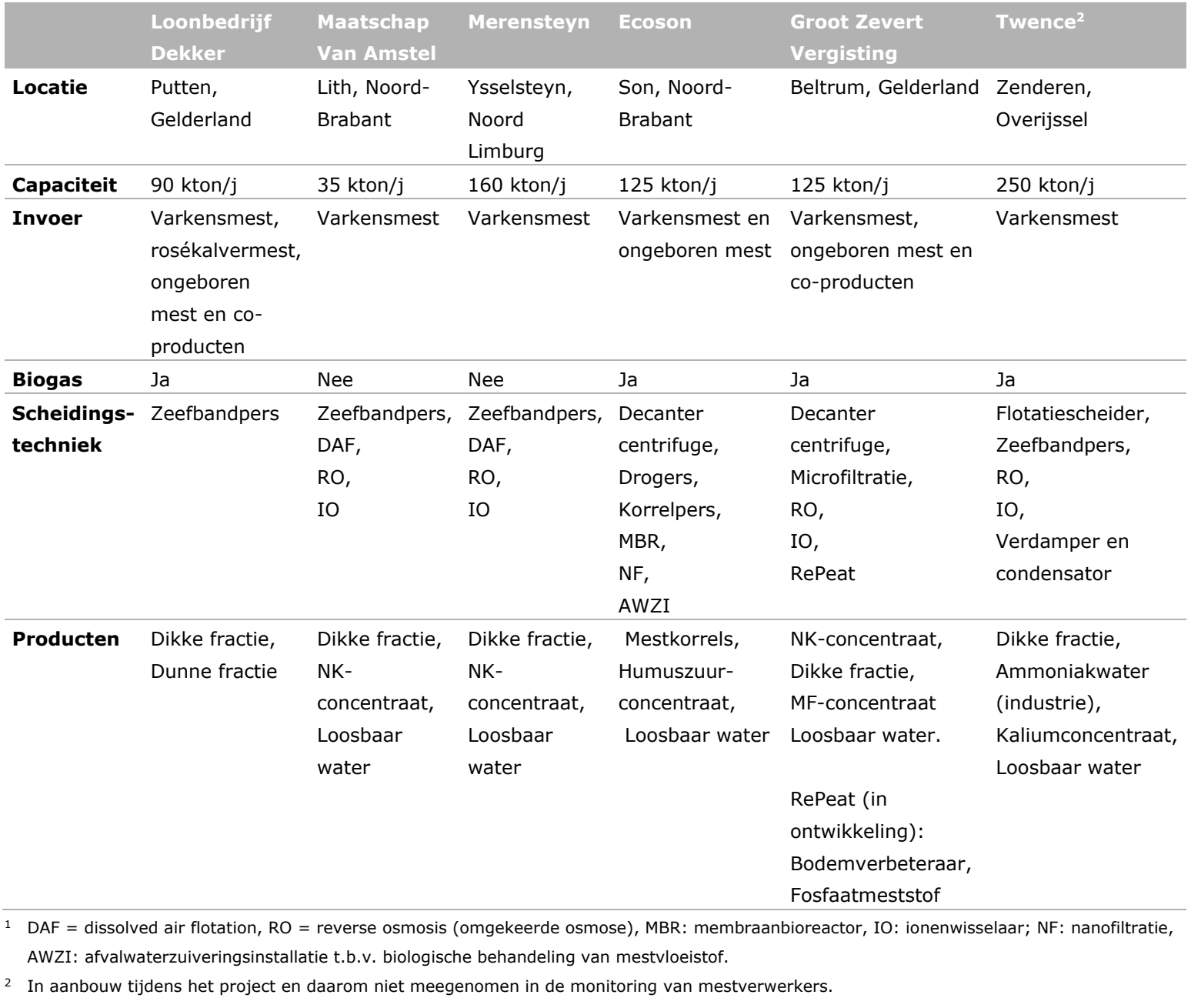




\subsection{Bemonstering en chemische analyse van monsters}

Bemonstering van de verwerkingsinstallaties Tabel 2.2 toont een overzicht van de uitgevoerde bemonsteringsrondes bij de mest- en digestaatverwerkingsinstallaties en eventuele gemeten debieten van processtromen. Het GENIAAL-systeem van Groot Zevert Vergisting (GZV) gericht op stikstof- en kaliumherwinning door bewerking van de dunne fractie wordt sinds begin 2019 door Wageningen Environmental Research (WENR) gemonitord voor het H2020-project SYSTEMIC. De bemonstering daarvoor was minimaal driemaandelijks, meestal frequenter. Vanaf juli 2020 werd ook het RePeatsysteem gericht op separate herwinning van fosfaat en organisch stof gemonitord en met regelmaat bemonsterd. Loonbedrijf Dekker (hierna Dekker), Maatschap Van Amstel (hierna Van Amstel) en Merensteyn zijn door WENR respectievelijk 2, 3 en 3 keer bemonsterd. Ecoson is door haar eigen medewerkers bemonsterd waarna de uitkomsten van de chemische analyse daarvan zijn gedeeld met WENR.

Monsters zijn genomen van alle in- en uitgaande stromen van de individuele scheidingsapparaten inclusief eventuele retourstromen. Schema's met de locatie van de bemonsteringspunten per verwerkingsinstallatie zijn opgenomen in hoofdstuk 3. De monsters van één bemonsteringsronde zijn genomen binnen een tijdsbestek van circa 1 à 2 uren. Bij monstername uit aftapkraantjes is het kraantje eerst vijf seconden doorgespoeld alvorens te bemonsteren. Monsterflessen zijn zo snel mogelijk afgesloten om vervluchtiging en daardoor verlies van gassen zo klein mogelijk te houden. Bij monstername uit tanks die open zijn aan de bovenkant is de monsterfles in zijn geheel ondergedompeld in de vloeistof en is erop gelet dat een eventuele dunne drijflaag niet bovenproportioneel werd meegenomen in het monster. Vloeibare (proces)stromen zijn bemonsterd in $1 \mathrm{~L}$ polyethyleen monsterflessen die voor circa twee derde werden gevuld. Vaste (proces)stromen zijn bemonsterd in polyethyleen monsterflessen of in plastic zakken. Deze monsters van vloeibare en vaste (proces)stromen werden binnen twee dagen afgeleverd bij een van de ophaalpunten van het laboratorium 'Landwirtschaftliche Untersuchungs- und Forschungsanstalt Nordrhein-Westfalen' (LUFA NRW). Binnen drie weken na monstername werden deze monsters chemisch geanalyseerd in hun laboratorium in Münster (Duitsland) en voor het merendeel van die tijd gekoeld bewaard.

Watermonsters stroomafwaarts van de omgekeerde osmose (reverse osmosis (RO))-installaties werden bij voorkeur bemonsterd in $100 \mathrm{ml}$ glazen monsterflesjes met gasdichte ring in de dop om eventuele vervluchtiging van gassen te minimaliseren. Indien deze glazen flesjes niet voorradig waren, is bemonsterd in $1 \mathrm{~L}$ monsterflessen van polyetheen. Beide typen flessen zijn zo compleet mogelijk gevuld om de 'headspace' zo klein mogelijk te houden. Dit om verliezen van gassen zoals ammoniak $\left(\mathrm{NH}_{3}\right)$ en waterstofsulfide $\left(\mathrm{H}_{2} \mathrm{~S}\right)$ uit het monster zo klein mogelijk te houden. Eerdere testen wezen uit dat de watermonsters stroomafwaarts van de RO's van GZV hoge concentraties $\mathrm{H}_{2} \mathrm{~S}$ kunnen bevatten. Watermonsters zijn binnen twee maanden na monstername chemische geanalyseerd door het Chemisch Biologisch Laboratorium Bodem (CBLB), onderdeel van Wageningen UR, en tot die tijd eerst bewaard bij $4^{\circ} \mathrm{C}$ en maximaal enkele weken vlak voor de analyse bij $20^{\circ} \mathrm{C}$. 
Tabel 2.2 Overzicht data van bemonsteringsrondes en beschikbaarheid van gemeten debieten van de mest- en digestaatverwerkingsinstallaties.

\begin{tabular}{|c|c|c|}
\hline & Data van bemonsteringsrondes & Continue debietmeters \\
\hline $\begin{array}{l}\text { Groot } \\
\text { Zevert } \\
\text { Vergisting - } \\
\text { GENIAAL }\end{array}$ & $\begin{array}{l}2020-01-29 \\
2020-03-30 \\
2020-06-17 \\
2020-09-17 \\
2020-10-26 \\
2020-12-08 \\
2021-01-12 \\
2021-02-10\end{array}$ & $\begin{array}{l}\text { Gemeten debieten van de in- en uitgaande stromen van de } \\
\text { scheidingsapparaten zijn beschikbaar vanaf januari } 2020 \text {. } \\
\text { Additionele debieten van interne retourstromen zoals } \\
\text { spoelwater e.d. is beschikbaar vanaf september } 2020 \text {. } \\
\text { Massabalans is opgesteld over de bemonsteringsrondes van } \\
\text { september } 2020 \mathrm{t} / \mathrm{m} \text { februari } 2021(n=5) \text {. }\end{array}$ \\
\hline $\begin{array}{l}\text { Groot } \\
\text { Zevert } \\
\text { Vergisting - } \\
\text { RePeat }\end{array}$ & $\begin{array}{l}2020-05-11 \\
2020-07-22 \\
2020-09-17 \\
2020-10-29 \\
2021-01-13 \\
2021-04-23\end{array}$ & $\begin{array}{l}\text { Gemeten debieten van de in- en uitgaande stromen van de } \\
\text { scheidingsapparaten zijn beschikbaar vanaf november } 2020 \text {. } \\
\text { Massabalans is opgesteld voor de bemonsteringsronde van 23- } \\
04-2021(n=1) \text {. }\end{array}$ \\
\hline $\begin{array}{l}\text { Loonbedrijf } \\
\text { Dekker }\end{array}$ & $\begin{array}{l}2019-11-18 \\
2020-01-22\end{array}$ & $\begin{array}{l}\text { Geen debietmeters. Massabalans is opgesteld over beide } \\
\text { bemonsteringsrondes }(n=2) \text {. }\end{array}$ \\
\hline $\begin{array}{l}\text { Maatschap } \\
\text { Van Amstel }\end{array}$ & $\begin{array}{l}2019-11-19 \\
2020-01-23 \\
2020-11-06\end{array}$ & $\begin{array}{l}\text { Geen debietmeters. Massabalans is opgesteld over deze drie } \\
\text { bemonsteringsrondes }(n=3) \text {. }\end{array}$ \\
\hline Merensteyn & $\begin{array}{l}2019-11-20 \\
2020-01-23 \\
2020-11-03\end{array}$ & $\begin{array}{l}\text { Geen debietmeters. Massabalans is opgesteld over deze drie } \\
\text { bemonsteringsrondes }(n=3) \text {. }\end{array}$ \\
\hline
\end{tabular}

\subsubsection{Chemische analyses van de monsters}

Voor het aanvragen van de chemische analyses bij LUFA NRW zijn hun orderformulieren voor 'Wirtschaftsdünger' gebruikt. Het drogestofgehalte is bepaald als het gewichtsverlies na drogen van de monsters bij $105^{\circ} \mathrm{C}$ gedurende 24 uur. Het organischestofgehalte is bepaald als het gewichtsverlies na oxidatie bij $550^{\circ} \mathrm{C}$. Totaalgehalten van P (fosfor), Ca (calcium), Mg (magnesium), $\mathrm{K}$ (kalium), $\mathrm{S}$ (zwavel) en Fe (ijzer) zijn bepaald na destructie met aqua regia (twee uur koken met een mengsel van geconcentreerd zoutzuur en geconcentreerd salpeterzuur). Voor vloeibare monsters is de destructie uitgevoerd op het verse monstermateriaal, voor vaste monsters is de destructie uitgevoerd op het gedroogde monster. Het supernatant van de destructie wordt, na filtratie over een papierfilter, geanalyseerd met Inductively Coupled Plasma Optical Emission Spectrometry (ICP-OES). Indien sulfides in het monster aanwezig zijn, geeft deze methode een onderschatting van het totaal-Sgehalte door vervluchtiging van $\mathrm{H}_{2} \mathrm{~S}$, veroorzaakt door de toevoeging van zuur tijdens de destructie.

Voor vloeibare monsters is $\mathrm{N}$ bepaald na 'dry combustion' (droge verbranding) op een elemental analyser zonder voorafgaand drogen. In de vaste monsters is $\mathrm{N}$ gemeten met de Kjeldahl-methode. Ammonium $\left(\mathrm{N}-\mathrm{NH}_{4}\right)$ is bepaald door soda $\left(\mathrm{Na}_{2} \mathrm{CO}_{3}\right)$ toe te voegen gevolgd door destillatie waarna $\mathrm{NH}_{3}$ wordt opgevangen in zuur en de hoeveelheid ervan met titratie wordt bepaald. Totaal organisch koolstof (TOC) is bepaald na droge verbranding in een $\mathrm{CN}$-analyzer. De elektrische geleidbaarheid (electrical conductivity, EC) is bepaald na toevoeging van 300 gram demiwater aan 30 gram monsters gevolgd door schudden en filtratie, waarna de EC is bepaald in het filtraat. Deze door LUFA NRW gerapporteerde EC is door WENR gecorrigeerd voor deze verdunning door de meetwaarde maal 11 toe te passen.

Watermonsters van het permeaat van de RO's en stromen stroomafwaarts daarvan zijn geanalyseerd door het CBLB in Wageningen. De monsterflessen werden zo kort mogelijk geopend en de monsters werden niet aangezuurd voorafgaand aan de chemische analyse. Ortho-fosfaat $\left(\mathrm{P}-\mathrm{PO}_{4}\right), \mathrm{N}$, ammonium $\left(\mathrm{N}-\mathrm{NH}_{4}\right)$ en nitraat $\left(\mathrm{N}-\mathrm{NO}_{3}\right)$, chloride, sulfaat $\left(\mathrm{S}-\mathrm{SO}_{4}\right)$ en opgelost organisch koolstof (DOC) zijn spectrofotometrisch bepaald met een segmented flow analyser. Totale concentraties aan $\mathrm{P}, \mathrm{K}, \mathrm{Ca}, \mathrm{Mg}, \mathrm{S}$, $\mathrm{Na}$ (natrium), Fe, Al (aluminium), Cu (koper), Zn (zink) en Mn (mangaan) zijn bepaald met ICP-OES. 
Indien in een eindproduct de concentratie voor een component voor sommige monsters boven, en voor andere monsters onder, de kwantificeringslimiet (limit of quantification, LOQ) voor de gebruikte chemische analysemethode lag, is daar als volgt mee omgegaan. Voor berekening van de gemiddelde concentratie over al deze monsters is voor concentraties < LOQ de waarde LOQ/ $\sqrt{2}$ gehanteerd.

\subsubsection{Verzameling overige informatie}

Verdere informatie over o.a. het energie- en chemieverbruik, de transportafstanden voor de afzet van eindproducten en algemene informatie over de werking van de scheidingsapparaten zijn verkregen via een enquête, via e-mails en via mondeling contact tijdens de bemonsteringsrondes en per telefoon. De enquête is door de vertegenwoordiger van de verwerkingsinstallatie en vervolgens tijdens een bedrijfsbezoek mondeling besproken.

\subsection{Berekening van scheidingsrendementen en massabalansen}

\subsubsection{Loonbedrijf Dekker, Maatschap Van Amstel en Merensteyn}

Voor de verwerkingsinstallaties die WENR heeft bemonsterd en waar geen debietmeters aanwezig waren (Dekker, Van Amstel en Merensteyn), zijn de scheidingsrendementen en massabalansen via de volgende methode berekend:

Per scheidingsstap is de totale massa van de ingaande en uitgaande stromen berekend als:

$\%$ van de totale massa naar dikke fractie $=100 \% *\left(\frac{m_{s f}}{m_{i n}}\right)=100 \% *\left(\frac{w_{D S, i n}-w_{D S, l f}}{w_{D S, s f}-w_{D S, l f}}\right) \quad$ (vergelijking 1$)$

$\%$ van de totale massa naar dunne fractie $=100 *\left(1-\left(\frac{m_{s f}}{m_{\text {in }}}\right)\right) \quad$ (vergelijking 2)

Waarin:

$m_{\text {in }}=$ totale massa van de ingaande stroom in $\mathrm{kg}$;

$m_{s f}=$ totale massa van de dikke fractie (solid fraction) in $\mathrm{kg}$;

$m_{l f}=$ totale massa van de dunne fractie (liquid fraction) in $\mathrm{kg}$;

$w_{D S, i n}, w_{D S, l f}, w_{D S, s f}=$ het drogestofgehalte $(D S)$ in respectievelijk de ingaande stroom, dikke fractie en dunne fractie in $\mathrm{g} / \mathrm{kg}$.

Vergelijking 1 en 2 zijn in feite de berekening van de scheidingsrendementen voor de totale massa naar de dikke en naar de dunne fractie.

Voor RO's en ionenwisselaars is in vergelijking 1 en 2 het kaliumgehalte gebruikt in plaats van het drogestofgehalte, omdat de stromen rondom die apparaten weinig tot geen droge stof meer bevatten. Het scheidingsrendement is voor die stromen daarom nauwkeuriger af te leiden op basis van het kaliumgehalte, mede omdat kalium niet vluchtig is.

Omdat in de chemische analyses is vastgesteld dat de dichtheid van alle vloeibare stromen praktisch gelijk is aan $1000 \mathrm{~kg} / \mathrm{m}^{3}$, is de totale massa gelijk aan het volume (m.u.v. dikke fracties).

$\mathrm{Na}$ berekening van de scheidingsrendementen voor de totale massa, kunnen de scheidingsrendementen per component (droge stof, organische stof, stikstof, fosfaat, kalium etc.) berekend worden met vergelijking 3 en 4 . 
Waarin:

$w_{i, \text { in }}=$ het gehalte van component $i$ in de ingaande stroom in $\mathrm{g} / \mathrm{kg}$;

$w_{i, s f}=$ het gehalte van component $i$ in de dikke fractie in $\mathrm{g} / \mathrm{kg}$;

$w_{i, l f}=$ het gehalte van component $i$ in de dunne fractie in $\mathrm{g} / \mathrm{kg}$.

Voor elk scheidingsapparaat zijn $w_{i, i n}, w_{i, s f}$ en $w_{i, l f}$ bekend door chemische analyse van de genomen monsters. Indien het berekende scheidingsrendement over een papierfilter voor bepaalde componenten negatief was en de concentratie erna hoger was dan ervoor, dan is als scheidingsrendement $0 \%$ gehanteerd voor die componenten.

Bij een aantal scheidingsapparaten werd stroomafwaarts van het bemonsteringspunt chemie ( $\mathrm{Fe}_{2}\left(\mathrm{SO}_{4}\right)_{3}$-oplossing, zwavelzuur of polymeeroplossing) toegevoegd. Zowel de totale massa als de samenstelling van die stromen zijn hiervoor gecorrigeerd op basis van door de verwerker opgegeven chemiedoseringen, waarbij rekening is gehouden met de dichtheid van de toegevoegde chemie. Dit zijn qua volume en massa veelal relatief kleine toevoegingen $(<10 \%)$. De zwavelzuurdosering was niet bij alle verwerkers nauwkeurig bekend en is in die gevallen berekend aan de hand van de toename in zwavelmassa in de uitgaande stromen versus de ingaande stroom van het betreffende scheidingsapparaat. Van de toegevoegde polymeervloeistoffen was de samenstelling niet bekend en is alleen de door toevoeging veroorzaakte verdunning meegenomen in de berekeningen.

Met bovenstaande sets van vergelijkingen is voor iedere component het scheidingsrendement afgeleid. Omdat de scheidingsrendementen voor de totale massa zijn berekend op basis van het drogestofgehalte is de massabalans voor drogestof per definitie kloppend; de som van de uitgaande stromen is per scheidingsapparaat exact gelijk aan die van de ingaande stromen. Voor de andere componenten kan de som van de uitgaande stromen afwijken van die van de ingaande stromen door onnauwkeurigheden. De mate van afwijking hierin wordt besproken bij de resultaten in hoofdstuk 3 .

Om tot de massabalans van de gehele installatie te komen, moeten ook eventuele retourstromen zoals slib van de Dissolved Air Flotation (DAF), spoelwater en als chemie toegevoegd oploswater worden meegenomen. Het startpunt is de gemeten samenstelling van de ingaande mest of het ingaande digestaat op de zeefbandpers, waarna met de scheidingsrendementen voor de zeefbandpers de scheiding naar de dikke en dunne fractie is berekend. De berekende massa's in de dunne fractie zijn vervolgens het uitgangspunt voor de berekening van de massabalans over de DAF (indien aanwezig). Het slib van de DAF wordt teruggevoerd naar een mengtank voor de zeefbandpers; dit is als iteratieve berekening meegenomen. De berekende samenstelling van het effluent van de DAF is vervolgens gebruikt voor berekening van de scheiding door de papierfilters, waarbij wederom eventuele retourstromen of toevoeging van spoelwater zijn meegenomen. De berekende samenstelling van het effluent daarvan is weer gebruikt voor berekening van de scheiding door de RO.

De factor waarmee een RO het gehalte van een component ' $i$ ' in het concentraat verhoogt ten opzichte van het influent (de concentratiefactor) is berekend met vergelijking 6 .

Concentratiefactor $R O=\left(\frac{w_{i, s f}}{w_{i, i n}}\right)$

(vergelijking 6)

\subsubsection{Groot Zevert Vergisting}

Bij GZV zijn automatisch loggende debietmeters aanwezig op een groot aantal processtromen van het GENIAAL- en RePeat-systeem. Deze zijn gebruikt in de berekening van de scheidingsrendementen en massabalansen in aanvulling op de in paragraaf 2.2.1. beschreven berekeningen. 
Massadebieten (kg/dag) zijn voor alle vloeibare processtromen gelijk aan de debieten (liter/dag), omdat de dichtheden van de vloeibare stromen praktisch gelijk zijn aan $1000 \mathrm{~kg} / \mathrm{m}^{3}$.

Voor de eerste en tweede decanter centrifuge zijn de scheidingsrendementen voor de massadebieten berekend op basis van het drogestofgehalte in de in- en uitgaande stromen (vergelijkingen 1 en 2). Dit omdat de massadebieten van de dikke fracties niet nauwkeurig gemonitord worden. Voor de DAF, microfiltratie (MF) en RO zijn de scheidingsrendementen voor het massadebiet berekend aan de hand van de gemeten debieten. Per bemonsteringsronde zijn hiervoor de gemiddelde debieten over een periode van twee weken gebruikt (één week voorafgaand en één week na de bemonstering). Dit zodat de invloed van toe- en afname van het vloeistofniveau in buffertanks en kelders wegvalt.

De verdere berekeningen zijn gelijk aan de beschrijving in paragraaf 2.2.1. In het GENIAAL-systeem zijn meerdere retourstromen; deze zijn meegenomen in de massabalans; veelal zijn ook de samenstelling en het debiet van deze retourstromen gemeten. Als laatste stap is de berekende massabalans, in lijn met de massabalans voor de andere verwerkers, omgerekend van massadebieten naar een vaste massa van $1000 \mathrm{~kg}$ ingaand digestaat.

Debietmeters op stromen die bestaan uit dikke fractie opgemengd met water gaven geen betrouwbare waarden. Daarom is het scheidingsrendement van de schroefpersen berekend op basis van het drogestofgehalte (vergelijking 1 en 2). Ook is de hoeveelheid ingaande dikke fractie van digestaat niet exact bekend, omdat er geen weegcel aanwezig is. Hetzelfde geldt voor de geproduceerde

bodemverbeteraar. De massa ervan wordt bij afzet naar de afnemer gewogen, dat is een tijdschaal die niet overeenkomt met de monitoring. De massa ingaande dikke fractie en de geproduceerde bodemverbeteraar zijn daarom berekend, wat wel een onnauwkeurigheid introduceert. Als in de toekomst het RePeat-systeem continu zal draaien en daardoor grotere volumes verwerkt, zal het eenvoudiger zijn om de massabalans met een grotere nauwkeurigheid op te stellen. Voor de overige scheidingsapparaten, waaronder de bezinkers en de fosfaatprecipitatietank, zijn wel de gemeten debieten gebruikt. Ook voor het toegevoegde schone water (RO-permeaat) zijn de gemeten debieten gebruikt.

\subsubsection{Ecoson}

De samenstelling van de processtromen en bijbehorende massadebieten zijn aangeleverd door Ecoson waarna in samenwerking de scheidingsrendementen en massabalansen zijn berekend in lijn met de methode beschreven in paragraaf 2.2.2. 


\section{Massabalansen}

\subsection{Groot Zevert Vergisting - GENIAAL}

\subsubsection{Algemene beschrijving}

Groot Zevert Vergisting (hierna GZV) bedrijft een co-vergistingsinstallatie in Beltrum (Gelderland). De verwerkingscapaciteit bedraagt circa 120 kton te vergisten grondstoffen per jaar, al werd deze in 2020 niet volledig benut. In 2020 werd circa 71 kton mest (60 kton varkensdrijfmest, 2 kton runderdrijfmest en 9 kton ongeboren mest) en 22 kton co-producten afkomstig uit de voedselverwerkende industrie verwerkt in de mesofiele co-vergistingsinstallatie tot $81,4 \mathrm{kton}$ digestaat. De biogasproductie daarvan bedroeg 9,7 miljoen $\mathrm{Nm}^{3}$ (12 kton), 55 vol.-\% methaan, en was voor circa $77 \%$ afkomstig uit de co-producten. Als wordt uitgegaan van een biogasproductie van $23 \mathrm{~m}^{3}$ (55 vol.-\% methaan) per ton drijfmest en $100 \mathrm{~m}^{3}$ biogas per ton ongeboren mest, dan was circa $23 \%$ van de biogasproductie afkomstig uit mest (incl. ongeboren mest) en het overige deel uit de co-producten. $\mathrm{Na}$ ontzwaveling werd $6,95 \mathrm{Nm}^{3}$ van het biogas via een circa $5 \mathrm{~km}$ lange pijpleiding geleverd aan een melk verwerkende fabriek van FrieslandCampina in Borculo. De rest werd in biogasmotoren omgezet in 5,6 GWh elektriciteit en circa 5,60 GWh warmte waarvan circa 3,62 GWh effectief benut wordt op het bedrijf voor de biogasontzwaveling, verwarming van de voor- en navergisters en bedrijfsgebouwen en extra verhitting voor hygiënisatie van het digestaat in de laatste navergister. De geproduceerde warmte wordt op jaarbasis niet volledig benut, omdat er in de zomer een overschot is aan warmte. Biogasproductie is waar GZV haar inkomsten uit haalt, daarom streeft GZV naar een zo hoog mogelijk productie hiervan door toevoeging van co-producten. Door de toegevoegde co-producten ontstaat een digestaat met relatief hoge gehalten aan droge stof, stikstof en fosfaat ten opzichte van varkensdrijfmest.

Tot 2018 werd het gehygiëniseerde digestaat zonder verdere scheiding afgezet naar West-Duitsland. Sinds 2019 wordt het digestaat verwerkt middels een door Nijhuis Industries (Doetinchem) ontworpen en geleverd systeem met de merknaam GENIAAL. Het doel is om hiermee de transportkosten voor afzet van digestaat te verlagen door het digestaat te verwerken tot op maat gemaakte bio-gebaseerde meststoffen met herwonnen nutriënten, die beter voldoen aan de vraag in de regio dan alleen dikke en dunne fractie van digestaat, en loosbaar water.

Het GENIAAL-systeem bestaat uit twee in serie geschakelde decanter centrifuges, een microfiltratieinstallatie (MF), een omgekeerde osmose-installatie (reverse osmosis-installatie, RO) en een ionenwisselaar (IO). De keuze voor deze opstelling is gebaseerd op het doel om scheiding te realiseren met een laag chemicaliënverbruik. De producten zijn dikke fractie van digestaat, NK-concentraat, een organische meststof en loosbaar water. Alle producten, m.u.v. de fosfaatrijke dikke fractie, worden binnen Nederland afgezet waardoor langeafstandstransport wordt beperkt. De dikke fractie, circa $15 \%$ van de massa van het ingaande digestaat, wordt deels afgezet in Duitsland en deels verder verwerkt met het systeem genaamd RePeat (paragraaf 3.2). De organische meststof is een stikstofrijke meststof die bestaat uit concentraat van de MF waar - afhankelijk van het gewenste fosfaatgehalte van de afnemer - slib van de tweede decanter centrifuge bij wordt gemengd. Deze organische meststof wordt grotendeels binnen Nederland afgezet naar akkerbouwers. Het NK-concentraat wordt geblend met een extern verkregen oplossing van ureum en ammoniumnitraat (Urean) en een via terugwinning verkregen ammoniumsulfaatoplossing tot een bemestingsproduct op maat. Dit product wordt onder de merknaam Groene Weide Meststof (GWM) als kunstmestvervanger afgezet naar agrariërs in de Achterhoek. In het project Kunstmestvrije Achterhoek zijn veldproeven en demonstratieproeven uitgevoerd waarbij de effectiviteit van de GWM ten opzichte van reguliere stikstofkunstmest (blend van NKS) is bepaald (Ehlert, 2020). Het geproduceerde loosbare water wordt geloosd op oppervlaktewater. 


\subsubsection{Technische procesbeschrijving}

De gemiddelde totale verblijftijd in de vergisters (inclusief navergisters) is circa 50 dagen. Het digestaat wordt in de navergister gehygiëniseert bij $52{ }^{\circ} \mathrm{C}$ met behulp van restwarmte van de biogasmotoren. Het digestaat wordt door een combinatie van scheidingstechnieken verwerkt tot verschillende meststoffen en loosbaar water (Figuur 3.1). De eerste stap is scheiding van het digestaat in een dikke en dunne fractie door een decanter centrifuge waarbij $\mathrm{MgCl}_{2}$-oplossing wordt gedoseerd om fosfaat te binden. Dit resulteert in een fosfaatrijke dikke fractie die het hele jaar door wordt afgezet naar afnemers in Duitsland. De dunne fractie, het centraat van de eerste decanter centrifuge, wordt behandeld in een tweede decanter centrifuge met dosering van polymeervloeistof om fijne organische stof af te vangen. Het centraat daarvan wordt hierna door de MF ontdaan van het restant aan fijne deeltjes en fosfaat. Het permeaat van de MF wordt in de RO een factor 2 tot 3 opgeconcentreerd tot het NK-concentraat. Het permeaat van de RO wordt, na zuivering door de ionenwisselaars, voor het grootste deel geloosd en deels hergebruikt op locatie. De dikke fractie van de tweede decanter centrifuge wordt grotendeels gemengd met een deel van het concentraat van de MF en gezamenlijk afgezet. Het overige deel van het concentraat van de MF wordt teruggevoerd naar de laatste navergister.

Het originele ontwerp bestond uit een combinatie van een decanter centrifuge gevolgd door een DAF (Dissolved Air Flotation-installatie). De DAF functioneerde niet naar verwachting. Het systeem is daarom aangepast, waarbij de functie van de DAF-installatie is overgenomen door een tweede decanter centrifuge. De DAF is nog steeds onderdeel van het systeem maar wordt niet meer belucht, waardoor de scheidingsrendementen ervan verwaarloosbaar zijn. De in de DAF afgeschraapte drijflaag wordt teruggevoerd naar het influent van de tweede decanter centrifuge. 


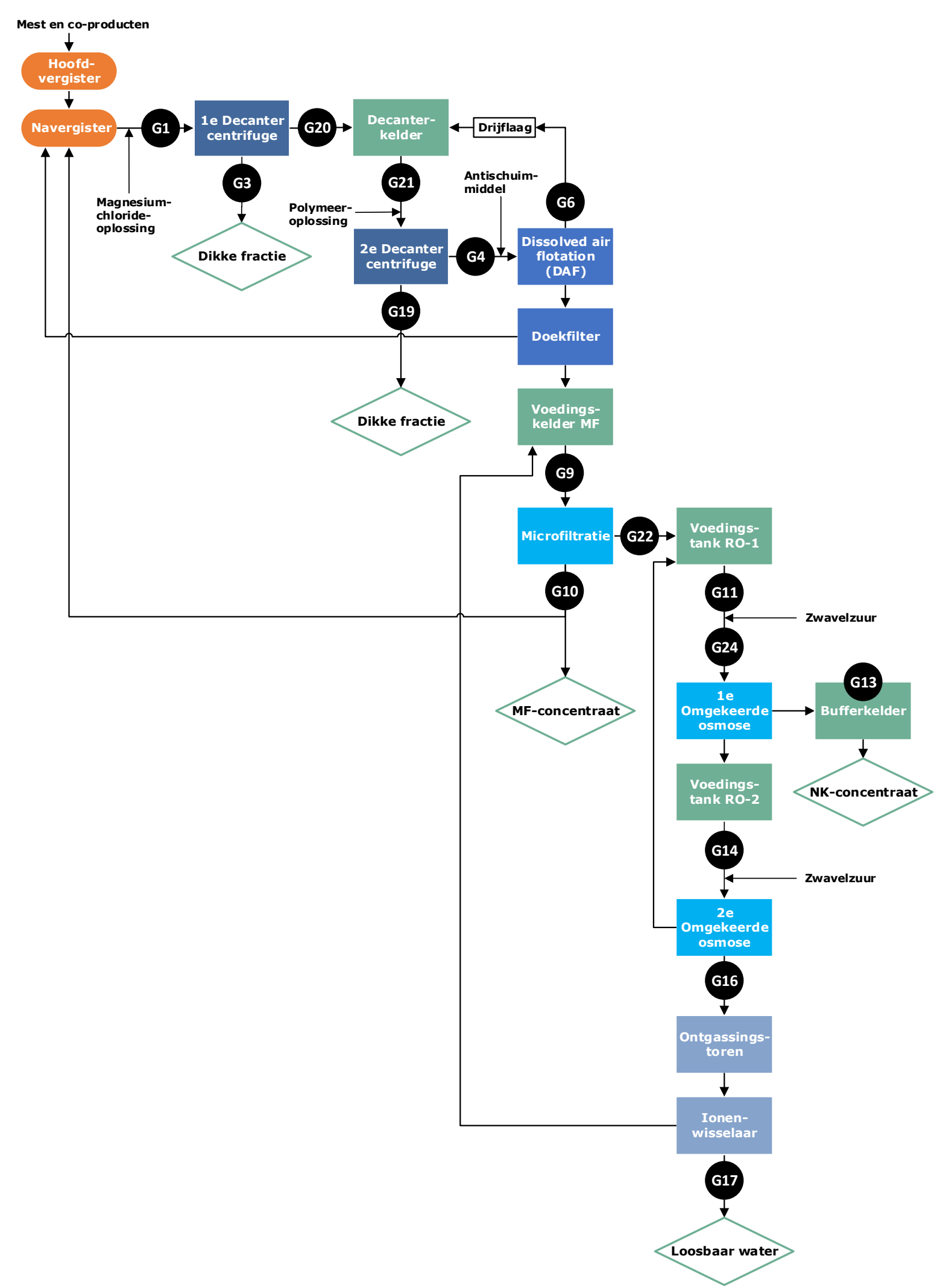

Figuur 3.1 Processtroomdiagram van het digestaatverwerkende systeem 'GENIAAL' van Groot Zevert Vergisting; bemonsteringspunten zijn aangegeven met een letter-nummercombinatie.

\subsubsection{Scheidingsrendementen}

\subsubsection{Eerste decanter centrifuge}

Voor de eerste decanter centrifuge wordt een $\mathrm{MgCl}_{2}$-oplossing gedoseerd om het nog opgeloste fosfaat neer te slaan als struviet $\left(\mathrm{Mg}\left(\mathrm{NH}_{4}\right) \mathrm{PO}_{4} \cdot 6\left(\mathrm{H}_{2} \mathrm{O}\right)\right)$ en af te scheiden naar de dikke fractie van de eerste en tweede decanter centrifuges. De eerste decanter centrifuge produceert een rulle en vezelrijke dikke 
fractie. $\mathrm{Er}$ is bewust gekozen voor toevoeging van $\mathrm{MgCl}_{2}$ in plaats van een ijzersulfaat om hoge gehalten aan ijzer en zwavel in de eindproducten te voorkomen. Er wordt gestuurd op een lage dosering van circa 1,75 liter $32 \% \mathrm{MgCl}_{2}$-oplossing per ton influent van de eerste decanter centrifuge. Chloride werd niet meegenomen in de monitoring, maar berekend is dat deze dosering het chloridegehalte in het $\mathrm{NK}$-concentraat met circa $0,9 \mathrm{~g} \mathrm{Cl} / \mathrm{kg}$ verhoogt t.o.v. het chloridegehalte in het digestaat. Bewust is gekozen geen polymeren toe te voegen voor de eerste decanter centrifuge, zodat de dikke fractie ervan vrij is van polymeren waardoor er, na afscheiding van het fosfaat dat het nog bevat, perspectieven zijn voor de opwerking tot veenvanger (paragraaf 3.2). Dat zou onder de nieuwe EU-meststoffenverordening een voordeel kunnen zijn bij de afzet van de dikke fractie in het buitenland (hoofdstuk 5).

Tabel 3.1 toont de samenstelling van de in- en uitgaande stromen van de eerste decanter centrifuge en de berekende scheidingsrendementen. De massabalans is opgesteld per ton digestaat uit de hoofdvergister. Aan de navergister wordt $216 \mathrm{~kg}$ aan retourstromen uit het GENIAAL-systeem bijgemengd waardoor, per ton digestaat uit de hoofdvergister (na toevoeging van $2,3 \mathrm{~kg} \mathrm{MgCl}_{2}-$ oplossing), $1218 \mathrm{~kg}$ digestaat door de eerste decanter centrifuge wordt verwerkt. Circa $50 \%$ van de organische stof en $63 \%$ van het fosfaat komen terecht in de dikke fractie. Van de goed oplosbare kationen kalium en ammonium komt respectievelijk $13 \%$ en $16 \%$ terecht in de dikke fractie. De som van in- en uitgaande stromen wijkt voor alle componenten maximaal $8 \%$ af van $100 \%$ en dit komt door meetfouten in de flowmeters en bij analyse van de parameters.

Tabel 3.1 Samenstelling van de in- en uitgaande stromen van de eerste decanter centrifuge van Groot Zevert Vergisting en het berekende scheidingsrendement als percentage van de ingaande stroom, voor de som tussen haakjes de standaardafwijking. Gemiddelde van vijf bemonsteringen. ${ }^{1}$

\begin{tabular}{|c|c|c|c|c|c|c|c|c|}
\hline \multirow[b]{2}{*}{ Parameter } & \multicolumn{4}{|c|}{ Samenstelling } & \multicolumn{4}{|c|}{ Scheidingsrendement } \\
\hline & Eenheid & Influent ${ }^{2}$ & Dunne fractie ${ }^{3}$ & Dikke fractie 4 & Eenheid ${ }^{5}$ & Dunne fractie & Dikke fractie & SOM \\
\hline Massa & $(\mathrm{kg})$ & 1218 & 1070 & 148 & $\%$ & 88 & 12 & $100( \pm 1,4)$ \\
\hline os & $(\mathrm{g} / \mathrm{kg})$ & 59 & 33 & 242 & $\%$ & 48 & 50 & $98( \pm 2,7)$ \\
\hline $\mathrm{P}_{2} \mathrm{O}_{5}$ & $(\mathrm{~g} / \mathrm{kg})$ & 3,9 & 1,4 & 20 & $\%$ & 32 & 63 & $95( \pm 5,1)$ \\
\hline $\mathrm{N}-\mathrm{NH}_{4}$ & $(\mathrm{~g} / \mathrm{kg})$ & 5,0 & 4,7 & 6,6 & $\%$ & 83 & 16 & $99( \pm 3,4)$ \\
\hline $\mathrm{S}$ & $(\mathrm{g} / \mathrm{kg})$ & 0,67 & 0,51 & 1,9 & $\%$ & 66 & 34 & $100( \pm 4,9)$ \\
\hline $\mathrm{K}$ & $(\mathrm{g} / \mathrm{kg})$ & 4,5 & 4,7 & 4,6 & $\%$ & 91 & 13 & $103( \pm 4,7)$ \\
\hline $\mathrm{Ca}$ & $(\mathrm{g} / \mathrm{kg})$ & 1,8 & 0,94 & 7,7 & $\%$ & 48 & 53 & $101( \pm 6,0)$ \\
\hline \multicolumn{9}{|c|}{$\begin{array}{l}1 \text { Massa: totale massa van processtroom per ton verwerkt digestaat uit de hoofdvergister, DS: droge stof, OS: organische stof, n.g.: niet } \\
\text { geanalyseerd. }\end{array}$} \\
\hline \multicolumn{9}{|c|}{$\begin{array}{l}2 \text { Digestaat uit de navergister na toevoeging van circa } 1,75 \text { I (2,3 kg) } 32 \% \mathrm{MgCl}_{2} \text {-oplossing per ton influent van de eerste decanter centrifuge } \\
\text { (bemonsteringspunt } \mathrm{G} 1 \text { ). }\end{array}$} \\
\hline \multicolumn{9}{|c|}{3 Dunne fractie van de eerste decanter centrifuge voor toevoeging slib van de DAF (bemonsteringspunt G20). } \\
\hline \multicolumn{9}{|c|}{4 Dikke fractie van de eerste decanter centrifuge (bemonsteringspunt G3). } \\
\hline \multicolumn{9}{|c|}{5 Percentage t.o.v. de ingaande massa (inclusief toegevoegde chemie en bijbehorend oploswater). } \\
\hline
\end{tabular}

\subsubsection{Tweede decanter centrifuge}

De tweede decanter centrifuge heeft als doel het verwijderen van nog overgebleven fijne deeltjes om de MF verderop in de lijn te ontlasten; hiervoor wordt een polymeervloeistof toegevoegd. Tijdens een van de bemonsteringsrondes werd er ook, als test, $\mathrm{Fe}_{2}\left(\mathrm{SO}_{4}\right)_{3}$-oplossing toegevoegd voor de tweede decanter centrifuge. Dit had als doel nog meer fosfaat te verwijderen om het fosfaatgehalte in het NKconcentraat te verlagen en de MF verder te ontlasten. Op basis van ervaringen vanuit GZV gaf dit inderdaad de gewenste effecten. Toch is afgezien van de voortzetting ervan, omdat het leidde tot ijzervervuiling op de membranen van de MF en een verdere verhoging van het zwavelgehalte van het NK-concentraat en het tevens kostentechnisch niet uit kon. 
Tabel 3.2 toont de samenstelling van de in- en uitgaande stromen van de tweede decanter centrifuge en de berekende scheidingsrendementen. Per ton digestaat uit de hoofdvergister ontstaat $1152 \mathrm{~kg}$ influent voor de tweede decanter centrifuge door bijmenging van slib van de DAF en spoelwater van beide decanter centrifuges aan de dunne fractie van de eerste decanter centrifuge. Daarna wordt per $\mathrm{m}^{3}$ influent van de tweede decanter centrifuge gemiddeld $85 \mathrm{~kg}$ polymeeroplossing toegevoegd. Daardoor bedraagt de massa van de dikke en dunne fractie van de tweede decanter centrifuge gezamenlijk $1266 \mathrm{~kg}$ per ton digestaat uit de hoofdvergister. Het percentage van de totale massa dat naar de dikke fractie gaat $(7,6 \%)$ is kleiner dan bij de eerste decanter centrifuge $(12 \%)$. Van het ingaande fosfaat eindigt $63 \%$ in de dikke fractie en $34 \%$ in de dunne fractie. De som van in- en uitgaande stromen wijkt voor alle componenten maximaal $4 \%$ af van $100 \%$ door meetonzekerheden. De eerste en tweede decanter centrifuge scheiden gezamenlijk circa $80 \%$ van de ingaande organische stof en het ingaande fosfaat af.

Tabel 3.2 Samenstelling van de in- en uitgaande stromen van de tweede decanter centrifuge van Groot Zevert Vergisting en de berekende scheidingsrendementen als percentage van de ingaande stroom, voor de som tussen haakjes de standaardafwijking. Gemiddelde van vijf bemonsteringen. ${ }^{1}$

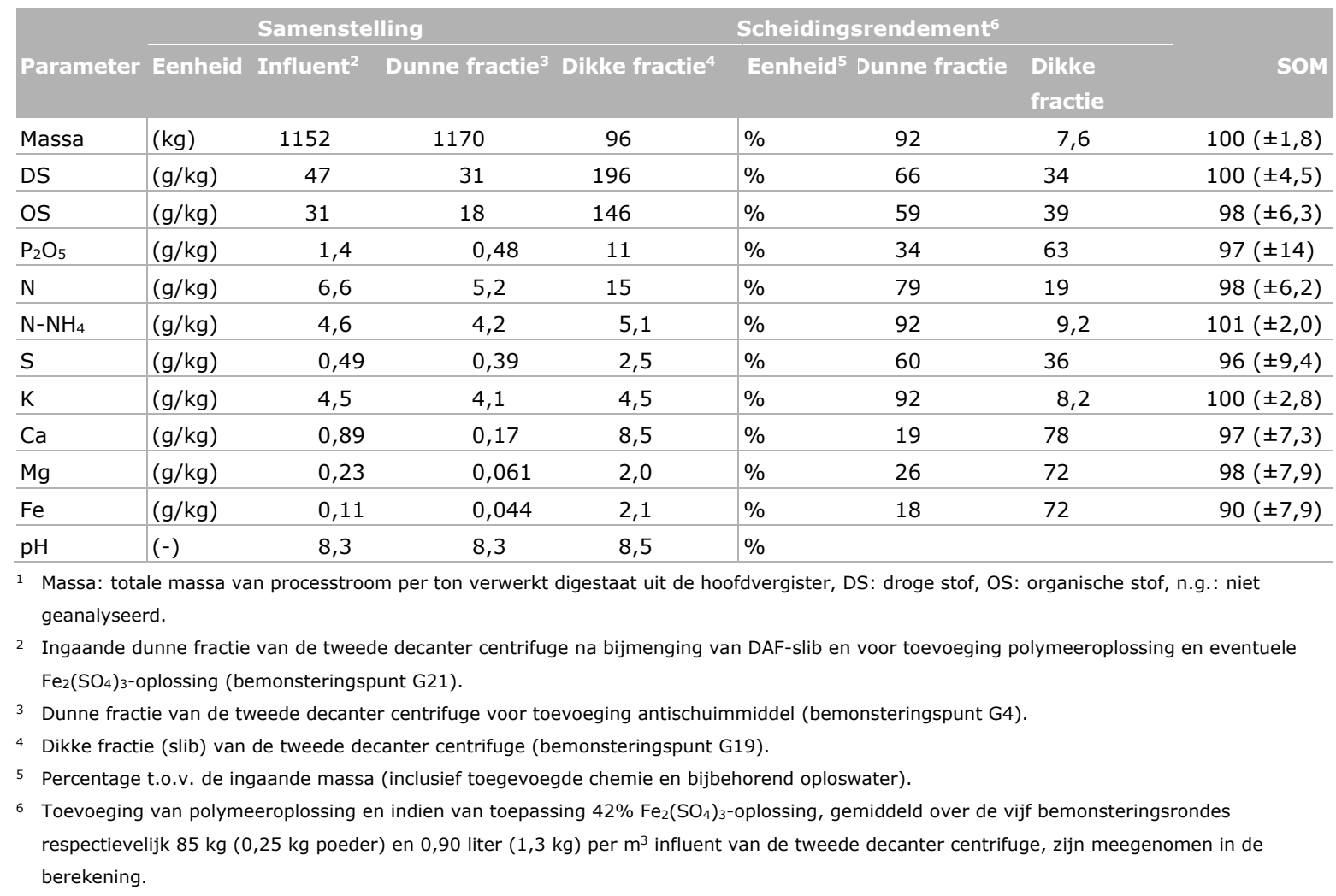

\subsubsection{Dissolved Air Flotation-installatie}

Vlak voor de DAF wordt $10 \mathrm{ml}$ antischuimmiddel per ton influent van de DAF toegevoegd. De DAF werd niet belucht en doet dus geen dienst meer als DAF. De installatie is nog wel onderdeel van het systeem en de schrapers zijn nog in werking. De samenstelling van de afgeschraapte drijflaag week niet af van de ingaande stroom van de DAF. De scheidingsrendementen over de DAF zijn daarom voor de totale massa en alle gemeten componenten praktisch gelijk aan elkaar. De afgeschraapte totale massa aan drijflaag is circa $6 \%$ van de totale massa van de ingaande stroom van de DAF en is opgenomen in de massabalans. De drijflaag wordt teruggevoerd naar de kelder tussen de eerste en tweede decanter centrifuge.

\subsubsection{Microfiltratie-installatie}

Het doel van de MF is om fosfaat en fijne organische stof dat niet door de voorliggende stappen is verwijderd, af te vangen om vervuiling van de RO membranen te voorkomen. De MF werkt als batchproces en bestaat uit drie identieke installaties die elkaar opvolgen wat betreft de processtappen van op-concentreren en afpompen. Het influent wordt over een membraan geperst dat fijne particuliere 
deeltjes tegenhoudt. Opgeloste zouten en organische zuren (met name fulvozuren) kunnen het membraan wel passeren. Het concentraat van de MF, een slib, werd ten tijde van de bemonsteringen deels teruggevoerd naar de navergister met als doel verdere afbraak en het alsnog afvangen van de fijne deeltjes die het bevat door beide decanter centrifuges. De ervaring van GZV is dat dit afvangen niet gebeurde en dat door het terugvoeren juist fijne deeltjes in het systeem accumuleerden, waardoor de tweede decanter centrifuge en de MF slechter gingen presteren. Ten tijde van de bemonsteringen werd het andere deel van het concentraat van de MF, gemengd met de dikke fractie van de tweede decanter centrifuge, afgevoerd naar akkerbouwers. Het permeaat van de MF is de voeding van de RO. Tabel 3.3 toont de samenstelling van de in- en uitgaande stromen van de MF en de berekende scheidingsrendementen. Van de totale massa van de ingaande stroom komt $45 \%$ terecht in het concentraat. Organische stof en fosfaat worden nagenoeg volledig (beide $86 \%$ ) afgevangen, waardoor een permeaat met een laag fosfaatgehalte ontstaat $(0,2 \mathrm{~g} / \mathrm{kg})$ en een N-NH$/ \mathrm{N}$ ratio van $>90 \%$. Vanwege de omvang van de concentraatstroom ( $45 \%$ van het ingaande debiet) wordt tevens ook $45 \%$ van de ingaande massa aan ammonium en kalium afgevangen in het concentraat van de MF.

Tabel 3.3 Samenstelling van de in- en uitgaande stromen van de microfiltratie van Groot Zevert Vergisting en het berekende scheidingsrendement als percentage van het influent; voor de som tussen haakjes de standaardafwijking. Gemiddelde van vijf bemonsteringen. ${ }^{1}$

\begin{tabular}{|c|c|c|c|c|c|c|c|c|}
\hline \multirow[b]{2}{*}{ Parameter } & \multicolumn{4}{|c|}{ Samenstelling } & \multicolumn{3}{|c|}{ Scheidingsrendement } & \multirow[b]{2}{*}{ SOM } \\
\hline & Eenheid & Influent ${ }^{2}$ & Concentraat ${ }^{3}$ & Permeaat ${ }^{4}$ & Eenheid $^{5}$ & Permeaat & Concentraat & \\
\hline Massa & $(\mathrm{kg})$ & 1221 & 548 & 673 & $\%$ & 55 & 45 & $100( \pm 9,3)$ \\
\hline OS & $(\mathrm{g} / \mathrm{kg})$ & 18 & 35 & 6,7 & $\%$ & 20 & 86 & $106( \pm 8,9)$ \\
\hline $\mathrm{P}_{2} \mathrm{O}_{5}$ & $(\mathrm{~g} / \mathrm{kg})$ & 0,50 & 0,96 & 0,18 & $\%$ & 18 & 86 & $103( \pm 13)$ \\
\hline $\mathrm{N}-\mathrm{NH}_{4}$ & $(\mathrm{~g} / \mathrm{kg})$ & 4,1 & 4,2 & 4,0 & $\%$ & 53 & 46 & $99( \pm 9,0)$ \\
\hline $\mathrm{S}$ & $(\mathrm{g} / \mathrm{kg})$ & 0,46 & 0,63 & 0,35 & $\%$ & 41 & 64 & $105( \pm 18)$ \\
\hline $\mathrm{K}$ & $(\mathrm{g} / \mathrm{kg})$ & 4,1 & 4,1 & 4,0 & $\%$ & 55 & 45 & $100( \pm 8,9)$ \\
\hline $\mathrm{Ca}$ & $(\mathrm{g} / \mathrm{kg})$ & 0,18 & 0,38 & 0,03 & $\%$ & 9 & 92 & $101( \pm 9,4)$ \\
\hline \multicolumn{9}{|c|}{$\begin{array}{l}1 \text { Massa: totale massa van processtroom per ton verwerkt digestaat uit de hoofdvergister, DS: droge stof, OS: organische stof, n.g.: niet } \\
\text { geanalyseerd. }\end{array}$} \\
\hline \multicolumn{9}{|c|}{2 Influent microfiltratie na voedingskelder (bemonsteringspunt G9). } \\
\hline \multicolumn{9}{|c|}{3 Concentraat van de microfiltratie-installatie (bemonsteringspunt G10). } \\
\hline \multicolumn{9}{|c|}{$\begin{array}{l}4 \text { Permeaat van de microfiltratie-installatie voor het bijmengen van het concentraat van de tweede omgekeerde osmose-installatie } \\
\text { (bemonsteringspunt G22). }{ }^{5} \text { Percentage t.o.v. de ingaande massa. }\end{array}$} \\
\hline
\end{tabular}

\subsubsection{Omgekeerde osmose-installatie}

Het GENIAAL-systeem werkt met twee in serie geschakelde, RO-installaties die beide bestaan uit drie 'stages', waarbij de tweede RO het permeaat van de eerste RO verder behandelt. Voor RO's in de mestverwerking wordt in de regel zwavelzuur toegevoegd om de $\mathrm{pH}$ te verlagen om de retentie van ammoniak in de vorm van $\mathrm{NH}_{4}$ te verhogen en scaling van zouten als calciumcarbonaat $\left(\mathrm{CaCO}_{3}\right)$ te voorkomen. De RO van GZV wordt bedreven op niet-conventionele procescondities met als doel een lagere benodigde zwavelzuurdosering, om zo een hoog zwavelgehalte in het NK-concentraat te voorkomen. De eerste RO wordt bedreven bij een relatief hoge influent $\mathrm{pH}$ van circa 8,3 (lage zwavelzuurdosering), waardoor circa $10 \%$ van de $\mathrm{N}-\mathrm{NH}_{3}$ aanwezig is als $\mathrm{NH}_{3}$ en niet als $\mathrm{NH}_{4}{ }^{+}$. Omdat $\mathrm{NH}_{3}$ ongeladen is, passeert dit het membraan waardoor de eerste RO een permeaat met een hoge concentratie $\mathrm{N}-\mathrm{NH}_{3}$ en een hoge $\mathrm{pH}$ produceert. Het permeaat van de eerste $\mathrm{RO}$ wordt verder aangezuurd en daarna behandeld op de tweede RO waar nagenoeg alle overgebleven $\mathrm{N}-\mathrm{NH}_{3}$ in de vorm van $\mathrm{NH}_{4}{ }^{+}$wordt afgevangen. Verlaging van de $\mathrm{pH}$ van het influent van de tweede $\mathrm{RO}$ kost minder zuur dan verlaging van de $\mathrm{pH}$ van het influent van de eerste $\mathrm{RO}$ vanwege de kleinere $\mathrm{pH}$ buffercapaciteit. Het concentraat van de tweede RO wordt teruggevoerd naar de voedingstank van de 
eerste RO. Voor de eerste RO wordt, om zoutaanslag te voorkomen, ook 3 liter antiscalant per ton influent van beide RO's toegevoegd.

Tabel 3.4 toont de samenstelling van de in- en uitgaande stromen van de twee RO's en de berekende concentratiefactor. Omdat alle componenten in het influent van de eerste RO voor praktisch $100 \%$ in het NK-concentraat terechtkomen, is de concentratiefactor getoond in plaats van de scheidingsrendementen. De berekende concentratiefactor bedraagt 2 op basis van de concentraties kalium en $\mathrm{N}-\mathrm{NH}_{4}$.

De enige gemeten componenten in het permeaat van de tweede RO die nog boven de kwantificeringslimiet voor de toegepaste chemische analyse liggen, zijn stikstof, $\mathrm{N}-\mathrm{NH}_{4}$, zwavel en kalium. Het permeaat van de tweede RO bevat nog 1,3 g/kg zwavel. Mogelijk bestaat dit uit waterstofsulfide $\left(\mathrm{H}_{2} \mathrm{~S}\right)$ en/of kleine organische zwavelverbindingen, zoals mercaptanen, die ongeladen zijn en dus door het membraan van de tweede RO heen kunnen. Sulfaat $\left(\mathrm{SO}_{4}{ }^{2-}\right)$ kan vanwege zijn lading slecht door de RO-membranen heen, het gemeten sulfaatgehalte in het permeaat van de tweede RO is voor de individuele monsters maximaal $6 \%$ van het totaal-S gehalte en meestal minder dan $1 \%$. Het vermoeden is dat de hoge zwavelconcentratie in het permeaat van de tweede RO te wijten is aan waterstofsulfide en niet aan kleine organische zwavelverbindingen, omdat die laatsten makkelijk verteerbaar zijn en dus al in de vergister zouden moeten zijn omgezet in methaan. Dit zwavel wordt nagenoeg volledig verwijderd in de ontgassingstoren en ionenwisselaar (zie Tabel 3.5) en er is daarmee geen sprake van verhoogde zwavelgehalten in het geloosde effluent. Het hoge zwavelgehalte in het permeaat van de $\mathrm{RO}$ is wel een aandachtspunt voor de veiligheid van de medewerkers. De zwavelanalyses zijn uitgevoerd door het CBLB waar deze watermonsters zónder aanzuring direct gemeten worden op een ICP-OES. Een recente verkenningsproef heeft aangetoond dat wanneer dezelfde permeaatmonsters door LUFA-NW gemeten worden - met een destructiemethode voor mestmonsters - het zwavelgehalte $<0.1 \mathrm{~g} / \mathrm{kg}$ ligt.

Vermoed wordt dat de standaard destructie van de monsters met koningswater (aqua regia) resulteert in vervluchtiging van waterstofsulfide voorafgaand aan de chemische analyse wat leidt tot een onderschatting van het totale zwavelgehalte in de monsters. Vervolgonderzoek moet bevestigen dat dit inderdaad komt door toevoeging van koningswater en dat het inderdaad gaat om waterstofsulfide. Mogelijk speelt dit, vanwege de vorming van waterstofsulfide in vergisters, ook bij andere digestaatverwerkingsinstallaties waar geen ijzer wordt gedoseerd in de vergister. Aanbevolen wordt om hier verder onderzoek naar de doen.

Voor de beide RO's wordt, om de retentie van stikstof in de vorm van ammonium $\left(\mathrm{NH}_{4}^{+}\right)$te verhogen en om vervuiling door zoutafzettingen tegen te gaan, zwavelzuur toegevoegd. De dosering hiervan is $\mathrm{pH}$-gestuurd en wordt niet gemeten door debietmeters of als pompdebieten. Op basis van de hoeveelheid zwavel in het influent van de eerste RO, het NK-concentraat en het permeaat van de tweede RO is de dosering berekend op circa 1,9 liter $(3,4 \mathrm{~kg}) 96 \%$ zwavelzuur per ton influent van de gecombineerde RO's. Dit komt neer op circa 1,3 liter $(2,3 \mathrm{~kg}) 96 \%$ zwavelzuur, oftewel 0,73 kg zwavel per ton verwerkt digestaat uit de hoofdvergister. De totale massa's aan concentraat van de eerste RO $(313 \mathrm{~kg}$ ) en het permeaat van de tweede RO $(374 \mathrm{~kg})$ zijn gezamenlijk groter dan de totale massa van het influent $(673 \mathrm{~kg})$. Dit verschil is groter dan de toegevoegde massa zwavelzuur en wordt toegeschreven aan de foutmarge van de debietmeters. 
Tabel 3.4 Samenstelling van de in-en uitgaande stromen van de twee in serie geschakelde omgekeerde osmose-installaties van Groot Zevert Vergisting en de berekende concentratiefactor daarvan, gemiddelde van vijf bemonsteringen. ${ }^{1}$

\begin{tabular}{|c|c|c|c|c|c|c|}
\hline \multirow{2}{*}{\multicolumn{2}{|c|}{ Parameter }} & \multicolumn{4}{|c|}{ Samenstelling } & \multirow[t]{2}{*}{ Concentratiefactor ${ }^{5}$} \\
\hline & & Eenheid & Influent ${ }^{2}$ & Concentraat eerste $\mathrm{RO}^{3}$ & Permeaat tweede $\mathrm{RO}^{4}$ & \\
\hline \multicolumn{2}{|c|}{ Massa } & $(\mathrm{kg})$ & 673 & 313 & 374 & - \\
\hline \multicolumn{2}{|c|}{ DS } & $(\mathrm{g} / \mathrm{kg})$ & 17 & 37 & n.g. & - \\
\hline \multicolumn{2}{|c|}{ OS } & $(\mathrm{g} / \mathrm{kg})$ & 6,7 & 14 & n.g. & - \\
\hline \multicolumn{2}{|c|}{$\mathrm{P}_{2} \mathrm{O}_{5}$} & $(\mathrm{~g} / \mathrm{kg})$ & 0,18 & 0,34 & $<0,00023$ & - \\
\hline \multicolumn{2}{|c|}{$\mathrm{N}$} & $(\mathrm{g} / \mathrm{kg})$ & 4,2 & 8,1 & 0,11 & 1,9 \\
\hline \multicolumn{2}{|c|}{$\mathrm{N}-\mathrm{NH}_{4}$} & $(\mathrm{~g} / \mathrm{kg})$ & 4,0 & 8,0 & 0,10 & 2,0 \\
\hline \multicolumn{2}{|c|}{$\mathrm{S}$} & $(\mathrm{g} / \mathrm{kg})$ & 0,35 & 1,5 & 1,3 & - \\
\hline \multicolumn{2}{|c|}{$\mathrm{K}$} & $(\mathrm{g} / \mathrm{kg})$ & 4,0 & 7,9 & 0,015 & 2,0 \\
\hline \multicolumn{2}{|c|}{$\mathrm{Ca}$} & $(\mathrm{g} / \mathrm{kg})$ & 0,027 & 0,059 & $<0,0012$ & - \\
\hline \multicolumn{2}{|c|}{$\mathrm{Mg}$} & $(\mathrm{g} / \mathrm{kg})$ & 0,016 & 0,040 & $<0,00015$ & - \\
\hline \multicolumn{2}{|c|}{$\mathrm{Fe}$} & $(\mathrm{g} / \mathrm{kg})$ & $<0,010$ & $<0,010$ & $<0,00009$ & - \\
\hline \multicolumn{2}{|c|}{$\mathrm{pH}$} & $(-)$ & 8,5 & 8,4 & 6,9 & - \\
\hline \multicolumn{7}{|c|}{$\begin{array}{l}1 \text { Massa: totale massa van processtroom per ton verwerkt digestaat uit de hoofdvergister, DS: droge stof, OS: organische stof, n.g.: niet } \\
\text { geanalyseerd. }\end{array}$} \\
\hline en van het concentraat van de tweede RO en voor toevoeging zwavelzuur (bemonsteringspunt & \multicolumn{6}{|c|}{ 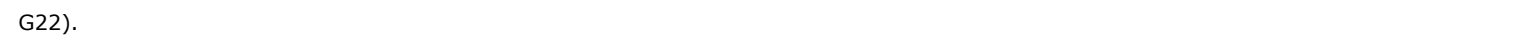 } \\
\hline \multicolumn{7}{|c|}{3 NK-concentraat van de eerste RO (bemonsteringspunt G13). } \\
\hline \multicolumn{7}{|c|}{4 Permeaat van de tweede RO voor de ontgassingstoren (bemonsteringspunt G16). } \\
\hline \multicolumn{7}{|c|}{$\begin{array}{l}5 \text { Concentratie in het } \mathrm{NK} \text {-concentraat gedeeld door de concentratie in het influent van de eerste omgekeerde osmose-installatie, alleen berekend } \\
\text { voor } \mathrm{N}, \mathrm{N}-\mathrm{NH}_{4} \text { en } \mathrm{K} \text {. }\end{array}$} \\
\hline
\end{tabular}

\subsubsection{Ionenwisselaars}

Het permeaat van de tweede RO gaat eerst nog door de ontgassingstoren waar lucht door het permeaat wordt geblazen om $\mathrm{CO}_{2}$ te strippen en zuurstof in te brengen en gaat vervolgens achtereenvolgend over een kationenwisselaar en anionenwisselaar. De afgezogen lucht van de ontgassingstoren wordt over zowel een zure als basische luchtwasser en een biobedfilter geleid. Het regeneratiewater van de ionenwisselaars wordt teruggevoerd naar de voedingskelder voor de MF. De ionenwisselaars werden ten tijde van de bemonsteringen ongeveer eens geregenereerd per $100 \mathrm{~m}^{3}$ influent van de ionenwisselaars. Tabel 3.5 toont de samenstelling van het influent (voor de ontgassingstoren) en het effluent van de ionenwisselaars en het verwijderingspercentage van de ionenwisselaars. Het zwavelgehalte in het effluent van de ionenwisselaars $(0,0029 \mathrm{~g} / \mathrm{kg})$ is ten opzichte van het permeaat van de tweede RO $(1,3 \mathrm{~g} / \mathrm{kg})$ sterk gedaald. De ontgassingstoren stript vluchtige zwavelverbindingen mee en zorgt verreweg voor de grootste daling hierin. Het effluent van de ontgassingstoren is niet bemonsterd, het effluent van de kationenwisselaar echter wel. De gemiddelde zwavelconcentratie daarvan over de vijf bemonsteringsronden is $0,0091 \mathrm{~g} \mathrm{~S} / \mathrm{kg}$. Waterstofsulfide en organische zwavelverbindingen hebben geen positieve lading en kunnen daarom niet door een kationenwisselaar worden afgevangen; de sterke concentratiedaling is dus toe te schrijven aan de ontgassingstoren. De anionenwisselaar verlaagt de zwavelconcentratie verder van $0,0091 \mathrm{~g} \mathrm{~S} / \mathrm{kg}$ naar 0,0029 g S/kg. De vorm waarin zwavel voorkomt in het permeaat zal verder onderzocht worden in samenwerking met GZV. Op massabasis is zwavel verreweg de meest verwijderde component. Zowel stikstof, $\mathrm{N}-\mathrm{NH}_{4}$, zwavel als kalium wordt voor minimaal $97 \%$ verwijderd. 
Tabel 3.5 Samenstelling van de in- en uitgaande stromen van de ionenwisselaars van Groot Zevert Vergisting en het berekende verwijderingspercentage, gemiddelde van vijf bemonsteringen. ${ }^{1}$

\begin{tabular}{|c|c|c|c|c|}
\hline \multirow[b]{2}{*}{ Parameter } & \multicolumn{3}{|c|}{ Samenstelling } & \multirow[t]{2}{*}{ Verwijderingspercentage ${ }^{4}$} \\
\hline & Eenheid & Permeaat tweede $\mathbf{R O}^{2}$ & Loosbaar water ${ }^{3}$ & \\
\hline Massa & $(\mathrm{kg})$ & 374 & 374 & - \\
\hline OS & $(\mathrm{g} / \mathrm{kg})$ & - & - & - \\
\hline $\mathrm{P}_{2} \mathrm{O}_{5}$ & $(\mathrm{~g} / \mathrm{kg})$ & $<0,00023$ & $<0,00023$ & - \\
\hline $\mathrm{N}-\mathrm{NH}_{4}$ & $(\mathrm{~g} / \mathrm{kg})$ & 0,10 & 0,00020 & 99,8 \\
\hline $\mathrm{S}$ & $(\mathrm{g} / \mathrm{kg})$ & 1,3 & 0,0029 & 99,8 \\
\hline $\mathrm{K}$ & $(\mathrm{g} / \mathrm{kg})$ & 0,015 & $<0,00040$ & $>97,4$ \\
\hline $\mathrm{Ca}$ & $(\mathrm{g} / \mathrm{kg})$ & $<0,0012$ & $<0,0012$ & - \\
\hline \multicolumn{5}{|c|}{$\begin{array}{l}\text { Massa: totale massa van processtroom per ton verwerkt digestaat uit de hoofdvergister, DS: droge stof, OS: organische stof, n.g.: niet } \\
\text { geanalyseerd. }\end{array}$} \\
\hline \multicolumn{5}{|c|}{2 Permeaat van de tweede omgekeerde osmose-installatie voor de ontgassingstoren (bemonsteringspunt G16). } \\
\hline \multicolumn{5}{|c|}{3 Na kationen- en anionenwisselaar, regeneratietank en schoonwaterkelder (bemonsteringspunt G17). } \\
\hline \multicolumn{5}{|c|}{$\begin{array}{l}\text { Het werkelijke verwijderingspercentage kan niet berekend worden vanwege concentraties onder de kwantificeringslimiet (LOQ), maar is } \\
\text { minimaal } 97,4 \% \text {. }\end{array}$} \\
\hline
\end{tabular}

\subsubsection{Massabalans}

Een massabalans is opgesteld op basis van de gemeten samenstellingen van de genomen monsters, de daaruit berekende scheidingsrendementen en de gegevens over het chemieverbruik. Figuur 3.2 en Figuur 3.3 tonen de stroomdiagrammen voor de totale massa van het verwerkte digestaat en de elementen stikstof, fosfaat en kalium. 


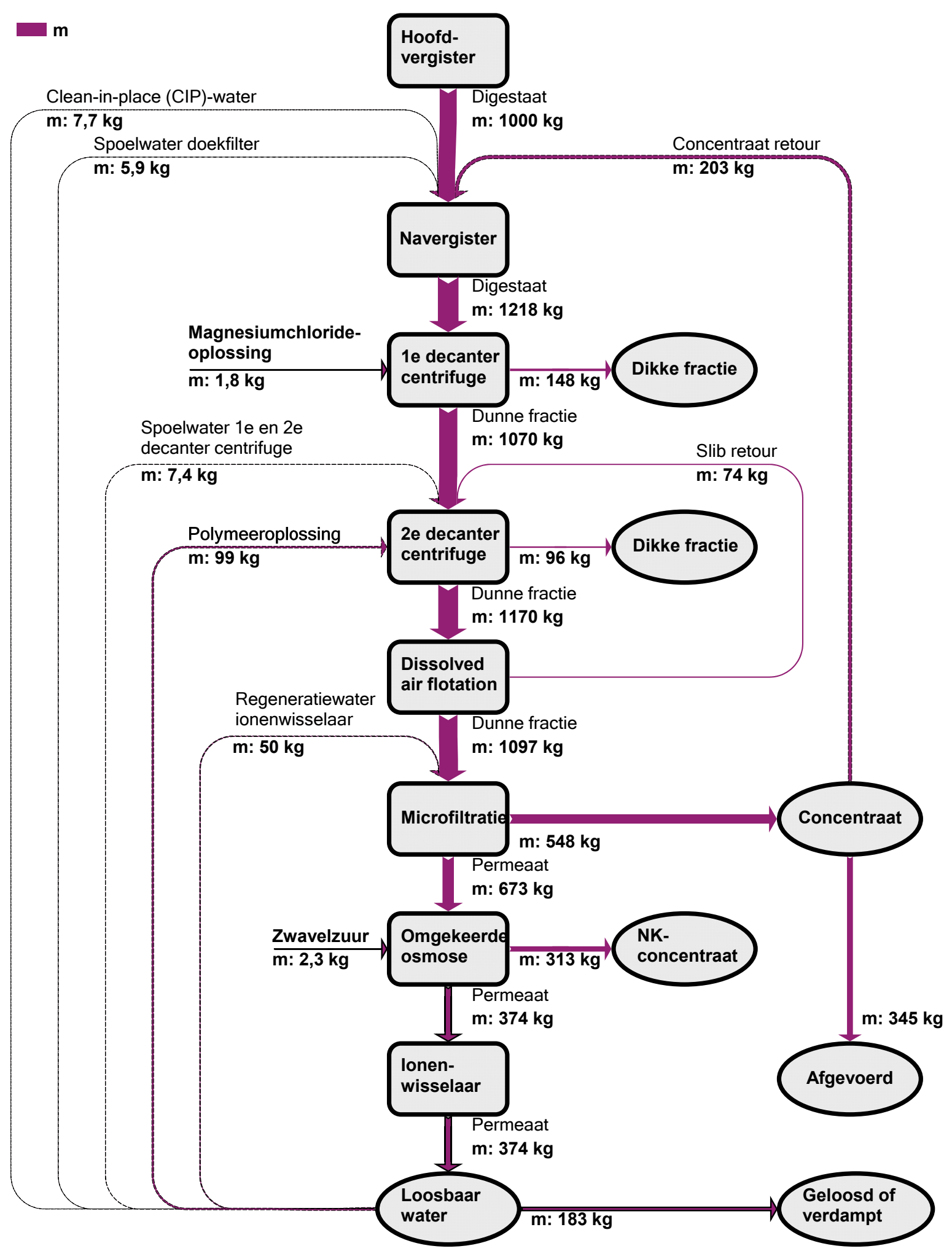

Figuur 3.2 Sankey-diagram van de totale massa $(m)$ per $1000 \mathrm{~kg}$ verwerkt digestaat van het GENIAAL-systeem van de digestaatverwerkingsinstallatie van Groot Zevert Vergisting op basis van gemeten en berekende debieten zonder uitbalancering; daarom is de som van uitgaande stromen niet precies gelijk aan de som van ingaande stromen.

De massabalans is vanwege retourstromen die terug naar de navergister worden gevoerd, opgesteld per $1000 \mathrm{~kg}$ digestaat uit de hoofdvergister. Alleen voor de microfiltratie is de som van de in- en uitgaande stromen niet grofweg aan elkaar gelijk. Deze is $8 \%$ groter voor de uitgaande stromen door onnauwkeurigheden in de gemeten debieten, omdat debietmeters een foutmarge hebben. 
Elke $1000 \mathrm{~kg}$ verwerkt digestaat resulteert in $148 \mathrm{~kg}$ dikke fractie van de eerste decanter centrifuge, $96 \mathrm{~kg}$ dikke fractie van de tweede decanter centrifuge, $345 \mathrm{~kg}$ afgevoerd concentraat van de microfiltratie en $313 \mathrm{~kg} \mathrm{NK}$-concentraat en $183 \mathrm{~kg}$ loosbaar water dat geloosd wordt of verdampt. Voor de toegevoegde polymeeroplossing is de aanname gemaakt dat de dichtheid gelijk is aan $1 \mathrm{~kg} / \mathrm{L}$, aangezien het in volume-eenheden gedoseerd en gelogd wordt.

De massa van de eindproducten uit één ton digestaat uit de hoofdvergister bedraagt tezamen $1085 \mathrm{~kg}$. Dit is de massa op basis van de debietmetingen van de flowmeters zonder uitbalancering. De flowmeters geven daarmee circa $8 \%$ overschatting van de werkelijke afvoer omdat de som van de eindproducten niet hoger zou kunnen zijn dan $1000 \mathrm{~kg}$ plus de massa van chemiedoseringen ( $5,6 \mathrm{~kg}$ voor de $\mathrm{MgCl}_{2}$-oplossing, polymeerpoeder, zwavelzuur, antischuimmiddel en antiscalant). Het loosbare water wat is toegevoegd als oploswater voor het maken van de polymeeroplossing draagt niet bij aan deze extra $85 \mathrm{~kg}$ omdat dit intern hergebruik van loosbaar water is. Hetzelfde geldt voor de andere getoonde interne hergebruiksstromen van het loosbare water.

De massa van de dikke fracties, het NK-concentraat en het afgevoerde concentraat van de MF bedraagt samen $902 \mathrm{~kg}$ per ton digestaat uit de hoofdvergister. De per as te transporteren massa is dus met circa $10 \%$ verlaagd ten opzichte van het ingaande digestaat. De $313 \mathrm{~kg}$ NK-concentraat wordt echter als kunstmestvervanger afgezet in de regio wat, voor de locatie waar GZV gelegen is, een transportwinst oplevert ten opzichte van een scenario waarin ongescheiden digestaat of dunne fractie van digestaat wordt afgezet. Ook de $148 \mathrm{~kg}$ dikke fractie van de tweede decanter centrifuge en de $345 \mathrm{~kg}$ concentraat van de MF worden binnen Nederland afgezet, hetgeen ook transportwinst oplevert. 


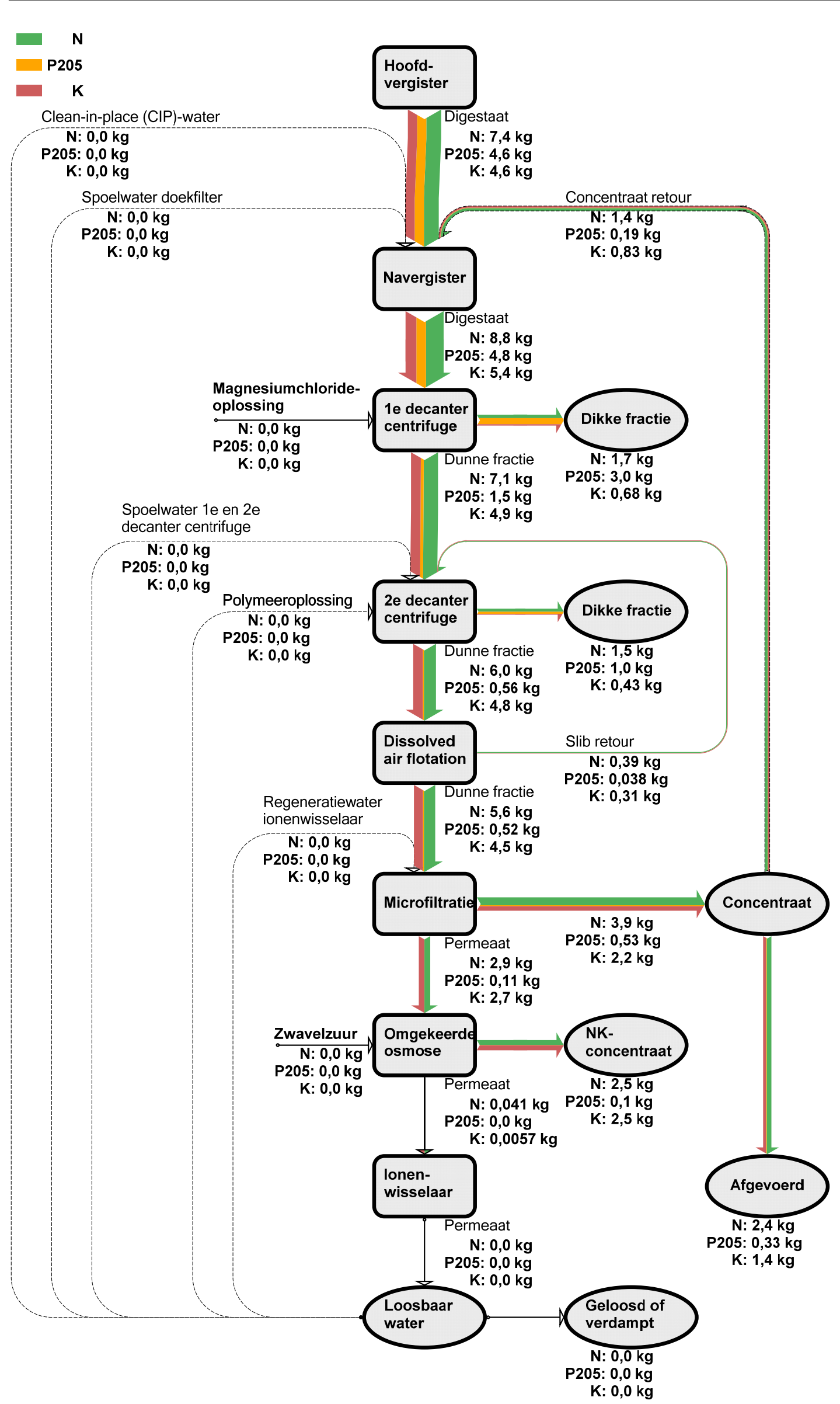

Figuur 3.3 Sankey-diagram van de massa totaal stikstof $(N)$, totaal fosfaat $\left(P_{2} O_{5}\right)$ en totaal kalium (K) per $1000 \mathrm{~kg}$ verwerkt digestaat van het GENIAAL-systeem van de digestaatverwerkingsinstallatie van Groot Zevert Vergisting op basis van gemeten en berekende debieten, vermenigvuldigd met gemeten concentraties zonder uitbalancering, daarom is de som van uitgaande stromen niet precies gelijk aan de som van ingaande stromen. 
In Figuur 3.3 is te zien dat van het ingaande fosfaat en de stikstof respectievelijk circa $60 \%$ en $20 \%$ in de dikke fractie van de eerste decanter centrifuge terechtkomen. De retourstromen die boven in de figuur zijn aangegeven, zijn niet bemonsterd. Voor die stromen is de aanname gemaakt dat ze geen nutriënten bevatten (behalve voor het regeneratiewater, daarvan is de samenstelling berekend). De som van de nutriënten voor de DAF en de MF wijken voor $\mathrm{N}$ en $\mathrm{K}$ behoorlijk af van $100 \%$. Dit komt hoogstwaarschijnlijk doordat het DAF-slib lastig op een representatieve manier te bemonsteren is. Eventueel zou het er ook aan kunnen liggen dat de samenstelling van het regeneratiewater berekend is in plaats van gemeten.

Tabel 3.6 toont de berekende massabalans per $1000 \mathrm{~kg}$ verwerkt digestaat van de mestverwerkingsinstallatie GENIAAL. Het totaal aan eindproducten als percentage van ingaand digestaat + chemie inclusief bijbehorend extern oploswater, ligt voor de meeste componenten in de buurt van de $100 \%$, behalve voor zwavel. Dat dit voor zwavel niet zo is, zou de volgende oorzaken kunnen hebben: de toegevoegde hoeveelheid zwavelzuur is niet gemeten, maar is berekend als sluitpost over de in- en uitgaande stromen van de RO. Daarnaast zijn er verliezen door vervluchtiging van waterstofsulfide en/of kleine organische zwavelverbindingen, mogelijk mercaptanen, in de ontgassingstoren welke is aangesloten op een luchtbehandeling.

Tabel 3.6 Massabalans van het GENIAAL-systeem van de digestaatverwerkingsinstallatie van Groot Zevert Vergisting in $\mathrm{kg}$ per ton ingaand digestaat, gemiddelde van vijf bemonsteringen. ${ }^{1}$

\begin{tabular}{|c|c|c|c|c|c|c|c|c|}
\hline $\begin{array}{l}\text { Para- } \\
\text { meter }\end{array}$ & $\begin{array}{l}\text { Digestaat } \\
2 \\
(\mathrm{~kg})\end{array}$ & $\begin{array}{l}\text { Chemie }^{3} \\
(\mathrm{~kg})\end{array}$ & $\begin{array}{l}\text { Dikke fractie } 1^{\mathrm{e}} \\
\text { decanter } \\
\text { centrifuge }(\mathbf{k g})\end{array}$ & $\begin{array}{l}\text { Dikke fractie } 2^{\mathrm{e}} \\
\text { decanter } \\
\text { centrifuge }(\mathrm{kg})\end{array}$ & $\begin{array}{l}\text { MF-concentraat } \\
\text { afgevoerd }(\mathbf{k g})\end{array}$ & $\begin{array}{l}\text { NK- } \\
\text { concentraat } \\
(\mathrm{kg})\end{array}$ & $\begin{array}{l}\text { Geloosd } \\
\text { water } \\
(\mathrm{kg})\end{array}$ & $\begin{array}{l}\text { Totaal } \\
\text { eind- } \\
\text { producten } \\
4(\%)\end{array}$ \\
\hline Massa & 1000 & 5,6 & 148 & 96 & 345 & 313 & 183 & 108 \\
\hline DS & 89 & & 46 & 19 & 17 & 11 & & 105 \\
\hline $\mathrm{P}_{2} \mathrm{O}_{5}$ & 4,6 & & 3,0 & 1,0 & 0,33 & 0,10 & & 97 \\
\hline $\mathrm{N}$ & 7,4 & & 1,7 & 1,5 & 2,4 & 2,5 & 0,00005 & 110 \\
\hline $\mathrm{N}-\mathrm{NH}_{4}$ & 5,2 & & 1,0 & 0,48 & 1,4 & 2,5 & 0,00004 & 104 \\
\hline $\mathrm{S}$ & 0,69 & 0,85 & 0,27 & 0,24 & 0,20 & 0,45 & 0,00054 & 77 \\
\hline $\mathrm{Fe}$ & 0,21 & 0,14 & 0,10 & 0,19 & 0,030 & 0,0022 & & 94 \\
\hline \multicolumn{9}{|c|}{$\begin{array}{l}1 \text { Massa: totale massa van processtroom per ton verwerkt digestaat uit de hoofdvergister, DS: droge stof, OS: organische stof, n.g.: niet } \\
\text { geanalyseerd. }\end{array}$} \\
\hline \multicolumn{9}{|c|}{$\begin{array}{l}2 \text { Digestaat uit de hoofdvergister: berekend als digestaat uit de navergister minus retourstromen naar de navergister en minus voor de eerste } \\
\text { decanter centrifuge toegevoegde } \mathrm{MgCl}_{2} \text {-oplossing. }\end{array}$} \\
\hline \multicolumn{9}{|c|}{$\begin{array}{l}3 \text { Chemie: totale toegevoegde massa (exclusief in GENIAAL hergebruikt water en retourstromen naar de navergister) aan } \mathrm{MgCl}_{2} \text {-oplossing, } \\
\text { polymeerpoeder, ijzersulfaat (voor een van de vijf bemonsteringsrondes) en zwavelzuur. Aangenomen is dat het polymeerpoeder } \\
\text { verwaarloosbare gehalten bevat van alle getoonde parameters omdat de samenstelling ervan onbekend is. }\end{array}$} \\
\hline \multicolumn{9}{|c|}{$\begin{array}{l}4 \text { Als percentage van digestaat uit de hoofdvergister plus toegevoegde chemie (exclusief in GENIAAL hergebruikt water en retourstromen naar } \\
\text { de navergister). }\end{array}$} \\
\hline
\end{tabular}

\subsubsection{Chemie- en energieverbruik}

Gemiddeld over de vijf bemonsteringen werd 1,4 liter (1,8 kg) $32 \% \mathrm{MgCl}_{2}$-oplossing, oftewel 0,58 $\mathrm{kg}$ $\mathrm{MgCl}_{2}$ toegevoegd per ton verwerkt digestaat uit de hoofdvergister. Ook werd gemiddeld $99 \mathrm{~kg}$ polymeeroplossing $(0,29 \mathrm{~kg}$ poeder) toegevoegd per ton verwerkt digestaat uit de hoofdvergister. De gezamenlijke zwavelzuurdosering van beide RO's is berekend op circa 1,3 liter (2,3 kg) $96 \%$ zwavelzuur $(0,73 \mathrm{~kg}$ zwavel) per ton verwerkt digestaat uit de hoofdvergister.

Het elektriciteitsverbruik van de mestverwerkingsfabriek van GZV, inclusief vergister, biogasontzwaveling, biogascompressoren, het GENIAAL-systeem en het RePeat-systeem en kantoren, bedroeg 3,79 GWh voor het jaar 2020. Op basis van een 24 uur durende verbruiksmeting is het 
elektriciteitsverbruik van het GENIAAL-systeem geschat op circa 1,7 GWh per jaar. Dat komt neer op circa $21 \mathrm{kWh}$ per ton verwerkt digestaat uit de hoofdvergister.

Voor de hygiënisatie werd in 2020 geen externe energiebron gebruikt. Dit werd in de navergister gedaan met restwarmte van de biogasmotoren met eventuele bijstook van biogas in de biogasketel. Van de in 2020 circa 3,65 GWh geproduceerde te benutten restwarmte werd 1,55 GWh gebruikt voor het verwarmen van de vergisters, circa 1,2 GWh voor hygiënisatie in de navergisters en in totaal 0,91 GWh voor verwarming van de bedrijfsgebouwen en ontzwaveling van het biogas.

\subsection{Groot Zevert Vergisting - RePeat}

\subsubsection{Algemene beschrijving}

Bij de verwerking van digestaat in het GENIAAL-systeem produceert GZV een dikke fractie met een hoog fosfaatgehalte van circa $20 \mathrm{~g} \mathrm{P}_{2} \mathrm{O}_{5} / \mathrm{kg}$. Deze wordt afgezet in West-Duitsland waarvoor transport over een afstand van circa $250-300 \mathrm{~km}$ nodig is. Vanwege de grote volumes aan dikke fractie is dit een inefficiënte en ook dure wijze van fosfaatexport. In 2015 bedroegen de afzetkosten voor de gehygiëniseerde dikke fractie $€ 25$ per ton. De markt is echter in de laatste jaren snel veranderd en door dalende prijzen voor mestafzet daalden ook de afzetkosten voor de dikke fractie. In 2020 betaalde GZV circa $€ 20$ per ton voor afzet van de dikke fractie inclusief bemonsterings- en transportkosten.

De dikke fractie bestaat op drogestofbasis voor circa $77 \%$ uit organische stof, wat waarde heeft bij gebruik als bodemverbeteraar. Om de dikke fractie ook geschikt te maken voor andere toepassingen, is verlaging van het fosfaatgehalte nodig. Het RePeat-systeem is ontwikkeld met als doel om een bodemverbeteraar met een laag fosfaatgehalte te produceren die in de regio van GZV kan worden toegepast voor extra aanvoer van organische stof op zandgronden. Het spoelproces van RePeat verwijdert niet alleen fosfaat, maar ook fijne deeltjes. Daardoor ontstaat een vezelrijk en geurloos product, dat zich ook goed leent voor andere, hoogwaardigere toepassingen als veenvervanger in potgrond of als dekaarde voor substraat voor de teelt van paddenstoelen. Beide afzetroutes zijn perspectiefvol en worden in andere projecten verder ontwikkeld.

Het fosfaat wordt separaat teruggewonnen als een fosfaatprecipitaat. In 2020 produceerde GZV dit fosfaatprecipitaat in de vorm van een verpompbaar fosfaatslib waardoor de doelstelling om het te exporteren volume terug te dringen, niet werd gerealiseerd. Het doel is om door verdere ontwatering of door dosering van magnesium in plaats van calcium, de ontwatering van het fosfaatprecipitaat te verbeteren zodat het geschikt wordt voor langeafstandstransport. Een mogelijke afzetroute is als grondstof voor organische gekorrelde meststoffen. Op dit moment is de productie aan fosfaatslib nog beperkt en wordt het slib door GZV afgezet bij akkerbouwers in Nederland. Het fosfaat dat op deze wijze wordt afgezet, telt niet mee voor de fosfaatverwerkingsplicht maar er is, mede door het dalende fosfaatoverschot in de Nederlandse landbouw, voldoende vraag naar.

\subsubsection{Technische procesbeschrijving}

Figuur 3.4 toont het processtroomdiagram van het systeem 'RePeat' van GZV. De dikke fractie van digestaat wordt aangevoerd met een transportband en daarna in een mixer gemengd met verdunningswater tot een verpompbare stroom, waarna het naar een mengtank gaat. De $\mathrm{pH}$ in de mengtank wordt op pH 5,5 gehouden door dosering van 98\% zwavelzuur. De gemiddelde verblijftijd in de mengtank is circa twee uur en dit is ruim voldoende om het fosfaat in oplossing te brengen. De inhoud van de mengtank wordt semi-continu afgepompt naar de eerste schroefpers. Scheiding door de schroefpers resulteert in een zure, fosfaatrijke oplossing en een dikke fractie met een verlaagd fosfaatgehalte. De dikke fractie wordt nogmaals op-gemengd in een mixer met verdunningswater. Het verdunningswater is het effluent van de fosfaatbezinker verderop in het proces. Het heeft daardoor ten opzichte van de rest van de processtromen een relatief laag fosfaatgehalte van circa $0,5 \mathrm{~g}$ $\mathrm{P}_{2} \mathrm{O}_{5} / \mathrm{kg}$. Door dosering van zwavelzuur wordt de $\mathrm{pH}$ van dit verdunningswater voorafgaand aan opmenging met de dikke fractie verlaagd naar circa pH 5,5. De tweede schroefpers scheidt dit mengsel 
daarna in een dunne fractie, die wordt gebruikt als verdunningswater in de mengtank voor de eerste schroefpers, en een fosfaatarme bodemverbeteraar. De zure fosfaatrijke dunne fractie van de eerste schroefpers wordt via een lamellenbezinker ontdaan van een deel van de particulaire organische stof die het bevat en gaat daarna naar de fosfaatprecipitatietank. Daar wordt de $\mathrm{pH}$ door toevoeging van kalkmelk (suspensie van calciumhydroxide) verhoogd tot circa 6,5 à 7 om het opgeloste fosfaat neer te slaan. De toegevoegde kalkmelk dient primair als base; het influent van de fosfaatprecipitatietank bevat namelijk al voldoende calcium (circa 2,5 g Ca/kg) en magnesium (circa 2,4 g Mg/kg) om het fosfaat te laten precipiteren als calcium- en magnesiumfosfaten, mits de $\mathrm{pH}$ hiervoor voldoende hoog is. De kalkmelk wordt ingekocht als een suspensie met een drogestofgehalte van $45 \%$ en wordt opgeslagen in een continu geroerde tank. GZV heeft in 2021 een voorziening gemaakt waarmee ook vaste kalkpoeders met water gemengd kunnen worden zonder stofvorming. Tot nu toe heeft de fosfaatprecipitatietank alleen gedraaid met toevoeging van kalkmelk en zijn nog geen testen uitgevoerd met toevoeging van magnesiumhydroxide i.p.v. kalkmelk. Toevoeging van magnesiumhydroxide stimuleert de vorming van struviet $\left(\mathrm{Mg}\left(\mathrm{NH}_{4}\right) \mathrm{PO}_{4} \cdot 6\left(\mathrm{H}_{2} \mathrm{O}\right)\right.$, wat de eigenschap heeft om via kristalvorming grovere deeltjes te vormen. Door de grovere deeltjes is het gevormde fosfaatslib beter ontwaterbaar dan bij vorming van calciumfosfaat, wat juist resulteert in een melkachtige suspensie. Dit blijkt ook uit eerdere lab- en pilottesten uitgevoerd in het kader van dit project (Regelink et al., 2018). Het systeem is ontworpen om groei van struviet te stimuleren door slib onder uit de fosfaatbezinker te recirculeren naar de fosfaatprecipitatietank. GZV wil echter geen magnesiumhydroxide toevoegen vanwege het risico op struvietvorming in de leidingen. Dit vanwege negatieve ervaringen met schade door struvietvorming in het GENIAAL-systeem. Een consequentie hiervan is dat het fosfaatprecipitaat in de vorm van een verpompbaar slib wordt geproduceerd i.p.v. als het geplande steekvaste product.

De installatie is begin 2020 opgestart waarna problemen door emissies van $\mathrm{H}_{2} \mathrm{~S}$ bij o.a. de schroefpersen en mengtanks ontstonden. Ook het aanzuren zelf kan emissies van $\mathrm{H}_{2} \mathrm{~S}$ in gang zetten, omdat het in de vloeistof aanwezige bicarbonat $\left(\mathrm{HCO}_{3}{ }^{-}\right)$door een verschuiving in het chemisch evenwicht dan in de vorm van het gas koolstofdioxide $\left(\mathrm{CO}_{2}\right)$ ontsnapt. Andere gassen, zoals $\mathrm{H}_{2} \mathrm{~S}$, kunnen door de ontsnappende $\mathrm{CO}_{2}$ uit de vloeistof gestript worden. Ook veroorzaakt aanzuren een verschuiving van het chemisch evenwicht van $\mathrm{HS}^{-}$naar $\mathrm{H}_{2} \mathrm{~S}$. Om deze problemen te ondervangen, zijn alle voorheen open tanks en alle schroefpersen voorzien van een afdekking met luchtafzuiging. Ook is meer ventilatie aangebracht om ophoping van $\mathrm{H}_{2} \mathrm{~S}$ in de hoeken van de proceshal te voorkomen. $\mathrm{H}_{2} \mathrm{~S}$ is zwaarder dan lucht en kan daarom onder in de hal ophopen, wat tot verraderlijke situaties leidt. 


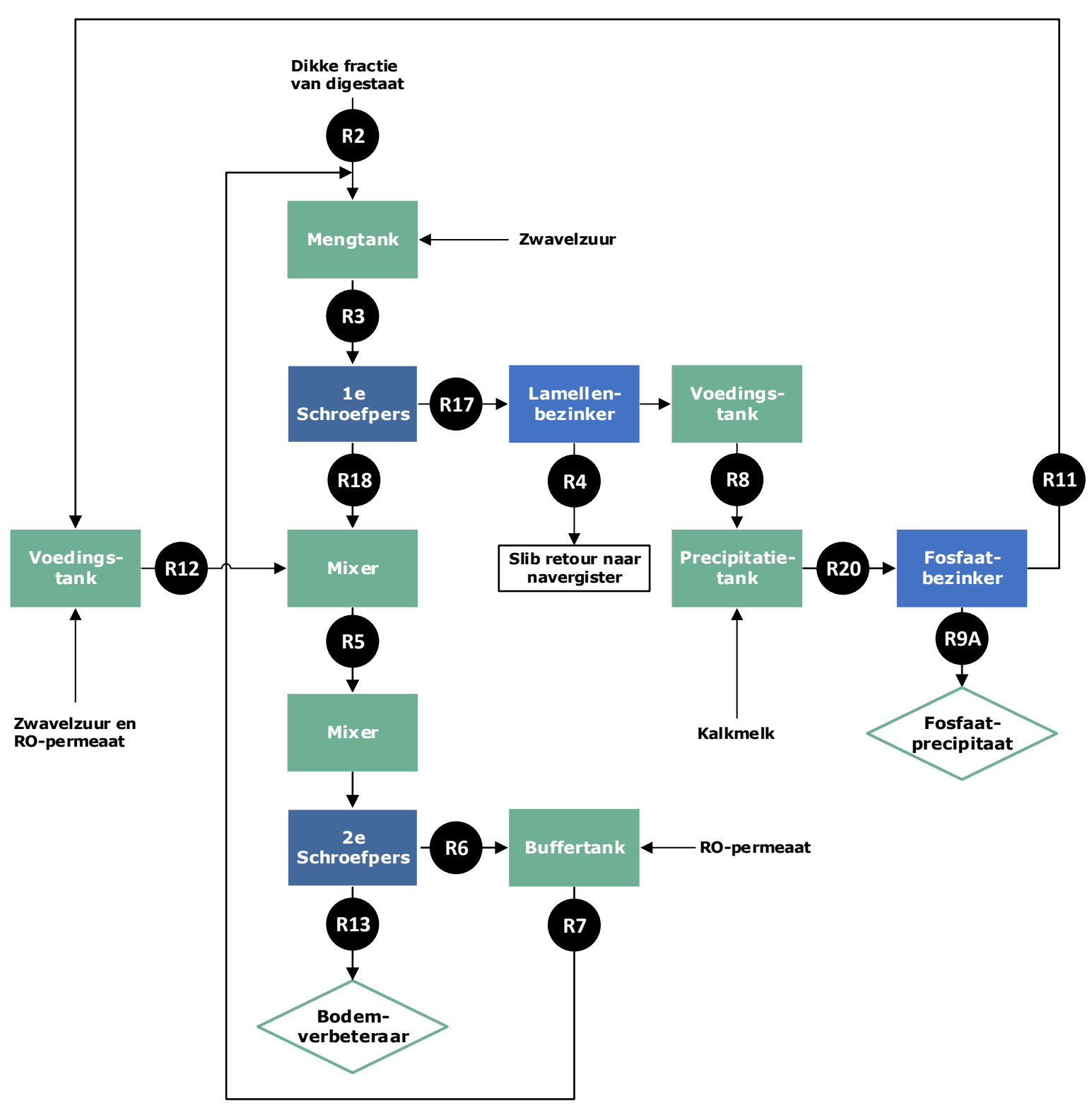

Figuur 3.4 Processtroomdiagram van het RePeat-systeem van de digestaatverwerkingsinstallatie van Groot Zevert Vergisting; bemonsteringspunten zijn aangegeven met een letternummercombinatie.

\subsubsection{Scheidingsrendementen}

\subsubsection{Eerste zuurdosering en schroefpers}

Tabel 3.7 geeft de samenstelling van de in- en uitgaande stromen en de berekende scheidingsrendementen van de eerste aanzuur- en scheidingsstap. De dikke fractie wordt op-gemengd met verdunningswater, waarna zwavelzuur wordt toegevoegd. Het verdunningswater is de dunne fractie van de tweede spoelstap en is daarom al zuur en bevat fosfaat. Het aangezuurde mengsel wordt door de eerste schroefpers gescheiden in een dikke en dunne fractie. Hierbij gaat het fosfaat voor $76 \%$ naar de dunne fractie. Daardoor heeft de gevormde dikke fractie een laag fosfaatgehalte van $8 \mathrm{~g} \mathrm{P}_{2} \mathrm{O}_{5} / \mathrm{kg}$ t.o.v. de initiële dikke fractie afkomstig uit het GENIAAL-systeem ( $23 \mathrm{~g} \mathrm{P}_{2} \mathrm{O}_{5} / \mathrm{kg}$ ). De schroefpers laat relatief veel organische stof door; circa 39\% van de ingaande organische stof gaat naar de dunne fractie. Het scheidingsrendement van een schroefpers is daarmee lager dan dat van een decanter centrifuge of zeefbandpers, waarmee fijne organische deeltjes beter worden afgescheiden. 
Tabel 3.7 Samenstelling van de in- en uitgaande stromen van de eerste zuurdosering en schroefpers van Groot Zevert Vergisting en het berekende scheidingsrendement als percentage van het influent. Gemiddelde van één bemonstering. ${ }^{1}$

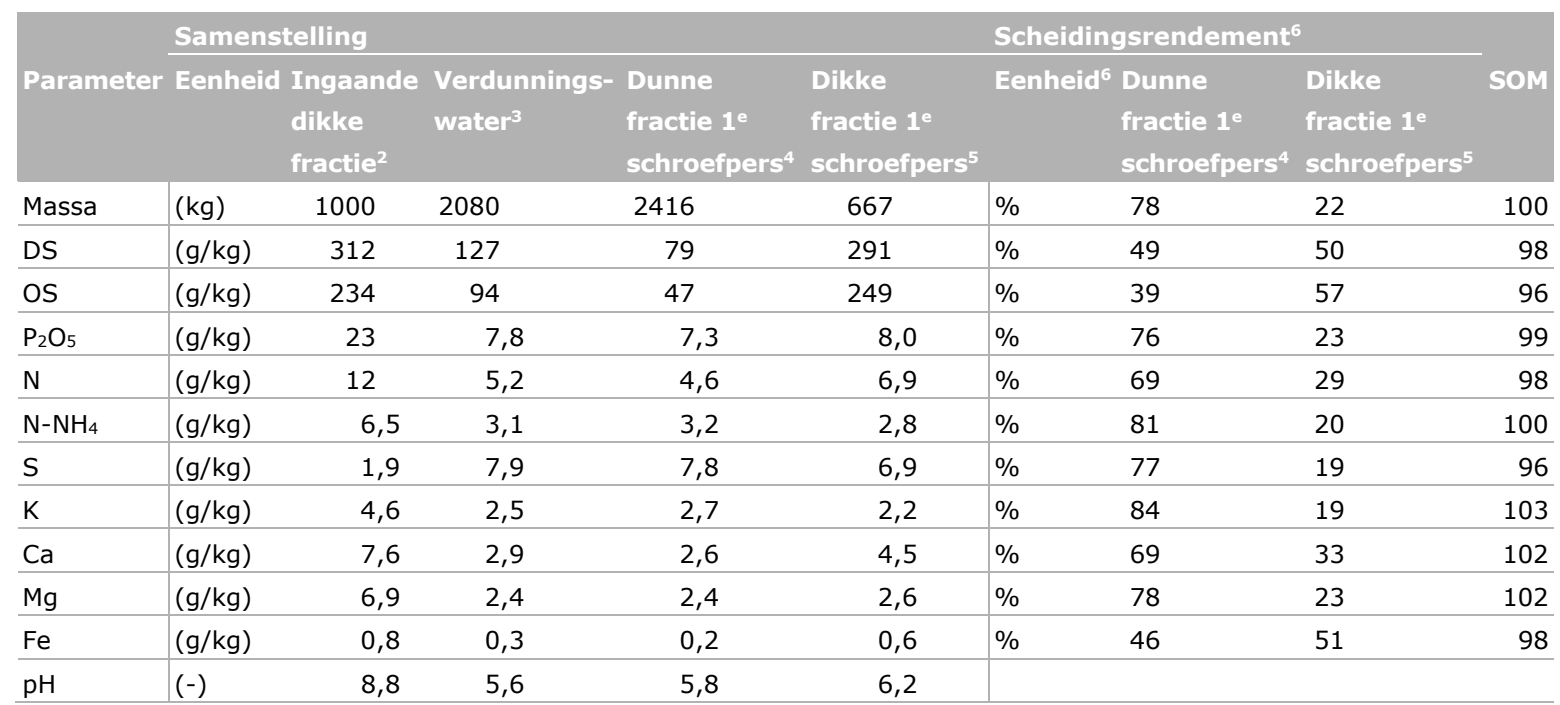

1 Massa: totale massa van processtroom per ton ingaande dikke fractie van digestaat uit het GENIAAL-systeem, DS: droge stof, OS: organische stof.

2 Dikke fractie van de eerste decanter centrifuge van het GENIAAL-systeem van Groot Zevert Vergisting (bemonsteringspunt R1).

3 Verdunningswater bestaande uit dunne fractie van de tweede schroefpers aangevuld met omgekeerde osmose-permeaat (bemonsteringspunt R7).

4 Fosfaatrijke dunne fractie van de eerste schroefpers (bemonsteringspunt R18).

5 Fosfaatarme dikke fractie van de eerste schroefpers (bemonsteringspunt R17).

6 Percentage t.o.v. de ingaande massa (inclusief verdunningswater en toegevoegde chemie en bijbehorend oploswater).

\subsubsection{Lamellenbezinker}

De zure dunne fractie van de eerste schroefpers met daarin het opgeloste fosfaat wordt over een lamellenbezinker geleid voor verwijdering van een deel van de organische stof en andere deeltjes. Tabel 3.8 geeft de samenstelling van de in- en uitgaande stromen van de lamellenbezinker. Bij de verwerking van één ton initiële dikke fractie, ontstaat circa $2416 \mathrm{~kg}$ aangezuurde dunne fractie. Op basis van de debietmeters is afgeleid dat $2416 \mathrm{~kg}$ dunne fractie door de lamellenbezinker wordt gescheiden in $393 \mathrm{~kg}$ slib en $2024 \mathrm{~kg}$ effluent. $\mathrm{Er}$ is echter geen meetbaar verschil in samenstelling tussen het slib en het effluent van de lamellenbezinker, ondanks dat tijdens bemonstering visueel wel werd vastgesteld dat het slib een hogere viscositeit heeft dan het effluent. Wellicht wordt dit deels veroorzaakt door het nemen van niet-representatieve monsters. Het slib van de lamellenbezinker wordt bijvoorbeeld pulsgewijs afgelaten en net na het openen van de klep is het slib dikker dan enkele seconden later. $\mathrm{Er}$ is echter ook geen duidelijk verschil in samenstelling tussen het effluent van de lamellenbezinker en de ingaande zure dunne fractie. De resultaten zijn onzeker, maar ze wijzen erop dat de lamellenbezinker niet of nauwelijks organische stof afscheidt. Daarom is geen scheidingsrendement berekend. Het slib wordt gemengd afgezet met het MF-concentraat van het GENIAAL-systeem. 
Tabel 3.8 Samenstelling van de in- en uitgaande stromen van de lamellenbezinker van Groot Zevert Vergisting. Gemiddelde van vier bemonsteringen. ${ }^{1}$

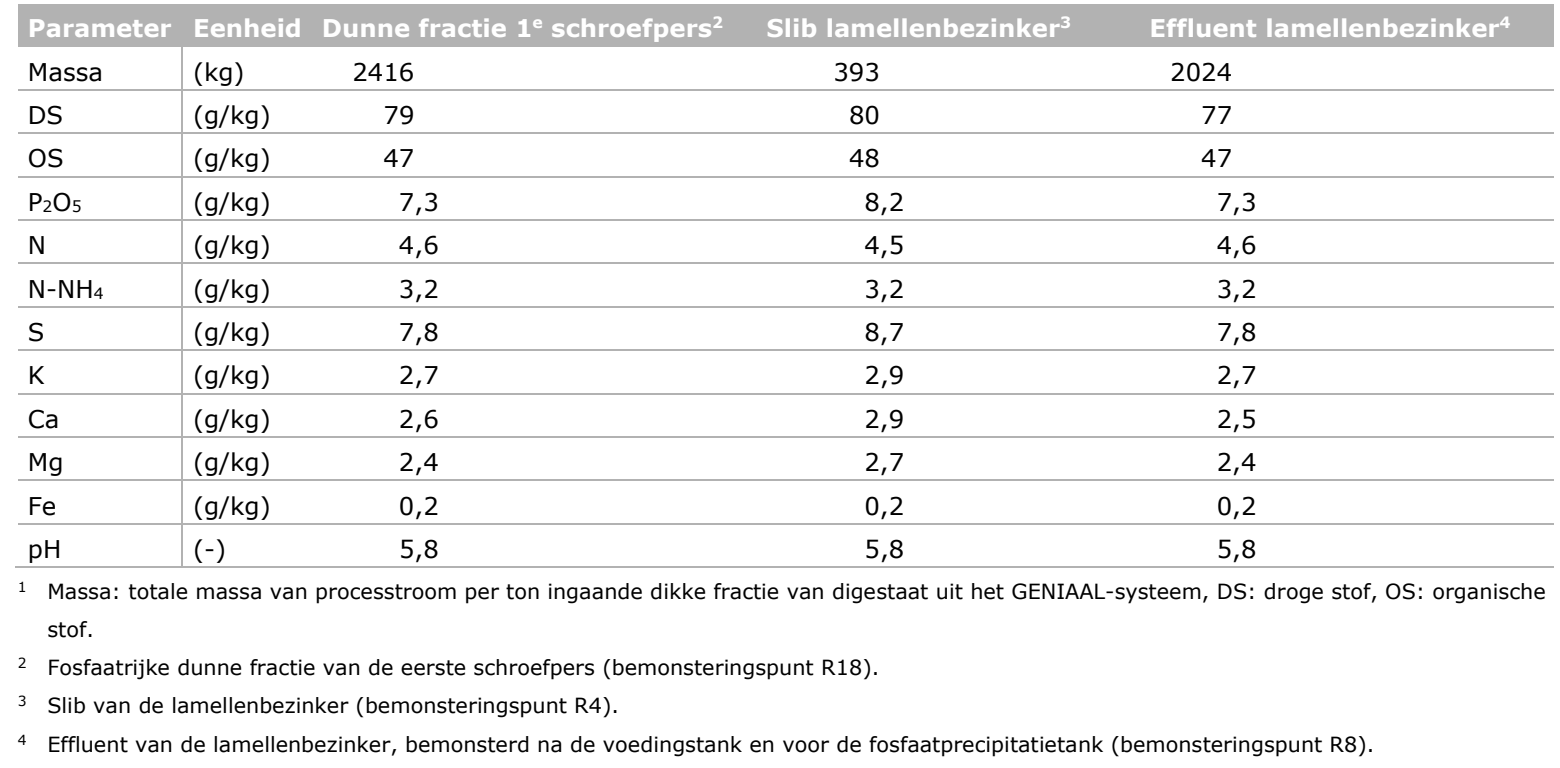

\subsubsection{Fosfaatprecipitatietank en fosfaatbezinker}

Het effluent van de lamellenbezinker (Tabel 3.9) wordt in de fosfaatprecipitatietank gepompt, waar kalkmelk wordt gedoseerd om fosfaat te laten precipiteren. Na bezinking resulteert dit in een fosfaatslib met een drogestofgehalte van circa $19 \%$ en een fosfaatgehalte van $27 \mathrm{~g} \mathrm{P} \mathrm{O}_{5} / \mathrm{kg}$. Het effluent van de fosfaatbezinker bevat slechts $0,5 \mathrm{~g} \mathrm{P}_{2} \mathrm{O}_{5} / \mathrm{kg}$, wat aangeeft dat de bezinker goed functioneert.

Het bleek lastig om het fosfaatslib op een representatieve manier te bemonsteren, omdat het slib in de opslagcontainer uitzakt waardoor onder in de container een vast, moeilijk roerbaar precipitaat ontstond. Daarom is besloten het fosfaatslib ook tijdens het pulsgewijze afpompen van de fosfaatbezinker - in de afvoerleiding naar de opslagcontainer - te bemonsteren, wat monsters met hogere drogestofgehalten opleverde. Deze laatst beschreven monsters zijn gebruikt voor het opstellen van de massabalans. 
Tabel 3.9 Samenstelling van de in- en uitgaande stromen van de fosfaatprecipitatietank en nageschakelde fosfaatbezinker en het berekende scheidingsrendement als percentage van het influent. Gemiddelde van vier bemonsteringen. ${ }^{1}$

\begin{tabular}{|c|c|c|c|c|c|c|c|c|}
\hline \multirow[b]{2}{*}{ Parameter } & \multicolumn{4}{|c|}{ Samenstelling } & \multicolumn{4}{|c|}{ Scheidingsrendement ${ }^{6}$} \\
\hline & Eenheid & $\begin{array}{l}\text { Influent } \\
\text { precipitatie- } \\
\text { tank }^{2}\end{array}$ & Fosfaatslib ${ }^{3}$ & $\begin{array}{l}\text { Effluent } \\
\text { fosfaat- } \\
\text { bezinker }{ }^{4}\end{array}$ & Eenheid ${ }^{5}$ & $\begin{array}{l}\text { Fosfaat- } \\
\text { slib }^{3}\end{array}$ & $\begin{array}{l}\text { Effluent } \\
\text { fosfaat- } \\
\text { bezinker }{ }^{4}\end{array}$ & SOM \\
\hline Massa & $(\mathrm{kg})$ & 2024 & 512 & 1762 & $\%$ & 25 & 87 & 116 \\
\hline DS & $(\mathrm{g} / \mathrm{kg})$ & 77 & 188 & 35 & $\%$ & 56 & 40 & 95 \\
\hline $\mathrm{P}_{2} \mathrm{O}_{5}$ & $(\mathrm{~g} / \mathrm{kg})$ & 7,3 & 27 & 0,5 & $\%$ & 85 & 6 & 91 \\
\hline $\mathrm{N}$ & $(\mathrm{g} / \mathrm{kg})$ & 4,6 & 8,4 & 3,0 & $\%$ & 44 & 57 & 101 \\
\hline $\mathrm{N}-\mathrm{NH}_{4}$ & $(\mathrm{~g} / \mathrm{kg})$ & 3,2 & 4,3 & 2,3 & $\%$ & 39 & 63 & 102 \\
\hline $\mathrm{S}$ & $(\mathrm{g} / \mathrm{kg})$ & 7,8 & 8,8 & 4,9 & $\%$ & 30 & 55 & 85 \\
\hline $\mathrm{Fe}$ & $(\mathrm{g} / \mathrm{kg})$ & 0,2 & 0,2 & 0,1 & $\%$ & 82 & 44 & 126 \\
\hline $\mathrm{pH}$ & $(-)$ & 5,8 & 7,2 & 7,7 & & & & \\
\hline
\end{tabular}

1 Massa: totale massa van processtroom per ton ingaande dikke fractie van digestaat uit het GENIAAL-systeem, DS: drogestof, OS: organische stof.

2 Effluent van de lamellenbezinker, bemonsterd na de voedingstank en voor de fosfaatprecipitatietank (bemonsteringspunt R8).

3 Fosfaatslib afgetapt via kraantje aan de zijkant van de conus van de fosfaatbezinker (bemonsteringspunt R24).

4 Effluent dat aan de bovenkant uit de fosfaatbezinker stroomt (bemonsteringspunt R11).

5 Percentage t.o.v. de ingaande massa (inclusief toegevoegde chemie en bijbehorend oploswater).

\subsubsection{Massabalans}

Tabel 3.10 geeft de berekende massabalans van het RePeat-systeem per $1000 \mathrm{~kg}$ verwerkte dikke fractie van digestaat. De getoonde massabalans is die over de maand januari 2021, omdat de bemonstering in deze maand een betrouwbare massabalans gaf.

Per ton ingaande dikke fractie uit het GENIAAL-systeem werd circa $750 \mathrm{~kg}$ bodemverbeteraar, $512 \mathrm{~kg}$ fosfaatslib en $393 \mathrm{slib}$ van de lamellenbezinker geproduceerd. De massa aan eindproducten is dus circa $65 \%$ groter dan die van de ingaande dikke fractie van digestaat. Dit komt doordat het slib van de lamellenbezinker in de vorm van een waterige stroom wordt afgevoerd, waardoor aanvoer van extern water (RO-permeaat afkomstig van het GENIAAL-systeem) nodig is om de waterbalans op peil te houden. De doelstelling om het volume af te voeren product te verlagen, is daarmee (nog) niet gerealiseerd. De fosfaatscheiding is effectief, circa $60 \%$ van het fosfaat in de ingaande dikke fractie van digestaat wordt afgevoerd via het fosfaatslib, circa $10 \%$ via de bodemverbeteraar en circa $13 \%$ via het slib van de lamellenbezinker. Circa $20 \%$ van de fosfaatbalans kon niet verklaard worden, vermoedelijk door een onderschatting van het fosfaatgehalte in het fosfaatslib (of door ophoping van fosfaat onder in een van de tanks van het RePeat-systeem). 
Tabel 3.10 Massabalans van het RePeat-systeem van de digestaatverwerkingsinstallatie van Groot Zevert Vergisting in $\mathrm{kg}$ per ton ingaande dikke fractie van digestaat, gemiddelde van vier bemonsteringen. ${ }^{1}$

\begin{tabular}{|c|c|c|c|c|c|c|}
\hline Parameter 1 & $\begin{array}{l}\text { Ingaande dikke } \\
\text { fractie }^{2} \\
(\mathrm{~kg})\end{array}$ & $\begin{array}{l}\text { Chemie en } \\
\text { water }^{3} \\
(\mathbf{k g})\end{array}$ & $\begin{array}{l}\text { Slib } \\
\text { lamellenbezinker }{ }^{4} \\
\text { (kg) }\end{array}$ & $\begin{array}{l}\text { Fosfaatslib }{ }^{5} \\
\text { (kg) }\end{array}$ & $\begin{array}{l}\text { Bodemverbeteraar }{ }^{6} \\
\text { (kg) }\end{array}$ & $\begin{array}{l}\text { Totaal } \\
\text { eindproducten } \\
(\%)\end{array}$ \\
\hline DS & 312 & & 31 & 87 & 192 & 100 \\
\hline OS & 235 & & 19 & 42 & 171 & 99 \\
\hline $\mathrm{N}$ & 12 & & 1,8 & 4,1 & 4,0 & 85 \\
\hline $\mathrm{N}-\mathrm{NH}_{4}$ & 6,5 & & 1,3 & 2,5 & 1,3 & 78 \\
\hline $\mathrm{S}$ & 1,9 & 13 & 3,4 & 4,8 & 3,4 & 76 \\
\hline $\mathrm{K}$ & 4,6 & & 1,1 & 1,1 & 1,2 & 76 \\
\hline $\mathrm{Ca}$ & 7,6 & 7,8 & 1,2 & 7,6 & 2,5 & 73 \\
\hline
\end{tabular}

1 Massa: totale massa van processtroom per ton ingaande dikke fractie van digestaat uit het GENIAAL-systeem, DS: droge stof, OS: organische stof.

2 Dikke fractie van de eerste decanter centrifuge van het GENIAAL-systeem van Groot Zevert Vergisting (bemonsteringspunt R1).

3 Chemie: totale toegevoegde massa aan zwavelzuur, kalkmelk en extern verdunningswater (omgekeerde osmose-permeaat).

4 Slib van de lamellenbezinker (bemonsteringspunt R4).

5 Fosfaatslib afgetapt via kraantje aan de zijkant van de conus van de fosfaatbezinker (bemonsteringspunt R24).

6 Dikke fractie van de tweede schroefpers (bemonsteringspunt R13).

7 Als percentage van ingaande dikke fractie van digestaat uit het GENIAAL-systeem plus toegevoegde chemie.

\subsubsection{Trends in de samenstelling van de eindproducten}

De samenstelling van de eindproducten van het RePeat-systeem was over een monitoringsperiode van zeven bemonsteringsrondes nog niet volledig constant. Figuur 3.5 toont het verloop in de tijd in de samenstelling van de bodemverbeteraar en het fosfaatslib. Het fosfaatgehalte in de bodemverbeteraar fluctueerde tussen 1,8 en $7,4 \mathrm{~g} \mathrm{P}_{2} \mathrm{O}_{5} / \mathrm{kg}$, dit is een te grote spreiding om het product doorlopend als bodemverbeteraar af te kunnen zetten. Het zwavelgehalte fluctueerde tussen $2,4 \mathrm{en} 6,1 \mathrm{~g} / \mathrm{kg}$ en ook deze mate van variatie is groot, waardoor opname van de bodemverbeteraar in bemestingsplannen speciaal per vracht moet worden afgestemd. Hetzelfde geldt voor de samenstelling van het fosfaatslib; het fosfaat- en zwavelgehalte varieert in de tijd. Bij het fosfaatslib speelt daarnaast ook mee dat het materiaal moeilijk representatief te bemonsteren is. 

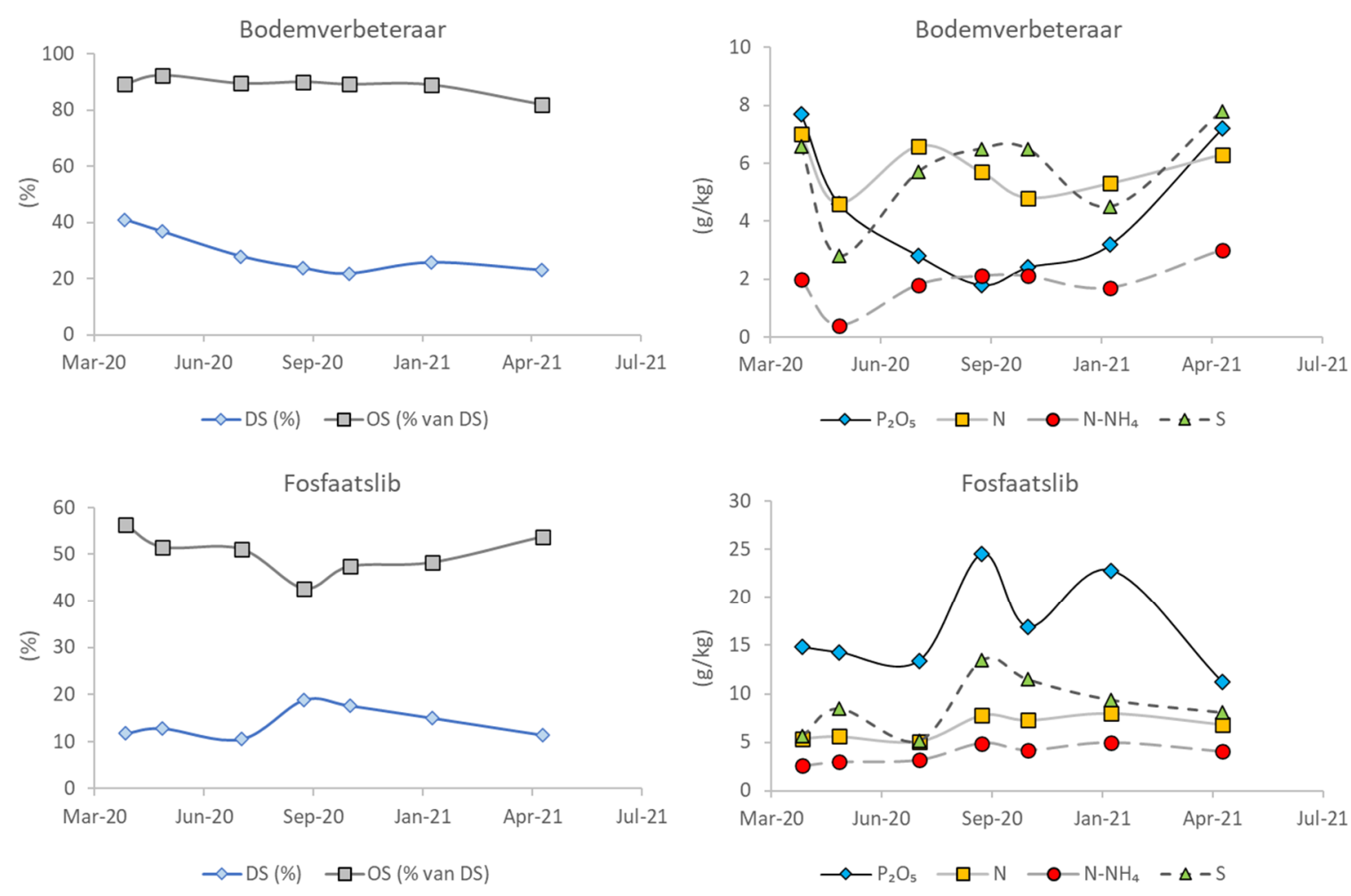

Figuur 3.5 Verloop in de tijd in het gehalte droge stof (DS), organische stof (OS), fosfaat $\left(\mathrm{P}_{2} \mathrm{O}_{5}\right)$, stikstof $(\mathrm{N})$, ammoniakale stikstof $\left(\mathrm{N}-\mathrm{NH}_{4}\right)$ en zwavel $(\mathrm{S})$ in de bodemverbeteraar en het fosfaatslib geproduceerd door het RePeat-systeem van de digestaatverwerkingsinstallatie van Groot Zevert Vergisting.

\subsubsection{Chemie- en energieverbruik}

Het RePeat-systeem verbruikt zwavelzuur voor verlaging van de $\mathrm{pH}$ om fosfaat in oplossing te brengen (Tabel 3.11). De zwavelzuurdosering voorafgaand aan beide schroefpersen is $\mathrm{pH}$-gestuurd en het zwavelzuurverbruik wordt gemonitord op basis van de pulsen van de doseerpompen. Voor beide aanzuurstappen wordt gestuurd op een $\mathrm{pH}$-waarde tussen de 5,3 en 5,8. De installatie verbruikt circa 25 liter (46 kg) 98\% zwavelzuur per ton ingaande dikke fractie. Hiervan wordt $87 \%$ verbruikt in de eerste aanzuurstap en $13 \%$ in de tweede aanzuurstap. De zwavelzuurdosering is daarnaast ook berekend op basis van het verschil in het gemeten zwavelgehalte voor en na de aanzuringen. De via de doseerpompen gemeten zwavelzuurdosering komt daar goed mee overeen.

Kalkmelk wordt toegevoegd in de fosfaatprecipitatietank om de $\mathrm{pH}$ te verhogen naar $\mathrm{pH}$, zodat fosfaat neerslaat met de aanwezige kationen (Ca en $\mathrm{Mg}$ ). De ingekochte kalkmelk wordt gemengd met water $(1: 5 \mathrm{v} / \mathrm{v})$ en de resulterende suspensie wordt opgeslagen in een continu geroerde tank. Deze verdunning is noodzakelijk om verstoppingen in het leidingwerk te voorkomen. Er wordt circa 14 tot 20 liter kalkmelk $\left(45 \% \mathrm{Ca}(\mathrm{OH})_{2}\right)$ per ton ingaande dikke fractie van digestaat gebruikt.

Tabel 3.11 Maandgemiddeld chemieverbruik van het RePeat-systeem per ton ingaande dikke fractie van digestaat voor de maanden november en december 2020 en januari 2021 .1,2 $^{2}$

\begin{tabular}{lllll} 
& & November & December & Januari \\
Zwavelzuur, $98 \% \mathrm{H}_{2} \mathrm{SO}_{4}$ & (liter/ton dikke fractie) & 28 & 25 & 26 \\
\hline Kalkmelk, $45 \% \mathrm{Ca}(\mathrm{OH})_{2}$ & (liter/ton dikke fractie) & 20 & 14 & 14 \\
\hline 1 & Sinds 15 december 2020 is de ingestelde $\mathrm{pH}$-waarde van de aanzuurtanks met 0,1 eenheid verhoogd om het zwavelzuurverbruik te \\
& verminderen. \\
2 & Dichtheid zwavelzuur: $1.8 \mathrm{~kg} / \mathrm{l}$, kalkmelk: $1.35 \mathrm{~kg} / \mathrm{l}$.
\end{tabular}


Tabel 3.12 toont het gemiddelde verbruik aan elektriciteit van het RePeat-systeem. Wanneer er geen dikke fractie van digestaat verwerkt wordt (geen draaidag), verbruikt het systeem gemiddeld $156 \mathrm{kWh}$ per dag voor o.a. het beluchten en roeren van de fosfaatprecipitatietank en verschillende kleinere tanks. De beluchting staat altijd aan om vorming van $\mathrm{H}_{2} \mathrm{~S}$ te voorkomen. In de monitoringsperiode werd de installatie op werkdagen gebruikt, waarbij gemiddeld acht ton dikke fractie per dag verwerkt werd. Op die draaidagen bedroeg het elektriciteitsverbruik gemiddeld $347 \mathrm{kWh}$ per dag, wat overeenkomt met circa $57 \mathrm{kWh}$ per ton ingaande dikke fractie. Wanneer het systeem conform ontwerp 24 uur per dag draait, zal het elektriciteitsverbruik dalen tot naar schatting $20 \mathrm{kWh}$ per ton ingaande dikke fractie (circa $€ 1,40$ per ton ingaande dikke fractie).

Tabel 3.12 Gemiddeld elektriciteitsverbruik per dag (24 uur) van de drie elektriciteitsgroepen van het RePeat-systeem en het gehele RePeat-systeem. ${ }^{1}$

\begin{tabular}{|c|c|c|c|c|}
\hline Elektriciteitsgroep & Onderdelen & Eenheid & $\begin{array}{l}\text { Draaidag } \\
\text { (installatie in } \\
\text { gebruik) }\end{array}$ & $\begin{array}{l}\text { Geen draaidag } \\
\text { (installatie in } \\
\text { stand-by) }\end{array}$ \\
\hline Groep 1 & $\begin{array}{l}\text { Eerste aanzuring (aanvoerband, } \\
\text { pomp en mixer eerste aanzuurtank) }\end{array}$ & (kWh/dag) & 94 & 47 \\
\hline Groep 2 & $\begin{array}{l}\text { Scheiding dikke fractie } \\
\text { (schroefpersen, biomix, pompen) }\end{array}$ & (kWh/dag) & 105 & 22 \\
\hline Groep 3 & $\begin{array}{l}\text { Fosfaatafscheiding (roerwerk en } \\
\text { beluchting fosfaattank, pompen) }\end{array}$ & (kWh/dag) & 147 & 87 \\
\hline Totaal & & (kWh/dag) & 347 & 156 \\
\hline
\end{tabular}

\subsection{Loonbedrijf Dekker}

\subsubsection{Algemene beschrijving}

Loonbedrijf Dekker (Dekker) is een mestverwerkingsbedrijf in Putten (Gelderland) waar jaarlijks circa 83 kton mest (40 kton varkensmest, 23 kton rosékalvermest, 15 kton ongeboren mest van varkens en runderen en 5 kton overige mest) en circa 7 kton co-producten afkomstig uit de voedselverwerkende industrie wordt verwerkt. De biogasproductie bedraagt circa 3,1 miljoen $\mathrm{Nm}^{3}$ op jaarbasis, gaswassers ontzwavelen het biogas waarna een biogasmotor het omzet in elektriciteit en (rest)warmte. Het geproduceerde digestaat wordt met een zeefbandpers gescheiden in een dikke en dunne fractie. De dikke fractie wordt gehygiëniseerd en daarna afgezet in Oost-Europa en Frankrijk. De dunne fractie wordt afgezet in de Flevopolder en buiten de bemestingsperiode opgeslagen bij afnemers. Dekker houdt de optie open om in de toekomst de installatie uit te breiden met een RO om de dunne fractie verder in te dikken. In 2020 is een DAF gerealiseerd om de dunne fractie van de zeefbandpers verder mee te behandelen. Deze is niet meegenomen in de bemonstering, omdat de DAF tijdens de bemonsteringen nog niet operationeel was.

\subsubsection{Technische procesbeschrijving}

De co-producten worden met een deel van de mest vergist voor de productie van biogas. Het andere deel van de mest wordt toegevoegd in de navergister. Het digestaat uit de navergister wordt opgeslagen in een silo en vandaaruit naar een torenmenger waaraan polymeeroplossing wordt toegevoegd. Daarna wordt het digestaat via een zeefbandpers gescheiden in een dunne en een dikke fractie. De dikke fractie wordt gehygiëniseerd bij een eindtemperatuur van 53 à $55^{\circ} \mathrm{C}$ met restwarmte van de biogasmotoren. Na hygiënisatie is het drogestofgehalte van de dikke fractie 30 à $33 \%$. Het processchema en de bemonsteringspunten zijn opgenomen in Figuur 3.6. De dikke fractie is zowel voor als na de hygiënisatie-installatie bemonsterd. 


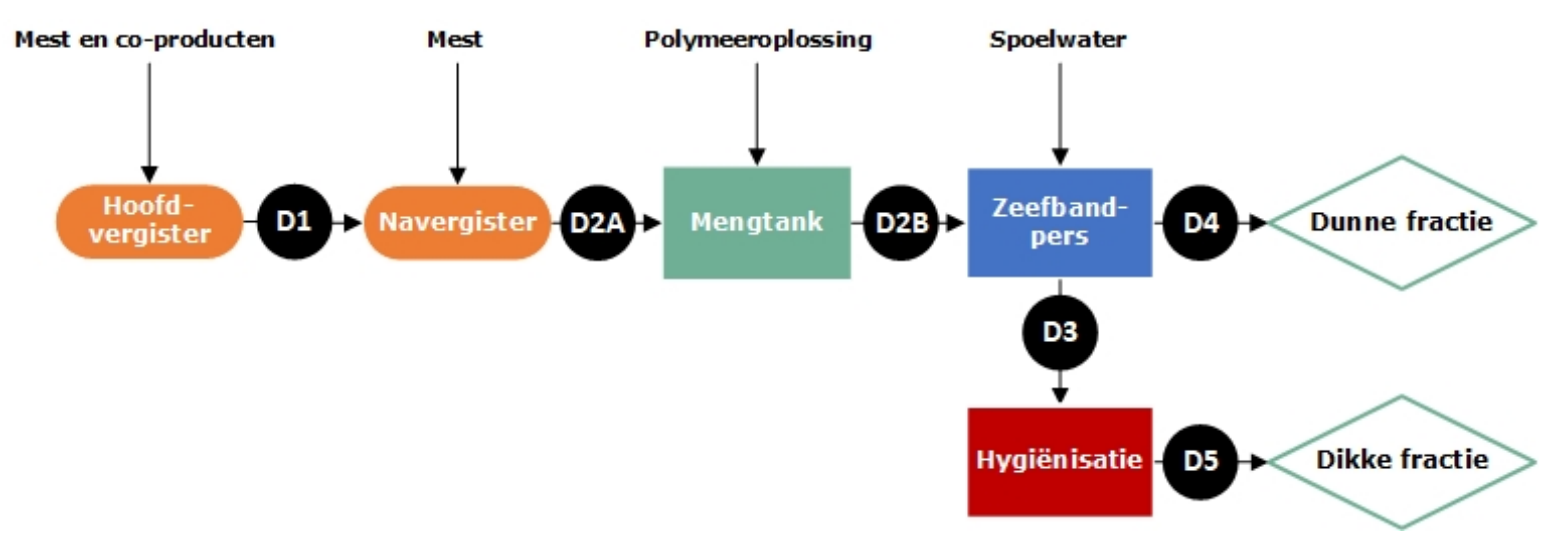

Figuur 3.6 Schematisch overzicht van de digestaatverwerkingsinstallatie van Loonbedrijf Dekker; bemonsteringspunten zijn aangegeven met een letter-nummercombinatie.

\subsubsection{Scheidingsrendementen}

Tabel 3.13 toont de samenstelling van digestaat uit de navergister en de dunne fractie en dikke fractie ervan na scheiding met de zeefbandpers. Het digestaat uit de navergister heeft een drogestofgehalte van $70 \mathrm{~g} / \mathrm{kg}$. Na scheiding ontstaat een dunne fractie met een drogestofgehalte van $18 \mathrm{~g} / \mathrm{kg}$ en een dikke fractie met een drogestofgehalte van $274 \mathrm{~g} / \mathrm{kg}$. Gemiddeld wordt $86 \%$ van het fosfaat en nagenoeg alle calcium en ijzer afgevangen in de dikke fractie. Stikstof en $\mathrm{N}^{-\mathrm{NH}_{4}}$ gaan voor respectievelijk $61 \%$ en $62 \%$ naar de dunne fractie. Naast ammonium is ook kalium goed wateroplosbaar en kalium wordt daarom ook grotendeels teruggevonden in de dunne fractie. Toch is het gehalte aan kalium en $\mathrm{N}-\mathrm{NH}_{4}$ in de dikke fractie hoger dan in de dunne fractie en dit is te verklaren door binding van deze elementen aan organische stof. De $\mathrm{N}-\mathrm{NH}_{4} / \mathrm{N}$-ratio in de dunne fractie bedraagt $82 \%$ en is daarmee ongeveer gelijk aan de ratio in het digestaat ( $80 \%)$.

Tabel 3.13 Samenstelling van de in- en uitgaande stromen van de zeefbandpers van Loonbedrijf Dekker en het berekende scheidingsrendement als percentage van het ingaande digestaat, voor de som tussen haakjes de standaardafwijking. Gemiddelde van twee bemonsteringen. ${ }^{1}$

\begin{tabular}{|c|c|c|c|c|c|c|c|c|c|}
\hline \multirow{3}{*}{ Parameter } & \multicolumn{5}{|c|}{ Samenstelling } & \multicolumn{3}{|c|}{ Scheidingsrendement ${ }^{7}$} & \multirow{3}{*}{ SOM } \\
\hline & Eenheid & Digestaat $^{2}$ & Chemie $^{3}$ & Dunne & Dikke & Eenheid $^{6}$ & Dunne & Dikke & \\
\hline & & & & fractie $^{4}$ & fractie $^{5}$ & & fractie & fractie & \\
\hline Massa & $(\mathrm{kg})$ & 1000 & 51 & 833 & 218 & $\%$ & 79 & 21 & $100( \pm 0,0)$ \\
\hline DS & $(\mathrm{g} / \mathrm{kg})$ & 70 & & 18 & 274 & $\%$ & 21 & 81 & $102( \pm 1,6)$ \\
\hline os & $(\mathrm{g} / \mathrm{kg})$ & 52 & & 10 & 216 & $\%$ & 17 & 87 & $103( \pm 2,7)$ \\
\hline $\mathrm{P}_{2} \mathrm{O}_{5}$ & $(\mathrm{~g} / \mathrm{kg})$ & 3,2 & & 0,57 & 13 & $\%$ & 15 & 86 & $101( \pm 7,2)$ \\
\hline $\mathrm{N}$ & $(\mathrm{g} / \mathrm{kg})$ & 5,2 & & 3,8 & 13 & $\%$ & 61 & 50 & $111( \pm 13)$ \\
\hline $\mathrm{N}-\mathrm{NH}_{4}$ & $(\mathrm{~g} / \mathrm{kg})$ & 4,2 & & 3,1 & 4,8 & $\%$ & 62 & 24 & $85( \pm 5,0)$ \\
\hline $\mathrm{S}$ & $(\mathrm{g} / \mathrm{kg})$ & 0,58 & & 0,18 & 2,0 & $\%$ & 25 & 73 & $98( \pm 4,2)$ \\
\hline $\mathrm{K}$ & $(\mathrm{g} / \mathrm{kg})$ & 3,1 & & 2,8 & 3,2 & $\%$ & 76 & 22 & $97( \pm 11)$ \\
\hline $\mathrm{Ca}$ & $(\mathrm{g} / \mathrm{kg})$ & 1,5 & & 0,13 & 9,7 & $\%$ & 6,9 & 135 & $141( \pm 18)$ \\
\hline $\mathrm{Mg}$ & $(\mathrm{g} / \mathrm{kg})$ & 0,69 & & 0,13 & 3,7 & $\%$ & 16 & 115 & $131( \pm 19)$ \\
\hline $\mathrm{Fe}$ & (g/kg) & 0,16 & & 0,011 & 0,83 & $\%$ & 6,5 & 118 & $124( \pm 13)$ \\
\hline $\mathrm{pH}$ & $(-)$ & 8,1 & & 8,2 & 8,7 & & & & \\
\hline \multicolumn{10}{|c|}{$\begin{array}{l}\text { Massa: totale massa van processtroom per ton verwerkt digestaat uit de navergister, DS: droge stof, OS: organische stof, n.g.: niet } \\
\text { geanalyseerd. }\end{array}$} \\
\hline \multicolumn{10}{|c|}{2 Digestaat van de navergister voor toevoeging polymeeroplossing (bemonsteringspunt D2A). } \\
\hline \multicolumn{10}{|c|}{3 Chemie: totale toegevoegde massa aan polymeeroplossing en spoelwater. } \\
\hline \multicolumn{10}{|c|}{4 Dunne fractie van de zeefbandpers na toevoeging van polymeeroplossing en spoelwater (bemonsteringspunt D4). } \\
\hline \multicolumn{10}{|c|}{5 Dikke fractie van de zeefbandpers voor hygiënisatie (bemonsteringspunt D3). } \\
\hline \multicolumn{10}{|c|}{6 Percentage t.o.v. de ingaande massa (inclusief toegevoegde chemie en bijbehorend oploswater). } \\
\hline \multicolumn{10}{|c|}{ Toevoeging van polymeeroplossing (10 liter ( $11 \mathrm{~kg}$ ) per $\mathrm{m}^{3}$ ingaand digestaat) en spoelwater (geschat op $40 \mathrm{~kg}$ per $\mathrm{m}^{3}$ ingaand digestaat) zijn } \\
\hline
\end{tabular}


De som van de berekende scheidingsrendementen naar de dunne fractie en dikke fractie is een maat voor de nauwkeurigheid van de opgestelde massabalans. De massa van de dunne en dikke fractie is groter dan die van het ingaande digestaat vanwege de toevoeging van spoelwater op de zeefbandpers en polymeeroplossing. De som van de dunne en dikke fractie ten opzichte van de ingaande stromen wijkt voor stikstof, $\mathrm{N}-\mathrm{NH}_{4}$, calcium, magnesium en ijzer meer dan $10 \%$ af van $100 \%$. Dit geeft aan dat de massabalans een grote onzekerheid kent ondanks de nauwkeurig uitgevoerde bemonstering op twee verschillende dagen. Mogelijk komt deze afwijking voor calcium, magnesium en ijzer doordat deze stoffen in de toegevoegde polymeer zitten omdat het een kationische polyacrylamide is, maar de samenstelling ervan onbekend is. Voor $\mathrm{N}-\mathrm{NH}_{4}$ is de som van de scheidingsrendementen slechts $85 \%$. Dit kan echter niet geïnterpreteerd worden als een verlies door ammoniakemissies, omdat er op basis van totaalstikstof juist een toename wordt geconstateerd. Een massabalansbenadering kan daarom niet gebruikt worden om bijvoorbeeld verliezen door gasvormige emissies te bepalen vanwege de grove kwantificering. De samenstelling van de dikke fractie voor en na hygiënisatie is vergelijkbaar voor alle gemeten componenten.

\subsubsection{Massabalans}

Omdat de mestverwerkingsinstallatie van Dekker ten tijde van de bemonsteringen slechts uit één verwerkingsstap bestond (zeefbandpers), bestaat de massabalans uit de in Tabel 3.13 getoonde scheidingsrendementen, vermenigvuldigd met de opgetelde samenstellingen van digestaat plus chemie. Deze massabalans is schematisch weergegeven in Figuur 3.7. Gebaseerd op $1000 \mathrm{~kg}$ ingaand digestaat resulteert dit in $218 \mathrm{~kg}$ gehygiëniseerde dikke fractie en $833 \mathrm{~kg}$ dunne fractie. De toegevoegde polymeeroplossing is met $11 \mathrm{~kg}$ relatief klein op massabasis. Er zijn geen verschillen in de samenstelling (droge stof, $\mathrm{N}, \mathrm{P}_{2} \mathrm{O}_{5}$ en $\mathrm{K}$ ) van de dikke fractie voor en na hygiënisatie. Gemiddeld gezien was het totaal stikstofgehalte $3 \%$ lager na hygiënisatie, maar dit verschil is te klein om te spreken van een significant verschil.

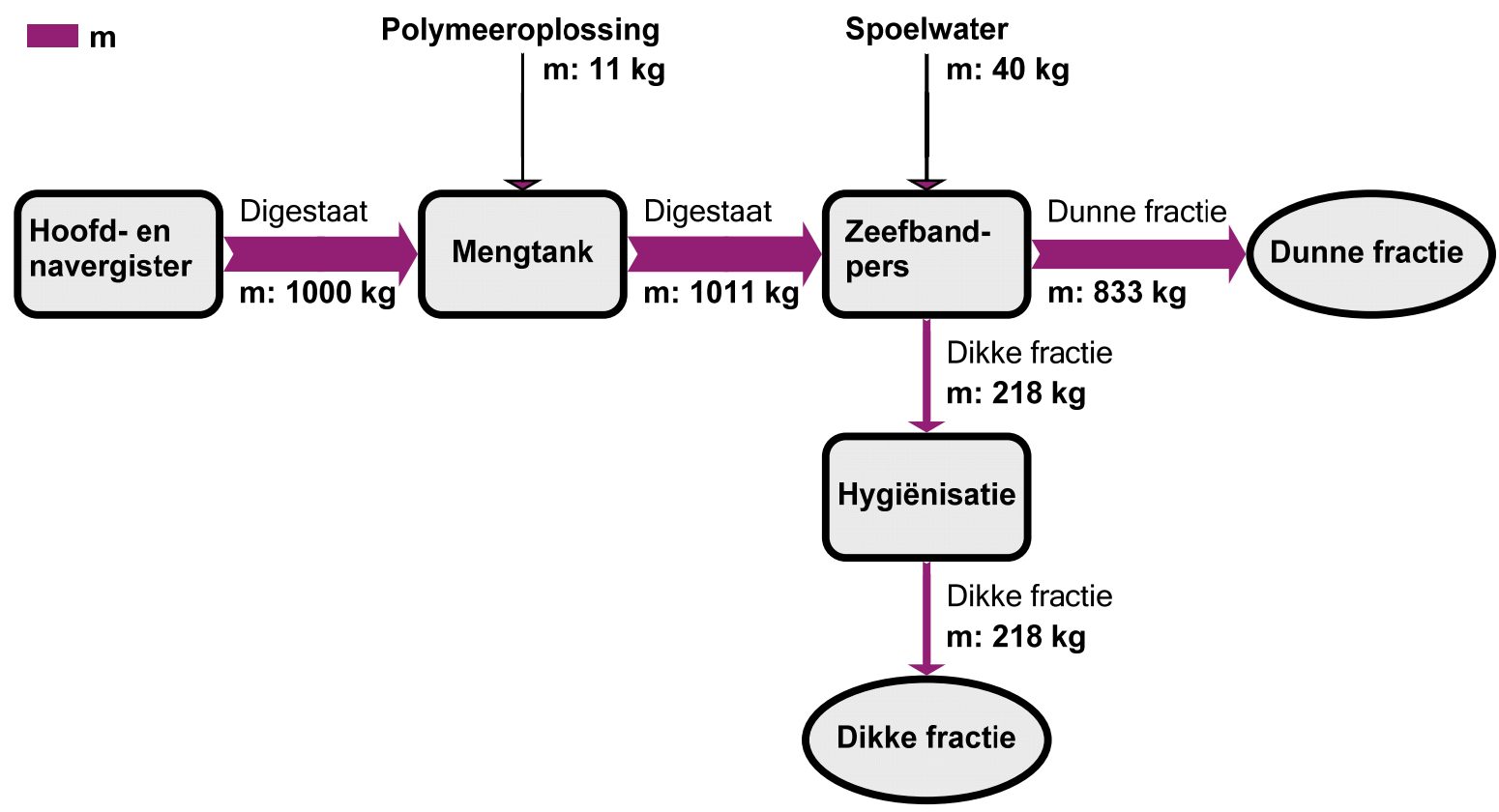

Figuur 3.7 Sankey-diagram van de totale massa $(\mathrm{m})$ per $1000 \mathrm{~kg}$ verwerkt digestaat van de digestaatverwerkingsinstallatie van Loonbedrijf Dekker.

Figuur 3.8 toont de verdeling van stikstof, fosfaat en kalium over de tussen- en eindproducten. Daarin komt ook de onnauwkeurigheid van dit soort bemonsteringen naar boven. Theoretisch zou het digestaat na de mengtank dezelfde concentraties moeten hebben als voor de mengtank, aangezien de hoeveelheid toegevoegde polymeeroplossing geen invloed heeft op de concentraties stikstof, fosfaat en kalium vanwege het verwaarloosbare volume. Toch zijn er verschillen in samenstelling voor en na de mengtank. Voor fosfaat bijvoorbeeld, is het gehalte $8 \%$ lager na de mengtank dan ervoor. De 
gerapporteerde verschillen tussen die twee stromen komen mogelijk door in-homogeniteit of door variatie in de tijd (bemonstering is een momentopname) en eventueel door de kleine foutmarge op de chemische analyses.

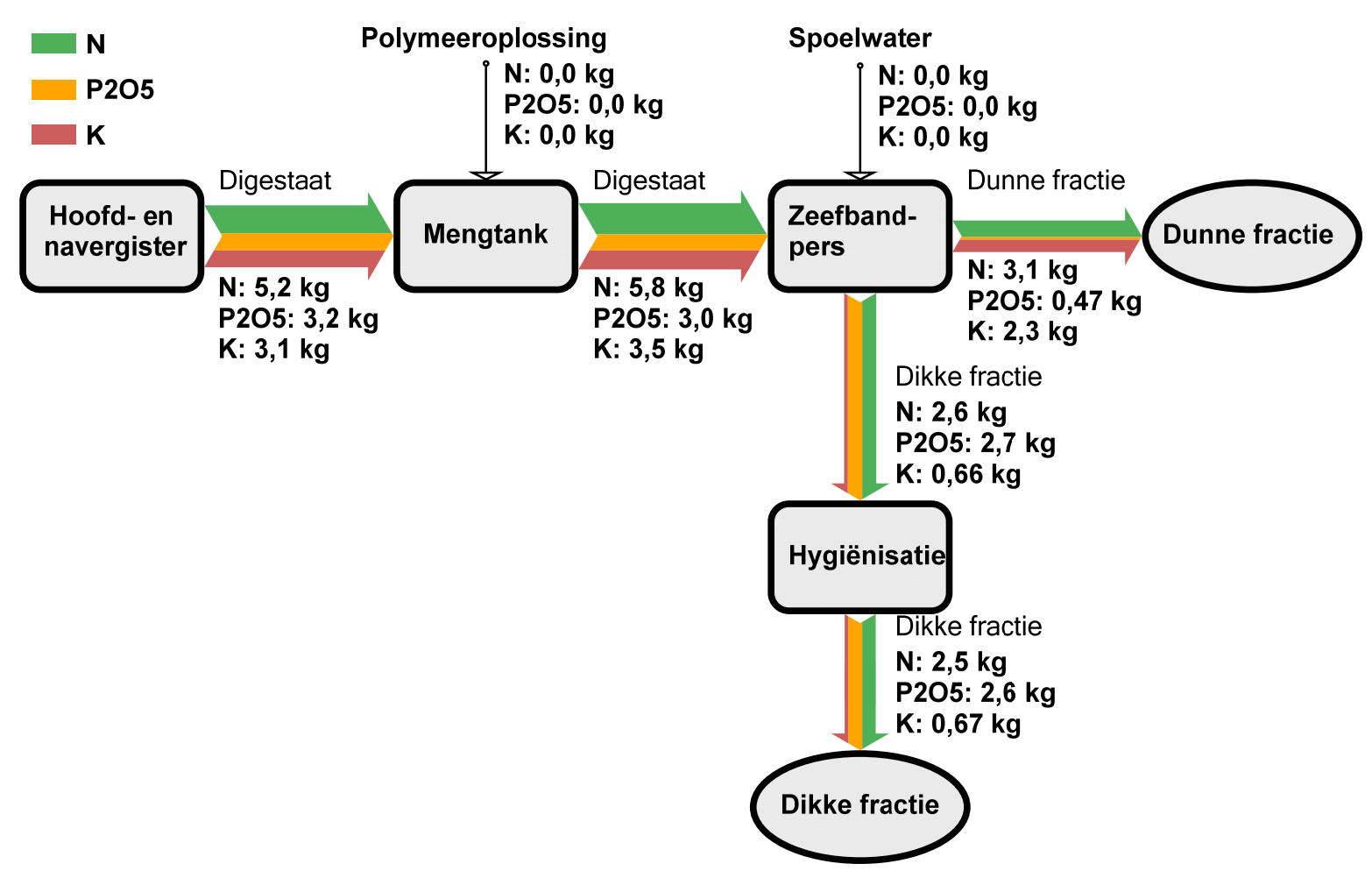

Figuur 3.8 Sankey-diagram van de massa totaalstikstof $(N)$, totaalfosfaat $\left(P_{2} O_{5}\right)$ en totaalkalium (K) per $1000 \mathrm{~kg}$ verwerkt digestaat van de digestaatverwerkingsinstallatie van Loonbedrijf Dekker; op basis van berekende debieten, vermenigvuldigd met gemeten concentraties zonder uitbalancering, daarom is de som van uitgaande stromen niet precies gelijk aan de som van ingaande stromen.

\subsubsection{Chemie- en energieverbruik}

Op de zeefbandpers wordt als flocculant circa 95 gram polymeer (een kationische polyacrylamide) toegediend per ton verwerkt digestaat. De hoeveelheid gebruikt water om deze polymeer in op te lossen, is volgens opgave van Dekker circa $10 \mathrm{~kg}$ per ton verwerkt digestaat. Het voor de zeefbandpers gebruikte spoelwater is geschat op circa $40 \mathrm{~kg}$ per ton verwerkt digestaat. In het verleden voegde Dekker als coagulant ijzersulfaat toe, tegenwoordig wordt de gewenste scheiding behaald zonder gebruik van ijzerzouten. Dit heeft als voordeel dat de dikke fractie een laag ijzergehalte heeft en het fosfaat in de dikke fractie daardoor makkelijk voor gewassen opneembaar blijft.

De jaarlijkse biogasproductie bedraagt circa 3,1 miljoen $\mathrm{m}^{3}$ (55 vol.- $\% \mathrm{CH}_{4}$ ), waarvan circa $55 \%$ afkomstig is uit dierlijke mest, inclusief ongeboren mest (gemiddeld $23 \mathrm{~m}^{3}$ biogas per ton mest met 55 vol. $-\% \mathrm{CH}_{4}$ ), en circa $45 \%$ afkomstig is uit diverse co-producten (reststromen van levensmiddelen). Biogas wordt door biogasmotoren omgezet in 6,6 GWh elektriciteit en restwarmte. Circa $12 \%$ van de opgewekte elektriciteit wordt intern verbruikt (vergister en scheiding) en het overige wordt geleverd aan het net. Restwarmte van de biogasmotor wordt gebruikt voor verwarming van de vergisters, hygiënisatie van de dikke fractie en voor verwarming van bedrijfsgebouwen. Ook wordt een deel als warm water afgezet naar een nabijgelegen bedrijf. 


\subsection{Maatschap Van Amstel}

\subsubsection{Algemene beschrijving}

Maatschap Van Amstel (Van Amstel) is gelegen in de provincie Noord-Brabant (Lith) en verwerkt circa 30.000-35.000 ton varkensdrijfmest per jaar. Uit 35.000 ton varkensdrijfmest en circa 2.657 ton chemie wordt circa 8.500 ton mestkoek (dikke fractie), 13.157 ton NK-concentraat en 16.000 ton loosbaar water geproduceerd volgens opgave van Van Amstel. Van Amstel draait mee in de pilot Mineralenconcentraat in het kader van het $6^{\mathrm{e}}$ Actieprogramma Nitraatrichtlijn. Van Amstel produceert sinds 2017 NK-concentraat waaraan voorafgaand aan de bemesting een ammoniumsulfaatoplossing wordt toegevoegd om de verhouding stikstof/kalium te vergroten. Ook wordt een nitrificatieremmer toegevoegd, zodat de kans op nitraatuitspoeling vermindert. Het geblende product wordt voornamelijk op graslandpercelen (grotendeels kleigronden en deels zandgronden) in de nabije regio $(<10 \mathrm{~km})$ afgezet. Omdat het NK-concentraat op grasland wordt toegepast, heeft Van Amstel behoefte aan een mineralenconcentraat met een lagere kalium-stikstofverhouding dan op dit moment wordt gerealiseerd. Dit omdat de kalium in het NK-concentraat vanuit bemestingsoogpunt limiterend is voor aanwending op grasland vanwege richtlijnen ter vermijding van kopziekte bij runderen. Ook wil Van Amstel geen al te hoog stikstofgehalte in het NK-concentraat om verbranding van het gras na toediening ervan te voorkomen. De mestkoek wordt afgezet naar een mesthandelaar en -exporteur, waar de dikke fractie door middel van stoom wordt gehygiëniseerd en daarna geëxporteerd wordt naar Noord-Frankijk.

\subsubsection{Technische procesbeschrijving}

De varkensdrijfmest wordt opgeslagen in een silo van $300 \mathrm{~m}^{3}$ van waaruit het naar een mengtank wordt gepompt. Daarna scheidt een zeefbandpers het in een dikke en dunne fractie. Voorafgaand wordt er in twee buffertanks respectievelijk een ijzersulfaatoplossing ( $\left.40 \% \mathrm{Fe}_{2}\left(\mathrm{SO}_{4}\right)_{3}\right)$ en polymeeroplossing (kationische polyacrylamide) toegediend. De zeefbandpers wordt continu gespoeld met een klein deel van zijn eigen dunne fractie. De afgescheiden dunne fractie van de zeefbandpers gaat over een DAF, waaraan voorafgaand dezelfde ijzersulfaat- en polymeeroplossing worden toegediend. De drijvende vaste deeltjes worden door schrapers afgescheiden en teruggeleid naar de zeefbandpers. De dunne fractie van de DAF gaat vervolgens over twee in serie geschakelde papierfilters en daarna naar de RO. Vlak voor de RO wordt zwavelzuur toegevoegd, zodat het merendeel van de ammoniak wordt omgezet naar ammonium. Het geladen ammonium wordt wel tegengehouden door de membranen, terwijl het ongeladen ammoniak dat niet wordt. Van Amstel heeft bewust niet gekozen voor twee, in serie geschakelde, RO's om het N-gehalte van het NKconcentraat niet te hoog te maken om het risico op zoutschade bij aanwending te beheersen. Het geproduceerde NK-concentraat wordt tijdens de uitrijdperiode op het eigen bedrijf opgeslagen en buiten de uitrijdperiode bij bedrijven in de regio. Het permeaat van de RO wordt over een IO geleid, waarna het via twee in elkaar overlopende buitenvijvers, voor passieve beluchting, op het oppervlaktewater wordt geloosd. Figuur 3.9 geeft het processtroomdiagram van de mestverwerkingsinstallatie van Van Amstel. 


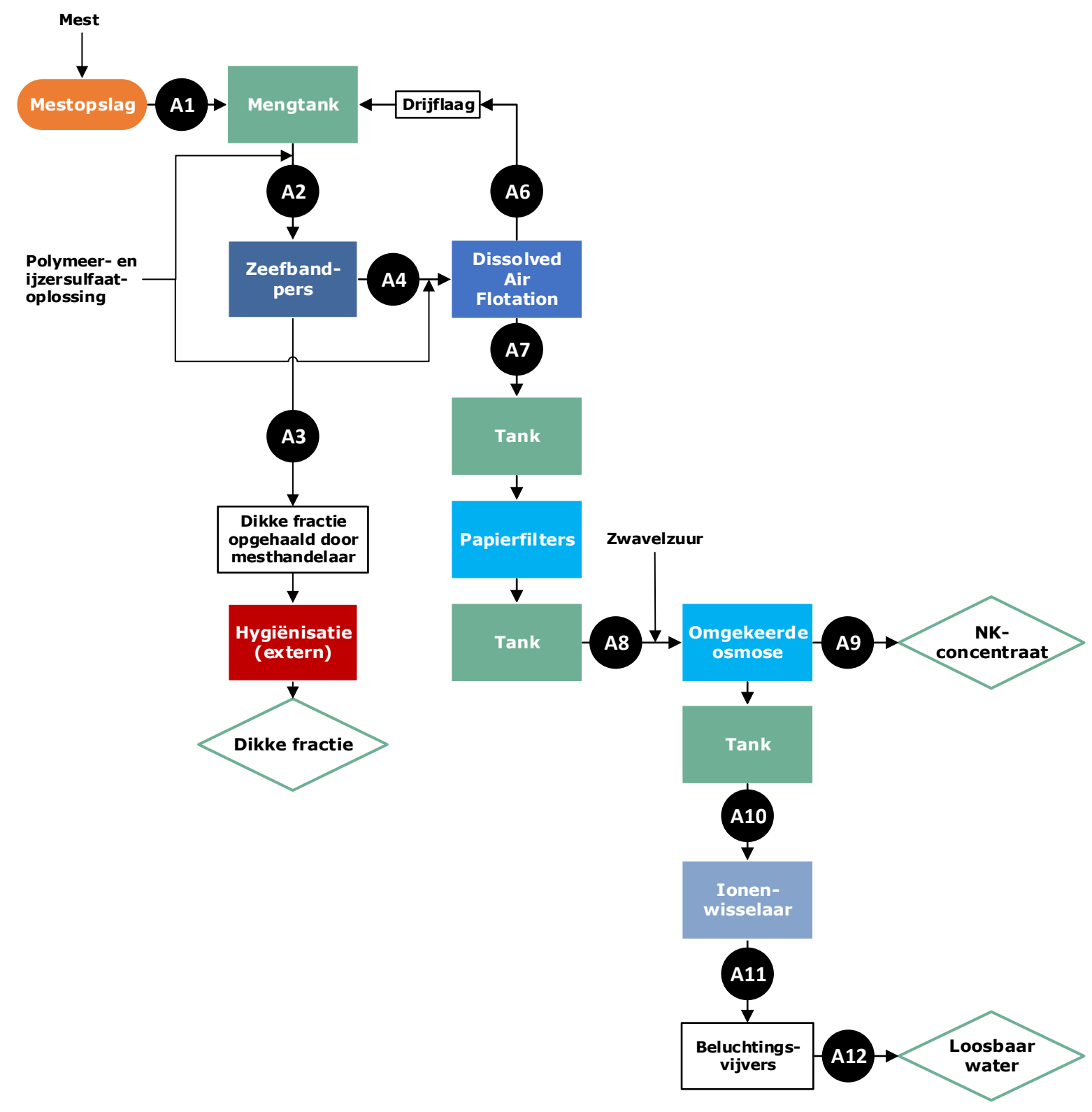

Figuur 3.9 Processtroomdiagram van de mestverwerkingsinstallatie van Van Amstel; bemonsteringspunten zijn aangegeven met een letter-nummercombinatie.

\subsubsection{Scheidingsrendementen}

\subsubsection{Zeefbandpers}

Tabel 3.14 toont de samenstelling van de in-en uitgaande stromen en de berekende scheidingsrendementen van de zeefbandpers van Van Amstel. Circa 82\% van de organische stof en $90 \%$ van het fosfaat worden afgevangen naar de dikke fractie. Kalium en ammonium gaan voor respectievelijk 85 en 74\% naar de dunne fractie. De som van de scheidingsrendementen naar de dunne en dikke fractie ligt voor alle componenten rond de $100 \%$ en wijkt alleen voor stikstof meer dan $10 \%$ af. De massabalans is opgesteld per $1000 \mathrm{~kg}$ ingaande mest in de mengtank. Daar wordt $95 \mathrm{~kg}$ polymeeroplossing, 5,6 kg Fe $2\left(\mathrm{SO}_{4}\right)_{3}$-oplossing en circa $74 \mathrm{~kg}$ retourslib van de DAF toegevoegd. De som van de massa's dunne fractie $(1002 \mathrm{~kg})$ en dikke fractie $(179 \mathrm{~kg})$ is groter dan $1000 \mathrm{~kg}$. 
Tabel 3.14 Samenstelling van de in- en uitgaande stromen van de zeefbandpers van Maatschap Van Amstel en het berekende scheidingsrendement als percentage van de ingaande mest; voor de som tussen haakjes de standaardafwijking. Gemiddelde van drie bemonsteringen. ${ }^{1}$

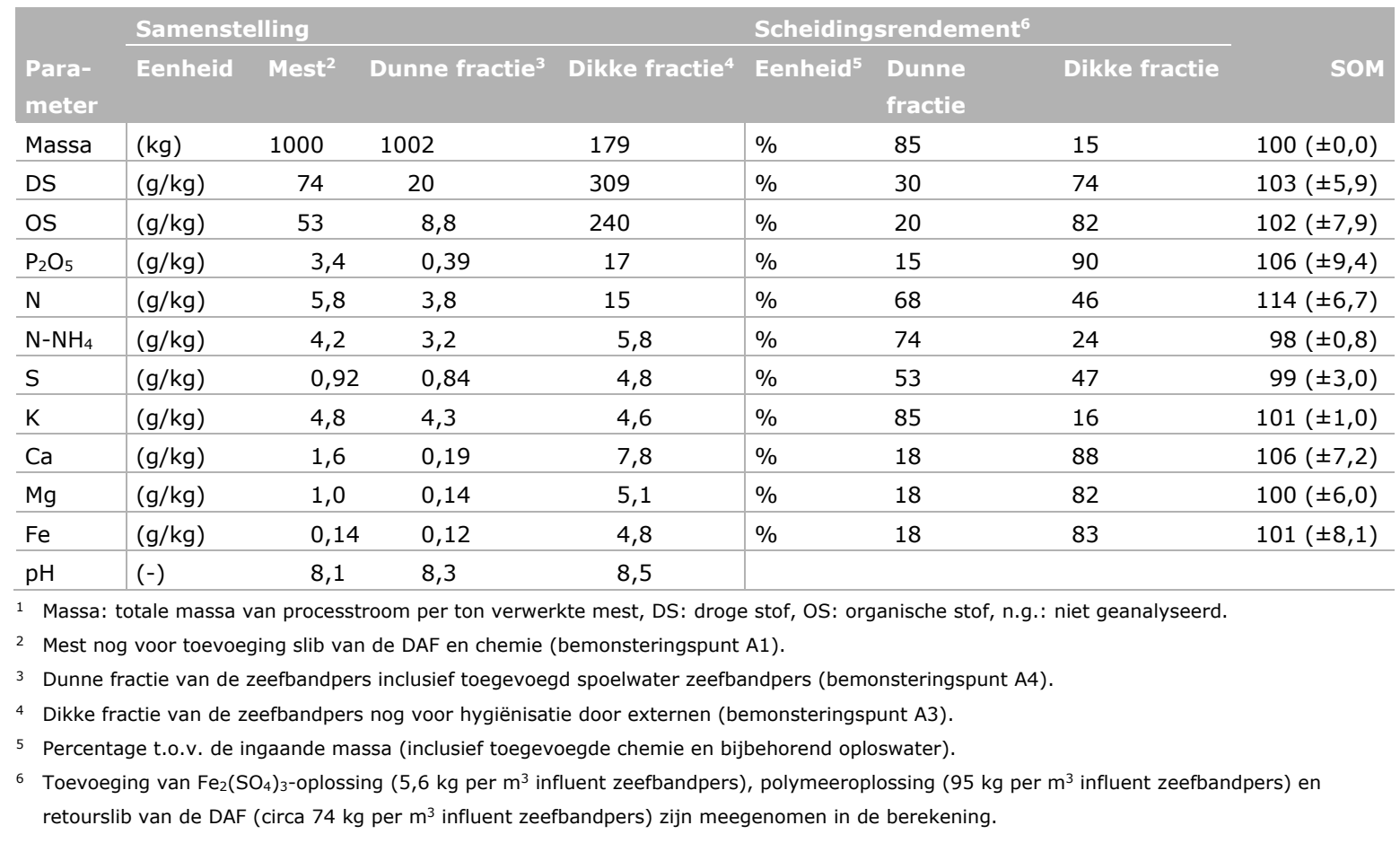

\subsubsection{Dissolved Air Flotation-installatie}

De DAF heeft als doel om een deel van de nog overgebleven deeltjes, organisch stikstof en fosfaat uit de dunne fractie te verwijderen. Tabel 3.15 toont de gemiddelde samenstelling van de in- en uitgaande stromen en de berekende scheidingsrendementen van de DAF.

Fosfaat, calcium en ijzer worden voor circa 70\% afgevangen in slib van de DAF en deze hoge mate van fosfaatverwijdering is te relateren aan de toevoeging van ijzersulfaatoplossing voor de DAF. Na de DAF resteert een dunne fractie met een $\mathrm{P}_{2} \mathrm{O}_{5}$ concentratie van $<150 \mathrm{mg} / \mathrm{L}$ en een drogestofgehalte van $17 \mathrm{~g} / \mathrm{kg}$. Organische stof wordt minder effectief verwijderd: slechts $24 \%$ van de ingaande organische stof wordt afgevangen. Verwijdering van organische stof is relevant, omdat daarmee ook organisch stikstof verwijderd wordt, wat nodig is om te voldoen aan de criteria voor kunstmestvervangers ( $\mathrm{N}$ $\mathrm{NH}_{4} / \mathrm{N}>90 \%$ ). Het effluent van de DAF voldoet nu net niet aan dit criterium. Daarnaast is verwijdering van organische stof van belang om dichtslibben van de membranen van de RO te voorkomen. De DAF produceert een waterig slib met een drogestofgehalte van $27 \mathrm{~g} / \mathrm{kg}$. De som van de massaeffluent (951 kg) en slib $(74 \mathrm{~kg}$ ) is groter dan de massa van het influent (1002 kg) door de toevoeging van $1,5 \mathrm{~kg} \mathrm{40 \%} \mathrm{Fe}_{2}\left(\mathrm{SO}_{4}\right)_{3}$-oplossing en $21 \mathrm{~kg}$ polymeeroplossing per ton influent van de zeefbandpers. 
Tabel 3.15 Samenstelling van de in- en uitgaande stromen van de DAF van Maatschap Van Amstel en het berekende scheidingsrendement als percentage van het influent; voor de som tussen haakjes de standaardafwijking. Gemiddelde van drie bemonsteringen. ${ }^{1}$

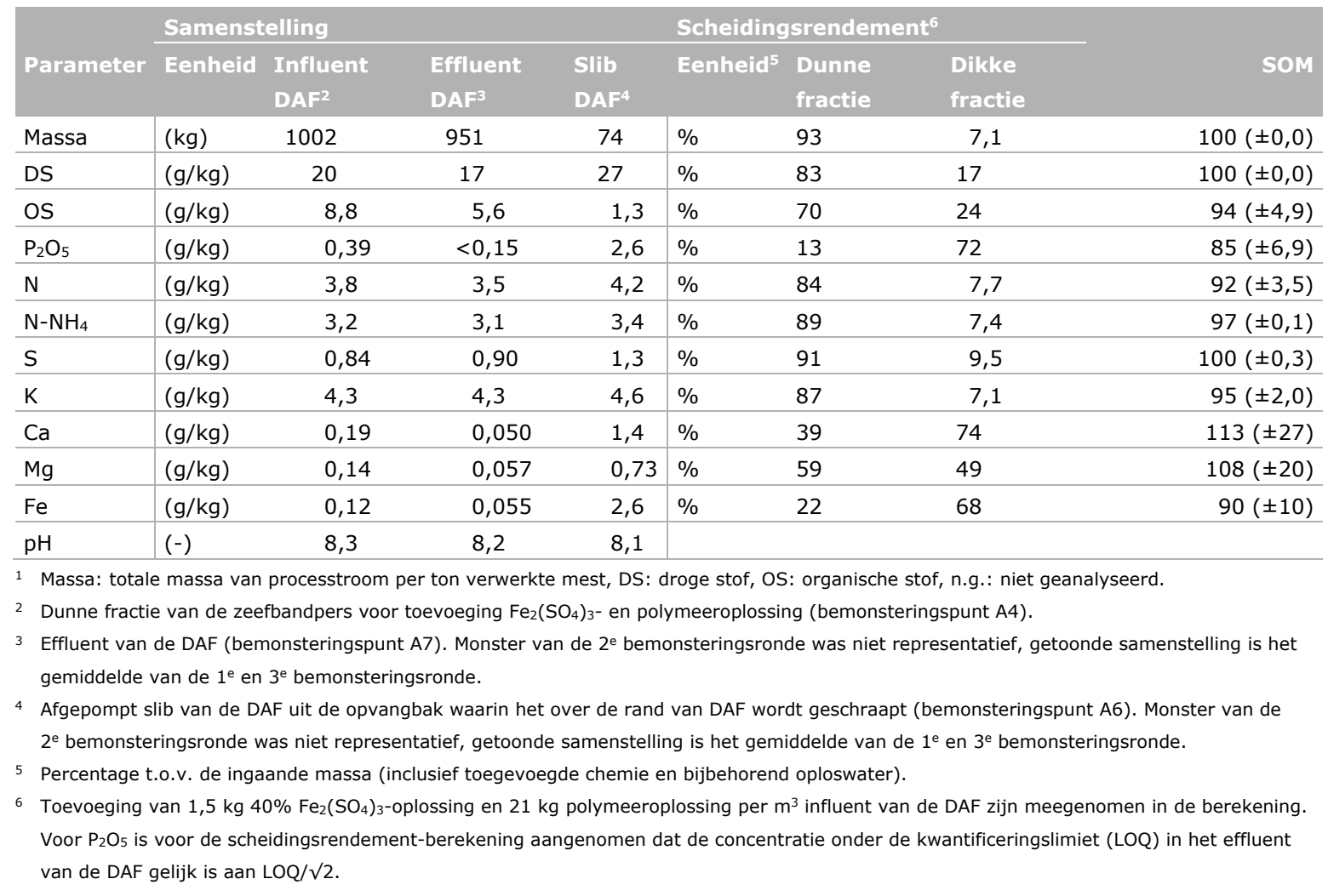

\subsubsection{Papierfilters}

Het effluent van de DAF stroomt door twee in serie geschakelde papierfilters. Dit is een laatste vangnet voor de RO om deeltjes die nog in de vloeistof zijn achtergebleven, eruit te halen.

Tabel 3.16 toont de samenstelling van de in- en uitgaande stromen van de papierfilters. Voor sommige componenten is de gemiddelde concentratie in het effluent lager dan in het influent, terwijl het voor andere componenten juist hoger is in het effluent. De verschillen zijn dusdanig klein dat niet van een concentratieverschil gesproken kan worden. Daarom zijn geen scheidingsrendementen berekend.

Het reinigingswater van de RO wordt periodiek teruggevoerd naar het influent van het tweede papierfilter. Dat influent is dan helder van kleur in plaats van bruin en troebel zoals normaal. Ook het spuiwater (concentraat) van de tweede en derde 'stage' van de RO gaat retour naar de papierfilters. Dit gebeurt niet continu, maar alleen wanneer de tweede en derde 'stage' van de RO in bedrijf zijn. Dit gezamenlijk geeft extra temporele variatie in de samenstelling van het influent en effluent van de

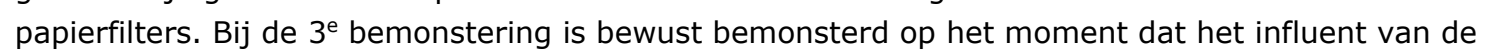
papierfilters de normale bruine kleur had en troebel was. 
Tabel 3.16 Samenstelling van het influent en effluent van de papierfilters van Maatschap Van Amstel. Gemiddelde van drie bemonsteringen. ${ }^{1}$

\begin{tabular}{|c|c|c|c|}
\hline \multirow[b]{2}{*}{ Parameter } & \multicolumn{3}{|c|}{ Samenstelling } \\
\hline & Eenheid & Influent papierfilters ${ }^{2}$ & Effluent papierffilters ${ }^{3}$ \\
\hline Massa & $(\mathrm{kg})$ & 951 & 951 \\
\hline OS & $(\mathrm{g} / \mathrm{kg})$ & 5,6 & 5,5 \\
\hline $\mathrm{P}_{2} \mathrm{O}_{5}$ & $(\mathrm{~g} / \mathrm{kg})$ & $<0,15$ & $<0,15$ \\
\hline $\mathrm{N}-\mathrm{NH}_{4}$ & $(\mathrm{~g} / \mathrm{kg})$ & 3,1 & 3,0 \\
\hline $\mathrm{S}$ & $(\mathrm{g} / \mathrm{kg})$ & 0,90 & 1,1 \\
\hline $\mathrm{K}$ & $(\mathrm{g} / \mathrm{kg})$ & 4,3 & 4,0 \\
\hline $\mathrm{Ca}$ & $(\mathrm{g} / \mathrm{kg})$ & 0,050 & 0,060 \\
\hline \multicolumn{4}{|c|}{1 Massa: totale massa van processtroom per ton verwerkte mest, DS: droge stof, OS: organische stof, n.g.: niet geanalyseerd. } \\
\hline \multicolumn{4}{|c|}{$\begin{array}{l}2 \text { Effluent van de DAF (bemonsteringspunt A7). Monster van de } 2^{\mathrm{e}} \text { bemonsteringsronde was niet representatief, getoonde samenstelling is het } \\
\text { gemiddelde van de } 1^{\mathrm{e}} \text { en } 3^{\mathrm{e}} \text { bemonsteringsronde. }\end{array}$} \\
\hline
\end{tabular}

\subsubsection{Omgekeerde osmose-installatie}

Alle componenten in het influent van de RO eindigen voor praktisch gezien $100 \%$ in het NKconcentraat. Tabel 3.17 toont daarom de samenstelling van de in- en uitgaande stromen van de RO en de berekende concentratiefactor i.p.v. de scheidingsrendementen. Per ton ingaande mest verwerkt de RO $951 \mathrm{~kg}$ influent tot $546 \mathrm{~kg} \mathrm{NK}$-concentraat en $406 \mathrm{~kg}$ permeaat. De concentratiefactoren liggen voor alle componenten dicht bij elkaar (tussen de 1,6 en 1,8). Het influent wordt dus met circa een factor 1,7 ingedikt tot een NK-concentraat met een stikstofgehalte van gemiddeld $5,6 \mathrm{~g} / \mathrm{kg}$. Fosfaat is al verwijderd in de voorliggende stappen en het gehalte $\mathrm{P}_{2} \mathrm{O}_{5}$ van het permeaat is lager dan de kwantificeringslimiet van $0,2 \mathrm{mg} / \mathrm{kg}$. De hogere berekende concentratiefactor voor zwavel komt door het toegevoegde zwavel als zwavelzuur. Zwavelzuur wordt voor de RO toegevoegd om de retentie van $\mathrm{N}-\mathrm{NH}_{4}$ in de vorm van ammonium te verhogen. De dosering hiervan wordt niet gemeten op basis van debietmeters of pompdebieten. Van Amstel schat de dosering op circa 2-4 liter 50\% zwavelzuur per $\mathrm{m}^{3}$ influent van de RO. Op basis van de hoeveelheid zwavel in het influent van de RO, het NKconcentraat en het permeaat van de RO is de dosering berekend op circa 1,3 liter $(1,8 \mathrm{~kg}) 50 \%$ zwavelzuur per $\mathrm{m}^{3}$ influent van de RO. Dit staat gelijk aan 0,29 kg S per $\mathrm{m}^{3}$ influent van de RO. 
Tabel 3.17 Samenstelling van de in- en uitgaande stromen van de omgekeerde osmose-installatie van Maatschap Van Amstel en de berekende concentratiefactor daarvan. Gemiddelde van drie bemonsteringen. ${ }^{1}$

\begin{tabular}{|c|c|c|c|c|c|}
\hline \multirow[b]{2}{*}{ Parameter } & \multicolumn{4}{|c|}{ Samenstelling } & \multirow[t]{2}{*}{ Concentratiefactor ${ }^{5}$} \\
\hline & Eenheid & Influent ${ }^{2}$ & Concentraat ${ }^{3}$ & Permeaat ${ }^{4}$ & \\
\hline Massa & $(\mathrm{kg})$ & 951 & 546 & 407 & - \\
\hline OS & $(\mathrm{g} / \mathrm{kg})$ & 5,5 & 9,5 & n.g. & 1,8 \\
\hline $\mathrm{P}_{2} \mathrm{O}_{5}$ & $(\mathrm{~g} / \mathrm{kg})$ & $<0,15$ & 0,096 & $<0,0002$ & - \\
\hline $\mathrm{N}-\mathrm{NH}_{4}$ & $(\mathrm{~g} / \mathrm{kg})$ & 3,0 & 5,3 & 0,0074 & 1,8 \\
\hline $\mathrm{S}$ & $(\mathrm{g} / \mathrm{kg})$ & 1,1 & 2,4 & $<0,0002$ & 2,3 \\
\hline $\mathrm{K}$ & $(\mathrm{g} / \mathrm{kg})$ & 4,0 & 7,2 & 0,0017 & 1,8 \\
\hline $\mathrm{Ca}$ & $(\mathrm{g} / \mathrm{kg})$ & 0,060 & 0,10 & $<0,0012$ & 1,7 \\
\hline $\mathrm{Mg}$ & $(\mathrm{g} / \mathrm{kg})$ & 0,082 & 0,15 & $<0,00015$ & 1,8 \\
\hline
\end{tabular}

1 Massa: totale massa van processtroom per ton verwerkt digestaat uit de navergister, DS: droge stof, OS: organische stof, n.g.: niet geanalyseerd.

2 Effluent van het $2^{\mathrm{e}}$ in serie geschakelde papierfilter vóór dosering van zwavelzuur (bemonsteringspunt A8).

3 NK-concentraat (bemonsteringspunt A9).

4 Permeaat van de omgekeerde osmose-installatie (bemonsteringspunt A10).

5 Concentratie in het NK-concentraat gedeeld door de concentratie in het influent van de omgekeerde osmose-installatie.

\subsubsection{Ionenwisselaars}

De ionenwisselaars dienen als laatste zuiveringsstap om zouten te verwijderen tot concentraties onder de criteria voor lozing. Tabel 3.18 toont de gemeten concentraties in het influent en effluent van de ionenwisselaars. Het effluent bevat gemiddeld $4,3 \mathrm{mg} \mathrm{N}-\mathrm{NH}_{4}$ en $0,76 \mathrm{mg}$ kalium per liter en heeft een neutrale $\mathrm{pH}$.

Gemiddeld zijn de concentraties na de ionenwisselaars voor stikstof, $\mathrm{N}-\mathrm{NH}_{4}$ en kalium lager dan ervoor. De concentraties in het influent en effluent bij de $1^{\mathrm{e}}$ en $2^{\mathrm{e}}$ bemonstering waren praktisch gelijk aan elkaar. Alleen bij de $3^{e}$ bemonsteringsronde waren voor die componenten de concentraties duidelijk lager in het effluent dan influent. Het verwijderingspercentage is daarom niet getoond. De ionenwisselaar heeft dus de functie van een veiligheidsfilter voor de momenten waarop de RO de benodigde kwaliteit van het permeaat ervan niet behaalt. Dit verklaart ook waarom de ionenwisselaars volgens opgave van Van Amstel slechts ongeveer eens in de twee maanden geregenereerd hoeven te worden, wat grofweg neerkomt op eens per 2.000 à $3.000 \mathrm{~m}^{3}$ geloosd water.

Tabel 3.18 Samenstelling van het influent en effluent van de ionenwisselaars van Maatschap Van Amstel. Gemiddelde van drie bemonsteringen. ${ }^{1}$

\begin{tabular}{llll} 
Parameter & Eenheid & Influent ionenwisselaars & Effluent ionenwisselaars \\
Massa & $(\mathrm{kg})$ & 407 & 407 \\
\hline $\mathrm{DS}$ & $(\mathrm{g} / \mathrm{kg})$ & $\mathrm{n} . \mathrm{g}$. & $\mathrm{n} . \mathrm{g}$. \\
$\mathrm{OS}$ & $(\mathrm{g} / \mathrm{kg})$ & $\mathrm{n} . \mathrm{g}$. & $\mathrm{n} . \mathrm{g}$. \\
\hline $\mathrm{P}_{2} \mathrm{O}_{5}$ & $(\mathrm{~g} / \mathrm{kg})$ & $<0,0002$ & $<0,0002$ \\
$\mathrm{~N}$ & $(\mathrm{~g} / \mathrm{kg})$ & 0,0074 & 0,0044 \\
\hline $\mathrm{N}-\mathrm{NH}_{4}$ & $(\mathrm{~g} / \mathrm{kg})$ & 0,0074 & 0,0043 \\
\hline $\mathrm{S}$ & $(\mathrm{g} / \mathrm{kg})$ & $<0,0002$ & $<0,0001$ \\
\hline $\mathrm{K}$ & $(\mathrm{g} / \mathrm{kg})$ & 0,0017 & 0,00076 \\
$\mathrm{Ca}$ & $(\mathrm{g} / \mathrm{kg})$ & $<0,0012$ & $<0,0012$ \\
\hline $\mathrm{Mg}$ & $(\mathrm{g} / \mathrm{kg})$ & $<0,00015$ & $<0,00015$ \\
\hline $\mathrm{Fe}$ & $(\mathrm{g} / \mathrm{kg})$ & $<0,00009$ & $<0,00009$ \\
\hline $\mathrm{pH}$ & $(-)$ & 6,1 & 5,9 \\
\hline 1 & Massa: totale massa van processtroom per ton verwerkt digestaat uit de navergister, DS: droge stof, OS: organische stof, n.g.: niet geanalyseerd. \\
2 & Bemonsteringspunt A10. &
\end{tabular}




\subsubsection{Massabalans}

Een massabalans is opgesteld op basis van de gemeten samenstellingen van de genomen monsters, de daaruit berekende scheidingsrendementen en de gegevens over het chemieverbruik. De retourstroom van het slib van de DAF is door middel van iteratie berekend. Figuur 3.10 enFiguur 3.11 tonen de stroomdiagrammen voor de totale massa van de verwerkte mest en de elementen stikstof, fosfaat en kalium.

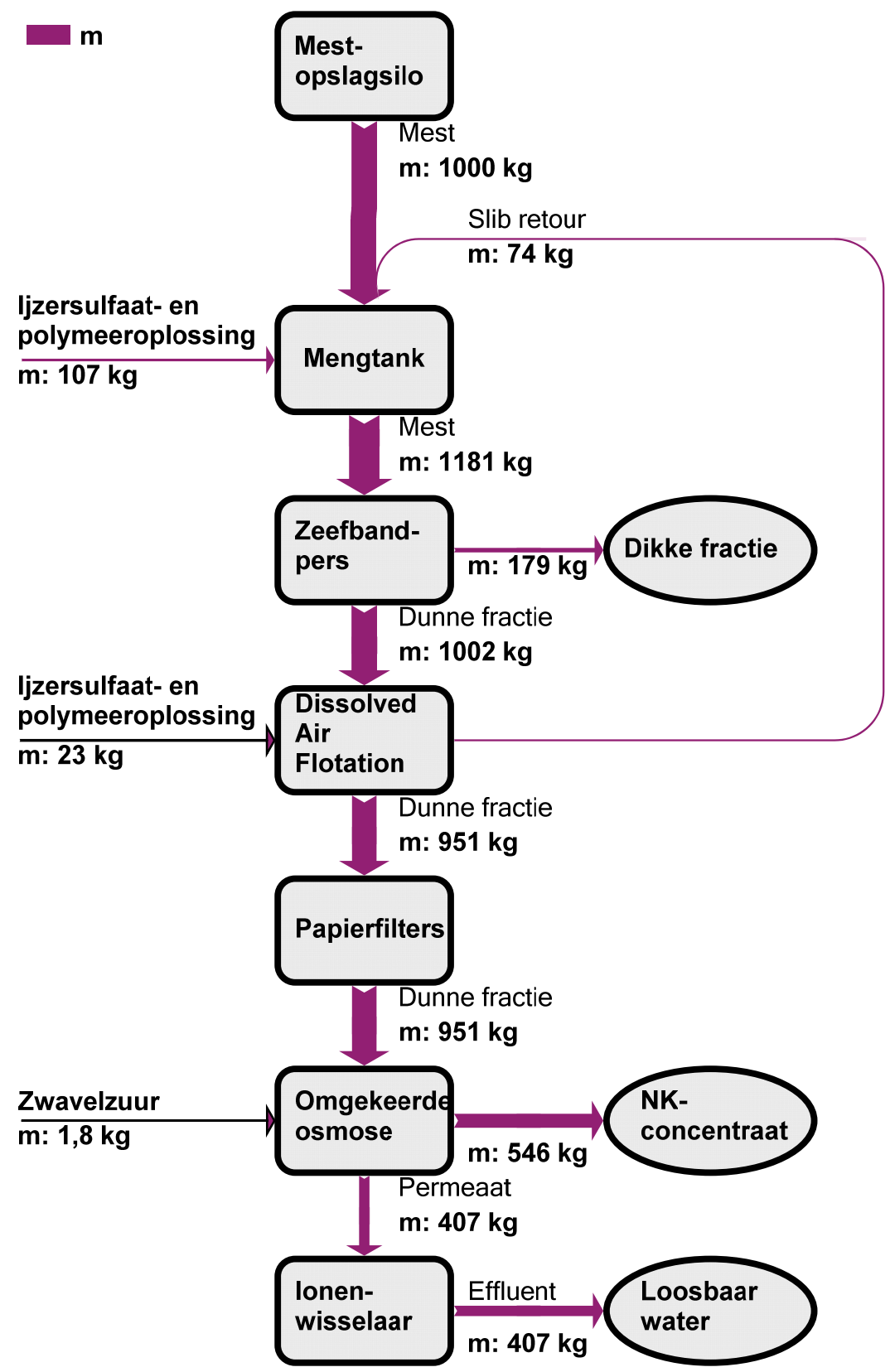

Figuur 3.10 Sankey-diagram van de totale massa $(\mathrm{m})$ per $1000 \mathrm{~kg}$ verwerkte varkensdrijfmest van de mestverwerkingsinstallatie van Maatschap Van Amstel; op basis van berekende debieten zonder uitbalancering, daarom is de som van uitgaande stromen niet precies gelijk aan de som van ingaande stromen.

De massabalans is opgesteld per $1000 \mathrm{~kg}$ ingaande varkensdrijfmest. Elke $1000 \mathrm{~kg}$ verwerkte mest resulteert in $179 \mathrm{~kg}$ dikke fractie, $546 \mathrm{~kg} \mathrm{NK}$-concentraat en $406 \mathrm{~kg}$ loosbaar water. Deze berekende getallen wijken af van de door Van Amstel opgegeven getallen in paragraaf 3.4.1. Volgens opgave van Van Amstel resulteert elke $1000 \mathrm{~kg}$ verwerkte mest in $243 \mathrm{~kg}$ dikke fractie, $376 \mathrm{~kg}$ NK-concentraat en $457 \mathrm{~kg}$ loosbaar water. Waar dit verschil aan ligt, is onduidelijk. 
De gezamenlijke berekende massa aan eindproducten uit één ton mest is $1131 \mathrm{~kg}$ door toevoeging van $132 \mathrm{~kg}$ aan chemie $\left(\mathrm{Fe}_{2}\left(\mathrm{SO}_{4}\right)_{3}\right.$, polymeer en zwavelzuur) en bijbehorend oploswater. De massa van de dikke fractie en het NK-concentraat bedraagt samen $724 \mathrm{~kg}$ per $1000 \mathrm{~kg}$ ingaande mest. De per as te transporteren massa is dus met $28 \%$ verlaagd ten opzichte van de ingaande mest.

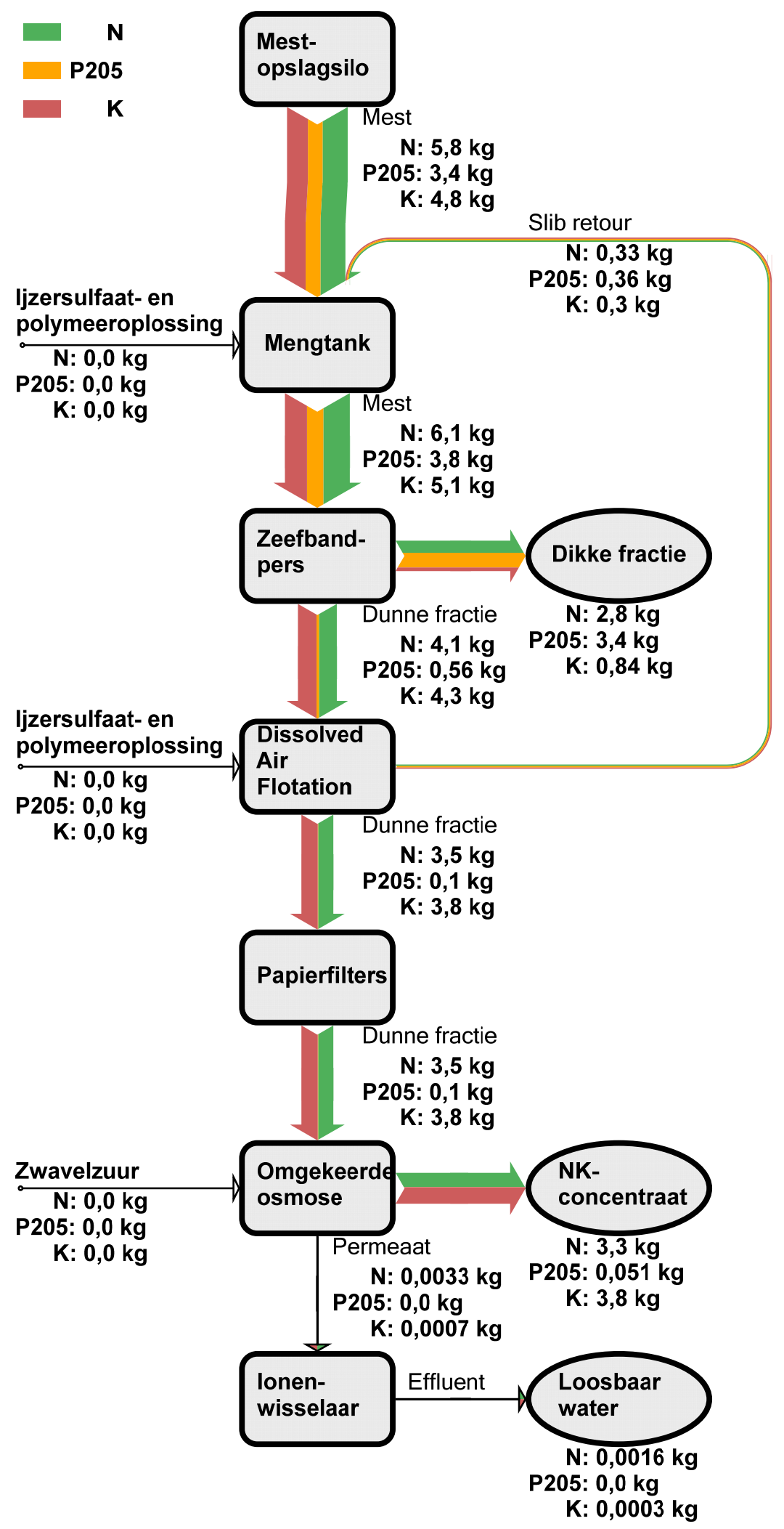

Figuur 3.11 Sankey-diagram van de massa totaalstikstof $(N)$, totaalfosfaat $\left(P_{2} \mathrm{O}_{5}\right)$ en totaalkalium (K) per $1000 \mathrm{~kg}$ verwerkte varkensdrijfmest van de mestverwerkingsinstallatie van Maatschap Van Amstel op basis van berekende debieten, vermenigvuldigd met gemeten concentraties zonder uitbalancering, daarom is de som van uitgaande stromen niet precies gelijk aan de som van ingaande stromen. 
Uit Figuur 3.11 is op te maken dat het ingaande fosfaat $(3,4 \mathrm{~kg})$ volledig in de dikke fractie van de zeefbandpers $(3,4 \mathrm{~kg})$ terechtkomt. De zeefbandpers scheidt $90 \%$ van het fosfaat af, maar door continue terugvoer van het DAF-slib - met daarin nagenoeg de overige $10 \%$ van het fosfaat, wordt over het hele systeem gezien praktisch alle fosfaat afgevoerd via de dikke fractie. Van het ingaande kalium komt circa $80 \%$ in het NK-concentraat terecht. Voor stikstof valt op dat de som aan wat er in de dikke fractie $(2,8 \mathrm{~kg})$ en dunne fractie $(4,1 \mathrm{~kg})$ van de zeefbandpers terechtkomt, zo'n 10 à $15 \%$ groter is dan wat er in het influent ervan zit $(6,1 \mathrm{~kg})$. Dit komt mogelijk door de heterogeniteit en temporele variatie in de samenstelling van de stromen, wat het nemen van een representatief monster bemoeilijkt.

Tabel 3.19 toont de berekende massabalans per $1000 \mathrm{~kg}$ verwerkte mest van de mestverwerkingsinstallatie van Van Amstel. Het totaal aan eindproducten als percentage van de ingaande mest plus chemie en bijbehorend oploswater ligt voor alle componenten in de buurt van de $100 \%$. Dat dit percentage voor $\mathrm{N}-\mathrm{NH}_{4} 93 \%$ is, wil niet zeggen dat er $7 \%$ aan ammoniakemissies zijn. Dit omdat het percentage voor totaal stikstof juist groter is dan $100 \%$.

Tabel 3.19 Massbalans van de mestverwerkingsinstallatie van Maatschap Van Amstel in $\mathrm{kg}$ per ton ingaande mest, gemiddelde van drie bemonsteringen. ${ }^{1}$

\begin{tabular}{|c|c|c|c|c|c|c|}
\hline Parameter & $\begin{array}{l}\text { Mest } \\
(\mathrm{kg})\end{array}$ & $\begin{array}{l}\text { Chemie }^{2} \\
\text { (kg) }\end{array}$ & $\begin{array}{l}\text { Dikke fractie } \\
(\mathrm{kg})\end{array}$ & $\begin{array}{l}\text { NK-concentraat } \\
(\mathbf{k g})\end{array}$ & $\begin{array}{l}\text { Loosbaar water } \\
\text { (kg) }\end{array}$ & $\begin{array}{l}\text { Totaal } \\
\text { eindproducten } \\
\\
(\%)\end{array}$ \\
\hline Massa & 1000 & 132 & 179 & 546 & 407 & 100 \\
\hline DS & 74 & & 58 & 20 & & 105 \\
\hline os & 53 & & 46 & 7,8 & & 101 \\
\hline $\mathrm{P}_{2} \mathrm{O}_{5}$ & 3,4 & & 3,4 & 0,051 & & 102 \\
\hline $\mathrm{N}$ & 5,8 & & 2,8 & 3,3 & & 105 \\
\hline $\mathrm{N}-\mathrm{NH}_{4}$ & 4,2 & & 1,1 & 2,9 & & 95 \\
\hline $\mathrm{S}$ & 0,92 & 1,0 & 0,76 & 1,1 & & 99 \\
\hline K & 4,8 & & 0,84 & 3,8 & & 96 \\
\hline $\mathrm{Ca}$ & 1,6 & & 1,6 & 0,11 & & 107 \\
\hline $\mathrm{Mg}$ & 1,0 & & 0,93 & 0,11 & & 101 \\
\hline $\mathrm{Fe}$ & 0,14 & 0,83 & 0,86 & 0,070 & & 95 \\
\hline \multicolumn{7}{|c|}{1 Massa: totale massa van processtroom per ton verwerkte mest, DS: droge stof, OS: organische stof, n.g.: niet geanalyseerd. } \\
\hline \multicolumn{7}{|c|}{2 Chemie: totale toegevoegde massa aan $\mathrm{Fe}_{2}\left(\mathrm{SO}_{4}\right)_{3}$-oplossing, polymeeroplossing en zwavelzuur. } \\
\hline \multicolumn{7}{|c|}{3 Als percentage van ingaande mest plus toegevoegde chemie en bijbehorend oploswater. } \\
\hline
\end{tabular}

\subsubsection{Chemie- en energieverbruik}

Per ton influent van de zeefbandpers werd ten tijde van de bemonsteringen circa $5,6 \mathrm{~kg} 40 \%$ $\mathrm{Fe}_{2}\left(\mathrm{SO}_{4}\right)_{3}$-oplossing $\left(1,2 \mathrm{~kg} \mathrm{Fe} 2\left(\mathrm{SO}_{4}\right)_{3}\right)$ en circa $95 \mathrm{~kg}$ polymeeroplossing, een kationische polyacrylamide toegevoegd. Vlak voor de DAF werd nog circa 1,5 kg 40\% Fe $2\left(\mathrm{SO}_{4}\right)_{3}$-oplossing $(0,4 \mathrm{~kg}$ $\left.\mathrm{Fe}_{2}\left(\mathrm{SO}_{4}\right)_{3}\right)$ en circa $21 \mathrm{~kg}$ van dezelfde polymeeroplossing toegevoegd per ton influent van de DAF.

De dosering van $50 \%$ zwavelzuur is berekend op 1,3 liter $(1,8 \mathrm{~kg})$ per $\mathrm{m}^{3}$ influent van de RO als gemiddelde van de drie bemonsteringen. Dit ligt in de buurt van het door Van Amstel geschatte verbruik van 2-4 liter per $\mathrm{m}^{3}$ influent van de RO.

Uitgedrukt per ton verwerkte mest en omgerekend naar de hoeveelheid werkzame stof in de chemievloeistoffen werd ten tijde van de bemonsteringen in totaal circa 2,6 kg droge $\mathrm{Fe}_{2}\left(\mathrm{SO}_{4}\right)_{3}$ poeder, $122 \mathrm{~kg}$ polymeeroplossing (omrekening naar droog poeder niet mogelijk) en 0,43 kg zwavel als zwavelzuur toegevoegd.

De circa 8.500 ton per jaar geproduceerde dikke fractie wordt afgezet naar een andere verwerker, $5 \mathrm{~km}$ bij Van Amstel vandaan. Dit kost Van Amstel 23-25 euro per afgezette ton. Deze verwerker hygiëniseert de dikke fractie door middel van stoom en exporteert het daarna per vrachtwagen naar Noord-Frankijk. De circa 13.157 ton per jaar geproduceerde NK-concentraat wordt allemaal in de 
nabije regio ( $<25 \mathrm{~km}$ ) afgezet, voornamelijk op graslandpercelen (grotendeels klei- en deels zandgronden). Het elektriciteitsverbruik van de mestverwerkingsinstallatie is niet bekend, omdat er op het bedrijf grote elektriciteitsverbruikers voor andere landbouwdoeleinden aanwezig zijn en alleen het totale elektriciteitsverbruik wordt gemeten.

\subsection{Merensteyn}

\subsubsection{Algemene beschrijving}

De mestverwerkingsinstallatie van Merensteyn, onderdeel van Mestac, ligt in Noord-Limburg (Ysselsteyn) en verwerkt varkensdrijfmest van ruim 80 varkensbedrijven die veelal zijn gelegen in Zuidoost-Nederland. Merensteyn verwerkte in 2020 circa 170 kton mest. Door twee opeenvolgende scheidingsstappen gevolgd door indikking, wordt de mest volgens opgave van Merensteyn op massabasis verwerkt tot circa $20 \%$ dikke fractie, $34 \%$ NK-concentraat en $46 \%$ loosbaar water.

Merensteyn maakt deel uit van de pilot Mineralenconcentraat dat in het kader van het $6^{\mathrm{e}}$ actieprogramma van de Nederlandse Actieprogramma Nitraatrichtlijn wordt uitgevoerd. Het geproduceerde NK-concentraat wordt grotendeels in de regio, binnen 25 km afstand van Merensteyn, afgezet. De dikke fractie, die rijk is aan fosfaat en organische stof, wordt afgezet naar Duitsland en Frankrijk (tussen de 150 en 550 km van Merensteyn). Dit omdat de regio rondom Merensteyn een fosfaatoverschot heeft in de vorm van dierlijke mest die niet in de landbouw plaatsbaar is. De afnemers van de dikke fractie, akkerbouwers in Frankrijk en Duitsland, willen de dikke fractie graag hebben voor bemesting van hun grond. Ook zijn er bedrijven in Duitsland die de dikke fractie graag afnemen om het te vergisten.

\subsubsection{Technische procesbeschrijving}

Figuur 3.12 toont het processtroomdiagram van de mestverwerkingsinstallatie van Merensteyn. De aangeleverde mest wordt opgeslagen in mestzakken. Daarna wordt het versneden om grove delen te verkleinen en komt het uit in de reactortank. Vervolgens scheidt een zeefbandpers de mest in een dikke en dunne fractie. De dikke fractie wordt met infraroodstraling, geproduceerd door propaanbranders, voor 11 minuten bij $61^{\circ} \mathrm{C}$ gehygiëniseerd. Voor de scheiding op de zeefbandpers werden ten tijde van de bemonsteringen ijzersulfaatoplossing $\left(\mathrm{Fe}_{2}\left(\mathrm{SO}_{4}\right)_{3}\right)$, zwavelzuur en polymeeroplossing (een polyacrylamide) toegevoegd om coagulatie en flocculatie te laten optreden.

Een DAF, waaraan ook ijzersulfaatoplossing, zwavelzuur en polymeeroplossing worden toegediend, behandelt de afgescheiden dunne fractie verder. De daar afgescheiden drijflaag wordt teruggepompt naar de reactortank voor de zeefbandpers. Het effluent van de DAF stroomt over twee in serie geplaatste papierfilters met een poriediameter van $8 \mu \mathrm{m}$. Dit is een procesveiligheidsfilter om eventueel resterende deeltjes af te vangen en daarmee verstopping van de membranen van de RO te voorkomen. Merensteyn werkt met twee in serie geschakelde RO's, die beide bestaan uit drie 'stages', waarbij de tweede RO het concentraat van de eerste RO verder behandelt. Op beide RO's wordt geen zuur gedoseerd. Ionenwisselaars zuiveren het samengevoegde permeaat van beide RO's tot loosbaar water. Dit water wordt geloosd op een snelstromende sloot van waaruit het uiteindelijk in de Maas terechtkomt. 


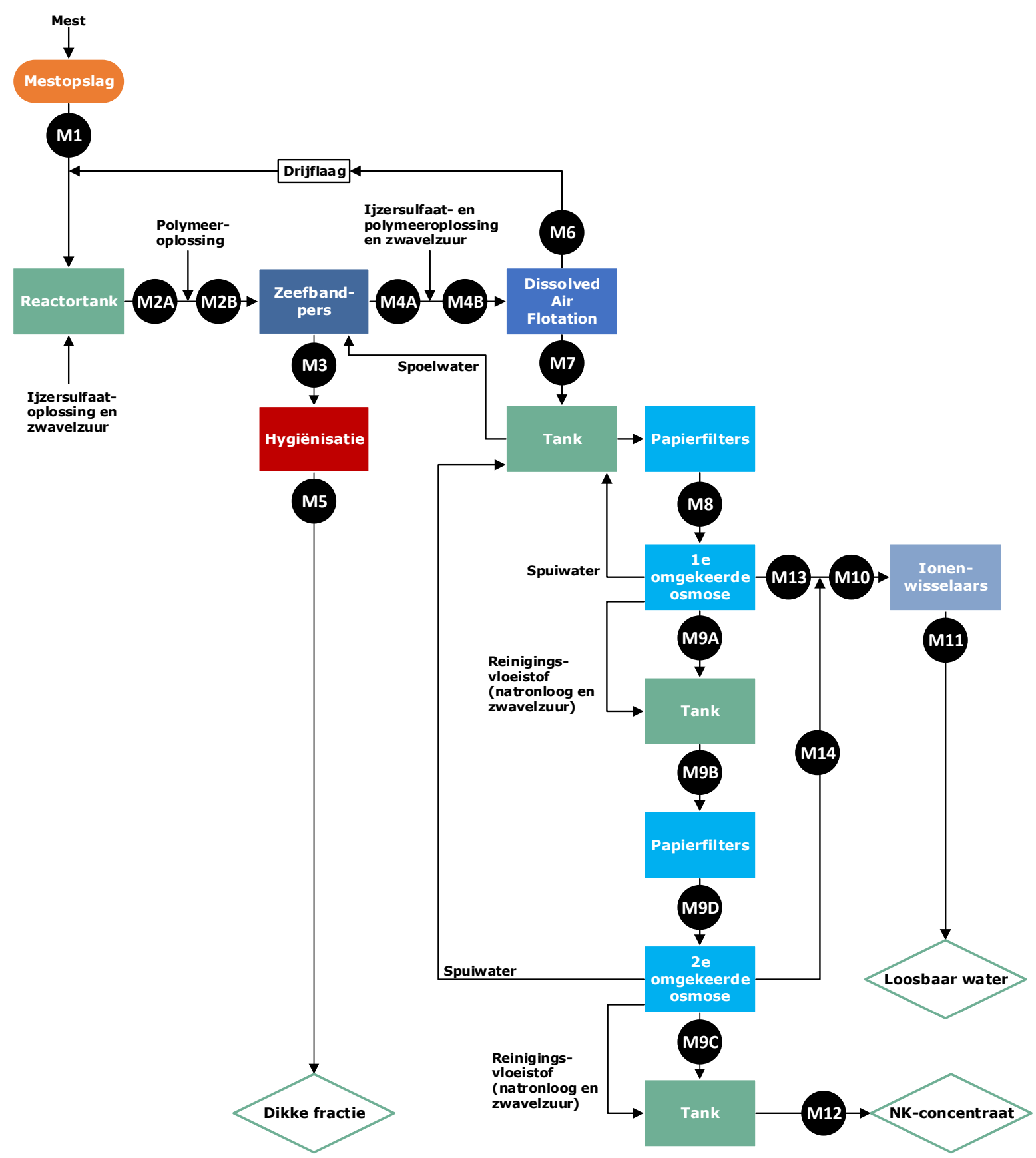

Figuur 3.12 Processtroomdiagram van de mestverwerkingsinstallatie van Merensteyn; bemonsteringspunten zijn aangegeven met een letter-nummercombinatie.

\subsubsection{Scheidingsrendementen}

\subsubsection{Zeefbandpers en hygiënisatie}

Tabel 3.20 toont de samenstelling van de in-en uitgaande stromen en de berekende scheidingsrendementen van de zeefbandpers van Merensteyn. Door de toevoeging van $\mathrm{Fe}_{2}\left(\mathrm{SO}_{4}\right)_{3}-$ oplossing en zwavelzuur zijn in het influent van de zeefbandpers de concentraties zwavel en ijzer respectievelijk 1,2 en $0,72 \mathrm{~g} / \mathrm{kg}$ hoger dan in de ingaande mest. De zeefbandpers scheidt $89 \%$ van de organische stof, $95 \%$ van het fosfaat en $40 \%$ van de stikstof af naar de dikke fractie. Kalium en $\mathrm{N}-\mathrm{NH}_{4}$ gaan voor respectievelijk $19 \%$ en $27 \%$ naar de dikke fractie. De som van de scheidingsrendementen naar de dunne en dikke fractie ligt voor alle componenten dicht bij de 100\%. De som van de massa's dunne fractie $(993 \mathrm{~kg})$ en dikke fractie $(201 \mathrm{~kg})$ is groter dan $1000 \mathrm{~kg}$ door de toevoeging van slib van de $\mathrm{DAF}, \mathrm{Fe}_{2}\left(\mathrm{SO}_{4}\right)_{3}$-oplossing, zwavelzuur en polymeeroplossing. 
De zeefbandpers wordt via spuitkoppen continu, circa $3 \mathrm{~m}^{3}$ per uur, gespoeld met effluent van de DAF. Dit is ongeveer $10 \%$ van het ingaande debiet van de DAF. Dit spoelwater wordt op de zeefbandpers gespoten nadat de dikke fractie eraf is en nadat er nog een schraper overheen is gegaan. Het spuiten heeft als doel de poriën van de zeefband weer schoon te maken en daardoor te openen. Het spoelwater valt voor het overgrote deel in de opvangbak onder de zeefbandpers en wordt daarmee onderdeel van de dunne fractie van de zeefbandpers.

De dikke fractie van de zeefbandpers wordt gehygiëniseerd met infrarode straling bij $61^{\circ} \mathrm{C}$. De gemiddelde concentraties na hygiënisatie waren een klein beetje hoger dan ervoor, maar zo weinig dat het geen verschil te noemen is (Tabel B1.2 in Bijlage 1). De lichte stijging komt waarschijnlijk door de verdamping van water. Er was, gecorrigeerd voor de lichte stijging in drogestofgehalte, geen sprake van een afname in het gehalte stikstof of $\mathrm{N}-\mathrm{NH}_{4}$ tijdens de hygiënisatie. Het monster is direct na de hygiënisatie-unit genomen en de tijdsduur van hygiëniseren (11 minuten) was wellicht te kort om te leiden tot meetbare ammoniakverliezen. Of er veranderingen in het gehalte $\mathrm{N}-\mathrm{NH}_{4}$ optreden tijdens het afkoelen en de opslag van de dikke fractie is niet onderzocht.

Tabel 3.20 Samenstelling van de in- en uitgaande stromen van de zeefbandpers van Merensteyn en het berekende scheidingsrendement als percentage van de ingaande mest; voor de som tussen haakjes de standaardafwijking. Gemiddelde van drie bemonsteringen. ${ }^{1}$

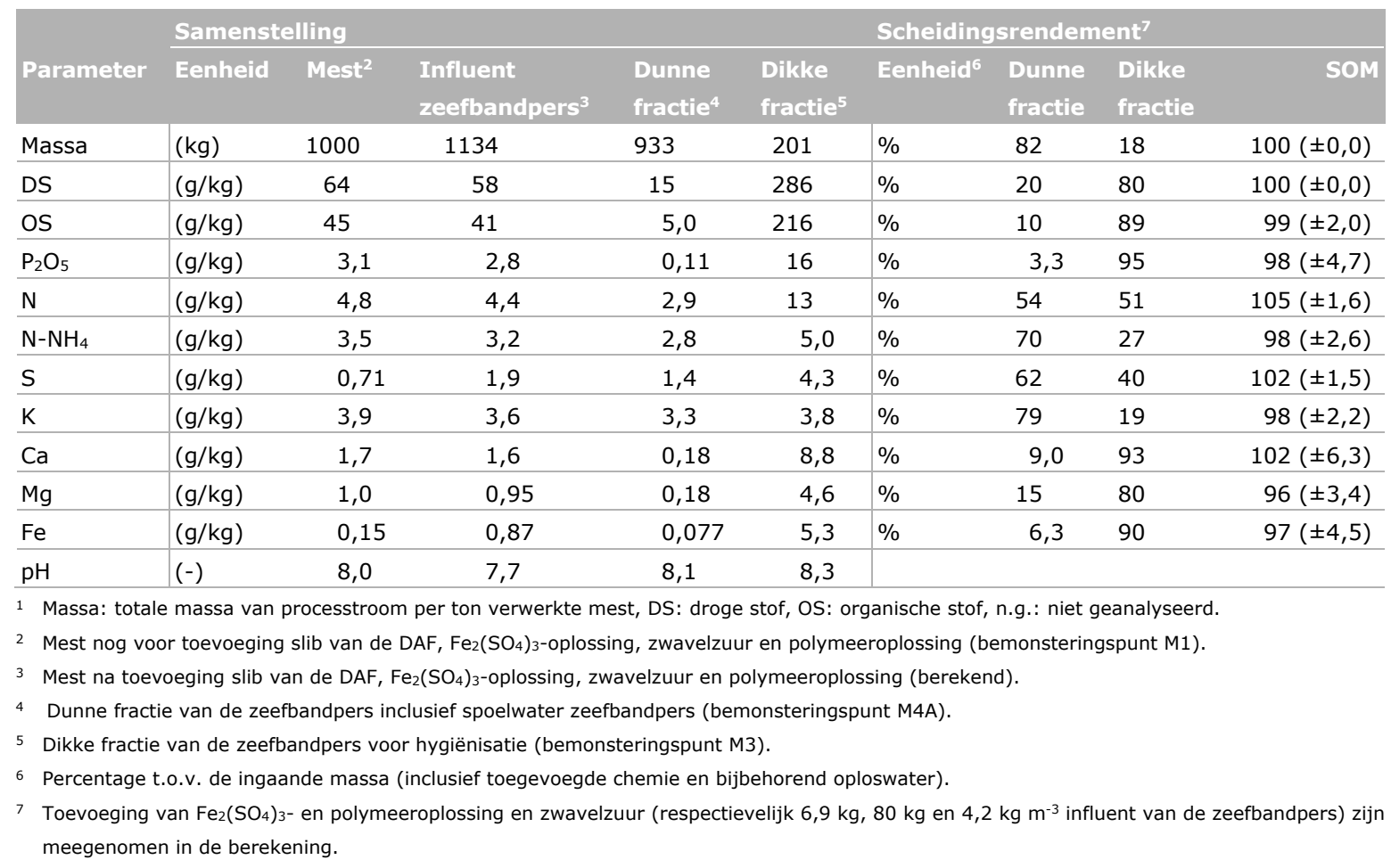

\subsubsection{Dissolved Air Flotation-installatie en papierfilters}

De dunne fractie van de zeefbandpers wordt behandeld door een DAF waar door toevoeging van $\mathrm{Fe}_{2}\left(\mathrm{SO}_{4}\right)_{3}$-oplossing, zwavelzuur en polymeeroplossing in combinatie met beluchting fijne deeltjes via de gevormde drijflaag worden afgevangen door schrapers. Door deze toevoegingen zijn de ijzer- en zwavelgehalten voor de DAF respectievelijk toegenomen van 0,077 naar 0,17 g/kg en van 1,4 naar $1,8 \mathrm{~g} / \mathrm{kg}$ ten opzichte van het effluent van de zeefbandpers. De samenstelling van de in- en uitgaande stromen van de DAF van Merensteyn en het berekende scheidingsrendement als percentage van het influent van de DAF zijn getoond in Tabel 3.21. De DAF scheidt circa 33\% van de organische stof af naar het slib van de DAF. Daardoor daalt het gehalte organische stof van $5,2 \mathrm{~g} / \mathrm{kg}$ naar 4,0 g/ $\mathrm{kg}$. Dit is van belang om verstopping van de $\mathrm{RO}$ te voorkomen. Door toevoeging van $\mathrm{Fe}_{2}\left(\mathrm{SO}_{4}\right)_{3}$-oplossing en zwavelzuur voor de DAF is het gehalte ijzer en zwavel in het influent van de DAF respectievelijk met 0,09 en $0,4 \mathrm{~g} / \mathrm{kg}$ toegenomen ten opzichte van de dunne fractie van de zeefbandpers. 
Het effluent van de DAF stroomt naar een opslagtank met een volume van $25 \mathrm{~m}^{3}$ waar ook periodiek in wisselende hoeveelheden spuiwater van de RO's naar wordt teruggevoerd, waardoor verdunning optreedt. De inhoud van de opslagtank wordt over twee, in serie geschakelde, papierfilters geleid wat niet resulteert in een relevante verandering van de samenstelling van de vloeistof, zie daarvoor Tabel B1.3 in Bijlage 1.

Tabel 3.21 Samenstelling van de in- en uitgaande stromen van de DAF-installatie van Merensteyn en het berekende scheidingsrendement als percentage van het influent van de DAF. Gemiddelde van minimaal één bemonstering. ${ }^{1}$

\begin{tabular}{|c|c|c|c|c|c|c|c|c|}
\hline \multirow{3}{*}{ Parameter } & \multicolumn{4}{|c|}{ Samenstelling } & \multicolumn{4}{|c|}{ Scheidingsrendement ${ }^{6}$} \\
\hline & \multirow[t]{2}{*}{ Eenheid } & \multirow{2}{*}{$\begin{array}{l}\text { Influent } \\
\text { DAF2 }\end{array}$} & \multirow[t]{2}{*}{ Effluent $D A F^{3}$} & \multirow[t]{2}{*}{ Slib DAF 4} & \multirow[t]{2}{*}{ Eenheid ${ }^{5}$} & \multirow{2}{*}{$\begin{array}{l}\text { Dunne } \\
\text { fractie }\end{array}$} & \multirow{2}{*}{$\begin{array}{l}\text { Dikke } \\
\text { fractie }\end{array}$} & \multirow[t]{2}{*}{ SOM } \\
\hline & & & & & & & & \\
\hline DS & $(\mathrm{g} / \mathrm{kg})$ & 16 & 15 & 64 & $\%$ & 85 & 15 & 100 \\
\hline os & $(\mathrm{g} / \mathrm{kg})$ & 5,2 & 4,0 & 44 & $\%$ & 52 & 33 & 84 \\
\hline $\mathrm{N}$ & $(\mathrm{g} / \mathrm{kg})$ & 3,0 & 2,9 & 4,8 & $\%$ & 89 & 6,8 & 96 \\
\hline $\mathrm{N}-\mathrm{NH}_{4}$ & $(\mathrm{~g} / \mathrm{kg})$ & 2,7 & 2,7 & 3,6 & $\%$ & 96 & 5,4 & 101 \\
\hline $\mathrm{S}$ & $(\mathrm{g} / \mathrm{kg})$ & 1,8 & 1,8 & 1,2 & $\%$ & 96 & 2,4 & 98 \\
\hline $\mathrm{K}$ & $(\mathrm{g} / \mathrm{kg})$ & 3,2 & 3,2 & 3,7 & $\%$ & 91 & 4,5 & 96 \\
\hline $\mathrm{pH}$ & $(-)$ & 7,9 & 7,9 & 8,1 & - & - & - & - \\
\hline \multicolumn{9}{|c|}{1 Massa: totale massa van processtroom per ton verwerkte mest, DS: droge stof, OS: organische stof, n.g.: niet geanalyseerd. } \\
\hline \multicolumn{9}{|c|}{$\begin{array}{l}2 \text { Dunne fractie van de zeefbandpers na toevoeging } \mathrm{Fe}_{2}\left(\mathrm{SO}_{4}\right)_{3} \text {-oplossing, zwavelzuur en polymeeroplossing (bemonsteringspunt M4B); } \\
\text { gemiddelde van drie bemonsteringen. }\end{array}$} \\
\hline \multicolumn{9}{|c|}{3 Effluent van de DAF voor opslagtank (bemonsteringspunt M7); gemiddelde van drie bemonsteringen. } \\
\hline \multicolumn{9}{|c|}{$\begin{array}{l}4 \text { Afgepompt slib van de DAF uit de opvangbak waar het over de rand van DAF in wordt geschraapt (bemonsteringspunt M6); waarden van } \\
\text { alleen de } 3^{\mathrm{e}} \text { bemonstering, omdat de monsters van de } 1^{\mathrm{e}} \text { en } 2^{\mathrm{e}} \text { bemonstering niet op een representatieve locatie zijn genomen. }\end{array}$} \\
\hline \multicolumn{9}{|c|}{5 Percentage t.o.v. de ingaande massa (inclusief toegevoegde chemie en bijbehorend oploswater). } \\
\hline \multicolumn{9}{|c|}{ 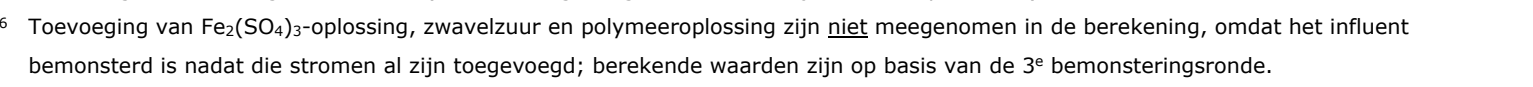 } \\
\hline \multicolumn{9}{|c|}{$\begin{array}{l}7 \text { Bij de drie bemonsteringen zaten zowel waarden onder als boven de kwantificeringslimiet (LOQ), voor berekening van het gemiddelde zijn } \\
\text { waarden onder de LOQ gehanteerd als } L O Q / \sqrt{ } 2 \text {. }\end{array}$} \\
\hline
\end{tabular}

\subsubsection{Omgekeerde osmose-installatie}

Merensteyn heeft twee in serie geschakelde RO's, die beide bestaan uit drie 'stages'. De eerste RO opereert bij een druk van 40 tot 55 bar, afhankelijk van de vervuilingsgraad, en bereikt een concentraat met een geleidbaarheid van circa $52 \mathrm{mS} / \mathrm{cm}$. Het concentraat van de eerste RO wordt in de tweede RO verder geconcentreerd bij een druk van 60 bar tot een geleidbaarheid van circa $70 \mathrm{~ms} / \mathrm{cm}$.

Een deel van het permeaat van de tweede 'stages' van beide RO's wordt als spuiwater teruggevoerd naar de opslagtank van $25 \mathrm{~m}^{3}$ tussen de DAF en de papierfilters. Daarmee wordt het influent van de papierfilters voor de eerste RO dus verdund. Het debiet van deze stroom wordt niet gemeten en deze stroom is ook niet bemonsterd. Daarom is het berekend op basis van het verschil in kaliumconcentratie tussen het effluent van de DAF en het permeaat van de eerste van de twee papierfilters. Dit onder de aanname dat de gehalten in het spuiwater verwaarloosbaar zijn ten opzichte van het effluent van de DAF. Dit spuiwater is berekend op circa $13 \%$ van het influent debiet van de eerste RO.

Alle ingaande componenten (droge stof, organische stof en zouten) eindigen nagenoeg volledig in het concentraat van de tweede RO of het spuiwater van de tweede 'stages' van beide RO's. Tabel 3.22 toont daarom de samenstelling van de in- en uitgaande stromen van beide gecombineerde RO's en de berekende concentratiefactor i.p.v. de scheidingsrendementen. De concentratiefactoren voor droge stof en organische stof worden als minder betrouwbaar gezien in stromen die aanzienlijke gehalten $\mathrm{N}$ - 
$\mathrm{NH}_{4}$ bevatten, omdat dit kan verdampen tijdens de bepaling van het gehalte droge stof en organische stof. Op basis van de overige componenten ligt de berekende concentratiefactor over de twee in serie geplaatste RO's tussen de 3 (stikstof) en 3,6 (zwavel). Zwavelzuur wordt gedoseerd voor de DAF en niet op de RO installatie zelf. Het effluent (permeaat) van beide RO's bevat samengevoegd gemiddeld $9,9 \mathrm{mg} \mathrm{N}-\mathrm{NH}_{4}$ per liter.

Beide RO's worden ongeveer om de vier cycli automatisch gereinigd met natronloog en zwavelzuur. Dit reinigingswater - met een onbekende omvang - wordt toegevoegd aan de opslagsilo met het NKconcentraat (concentraat van de tweede RO).

Tabel 3.22 Samenstelling van de in- en uitgaande stromen van de omgekeerde osmose-installatie van Merensteyn en de berekende concentratiefactor daarvan. Gemiddelde van drie bemonsteringen. ${ }^{1}$

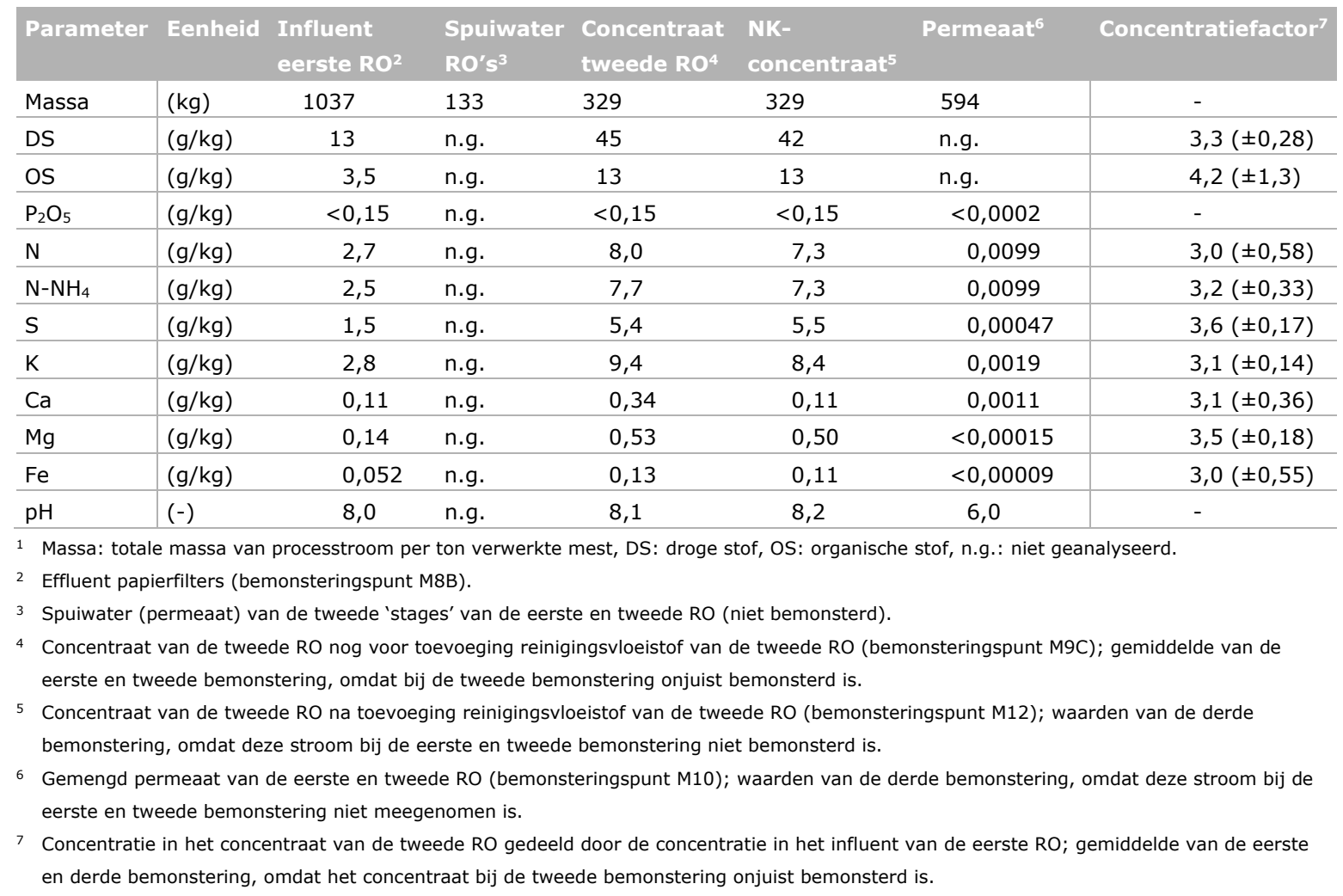

\subsubsection{Ionenwisselaars}

Als veiligheidsfilter ter voorkoming van te hoge concentraties $\mathrm{N}-\mathrm{NH}_{4}$ of andere zouten in het te lozen water, wordt het permeaat van de eerste en tweede RO bij elkaar gevoegd over ionenwisselaars geleid. Tabel 3.23 toont de samenstelling van het influent en effluent van de ionenwisselaars van Merensteyn. Concentraties van $\mathrm{N}-\mathrm{NH}_{4}$ en andere zouten zijn al voorafgaand aan de ionenwisselaars zeer laag. Bij de tweede en derde bemonstering waren de gehalten in het influent van de ionenwisselaars iets lager dan het effluent van de ionenwisselaars. De foutmarge op de chemische analyses kan hier een reden voor zijn. Ook is het influent van de ionenwisselaars qua samenstelling afhankelijk van of de eerste en tweede RO op het moment van bemonsteren beide produceren, of alleen één van die twee. Dat kan temporele variaties in de gehalten in het influent van de ionenwisselaars veroorzaken. Door bovenstaande kan het verwijderingspercentage van de ionenwisselaars niet worden bepaald. De ionenwisselaars worden volgens opgave van Merensteyn eens per halfjaar geregenereerd, wat heel grofweg neerkomt op eens per $50.000 \mathrm{~m}^{3}$ geloosd water. 
Tabel 3.23 Samenstelling van het influent en effluent van de ionenwisselaars van Merensteyn. Gemiddelde van drie bemonsteringen. ${ }^{1}$

\begin{tabular}{llcc} 
Parameter & Eenheid & Influent ionenwisselaars & Effluent ionenwisselaars ${ }^{2}$ \\
Massa & $(\mathrm{kg})$ & 594 & 594 \\
\hline $\mathrm{DS}$ & $(\mathrm{g} / \mathrm{kg})$ & - & - \\
\hline $\mathrm{OS}$ & $(\mathrm{g} / \mathrm{kg})$ & - & $<0,0002$ \\
\hline $\mathrm{P}_{2} \mathrm{O}_{5}$ & $(\mathrm{~g} / \mathrm{kg})$ & $<0,0002$ & 0,012 \\
\hline $\mathrm{N}$ & $(\mathrm{g} / \mathrm{kg})$ & 0,0099 & 0,012 \\
\hline $\mathrm{N}-\mathrm{NH}_{4}$ & $(\mathrm{~g} / \mathrm{kg})$ & 0,0099 & 0,00039 \\
\hline $\mathrm{S}$ & $(\mathrm{g} / \mathrm{kg})$ & 0,00047 & 0,0022 \\
\hline $\mathrm{K}$ & $(\mathrm{g} / \mathrm{kg})$ & 0,0019 & $<0,0012$ \\
\hline $\mathrm{Ca}$ & $(\mathrm{g} / \mathrm{kg})$ & 0,0011 & $<0,00015$ \\
\hline $\mathrm{Mg}$ & $(\mathrm{g} / \mathrm{kg})$ & $<0,00015$ & $<0,00009$ \\
\hline Fe & $(\mathrm{g} / \mathrm{kg})$ & $<0,00009$ & 5,7 \\
\hline $\mathrm{pH}$ & $(-)$ & 6,0 &
\end{tabular}

\subsubsection{Massabalans}

Een massabalans is opgesteld op basis van de gemeten samenstellingen van de genomen monsters, de daaruit berekende scheidingsrendementen en de gegevens over het chemieverbruik. De retourstroom van het slib van de DAF is door middel van iteratie berekend. Figuur 3.13 en Figuur 3.14 tonen de stroomdiagrammen voor de totale massa van de verwerkte mest en de parameters stikstof, fosfaat en kalium. 


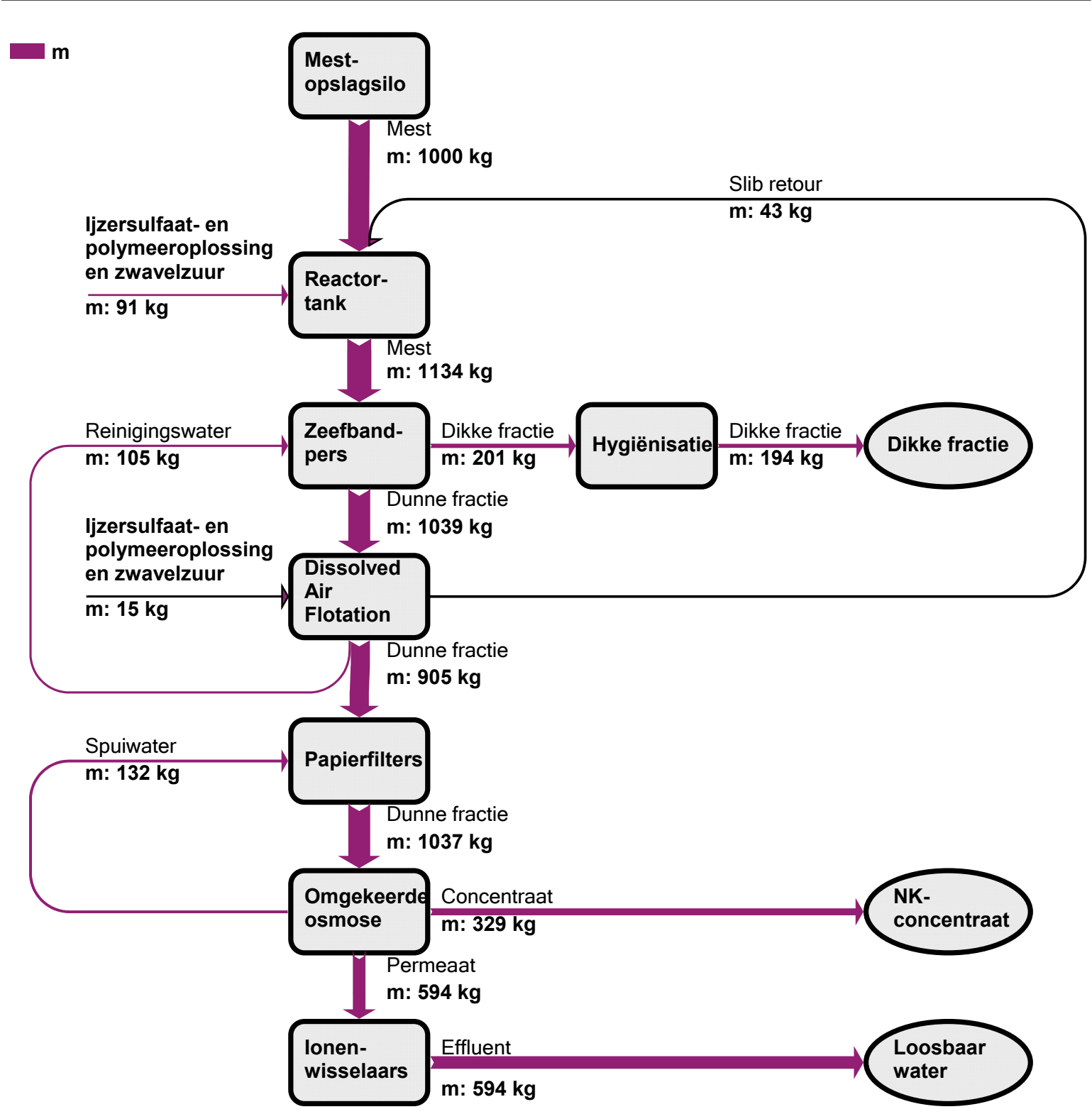

Figuur 3.13 Sankey-diagram van de totale massa $(\mathrm{m})$ per $1000 \mathrm{~kg}$ verwerkte varkensdrijfmest van de mestverwerkingsinstallatie van Merensteyn op basis van berekende debieten zonder uitbalancering, daarom is de som van uitgaande stromen niet precies gelijk aan de som van ingaande stromen.

Circa 30\% van de ingaande mest inclusief de toegevoegde chemie eindigt in het NK-concentraat. Deze berekende 329 kg NK-concentraat is in lijn met de $340 \mathrm{~kg} \mathrm{NK}$-concentraat die Merensteyn zelf heeft gemeten op basis van de boekhouding van vrachtwagenritten. De massa van de eindproducten uit één ton mest bedraagt tezamen $1106 \mathrm{~kg}$ door toevoeging van $106 \mathrm{~kg}$ aan chemie $\left(\mathrm{Fe}_{2}\left(\mathrm{SO}_{4}\right)_{3}\right.$, polymeer en zwavelzuur) en bijbehorend oploswater. De massa van de dikke fractie en het NK-concentraat is samen $523 \mathrm{~kg}$ per ton ingaande mest. De per as te transporteren massa is dus met $48 \%$ verminderd ten opzichte van de ingaande mest. 


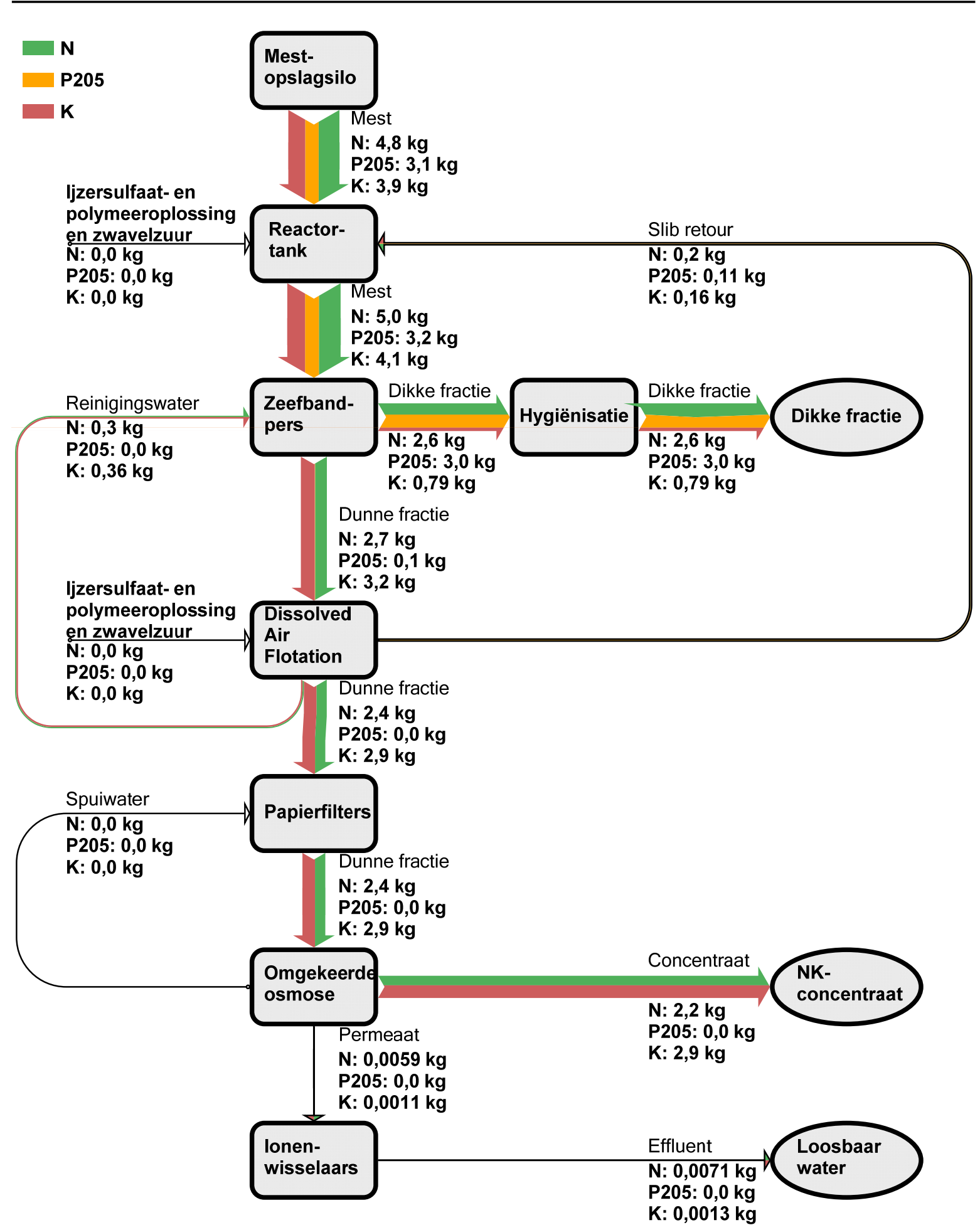

Figuur 3.14 Sankey-diagram van de massa totaalstikstof $(N)$, totaalfosfaat $\left(P_{2} O_{5}\right)$ en totaalkalium (K) per $1000 \mathrm{~kg}$ verwerkte varkensdrijfmest van de mestverwerkingsinstallatie van Merensteyn; op basis van berekende debieten, vermenigvuldigd met gemeten concentraties zonder uitbalancering, daarom is de som van uitgaande stromen niet precies gelijk aan de som van ingaande stromen.

Uit Figuur 3.14 volgt dat nagenoeg 100\% van het ingaande fosfaat terechtkomt in de dikke fractie van de zeefbandpers. Circa $54 \%$ en $20 \%$ van respectievelijk de ingaande stikstof en kalium eindigen daar ook. Van de ingaande stikstof komt circa $46 \%$ terecht in het NK-concentraat. Het permeaat van de RO's bevat op massabalansbasis een verwaarloosbare hoeveelheid stikstof, fosfaat en kalium. De uitgaande stromen bevatten gezamenlijk volgens de gebruikte berekeningsmethode circa $10 \%$ meer stikstof en circa $10 \%$ minder kalium dan het totaal van de ingaande stromen. Dit is een onzekerheid in de opgestelde massabalans en kan niet worden gezien als een werkelijke toename of afname aan deze componenten. Gezamenlijk bevatten het NK-concentraat en het permeaat van de RO circa $6 \%$ minder 
stikstof dan het influent van de RO. In ieder geval een deel van deze $6 \%$ zal in het spuiwater van de tweede 'stages' van de RO's zitten, die niet bemonsterd is.

Tabel 3.24 toont de berekende massabalans per $1000 \mathrm{~kg}$ verwerkte varkensdrijfmest van de mestverwerkingsinstallatie van Merensteyn. Het totaal aan eindproducten als percentage van de ingaande mest plus toegevoegde chemie en bijbehorend oploswater ligt voor alle componenten in de buurt van $100 \%$, met een maximale afwijking van $9 \%$, behalve voor ijzer.

Tabel 3.24 Massabalans van de mestverwerkingsinstallatie van Merensteyn in $\mathrm{kg}$ per ton ingaande mest, gemiddelde van drie bemonsteringen. ${ }^{1}$

\begin{tabular}{|c|c|c|c|c|c|c|}
\hline Parameter & $\begin{array}{l}\text { Mest } \\
(\mathbf{k g})\end{array}$ & $\begin{array}{l}\text { Chemie } 2 \\
\text { (kg) }\end{array}$ & $\begin{array}{l}\text { Dikke fractie } \\
\text { (kg) }\end{array}$ & $\begin{array}{l}\text { NK-concentraat } \\
\text { (kg) }\end{array}$ & $\begin{array}{l}\text { Loosbaar water } \\
(\mathrm{kg})\end{array}$ & $\begin{array}{l}\text { Totaal eindproducten } \\
(\%)\end{array}$ \\
\hline Massa & 1000 & 106 & 201 & 329 & 594 & $102 \%$ \\
\hline DS & 64 & - & 53 & 11 & & $101 \%$ \\
\hline OS & 45 & - & 42 & 2,5 & & $98 \%$ \\
\hline $\mathrm{P}_{2} \mathrm{O}_{5}$ & 3,1 & - & 3,0 & $<0,049$ & & $98 \%$ \\
\hline $\mathrm{N}$ & 4,8 & - & 2,6 & 2,2 & & $100 \%$ \\
\hline $\mathrm{N}-\mathrm{NH}_{4}$ & 3,5 & - & 0,99 & 2,4 & & $99 \%$ \\
\hline $\mathrm{S}$ & 0,71 & 2,1 & 0,87 & 2,2 & & $109 \%$ \\
\hline $\mathrm{K}$ & 3,9 & - & 0,79 & 2,9 & & $94 \%$ \\
\hline $\mathrm{Ca}$ & 1,7 & - & 1,7 & 0,11 & & $106 \%$ \\
\hline $\mathrm{Mg}$ & 1,0 & - & 0,87 & 0,15 & & $97 \%$ \\
\hline $\mathrm{Fe}$ & 0,15 & 0,99 & 0,89 & 0,034 & & $81 \%$ \\
\hline \multicolumn{7}{|c|}{1 Massa: totale massa van processtroom per ton verwerkte mest, DS: droge stof, OS: organische stof, n.g.: niet geanalyseerd. } \\
\hline 2 Chemie: total & le toegevo & de massa aan & $\mathrm{e}_{2}\left(\mathrm{SO}_{4}\right)_{3}$-oplossing & lymeeroplossing en zwa & velzuur (exclusief voor & de reiniging van de RO's). \\
\hline 3 Als percentag & & & counod o ho & hohorend onlocis & & \\
\hline
\end{tabular}

\subsubsection{Chemie- en energieverbruik}

Ten tijde van de bemonsteringen werd voor de zeefbandpers circa 6,9 kg 42\% $\mathrm{Fe}_{2}\left(\mathrm{SO}_{4}\right)_{3}(2,9 \mathrm{~kg}$ $\left.\mathrm{Fe}_{2}\left(\mathrm{SO}_{4}\right)_{3}\right)$ en circa 80 liter kationische polymeeroplossing $(0,25 \mathrm{~kg}$ poeder $)$ toegevoegd per ton influent van de zeefbandpers. Ook werd daar 4,2 kg van $50 \%$ zwavelzuur toegevoegd per ton influent van de zeefbandpers. Daarnaast werd voor de DAF circa 1,5 kg 42\% Fe ${ }_{2}\left(\mathrm{SO}_{4}\right)_{3}\left(0,63 \mathrm{~kg} \mathrm{Fe} 2\left(\mathrm{SO}_{4}\right)_{3}\right)$ en circa $3,4 \mathrm{~kg} 50 \% \mathrm{H}_{2} \mathrm{SO}_{4}$ toegevoegd per ton influent van de DAF. Ook wordt daar circa $10 \mathrm{~kg}$ kationische polymeeroplossing $(0,020 \mathrm{~kg}$ poeder $)$ toegevoegd per ton influent van de DAF.

Uitgedrukt per ton ingaande mest en omgerekend naar de hoeveelheid werkzame stof in de chemievloeistoffen werd ten tijde van de bemonsteringen in totaal circa 3,7 kg (droog) $\mathrm{Fe}_{2}\left(\mathrm{SO}_{4}\right)_{3}-$ poeder, $90 \mathrm{~kg}$ polymeeroplossing $(0,27 \mathrm{~kg}$ poeder) en $7,7 \mathrm{~kg} \mathrm{50 \%} \mathrm{zwavelzuur} \mathrm{(1,3} \mathrm{kg} \mathrm{zwavel)}$ toegevoegd.

De hygiënisatie van de dikke fractie gebeurt met infrarood door middel van propaan-gestookte gasbranders. Het propaanverbruik en het totale elektriciteitsverbruik van de mestverwerkingsinstallatie zijn bekend, maar is bedrijfseigen informatie.

\subsection{Ecoson}

\subsubsection{Algemene beschrijving}

De digestaatverwerkingsinstallatie van Ecoson is gelegen in Son (Noord-Brabant), op hetzelfde terrein als Rendac Son. Beide bedrijven zijn onderdeel van het Amerikaans beursgenoteerde bedrijf Darling Ingredients dat zich richt op het produceren van hoogwaardige ingrediënten uit organische restmaterialen voor toepassing in verschillende industrieën, zoals de farmaceutische, de voedingsmiddelen- en de diervoedingsindustrie. Rendac Son verwerkt en vernietigt al enkele decennia 
kadavers en dierlijk restmateriaal met als doel dierziekte- en volksgezondheidsrisico's te voorkomen en het omzetten van de eindproducten daarvan in hernieuwbare energie en brandstoffen. In 2007 is de locatie in Son uitgebreid met het bedrijf Ecoson. De gebouwde installatie van Ecoson was in eerste instantie gericht op de productie van grondstoffen voor biodiesel en de productie van hernieuwbare energie uit reststromen uit de levensmiddelenindustrie. Sinds 2014 wordt door Ecoson in samenwerking met ZLTO en het bedrijf Mestac circa 100 kton varkensdrijfmest en 25 kton ongeboren varkensmest per jaar vergist. Jaarlijks wordt daarmee 4,5 miljoen $\mathrm{m}^{3}$ biogas $\left(65\right.$ vol.-\% $\mathrm{CH}_{4}$ ) geproduceerd dat verder opgewerkt wordt tot 2,5 miljoen $\mathrm{m}^{3}$ groen gas dat geleverd wordt aan het gasnet. Deze hoeveelheid is gelijk aan het jaarlijkse aardgasverbruik van circa 1.900 huishoudens. Na de vergisting van de mest blijft digestaat over. In de eerste jaren van Ecoson lag de focus op de verwaarding van de dikke fractie van het digestaat en het daarin aanwezige fosfaat. Dit vanwege het overschot aan fosfaat in Noord-Brabant ten opzichte van de hoeveelheid die op landbouwgrond mag worden opgebracht. Daarom is Ecoson mestkorrels gaan produceren, een fosfaatrijke organische meststof, die goedkoper transporteerbaar en makkelijker afzetbaar is dan dikke fractie. In 2017 is er meer aandacht gekomen voor de verwerking van de dunne fractie van het geproduceerde digestaat. $\mathrm{Er}$ is niet gekozen om uit de dunne fractie een NK-concentraat te produceren, aangezien de afzet ervan lastig is. Er is alleen vraag naar tijdens uitrijdperioden waardoor een grote opslagcapaciteit nodig is, hetgeen relatief hoge kosten met zich meebrengt. In plaats daarvan is gekozen voor zuivering van de dunne fractie tot loosbaar water, aangezien de locatie een eigen afvalwaterzuiveringsinstallatie heeft. Bij de zuivering van de dunne fractie ontstonden problemen door de aanwezigheid van humuszuren. Samen met het bedrijf OPURE is een techniek ontwikkeld om deze humuszuren af te scheiden en de zuivering van de dunne fractie operationeel stabiel te maken.

\subsubsection{Technische procesbeschrijving}

Figuur 3.15 geeft het processtroomdiagram weer van de digestaatverwerkingsinstallatie van Ecoson. Een decanter centrifuge scheidt, met toevoeging van polymeeroplossing, het digestaat in een dikke en dunne fractie. De dikke fractie wordt door een banddroger en schijvendroger gedroogd en daarna tot mestkorrels geperst. De damp van de banddroger wordt gezuiverd door een luchtwasser en daarna uitgeblazen naar de buitenlucht. De damp van de schijvendroger wordt gecondenseerd waarna het condensaat naar de afvalwaterzuivering gaat en de overgebleven damp ook over de luchtwasser wordt geleid. De dunne fractie gaat naar de humuszuurinstallatie (HZI), die bestaat uit achtereenvolgens een zeef, beluchte biologische reactor, een membraanbioreactor (MBR) en een nanofiltratie- (NF) installatie. De biologische reactor heeft als doel het organischestofgehalte (chemisch zuurstofverbruik) te verlagen door biologische afbraak. Hierbij ontstaat ook een slib door groei van bacteriën, wat wordt afgescheiden in de na-geschakelde MBR. Het slib van de MBR wordt met restwarmte gedroogd, tezamen met andere reststromen van Rendac en afgezet als brandstof voor kolencentrales. Het effluent van de MBR stroomt door naar de NF waar humuszuren worden afgescheiden in een concentraat. Ecoson heeft de doelstelling om dit concentraat op termijn naar de landbouw af te zetten als biostimulant. Het permeaat van de NF gaat naar de afvalwaterzuiveringsinstallatie op het terrein die primair is gerealiseerd voor zuivering van afvalwater uit andere bedrijfsactiviteiten. De afvalwaterzuivering bestaat onder andere uit een Anammox- (ANoxische AMMonium OXidatie) installatie, waarmee $\mathrm{N}-\mathrm{NH}_{4}$ tegen een laag elektriciteitsverbruik wordt omgezet naar stikstofgas. De waterzuivering is geen onderdeel van de voor dit rapport uitgevoerde monitoring. 


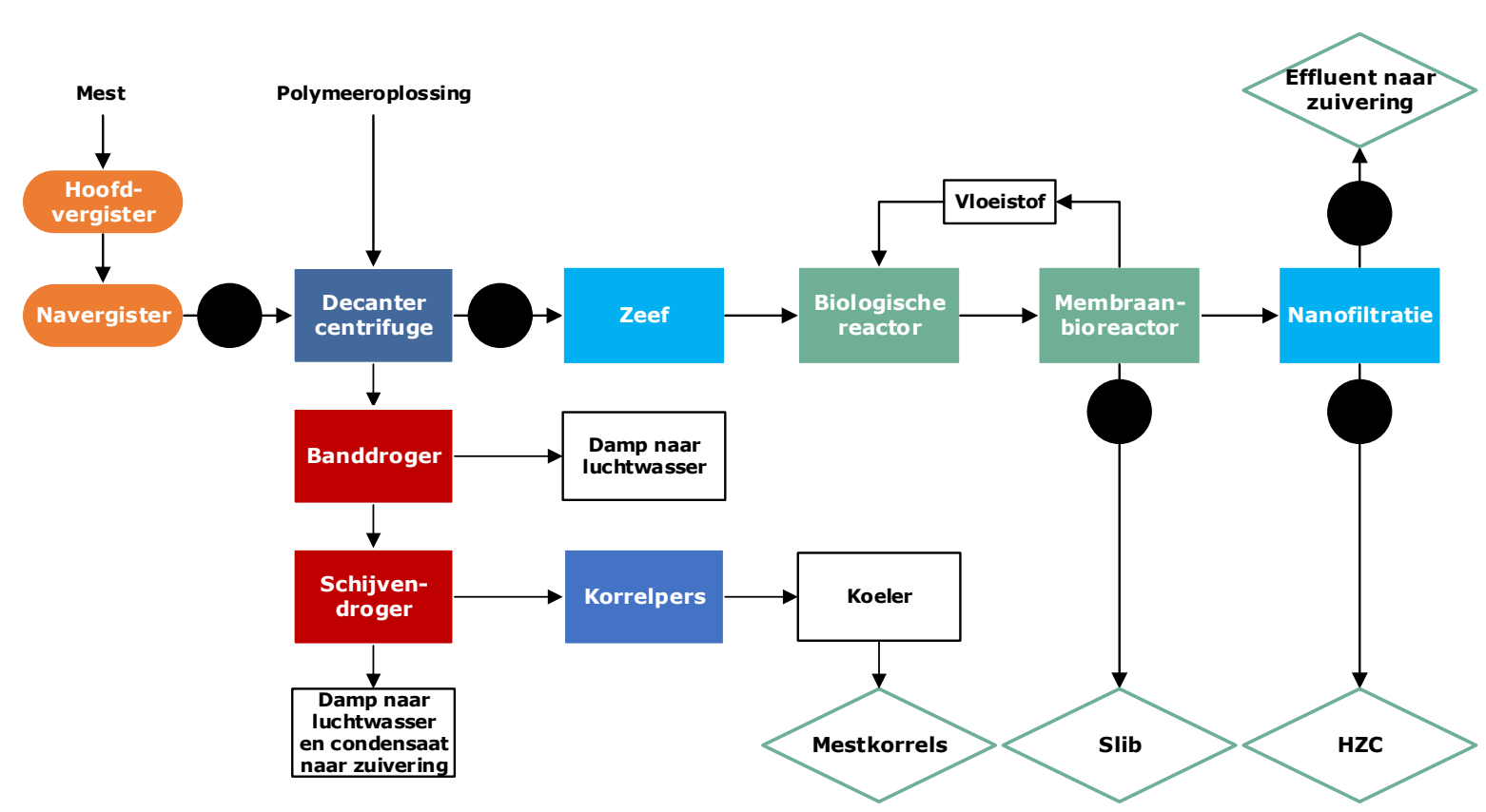

Figuur 3.15 Processtroomdiagram van de digestaatverwerkingsinstallatie van Ecoson; bemonsteringspunten zijn aangegeven met een zwart rondje; HZC: humuszuurconcentraat.

\subsubsection{Scheidingsrendementen}

Ecoson bemonstert de digestaatverwerkingsinstallatie zelf met regelmaat en voert daarvoor ook zelf de chemische analyses uit. Daaruit is door Ecoson zelf een massabalans opgesteld. Door WENR zijn uit die massabalans de scheidingsrendementen berekend. Er is geen bemonstering door WENR uitgevoerd waardoor de massabalans voor een beperkter aantal elementen is opgesteld t.o.v. de andere verwerkers.

\subsubsection{Decanter centrifuge}

Tabel 3.25 toont de samenstelling van de in- en uitgaande stromen en de berekende scheidingsrendementen van de decanter centrifuge van Ecoson. Van de stikstof, het fosfaat en de kalium in het ingaande digestaat komt respectievelijk $43 \%$, $91 \%$ en $26 \%$ terecht in de dikke fractie. Het fosfaatgehalte in de dunne fractie is een factor 10 lager dan in het ingaande digestaat.

Tabel 3.25 Samenstelling van de in- en uitgaande stromen van de decanter centrifuge van Ecoson en het berekende scheidingsrendement als percentage van het ingaande digestaat. Gemiddelde waarden op basis van eigen monitoring door Ecoson. ${ }^{1}$

\begin{tabular}{|c|c|c|c|c|c|c|c|c|}
\hline \multirow[b]{2}{*}{ Parameter } & \multicolumn{4}{|c|}{ Samenstelling } & \multicolumn{4}{|c|}{ Scheidingsrendement ${ }^{6}$} \\
\hline & Eenheid & Digestaat $^{2}$ & Dunne fractie $e^{3}$ & Dikke fractie $^{4}$ & Eenheid ${ }^{5}$ & Dunne fractie & Dikke fractie & SOM \\
\hline Massa & (kg) & 1000 & 820 & 204 & $\%$ & 80 & 20 & 100 \\
\hline DS & $(\mathrm{g} / \mathrm{kg})$ & 72 & 16 & 292 & $\%$ & 18 & 83 & 101 \\
\hline OS & $(\mathrm{g} / \mathrm{kg})$ & 52 & 10 & 232 & $\%$ & 16 & 91 & 107 \\
\hline $\mathrm{P}_{2} \mathrm{O}_{5}$ & $(\mathrm{~g} / \mathrm{kg})$ & 4,3 & 0,40 & 19 & $\%$ & 8,6 & 91 & 100 \\
\hline $\mathrm{N}$ & $(\mathrm{g} / \mathrm{kg})$ & 6,5 & 4,5 & 14 & $\%$ & 57 & 43 & 100 \\
\hline $\mathrm{N}-\mathrm{NH}_{4}$ & $(\mathrm{~g} / \mathrm{kg})$ & n.g. & n.g. & n.g. & & & & \\
\hline $\mathrm{S}$ & $(\mathrm{g} / \mathrm{kg})$ & n.g. & n.g. & n.g. & & & & \\
\hline$\underline{K}$ & $(\mathrm{~g} / \mathrm{kg})$ & 4,4 & 4,2 & 5,5 & $\%$ & 78 & 26 & 104 \\
\hline $\mathrm{Ca}$ & $(\mathrm{g} / \mathrm{kg})$ & n.g. & n.g. & n.g. & & & & \\
\hline $\mathrm{Mg}$ & $(\mathrm{g} / \mathrm{kg})$ & n.g. & n.g. & n.g. & & & & \\
\hline $\mathrm{Fe}$ & $(\mathrm{g} / \mathrm{kg})$ & n.g. & n.g. & n.g. & & & & \\
\hline $\mathrm{pH}$ & $(-)$ & n.g. & n.g. & n.g. & & & & \\
\hline \multicolumn{9}{|c|}{1 Massa: totale massa van processtroom per ton verwerkt digestaat, DS: droge stof, OS: organische stof, n.g.: niet geanalyseerd. } \\
\hline \multicolumn{9}{|c|}{2 Digestaat nog voor toevoeging van polymeeroplossing. } \\
\hline \multicolumn{9}{|c|}{3 Organischestofgehalte is een inschatting van Ecoson i.p.v. een meting. } \\
\hline \multicolumn{9}{|c|}{4 Samenstelling is door Ecoson berekend (als verschilberekening in de massabalans). } \\
\hline \multicolumn{9}{|c|}{5 Percentage t.o.v. de ingaande massa (inclusief toegevoegde chemie en bijbehorend oploswater). } \\
\hline \multicolumn{9}{|c|}{6 Toevoeging van $24 \mathrm{~kg}$ polymeeroplossing per ton ingaand digestaat is meegenomen in de berekening. } \\
\hline
\end{tabular}




\subsubsection{Humuszuurinstallatie}

Tabel 3.26 toont de samenstelling van de in- en uitgaande stromen en de berekende scheidingsrendementen van de HZI van Ecoson. Van de ingaande massa van de HZI eindigt $88 \%$ in het effluent, $10 \%$ in het slib van de MBR en 2,3\% wordt humuszuurconcentraat. Het geproduceerde humuszurenconcentraat bevat hoge concentraties stikstof $(19 \mathrm{~g} / \mathrm{kg})$ en kalium $(11 \mathrm{~g} / \mathrm{kg})$. Vanwege het kleine volume van het humuszuurconcentraat gaat hier toch 'slechts' $10 \%$ van de stikstof en $6,1 \%$ van het kalium naartoe.

De concentraties fosfaat en kalium in het effluent van de HZI zijn vergelijkbaar met die in het influent van de HZI. Het stikstofgehalte in het effluent is echter $24 \%$ lager dan in het influent, omdat een deel als organisch stikstof wordt afgevangen naar het MBR-slib en humuszuurconcentraat. Dit effluent is, zoals Ecoson ook aangeeft, een processtroom met potentie voor toekomstige terugwinning/afscheiding van stikstof, omdat organische stof en fosfaat er al grotendeels uit zijn verwijderd. Nu gaat het effluent naar een afvalwaterzuiveringsinstallatie waar de stikstof biologisch wordt omgezet naar stikstofgas en het fosfaat door toevoeging van chemie wordt verwijderd; het gezuiverde water wordt geloosd.

Het MBR-slib gaat naar een indamper. De nutriënten in het slib eindigen na indampen, met uitzondering van tijdens het indampen verdampt $\mathrm{N}-\mathrm{NH}_{4}$, in het ingedampte slib. De bij het indampen ontstane damp, inclusief een deel van de $\mathrm{N}-\mathrm{NH}_{4}$, wordt na condensatie behandeld door de afvalwaterzuiveringsinstallatie. Ecoson zet het ingedampte MBR-slib af aan een kolencentrale voor bijstook. Het is aannemelijk dat de stikstof die het bevat daar, na oxidatie, in de afgassen eindigt als $\mathrm{NO}_{\mathrm{x}}$. Een deel van de $\mathrm{NO}_{\mathrm{x}}$ wordt daarna mogelijk weer omgezet in stikstofgas $\left(\mathrm{N}_{2}\right)$ door toevoeging van, en reactie met, een ammoniakoplossing om uitstoot van $\mathrm{NO}_{x}$ te verminderen. De overige nutriënten eindigen waarschijnlijk in de vliegas en bodem-as.

De som van de uitgaande stromen als percentage van de ingaande stromen wijkt voor drogestof en fosfaat minimaal $10 \%$ af van $100 \%$. Voor droge stof komt dit hoogstwaarschijnlijk door toename in organische stof (bacteriegroei) in de MBR. Voor fosfaat is de reden van de afwijking onduidelijk. Berekend is dat circa $17 \%$ van de stikstof in het influent van de MBR eindigt in de afgezogen lucht van de MBR die naar de luchtwasser gaat en die grotendeels wordt afgevangen als ammoniumsulfaatoplossing (niet getoond in Tabel 3.26).

Tabel 3.26 Samenstelling van de in- en uitgaande stromen van de humuszuurinstallatie van Ecoson en het berekende scheidingsrendement als percentage van het influent. HZC: humuszuurconcentraat, MBR: membraanbioreactor, HZI: humuszuurinstallatie. Gemiddelde waarden op basis van eigen monitoring door Ecoson. ${ }^{1}$

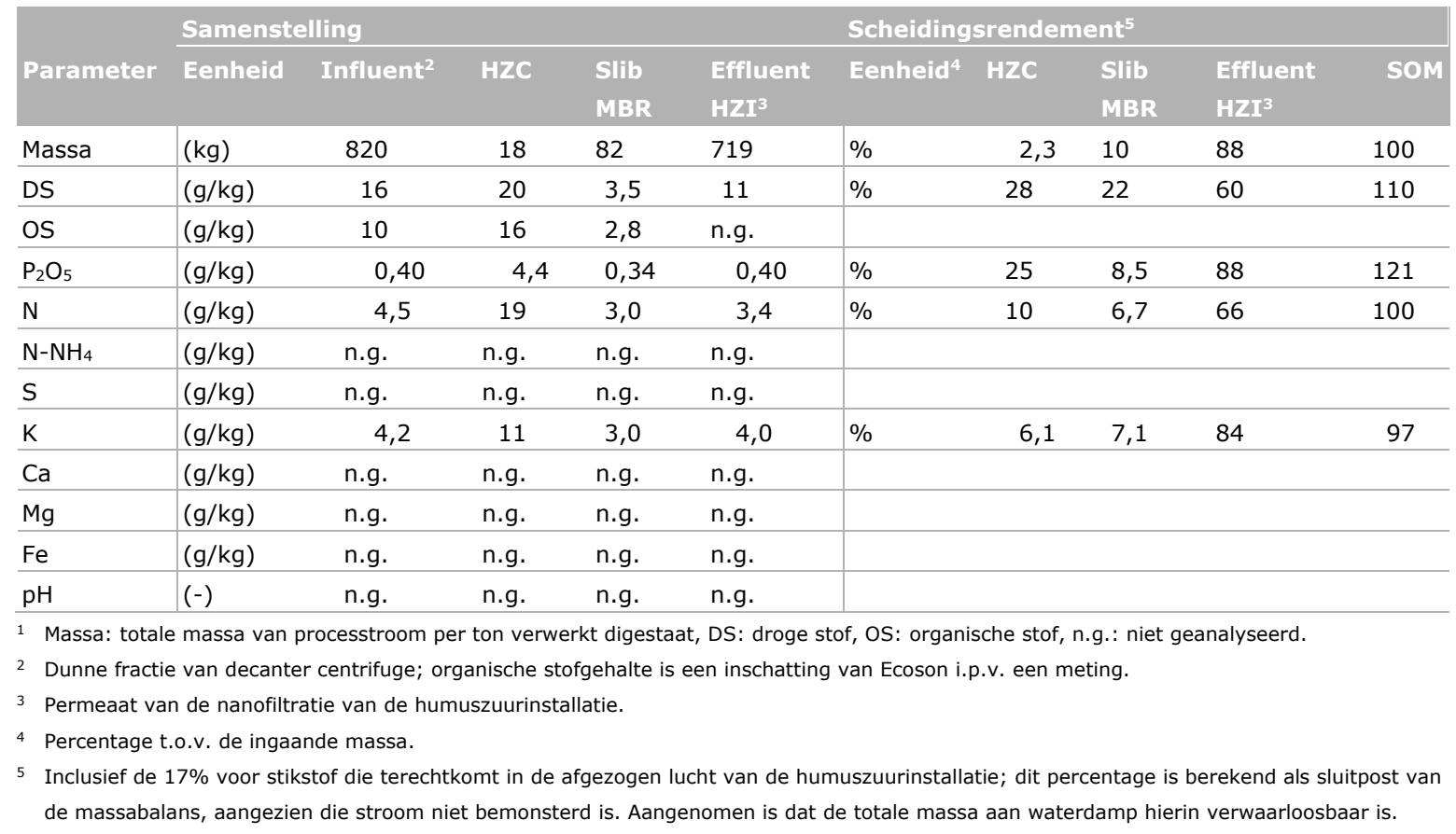




\subsubsection{Band- en schijvendroger en korrelpers}

Tabel 3.27 toont de samenstelling van de in- en uitgaande stromen en de berekende scheidingsrendementen van de band- en schijvendroger en de korrelpers van Ecoson. De geproduceerde mestkorrels hebben een hoog drogestofgehalte van $917 \mathrm{~g} / \mathrm{kg}$ en bestaan voor $73 \%$ uit organische stof. Alle nutriënten uit de ingaande dikke fractie van de decanter centrifuge, met uitzondering van stikstof, komen voor praktisch $100 \%$ in de mestkorrels terecht. Voor stikstof zijn de gehalten in de damp van de band- en schijvendroger en het condensaat van de schijvendroger berekend als sluitpost in de massabalans, aangezien die stromen niet bemonsterd zijn. Vanwege deze rekenmethode kan niks gezegd worden over de aan- of afwezigheid van verliezen van $\mathrm{N}-\mathrm{NH}_{4}$ naar de lucht. Van de ingaande stikstof komt circa $62 \%$ in de mestkorrels en gezamenlijk $38 \%$ terecht in de damp van de band- en schijvendroger en het condensaat van de schijvendroger.

De damp van de band- en schrijvendroger gaat naar een luchtwasser waar de $\mathrm{N}-\mathrm{NH}_{4}$ grotendeels wordt afgevangen als een ammoniumsulfaatoplossing. Het condensaat van de schijvendroger gaat naar de afvalwaterzuiveringsinstallatie. Op basis van een inschatting van Ecoson is aangenomen dat grofweg $70 \%$ van de $\mathrm{N}-\mathrm{NH}_{4}$ uit het condensaat van de schijvendroger naar de waterzuivering gaat en de overige $30 \%$ naar de luchtwasser. Van de stikstof in de ingaande dikke fractie komt dan gezamenlijk circa $26 \%$ terecht bij de luchtwasser.

Tabel 3.27 Samenstelling van de in- en uitgaande stromen van de band- en schijvendroger en korrelpers van Ecoson en het berekende scheidingsrendement als percentage van het influent. Gemiddelde waarden op basis van eigen monitoring door Ecoson. ${ }^{1}$

\begin{tabular}{|c|c|c|c|c|c|c|c|c|c|c|}
\hline \multirow[b]{2}{*}{$\begin{array}{l}\text { Para- } \\
\text { meter }\end{array}$} & \multicolumn{5}{|c|}{ Samenstelling } & \multicolumn{5}{|c|}{ Scheidingsrendement } \\
\hline & Eenheid & Influent ${ }^{2}$ & $\begin{array}{l}\text { Mest- } \\
\text { korrels }\end{array}$ & $\begin{array}{l}\text { Damp } \\
\text { band- } \\
\text { droger }{ }^{3}\end{array}$ & $\begin{array}{l}\text { Conden- } \\
\text { saat } \\
\text { schijven- } \\
\text { droger }{ }^{3}\end{array}$ & Eenheid ${ }^{4}$ & $\begin{array}{l}\text { Mest- } \\
\text { korrels }\end{array}$ & $\begin{array}{l}\text { Damp } \\
\text { band- } \\
\text { droger }\end{array}$ & $\begin{array}{l}\text { Conden- } \\
\text { saat } \\
\text { schijven- } \\
\text { droger }\end{array}$ & SOM \\
\hline Massa & $(\mathrm{kg})$ & 204 & 65 & 77 & 62 & $\%$ & 32 & 38 & 30 & 100 \\
\hline DS & $(\mathrm{g} / \mathrm{kg})$ & 292 & 917 & 0,0 & 0,0 & $\%$ & 100 & 0,0 & 0,0 & 100 \\
\hline OS & $(\mathrm{g} / \mathrm{kg})$ & 232 & 727 & 0,0 & 0,0 & $\%$ & 100 & 0,0 & 0,0 & 100 \\
\hline $\mathrm{P}_{2} \mathrm{O}_{5}$ & $(\mathrm{~g} / \mathrm{kg})$ & 19 & 61 & 0,0 & 0,0 & $\%$ & 100 & 0,0 & 0,0 & 100 \\
\hline $\mathrm{N}$ & $(\mathrm{g} / \mathrm{kg})$ & 14 & 27 & 7,6 & 7,6 & $\%$ & 62 & 21 & 17 & 100 \\
\hline $\mathrm{N}-\mathrm{NH}_{4}$ & $(\mathrm{~g} / \mathrm{kg})$ & n.g. & n.g. & n.g. & n.g. & & & & & \\
\hline $\mathrm{S}$ & $(\mathrm{g} / \mathrm{kg})$ & n.g. & n.g. & n.g. & n.g. & & & & & \\
\hline $\mathrm{K}$ & $(\mathrm{g} / \mathrm{kg})$ & 5,5 & 17 & 0,0 & 0,0 & $\%$ & 101 & 0,0 & 0,0 & 101 \\
\hline $\mathrm{Ca}$ & $(\mathrm{g} / \mathrm{kg})$ & n.g. & n.g. & n.g. & n.g. & & & & & \\
\hline $\mathrm{Mg}$ & $(\mathrm{g} / \mathrm{kg})$ & n.g. & n.g. & n.g. & n.g. & & & & & \\
\hline $\mathrm{Fe}$ & $(\mathrm{g} / \mathrm{kg})$ & n.g. & n.g. & n.g. & n.g. & & & & & \\
\hline $\mathrm{pH}$ & $(-)$ & n.g. & n.g. & n.g. & n.g. & & & & & \\
\hline \multicolumn{11}{|c|}{1 Massa: totale massa van processtroom per ton verwerkt digestaat, DS: droge stof, OS: organische stof, n.g.: niet geanalyseerd. } \\
\hline \multicolumn{11}{|c|}{2 Dikke fractie van decanter centrifuge; stikstofgehalte is berekend (als verschilberekening in de massabalans). } \\
\hline \multicolumn{11}{|c|}{3 Stikstofgehalte is berekend (als verschilberekening in de massabalans). } \\
\hline \multicolumn{11}{|c|}{4 Percentage t.o.v. de ingaande massa. } \\
\hline
\end{tabular}

\subsubsection{Massabalans}

Figuur 3.16 en Figuur 3.17 tonen de stroomdiagrammen voor de totale massa van het verwerkte digestaat en de parameters stikstof, fosfaat en kalium. 


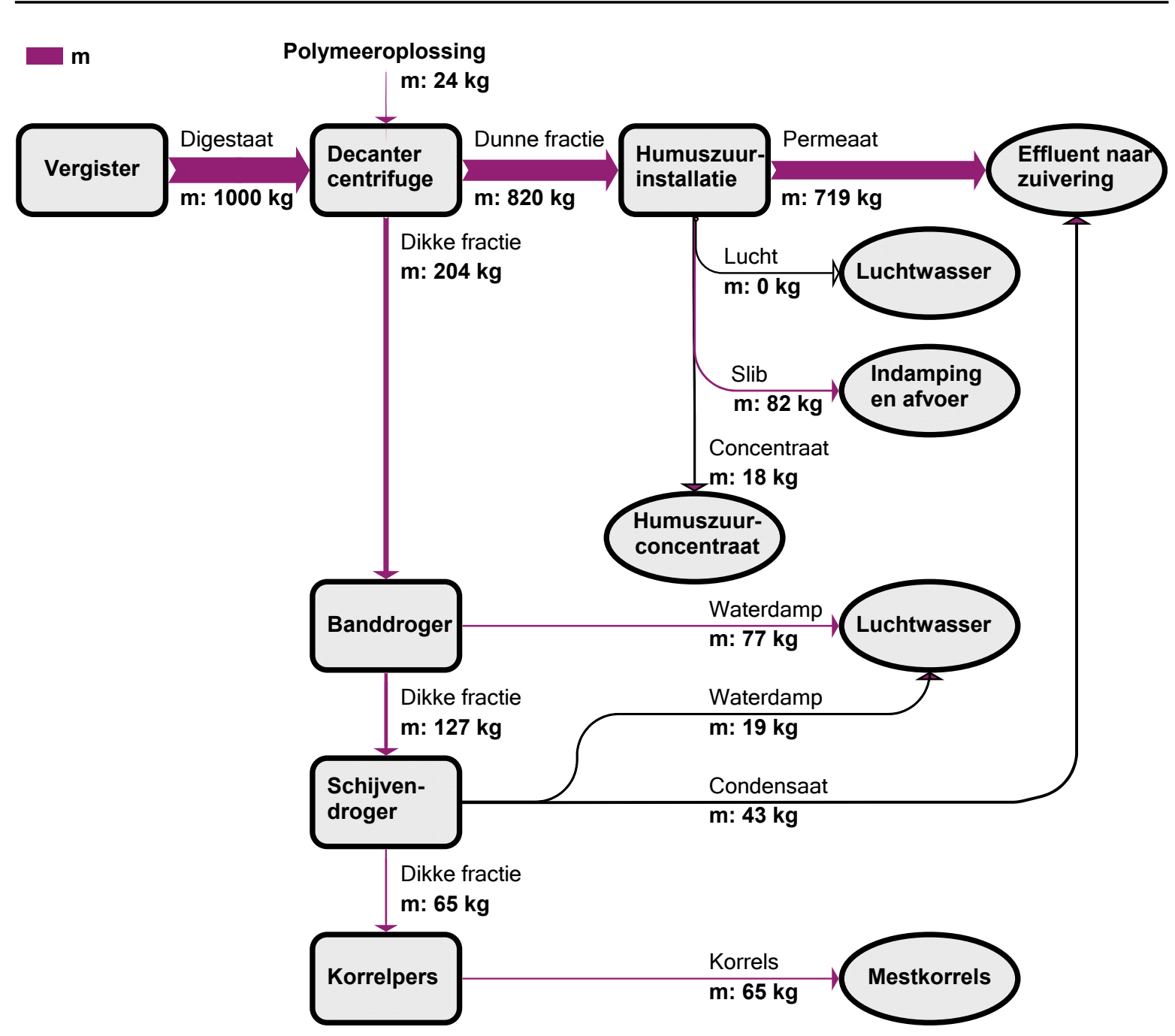

Figuur 3.16 Sankey-diagram van de totale massa $(\mathrm{m})$ per $1000 \mathrm{~kg}$ verwerkt digestaat van de digestaatverwerkingsinstallatie van Ecoson op basis van door Ecoson berekende debieten inclusief uitbalancering, daarom is de som van de uitgaande stromen exact gelijk aan $1000 \mathrm{~kg}$.

De totale massa toegevoegde chemie, $24 \mathrm{~kg}$ per ton verwerkt digestaat, is beperkt. Elke $1000 \mathrm{~kg}$ verwerkt digestaat resulteert in $65 \mathrm{~kg}$ mestkorrels, $18 \mathrm{~kg}$ humuszuurconcentraat, $82 \mathrm{~kg}$ slib van de membraanbioreactor, $86 \mathrm{~kg}$ over een luchtwasser uitgeblazen waterdamp en gezamenlijk $796 \mathrm{~kg}$ aan permeaat en condensaat dat naar de afvalwaterzuivering gaat en daarna op het oppervlaktewater wordt geloosd. Als wordt aangenomen dat het drogestofgehalte van het MBR-slib na indampen is gestegen van 3,5 naar 90\%, dan blijft circa $3 \mathrm{~kg}$ te transporteren ingedikt slib over. Bovenstaande bij elkaar genomen, resulteert tezamen in $86 \mathrm{~kg}$ eindproducten uit één ton digestaat. De per as te transporteren massa is dus met $91 \%$ verminderd ten opzichte van het ingaande digestaat. De hoeveelheid geproduceerde ammoniumsulfaatoplossing en de hoeveelheid van het aan de digestaatverwerking toe te schrijven geproduceerde zuiveringsslib van de afvalwaterzuiveringsinstallatie zijn hierin echter niet meegenomen omdat die niet bekend zijn. 


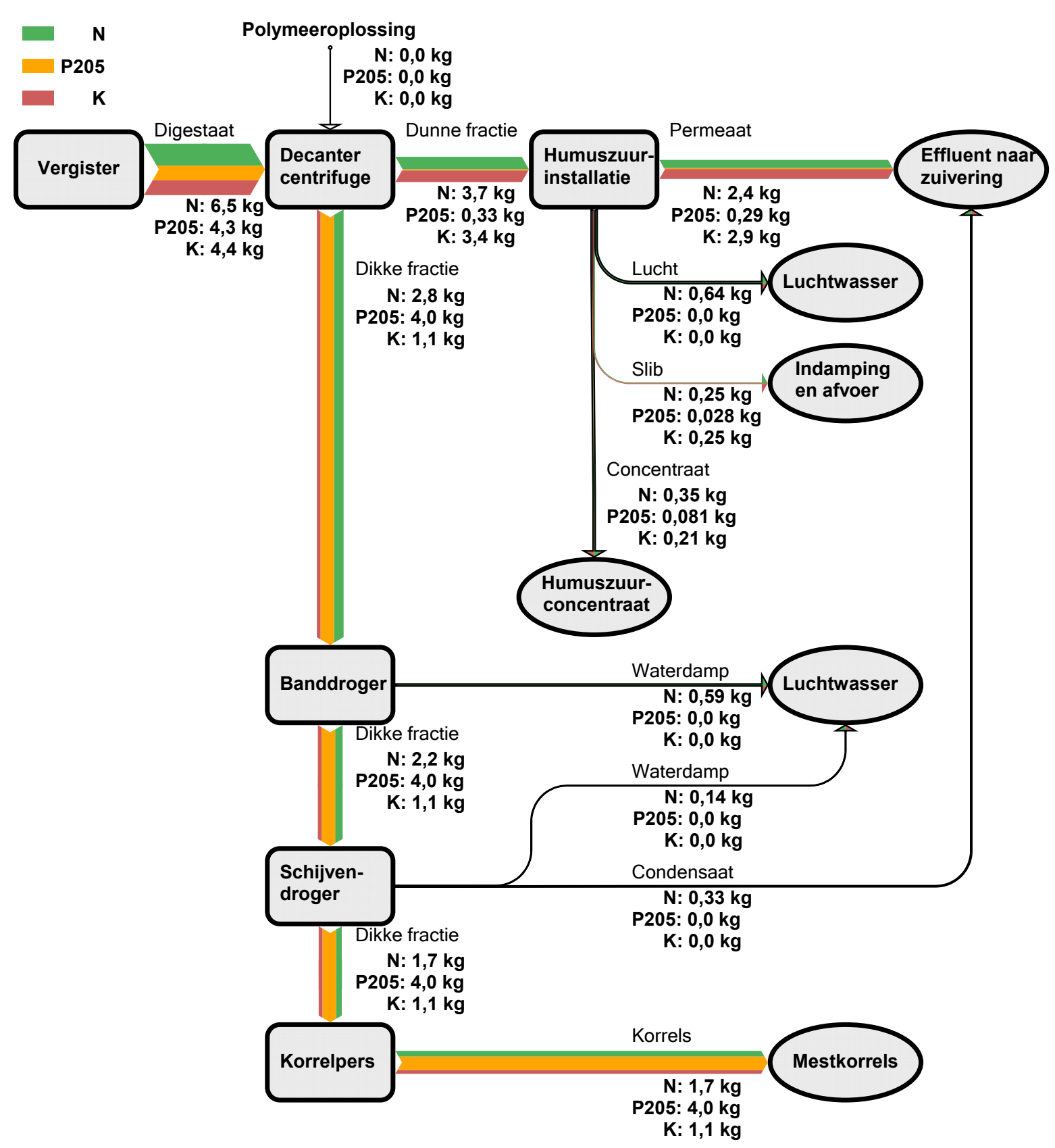

Figuur 3.17 Sankey-diagram van de massa totaalstikstof $(N)$, totaalfosfaat $\left(\mathrm{P}_{2} \mathrm{O}_{5}\right)$ en totaalkalium (K) per $1000 \mathrm{~kg}$ verwerkt digestaat van de digestaatverwerkingsinstallatie van Ecoson op basis van door Ecoson berekende debieten, vermenigvuldigd met door Ecoson gemeten concentraties.

Uit Figuur 3.17 volgt dat van de ingaande stikstof, fosfaat en kalium respectievelijk $27 \%$, $92 \%$ en $25 \%$ in de mestkorrels terechtkomt. Bij de afvalwaterzuivering eindigt respectievelijk $43 \%, 7 \%$ en $64 \%$ van de ingaande stikstof, fosfaat en kalium. De afgezogen lucht van de HZI en de waterdamp van de banddroger en schijvendroger bevat gezamenlijk circa $21 \%$ van de ingaande stikstof; dit zal grotendeels door de luchtwassers worden afgevangen als ammoniumsulfaatoplossing. Na indampen van het slib van de MBR blijft een ingedikt slib over dat $6 \%$ van de ingaande kalium bevat.

Tabel 3.28 toont de berekende massabalans per $1000 \mathrm{~kg}$ verwerkt digestaat van de digestaatverwerkingsinstallatie van Ecoson. Het totaal aan eindproducten als percentage van ingaand digestaat plus toegevoegde chemie en bijbehorend oploswater ligt voor alle componenten rond de $100 \%$. 
Tabel 3.28 Massabalans van de digestaatverwerkingsinstallatie van Ecoson in $\mathrm{kg}$ per ton ingaand digestaat. HZC: humuszuurconcentraat, MBR: membraanbioreactor, HZI: humuszuurinstallatie. Gemiddelde waarden op basis van eigen monitoring door Ecoson. ${ }^{1}$

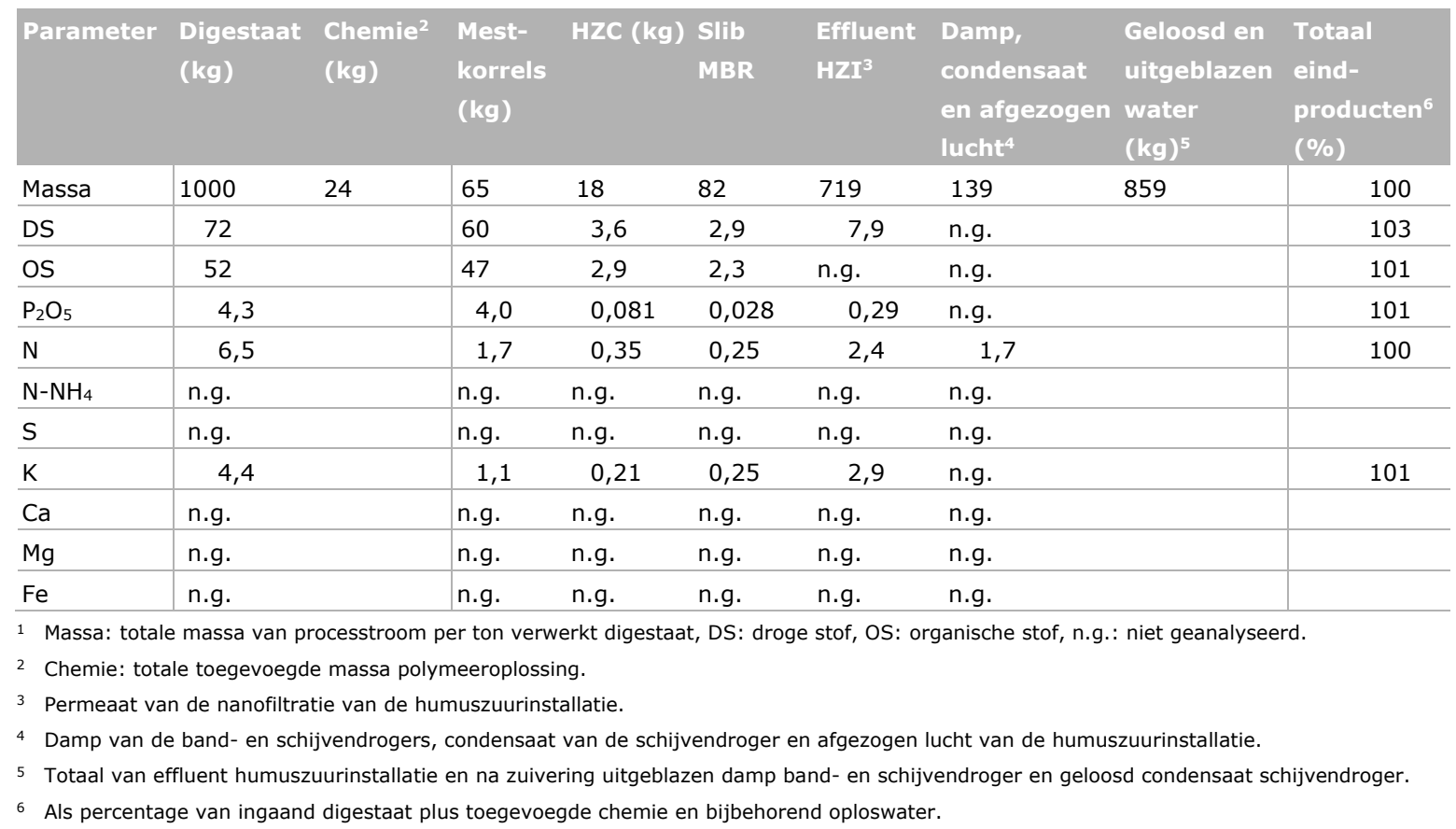

\subsubsection{Chemie- en energieverbruik}

Per ton verwerkt digestaat wordt voor de decanter centrifuge $24 \mathrm{~kg}$ polymeeroplossing toegevoegd. Het totale elektriciteitsverbruik van de digestaatverwerkingsinstallatie, inclusief de daaraan voorafgaande vergisters, was circa 7 GWh voor het jaar 2020. Daarvan werd door de vergisters, de decanter centrifuge en de band- en schijvendroger circa 3,9 GWh gezamenlijk verbruikt. Circa 2,6 GWh van de $7 \mathrm{GWh}$ werd verbruikt door de HZI. Het elektriciteitsverbruik van de afvalwaterzuiveringsinstallatie dat toe te schijven is aan de digestaatverwerking van Ecoson is door Ecoson berekend op circa 0,5 GWh per jaar. Daarnaast verbruiken de band- en schijvendroger gezamenlijk circa $14 \mathrm{GWh}$ aan thermische energie per jaar.

\subsection{Twence}

\subsubsection{Algemene beschrijving}

TWENCE is een publiek bedrijf in de regio Twente waar afval- en biomassastromen worden omgezet in energie en grondstoffen. Huishoudelijk restafval, reststromen van afvalrecycling en restafval van bedrijven worden energetisch benut, waarna de bodemassen na terugwinning van metalen worden opgewerkt tot bouwmateriaal voor wegen. Biomassa ( $\mathrm{gft}$ en reststromen van de levensmiddelenindustrie) wordt vergist en gecomposteerd. Afvalhout wordt ingezet als brandstof in een biomassacentrale. De door Twence geproduceerde elektriciteit wordt geleverd aan huishoudens. De geproduceerde warmte wordt deels (als warm water) geleverd aan het stadsverwarmingsnet in Enschede en deels (als stoom) aan zoutproducent Nobian. Op de locatie Elhorst Vloedbelt in Zenderen bouwt Twence een mestverwerkingsinstallatie om veehouders in Twente die een fosfaatoverschot hebben, de mogelijkheid te bieden hun mest te laten verwerken. Het tweede doel is uit die mest hernieuwbare energie op te wekken en de waardevolle componenten die het bevat te benutten als organische fosfaatmeststof, ammoniakwater, kaliummeststof en gezuiverd water. De bouw ervan is begin 2021 gestart. De locatie is een stortplaats voor restafval waar nog stortgas uit vrijkomt dat benut wordt voor de productie van hernieuwbare energie. Ondertussen is $80 \%$ van de mestverwerkingscapaciteit van de nieuwe installatie gecontracteerd in contracten voor drie jaar. 
Volgens Twence bespaart de installatie veel transportkilometers en kunnen landbouwbedrijven hun methaan- en ammoniakemissies verminderen doordat die bedrijven hun verse mest aan Twence kunnen leveren.

De installatie heeft een verwerkingscapaciteit van 250 kton varkensdrijfmest per jaar. De mest wordt vergist waarbij op massabasis maximaal 5\% co-producten zullen worden bijgemengd om de koolstoftot-stikstofverhouding te optimaliseren. Het geproduceerde biogas wordt door middel van verwijdering van $\mathrm{CO}_{2}$ en $\mathrm{H}_{2} \mathrm{~S}$ opgewerkt tot bijna 5 miljoen $\mathrm{m}^{3}$ groengas per jaar ( 88 vol.- $\% \mathrm{CH}_{4}$ ), dat via het gasnet wordt afgezet. Deze hoeveelheid staat gelijk aan het jaarlijkse aardgasverbruik van circa 3.000 huishoudens. De verwijdering van $\mathrm{H}_{2} \mathrm{~S}$ uit het biogas gebeurt met een actiefkoolfilter. De vergiste mest wordt via een flotatiescheider en zeefbandpers gescheiden in een dikke en een dunne fractie. Op de flotatiescheider wordt alleen polymeer gedoseerd, geen ijzersulfaat. De mest wordt tijdens de vergisting gehygiëniseerd en de dikke fractie, die naar verwachting een drogestofgehalte zal hebben van $30 \%$, is daardoor geschikt voor export. De nutriënten in de dunne fractie worden door een RO geconcentreerd en daarna door een indamper gescheiden in ammoniakwater en een vloeibare kaliummeststof. Het ammoniakwater bestaat voor ruim $20 \%$ uit ammoniak (circa 5.000 ton ammoniakwater per jaar). Het gaat volledig worden benut voor de verwijdering van $\mathrm{NO}_{x}$ uit de rookgassen van de afvalenergiecentrale in Hengelo. De kaliummeststof zal in de regionale landbouw worden afgezet voor kaliumbehoeftige gewassen. Een polisher en ionenwisselaar zuiveren het permeaat van de RO, zodat het aan de eisen voor lozen op het oppervlaktewater voldoet en door boeren kan worden gebruikt voor o.a. beregening.

\subsection{Synthese massabalansen}

Het berekenen van massabalansen van mest- en digestaatverwerkers gaat gepaard met een zekere foutmarge veroorzaakt door o.a. temporele variatie in de samenstelling van processtromen, nietrepresentatieve monstername van stromen die bezinkbare deeltjes bevatten en onnauwkeurigheden in laboratoriumanalyses. Als debietmeters gebruikt worden, speelt ook de foutmarge in het gemeten debiet mee. Met deze onnauwkeurigheden dient rekening gehouden te worden bij controle van de mestboekhouding van verwerkers op basis van een massabalans. In Vlaanderen is recentelijk besloten om debietmeters op mestverwerkingsinstallaties verplicht te stellen met ingang van 1 januari 2022 om mestfraude te bestrijden. Bij een dergelijke aanpak is het aan te bevelen om vooraf te berekenen met welke nauwkeurigheid een massabalans kan worden opgesteld. Afwijkingen van $10 \%$ of meer komen in de hier berekende massabalansen regelmatig voor bij individuele scheidingsapparaten. Het is niet mogelijk om de grootte van ammoniakverliezen vast te stellen uit de berekende massabalansen, omdat ook voor niet-vluchtige componenten afwijkingen van een vergelijkbare ordegrootte voorkomen. Daarvoor is de gebruikte methode voor het opstellen van de massabalansen niet nauwkeurig genoeg. 
Tabel 3.29 Samenvatting massabalansen, transportvoordeel en andere indicatoren voor de geëvalueerde verwerkingsinstallaties voor mest of co-vergiste mest (digestaat).

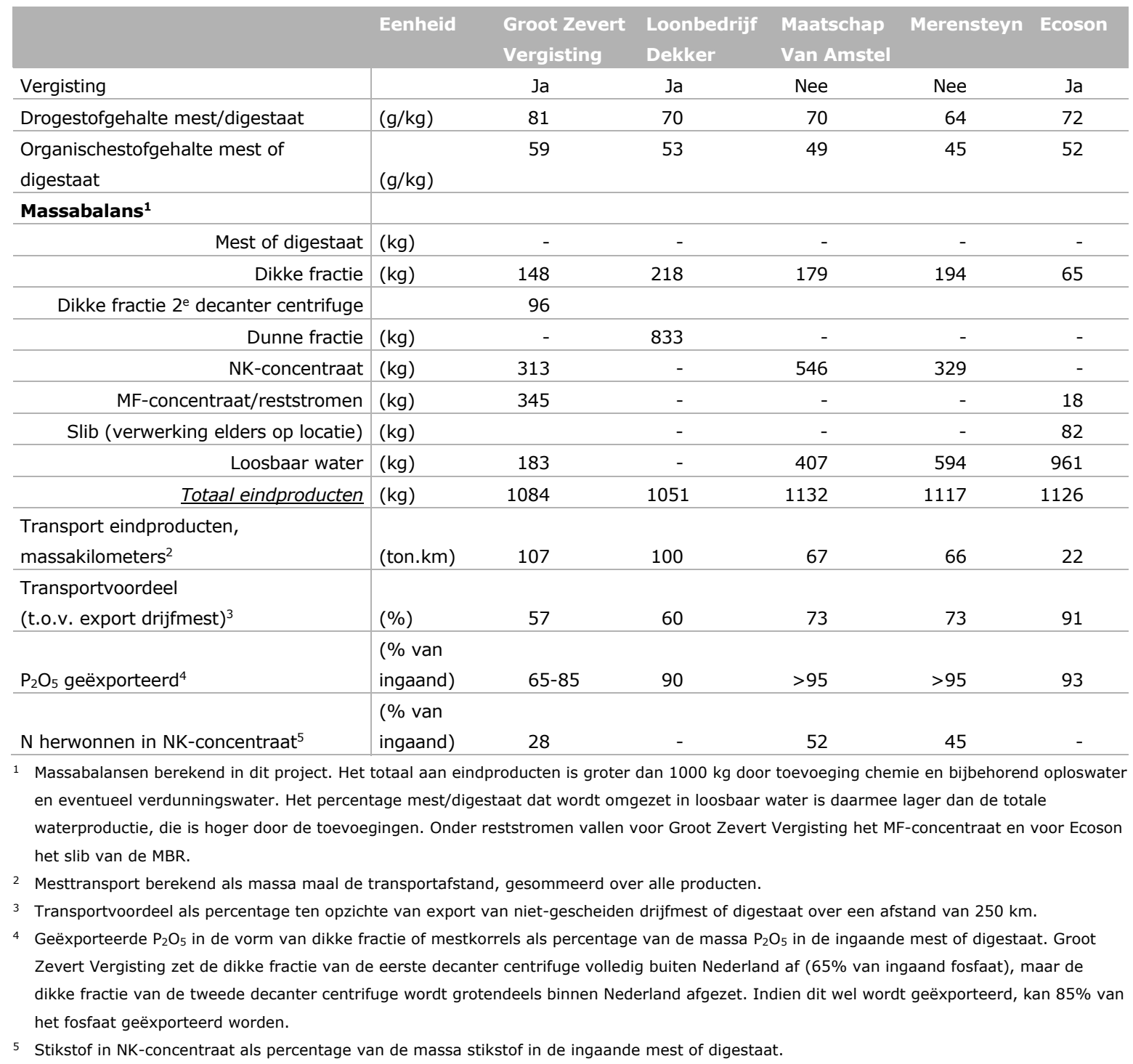

Tabel 3.29 geeft een overzicht van de massabalansen per verwerker en het gerealiseerde voordeel in termen van mesttransport, uitgedrukt in massakilometers. Bij het vergelijken van de verwerkingsinstallaties moet rekening gehouden worden met verschillen in de samenstelling van de aanvoer. Het digestaat van GZV kenmerkt zich door hogere gehalten aan droge stof, stikstof en fosfaat ten opzichte van de ingaande stroom bij de andere verwerkers door het mee-vergisten van een relatief grote hoeveelheid co-producten. Geschat wordt dat $76 \%$ van de biogasproductie afkomstig is uit de co-producten. Ook Dekker past co-vergisting toe, echter de bijdrage van co-producten is daar lager dan bij GZV. Bij Ecoson worden geen co-producten vergist, maar wel ongeboren mest, waardoor het drogestofgehalte van het digestaat hoger is dan verwacht mag worden bij vergisting van louter drijfmest. Verschillen in de samenstelling van de ingaande stroom kunnen van invloed zijn op scheidingsrendementen van de verwerkingsinstallaties.

Mestverwerking heeft als doel om de kosten voor de afzet van mest te verlagen en dit kan door opconcentreren van fosfaat in dikke fractie, verwerking van mest tot producten die regio afzetbaar zijn en/of productie van loosbaar water. De waterproductie per ton digestaat is lager bij GZV ten opzichte van Merensteyn en Van Amstel. Dit komt omdat bij GZV een groot aandeel van het digestaat wordt omgezet in MF-concentraat. Vanuit bedrijfseconomisch oogpunt is niet zozeer de waterproductie, maar de massa aan eindproducten maal de transportafstand van belang. Immers, indien een meststof lokaal afgezet kan worden, heeft verder op-concentreren geen meerwaarde. Bij GZV wordt een voordeel van $57 \%$ behaald op de massakilometers per ton ingaande digestaat ten opzichte van afzet van het digestaat over een afstand van $250 \mathrm{~km}$ (Tabel 3.29). Bij Merensteyn en Van Amstel is het 
transportvoordeel in massakilometers circa $73 \%$ ten opzichte van export van drijfmest. Scheiding in dik/dun bij Dekker geeft een voordeel van $60 \%$ ten opzichte van export van drijfmest, omdat de dunne fractie lokaal wordt afgezet. Het verwerkingsproces van Ecoson geeft de hoogste besparing op mesttransporten, omdat hierbij alleen de gekorrelde dikke fractie wordt afgezet.

Op alle verwerkingsinstallaties wordt eerst een dik-dunscheiding uitgevoerd met een zeefbandpers of decanter centrifuge. Er zijn verschillen in het gebruik van chemie en de scheidingsrendementen. Alle verwerkers doseren polymeer; de hoogte van het polymeerverbruik is onderling niet vergelijkbaar door gebruik van verschillende producten. De zeefbandpersen van Merensteyn en Van Amstel scheiden met toevoeging van $\mathrm{Fe}_{2}\left(\mathrm{SO}_{4}\right)_{3}$ en polymeer circa 95-99\% van het ingaande fosfaat af naar de dikke fractie. Het ijzerzout zorgt voor een laag fosfaatgehalte $(<0,15 \mathrm{~g} / \mathrm{kg})$ in het influent van de ROinstallatie waardoor zoutaanslag op de RO-membranen wordt tegengegaan en een NK-concentraat met een laag fosfaatgehalte wordt geproduceerd. Een nadeel van het gebruik van ijzersulfaat is dat het leidt tot verhoogde ijzergehalten in de dikke fractie (lagere gewasbeschikbaarheid fosfaat) en verhoogde zwavelgehalten in het NK-concentraat. Dekker gebruikt geen ijzerzout, maar wel polymeer en realiseert daarmee een scheidingsrendement van $90 \%$ voor fosfaat op de zeefbandpers. Het fosfaatgehalte in de dunne fractie is voldoende laag voor afzet naar de nabijgelegen akkerbouw en wordt niet opgewerkt tot NK-concentraat.

Ecoson en GZV maken gebruik van decanter centrifuges voor de eerste scheidingsstap. Ecoson scheidt daarbij nagenoeg alle fosfaat af in de dikke fractie waarbij polymeer wordt gedoseerd. GZV scheidt het digestaat middels twee in serie geschakelde decanter centrifuges. De eerste decanter centrifuge scheidt $63 \%$ van het fosfaat af naar de dikke fractie zonder toevoeging van polymeer of ijzerzout, waardoor de dikke fractie geschikt is voor opwerking tot veenvervanger en verhandeling onder de nieuwe EU Meststoffenwet (zie hoofdstuk 5). In plaats van ijzerzout wordt $\mathrm{MgCl}_{2}$ gedoseerd om het fosfaatgehalte in de dunne fractie te verlagen. De dunne fractie van de eerste decanter centrifuge wordt - na toevoeging van polymeer - behandeld op de tweede decanter centrifuge en daarna op de MF waarbij het overige deel van het fosfaat wordt afgevangen in verpompbare concentraatstromen en dit wordt grotendeels binnen Nederland afgezet naar akkerbouwers (onder de gebruiksnorm dierlijke mest). De omvang van deze reststromen is echter groot (circa $440 \mathrm{~kg}$ per ton digestaat) en mogelijk is dit deels een gevolg van de co-vergistingsproducten waardoor het aandeel fijne organische stof hoger is dan bij verwerking van (mono-vergiste) drijfmest. Deze hypothese kon echter niet binnen dit project getoetst worden. Door afzet van deze reststromen binnen de Nederlandse landbouw telt het fosfaat niet mee voor de fosfaatverwerkingsplicht, maar vanwege de lage waarde van VVO's in 2020 (zie hoofdstuk 6) is er bij GZV op dit moment ook geen economisch motief om te streven naar een hoog aandeel te exporteren fosfaat. Bij de andere verwerkers wordt wel minimaal $95 \%$ van het fosfaat uit ingaande mest of digestaat middels export buiten de Nederlandse landbouw geplaatst.

Er zijn drie verwerkers waarbij de dunne fractie, na voorbehandeling op een DAF of MF, wordt opgeconcentreerd tot een NK-concentraat. Er zijn verschillen in de configuratie van de RO-installaties en de hoogte van de zwavelzuurdosering. Van Amstel bedrijft een enkele RO-installatie waarmee de dunne fractie een factor 1,8 wordt op-geconcentreerd. Bij Merensteyn zijn twee in serie geschakelde RO's aanwezig, waardoor een concentratiefactor van 3,3 wordt bereikt en een hoger aandeel loosbaar water wordt geproduceerd. Van Amstel concentreert het NK-concentraat bewust minder ver op, zodat bijmengen van ammoniumsulfaatoplossing aantrekkelijk blijft zonder risico's op gewasverbranding door te hoge ammoniumconcentraties. Ammoniumsulfaat wordt bijgemengd ter verhoging van de verhouding N/K. Bij GZV wordt het influent van de RO-installaties een factor 2 op-geconcentreerd door twee aaneengeschakelde RO-installaties. De configuratie wijkt af van die op Merensteyn en heeft als doel een lager zuurverbruik te realiseren. Bij GZV behandelt de tweede RO-installatie het permeaat van de eerste RO-installatie. Op de eerste RO-installatie wordt nauwelijks zuur gedoseerd, waardoor een deel van het ammonium in het permeaat komt. De echte aanzuring vindt pas plaats op dit permeaat (influent van de tweede RO), wat relatief efficiënt is door de lagere pH-buffercapaciteit van dit permeaat ten opzichte van het influent van de eerste RO. Het concentraat van de tweede RO wordt vervolgens teruggevoerd naar de eerste RO, en het concentraat van de eerste RO is het NKconcentraat. 
Op RO-installaties wordt zwavelzuur gedoseerd om te voorkomen dat ammonium het membraan passeert. Het zwavelzuurverbruik, uitgedrukt in $\mathrm{kg} \mathrm{S}$ per ton ingaande mest of digestaat, bedraagt $0,43 \mathrm{~kg}, 0,73 \mathrm{~kg}$ en 1,3 kg voor respectievelijk Van Amstel, GZV en Merensteyn. Wanneer de zwavelzuurdosering wordt uitgedrukt per ton influent van de RO-installatie, is het verbruik op GZV en Merensteyn nagenoeg gelijk (respectievelijk 1,1 versus $1,3 \mathrm{~kg} \mathrm{~S}$ per ton influent van de RO), wat betekent dat er geen duidelijk voordeel is in zuurverbruik ten opzichte van installaties waar drijfmest wordt verwerkt. Het is echter aannemelijk dat vergisting leidt tot een hogere pH-buffercapaciteit (hogere gehalten aan bicarbonaat en ammonium) van het RO-influent op GZV ten opzichte van het RO-influent op basis van drijfmest (Van Amstel en Merensteyn) en dat gepaard met een hoger zuurverbruik. Naast zwavelzuur draagt ook het gebruik van ijzersulfaat bij aan verhoogde zwavelgehalten in NK-concentraat. Van Amstel en Merensteyn voegen per ton ingaande mest respectievelijk 0,62 en 0,90 kg S toe als $\mathrm{Fe}_{2}\left(\mathrm{SO}_{4}\right)_{3}$-oplossing, terwijl op GZV geen ijzersulfaat wordt gedoseerd. Dit resulteert in een relatief laag zwavelgehalte in het NK-concentraat $(1,5 \mathrm{~g} \mathrm{~S} / \mathrm{kg}) \mathrm{van}$ GZV ten opzichte van Van Amstel $(2,4 \mathrm{~g} \mathrm{~S} / \mathrm{kg})$ en Merensteyn $(5,5 \mathrm{~g} \mathrm{~S} / \mathrm{kg})$.

Een aandachtspunt bij verwerking van mest en digestaat is de vorming van $\mathrm{H}_{2} \mathrm{~S}$, wat zich vormt bij vergisting of opslag van mest. Dit speelt bij GZV waar geen ijzer wordt gedoseerd in de vergister om $\mathrm{H} 2 \mathrm{~S}$ te beheersen (het biogas wordt ontzwaveld). Hier zijn hoge zwavelgehalten waargenomen in het permeaat na de RO en dit vraagt om nader onderzoek naar de analysemethoden en de herkomst van dit zwavel. Het advies luidt om vanuit veiligheidsoogpunt toch ijzerzouten te doseren om emissies van $\mathrm{H}_{2} \mathrm{~S}$ te beheersen. Het loosbare water voldoet wel aan de gestelde criteria. Bij Van Amstel en Merensteyn is geen zwavel aangetroffen in het permeaat van de RO-installaties en zijn risico's op $\mathrm{H}_{2} \mathrm{~S}-$ emissies ook lager, omdat geen vergisting wordt toegepast en omdat ijzer wordt gedoseerd, wat effectief is in het neerslaan van sulfiden. Een ander aandachtspunt vanuit bedrijfsvoering is dat er zeer grote verschillen zijn in de frequentie waarmee ionenwisselaars geregenereerd worden en het is onduidelijk of deze verschillen volledig zijn toe te schrijven aan de verschillen in $\mathrm{NH}_{4}$-concentratie in het te lozen water.

Ecoson verwerkt de dikke fractie door drogen en persen tot een mestkorrel en verwijdert een groot deel van de stikstof in de dunne fractie en de damp van de drogers met een Anammoxafvalwaterzuivering. Slib van de MBR wordt op het eigen bedrijf verwerkt. De per as te transporteren massa wordt hierdoor met $91 \%$ verminderd ten opzichte van het ingaande digestaat. Ecoson maakt hierbij gebruik van restwarmte afkomstig van andere bedrijfsactiviteiten op de locatie. De waterzuivering werd te veel belast met humuszuren, die niet worden afgebroken in de waterzuivering en zodoende bijdragen aan het opgeloste organische stofgehalte in het effluent. Daarom wordt de dunne fractie nu behandeld door een beluchte biologische reactor en een MBR voor afbraak van organische stof gevolgd door een NF die humuszuren afvangt. Het permeaat van de NF is qua samenstelling geschikt voor opwerking tot NK-concentraat. Omdat de locatie al een eigen waterzuivering heeft voor andere bedrijfsactiviteiten en omdat opslag en afzet van NK-concentraat extra kosten geeft, is het kostentechnisch voordeliger om de stikstof biologisch om te zetten naar stikstofgas $\left(\mathrm{N}_{2}\right)$.

Voor mestverwerker Twence is geen massabalans opgesteld, omdat deze installatie nog in aanbouw is. De installatie zal mest vergisten en verwerken tot dikke fractie, ammoniakwater, een kaliummeststof en loosbaar water. Ook Twence verwacht hierbij een polymeer te gaan toevoegen. Stikstof wordt niet teruggebracht naar de landbouw, maar het ammoniakwater wordt benut in de rookgasreiniging van een afvalverbrander waarmee het synthetisch ammoniakwater vervangt. Afzet buiten de landbouw heeft als voordeel dat hiermee wordt bijgedragen aan het verminderen van ammoniakemissies die ontstaan bij aanwending van meststoffen uit dierlijke mest. Een mogelijk nadeel is de beperkte afzetmogelijkheden voor een kaliumrijk concentraat.

GZV heeft in 2020 het RePeat-systeem in gebruik genomen waarmee de dikke fractie van digestaat door middel van zwavelzuurdosering en twee schroefpersen wordt gescheiden in een vloeistof met opgelost fosfaat en een bodemverbeteraar. De scheidingsrendementen voor de extractie van fosfaat uit de ingaande dikke fractie en voor de terugwinning van fosfaat in de fosfaatprecipitatietank zijn conform verwachtingen, de ontwatering van het fosfaatslib (fosfaatprecipitaat) is echter een aandachtspunt. Door toevoeging van kalkmelk precipiteert het opgeloste fosfaat in een fosfaatslib, wat 
wordt afgescheiden door bezinking. Het effluent van de fosfaatbezinker bevat nauwelijks fosfaat $(0,2 \mathrm{~g} / \mathrm{kg})$ en is geschikt voor hergebruik in het proces. Verbeterpunt is de ontwatering van het fosfaatslib, wat tot op heden gewonnen wordt met een drogestofgehalte van circa $20 \%$. Door dosering van magnesiumhydroxide i.p.v. kalkmelk is de ontwatering te verbeteren. Aandachtspunt is de vorming van $\mathrm{H}_{2} \mathrm{~S}$, wat beheersbaar is door extra afzuigers en continue beluchting van de tanks waarin mogelijk $\mathrm{H}_{2} \mathrm{~S}$ wordt gevormd. Ander aandachtspunt is het hoge chemieverbruik. Aanbevolen wordt het business model te veranderen. Productie van een fosfaatarme bodemverbeteraar geeft geen positieve business case door het hoge chemieverbruik om dit te realiseren en het hoge zwavelgehalte in het eindproduct. Wel kansrijk is de productie van vezels voor o.a. potgrondindustrie en waarvoor slechts een deel van het fosfaat verwijderd hoeft te worden waardoor minder chemie nodig is.

\subsection{Conclusies}

- Er zijn grote verschillen in de manier van mestverwerking tussen de deelnemende bedrijven. Mestverwerkingsprocessen zijn aangepast aan de locatie- en regio-specifieke omstandigheden, zoals beschikbaarheid van restwarmte en mogelijkheden tot afzet van mestproducten in de regio, hetgeen afhankelijk is van het landgebruik en de concurrentie met onbewerkte mest.

- De huidige mestverwerking in Nederland is ontstaan als oplossing voor het fosfaatoverschot. Hiertoe wordt fosfaat afgescheiden in een dikke fractie welke na hygiënisatie wordt geëxporteerd. Voor de scheiding wordt polymeer en, bij een aantal verwerkers, ook ijzersulfaat gedoseerd. Alleen GZV produceert een dikke fractie vrij van polymeer en ijzer, waardoor deze geschikt is voor opwerking tot veenvervanger of verhandeling onder de nieuwe EU-meststoffenwetgeving. Mede hierdoor is het scheidingsrendement op de eerste decanter centrifuge bij GZV laag ten opzichte van het scheidingsrendement voor dik-dunscheiding bij de andere verwerkers. Ook verschillen in het ingangsmateriaal (drijfmest versus co-vergiste mest) speelt hierin waarschijnlijk een rol, dit is echter niet onderzocht binnen dit project.

- Alle verwerkers voegen ergens in het proces polymeer toe om de afscheiding van fijne deeltjes te verbeteren. De doseringen daarvan zijn niet te vergelijken, omdat de verwerkers onderling verschillende polymeren gebruiken. Voor de verwerkers die een NK-concentraat produceren, zijn er grote verschillen in de dosering van zwavelzuur, ijzersulfaat en/of magnesiumchloride. Dit leidt tot verschillen in het zwavelgehalte van het NK-concentraat, wat varieert van 1,4 tot 5,4 g S/kg.

- Op alle mestverwerkingsinstallaties wordt een transportvoordeel gerealiseerd ten opzichte van export van niet-gescheiden drijfmest of digestaat. Een transportvoordeel ontstaan door afzet van de producten in de regio en/of productie van loosbaar water. Bij bedrijven waar NK-concentraat wordt geproduceerd, zijn er grote verschillen in de hoogte van de waterproductie. Daarbij spelen ook strategische keuzes (voorkomen van zoutschade bij verder op-concentreren) en bedrijfseconomische redenen een rol; immers, wanneer het NK-concentraat op korte afstand afgezet wordt, is er geen reden om een hogere waterproductie na te streven.

- Risico's op emissies van het giftige waterstofsulfide zijn een aandachtspunt bij verwerking van mest en digestaat en bij het blenden van NK-concentraat. Een moeilijkheid hierbij is het ontbreken van standaardanalysemethoden waarmee sulfiden kunnen worden onderscheiden van sulfaat en organische zwavelverbindingen. 


\section{$4 \quad$ Nieuwe membraantechnieken}

\subsection{Ammonia membrane stripping van NK-concentraat door BLUE-tec}

Door het bedrijf BLUE-tec (Renkum) zijn testen gedaan met 'ammonia membrane stripping' (AMS) op het NK-concentraat van GZV. Het doel ervan was om ammoniak (deels) te verwijderen uit het NKconcentraat via AMS om zo een stikstofmeststof en een kaliummeststof te maken.

De techniek maakt gebruik van gas-permeabele membranen en een verschil in gasdruk van ammoniak over het membraan waardoor ammoniak het membraan passeert van de 'feed solution' (het NKconcentraat) naar de 'draw solution'. Aan de draw solution wordt een zuur toegevoegd, in dit geval zwavelzuur, om de $\mathrm{pH}$ lager dan 2,5 te houden. Daardoor wordt het ammoniak afgevangen als ammoniumsulfaatoplossing en blijft de concentratiegradiënt voor ammoniak tijdens het strippen in stand. De $\mathrm{pH}$ van de feed solution werd verhoogd naar 10 door toevoeging van natronloog, zodat praktisch alle opgeloste $\mathrm{N}-\mathrm{NH}_{4}$ aanwezig is als ammoniak. Ook werd een kleine temperatuurgradiënt van $5{ }^{\circ} \mathrm{C}$ aangebracht om het strippen te bevorderen. Een knelpunt dat op kan treden, is vervuiling van het membraan waardoor het membraan zijn hydrofobe eigenschappen verliest; dit heet 'membrane wetting'. Daardoor kan het ook water en zouten door gaan laten. Getest is of dit probleem zich voordoet bij AMS op het NK-concentraat van GZV. Het volledige onderzoeksrapport is opgenomen in Bijlage 4. De belangrijkste bevindingen van de proeven zijn:

- NK-concentraat van GZV lijkt, zonder voorbehandeling, niet geschikt voor AMS, omdat uit testen blijkt dat membrane wetting waarschijnlijk zal optreden. Uit de proeven blijkt dat het door GZV toegevoegde antischuimmiddel een sterke veroorzaker is van membrane wetting. Ook is bekend dat toegevoegde polymeren het kunnen veroorzaken.

- NF als voorbehandeling van het NK-concentraat gevolgd door AMS op het permeaat van de NF kan een efficiënte methode zijn om membrane wetting te voorkomen, omdat hiermee de storende organische componenten worden verwijderd.

- De massa-overdrachtscoëfficiënt voor ammoniak over het AMS-membraan tijdens de proeven lag in de ordegrootte van $1 * 10^{-5} \mathrm{~m} / \mathrm{s}$.

- Gebaseerd op deze uitkomsten is door BLUE-tec een processtroomdiagram opgesteld voor de behandeling van het digestaat van GZV, waarbij MF opgevolgd wordt door NF en waarbij AMS wordt uitgevoerd op het permeaat van de NF. De na AMS overgebleven kaliummeststof, het restant van de 'feed solution', wordt met een RO op-geconcentreerd.

De proeven tonen aan dat AMS van het NK-concentraat, met NF als voorbehandeling, in principe werkt. Het grootste risico daarbij is membrane wetting; als je dat kunt voorkomen, gaan de membranen lang mee, omdat ze vanwege de lage druk weinig mechanische stress te verduren krijgen. De uitgevoerde proeven zijn niet voldoende om vast te kunnen stellen of het proces veelbelovend is ten opzichte van reguliere stripprocessen.

Een voordeel van mestverwerking met AMS is dat ten opzichte van regulier strippen er meer te sturen valt op productkwaliteit. Door aanpassing van de temperatuurgradiënt over het AMS-membraan is namelijk te sturen op de hoeveelheid water die door het membraan heengaat ten opzichte van ammoniak. Bij een hogere temperatuur gaat er ten opzichte van ammoniak relatief meer water doorheen. Ook verbruikt AMS minder energie dan reguliere strippers en is de benodigde installatie compacter.

Een tweede voordeel van mestverwerking met AMS is dat ten opzichte van o.a. elektrodialyse het risico op neerslag van zouten op het membraan klein is. Wanneer $\mathrm{NH}_{3}$ door het membraan heengaat, verschuift het evenwicht $\mathrm{NH}_{4}{ }^{+} \leftrightarrows \mathrm{NH}_{3}+\mathrm{H}^{+}$naar rechts. Daardoor daalt de $\mathrm{pH}$ van de feed solution, wat neerslag van zouten tegenwerkt. Toevoeging van voor bemesting relevante basen zoals $\mathrm{Mg}(\mathrm{OH})_{2}$ 
of $\mathrm{Ca}(\mathrm{OH})_{2}$ om de $\mathrm{pH}$ te verhogen, resulteert hierdoor niet in neerslag van zouten op het membraan zelf. Mocht neerslag plaatsvinden, dan zal dat zijn waar de base wordt toegevoegd, wat mogelijk juist nuttig kan zijn om relevante zouten af te kunnen vangen.

\subsection{Membraandestillatie van NK-concentraat door RN Solutions en Kumac}

Door het bedrijf RN Solutions zijn testen gedaan met membraandestillatie van het NK-concentraat van het bedrijf Kumac, met als doel het scheiden van stikstof en kalium. Dit NK-concentraat heeft een temperatuur van circa $30^{\circ} \mathrm{C}$ als het uit de RO komt en dit werd voor membraandestillatie voorafgaand nog verhoogd tot $45^{\circ} \mathrm{C}$. Membraandestillatie maakt gebruik van een gas-permeabel membraan in combinatie met een door temperatuur veroorzaakt verschil in dampspanning over het membraan. Het in de proeven gehanteerde temperatuurverschil over het membraan is onbekend, maar lag ergens tussen de 20 en $6^{\circ} \mathrm{C}$. Water passeert als waterdamp het membraan en condenseert aan de permeaatzijde tot vloeibaar water. Het hydrofobe membraan houdt vloeistof en de zouten erin tegen die gezamenlijk daarna het retentaat (concentraat van de membraandestillatie) vormen. Vluchtige componenten zoals ammoniak kunnen ook door het membraan heen en eindigen daardoor deels ook in het permeaat. De permeaat-zijde kan, om de temperatuurgradiënt over het membraan te vergroten, gekoeld worden met grondwater, wat jaarrond een temperatuur heeft van rond de $12{ }^{\circ} \mathrm{C}$.

Het ingaande NK-concentraat en het geproduceerde retentaat en permeaat van de proef zijn aangeleverd aan WENR voor chemische analyse en het berekenen van de scheidingsrendementen. Het retentaat bevatte kristallen die zijn afgezeefd waarna een deel ervan met $x$-ray diffraction (XRD) is geanalyseerd en een ander deel na oplossing in zoutzuur nat-chemisch is geanalyseerd door het CBLB. Via de gemeten nutriëntenconcentraties is de bereikte concentratiefactor op massabasis berekend.

De belangrijkste bevindingen van WENR zijn:

- Van de totale massa ingaand NK-concentraat kwam circa $18 \%$ terecht in het retentaat en circa $82 \%$ in het permeaat.

- Het ingaande NK-concentraat werd, op basis van de gemeten concentraties, circa 5,5 keer ingedikt.

- Praktisch $100 \%$ van alle geanalyseerde componenten (P, K, Mg, Ca, Fe, Cu, S, Zn en organische stof) uit het ingaande $\mathrm{NK}$-concentraat kwam terecht in het retentaat. Dit geldt niet voor $\mathrm{N}-\mathrm{NH}_{4}$ : circa $48 \%$ daarvan eindigde in het retentaat en circa $51 \%$ in het permeaat.

- De analyse met x-ray diffraction (XRD) van de zoutkristallen in het retentaat laat zien dat de zwavel aanwezig is in de vorm van sulfaten $\left(\mathrm{K}_{2} \mathrm{SO}_{4}, \mathrm{KSO}_{3}\right.$ en $\left.\mathrm{K}_{3} \mathrm{Na}\left(\mathrm{SO}_{4}\right)_{2}\right)$. Door toename van de concentraties van kat- en anionen zijn deze zouten neergeslagen.

Tabel 4.1 toont de berekende scheidingsrendementen behaald tijdens de proef met membraandestillatie met het NK-concentraat van Kumac. Het ingaande NK-concentraat had een $\mathrm{N}$ $\mathrm{NH}_{4} / \mathrm{K}$-verhouding van $0,83(\mathrm{~m} / \mathrm{m})$. Van de kalium in het ingaande NK-concentraat werd $13 \%$ verwijderd door afzeven van de zoutkristallen in het retentaat. Dit afzeven geeft een (te) kleine verbetering van de verhouding stikstof over kalium, hier berekend als $\mathrm{N}-\mathrm{NH}_{4} / \mathrm{K}$, van 0,44 $(\mathrm{m} / \mathrm{m})$ in het retentaat met zoutkristallen naar 0,39 in het retentaat zonder zoutkristallen. De aanzienlijk lagere $\mathrm{N}$ $\mathrm{NH}_{4} / \mathrm{K}$-verhouding in het retentaat ten opzichte van het ingaande NK-concentraat komt door het meeliften van gasvormig ammoniak met de diffusie van waterdamp door het membraan. Circa $51 \%$ van de $\mathrm{N}-\mathrm{NH}_{4}$ lift met de waterdamp mee door het membraan. Membraandestillatie kan daardoor stikstof verwijderen en dat leidt tot een ongeveer twee keer lagere N/K-verhouding in het retentaat ten opzichte van het ingaande NK-concentraat. Dit resulteert echter wel in een ammoniakwater (permeaat) met een $\mathrm{pH}$ van 9. 
Tabel 4.1 Berekend scheidingsrendement naar het retentaat, de afgezeefde zoutkristallen en het permeaat voor de membraandestillatieproef als percentage van het ingaande $\mathrm{NK}$-concentraat van Kumac. ${ }^{1,2}$

\begin{tabular}{|c|c|c|c|}
\hline Parameter & Retentaat (inclusief zoutkristallen) & Zoutkristallen (afgezeefd) & Permeaat \\
\hline Massa & 18 & 0,015 & 82 \\
\hline $\mathrm{N}-\mathrm{NH}_{4}$ & 48 & 0,8 & 51 \\
\hline $\mathrm{K}$ & 100 & 12,7 & n.b. \\
\hline $\mathrm{Mg}$ & 100 & 11,7 & n.b. \\
\hline $\mathrm{Fe}$ & 100 & 0,7 & n.b. \\
\hline $\mathrm{Cu}$ & 100 & n.b. & n.b. \\
\hline $\mathrm{S}$ & 100 & 10,9 & n.b. \\
\hline
\end{tabular}

1 Massa: totale massa van de processtroom.

2 n.b.: niet berekend, kan niet berekend worden vanwege een of meerdere gemeten concentraties onder de kwantificeringslimiet (LOQ).

Wil je het meeliften van ammoniak en de hoge $\mathrm{pH}$ van het permeaat voorkomen, dan moet de $\mathrm{pH}$ van het NK-concentraat voorafgaand aan en tijdens de membraandestillatie verlaagd worden tot naar verwachting onder de 7. Dat kost echter veel (zwavel)zuur vanwege de bufferende werking van NKconcentraat door o.a. de aanwezigheid van bicarbonaten. Toevoeging van een zuur, specifiek ook zwavelzuur, beïnvloedt mogelijk de hoeveelheid kalium die als zoutkristal neerslaat. Ook is, net zoals bij AMS, membrane wetting een risico bij membraandestillatie. De grootte van dit risico is echter niet onderzocht in de uitgevoerde proeven.

Kortom, membraandestillatie kan een grote indikking van NK-concentraat behalen, waarbij echter wel zuurtoevoeging nodig is om te voorkomen dat $\mathrm{N}-\mathrm{NH}_{4}$ het membraan passeert. Door het indikken slaan kaliumzouten neer, waarbij kristallen worden gevormd die groot genoeg zijn om met een zeef af te scheiden. De techniek biedt daarmee perspectief voor de scheiding van stikstof en kalium indien het percentage als zoutkristallen afgevangen kalium kan worden verhoogd. De volledige memo over de proef is opgenomen in Bijlage 2. 


\section{$5 \quad$ Agronomische en milieukundige kwaliteit eindproducten}

\subsection{Mest en digestaat}

Tabel 5.1 toont de gemiddelde samenstelling van de ingaande mest en het ingaande digestaat van de installaties van de verwerkers om vergelijking van de samenstelling van de eindproducten met de ingaande mest of het ingaande digestaat mogelijk te maken.

De samenstelling van de ingaande varkensdrijfmest van Van Amstel en Merensteyn en het ingaande digestaat van Dekker zijn onderling vergelijkbaar met drogestofgehalten van 64 tot $70 \mathrm{~g} / \mathrm{kg}$, een stikstofgehalte van 4,8 tot $5,5 \mathrm{~g} / \mathrm{kg}$ en een fosfaatgehalte van 2,1 tot $3,1 \mathrm{~g} \mathrm{P}_{2} \mathrm{O}_{5}$ per $\mathrm{kg}$. Dekker voert co-vergisting uit, maar de bijdrage van de co-producten is echter beperkt, waardoor dit niet leidt tot een substantieel andere samenstelling t.o.v. de niet-vergiste mesten. De digestaten van Ecoson en GZV hebben hogere gehalten aan fosfaat en stikstof door het meevergisten van ongeboren mest en, voor GZV, co-producten. Ook zijn er verschillen in de verhouding $\mathrm{N}-\mathrm{NH}_{4} / \mathrm{N}$, die relatief laag is voor het digestaat van Ecoson en GZV (respectievelijk 53\% en 64\%) ten opzichte van de niet-vergiste mesten met een verhouding $\mathrm{N}-\mathrm{NH}_{4} / \mathrm{N}$ van $73 \%$ of meer.

Ter vergelijking is ook de samenstelling van varkensdrijfmesten uit het project 'Monitoring van installaties voor mineralenconcentraten' (Hoeksma et al., 2021a) opgenomen, waarin negen bedrijven deelnemend aan de Pilot Mineralenconcentraat zijn gemonitord. Hoeksma heeft de gemiddelde samenstelling per bedrijf gerapporteerd. In Tabel 5.1 is het gemiddelde van de negen bedrijven opgenomen en tevens de hoogste en laagste waarde. Het betreft mestmonsters (geen digestaat of digestaat van co-vergisting). De samenstelling komt overeen met de samenstelling van de mesten bij Merensteyn en Van Amstel, met uitzondering van het gehalte $\mathrm{N}-\mathrm{NH}_{4}$ en de verhouding $\mathrm{N}-\mathrm{NH}_{4} / \mathrm{N}$, die gemiddeld wat lager is in de monitoring van de pilot van Hoeksma. 


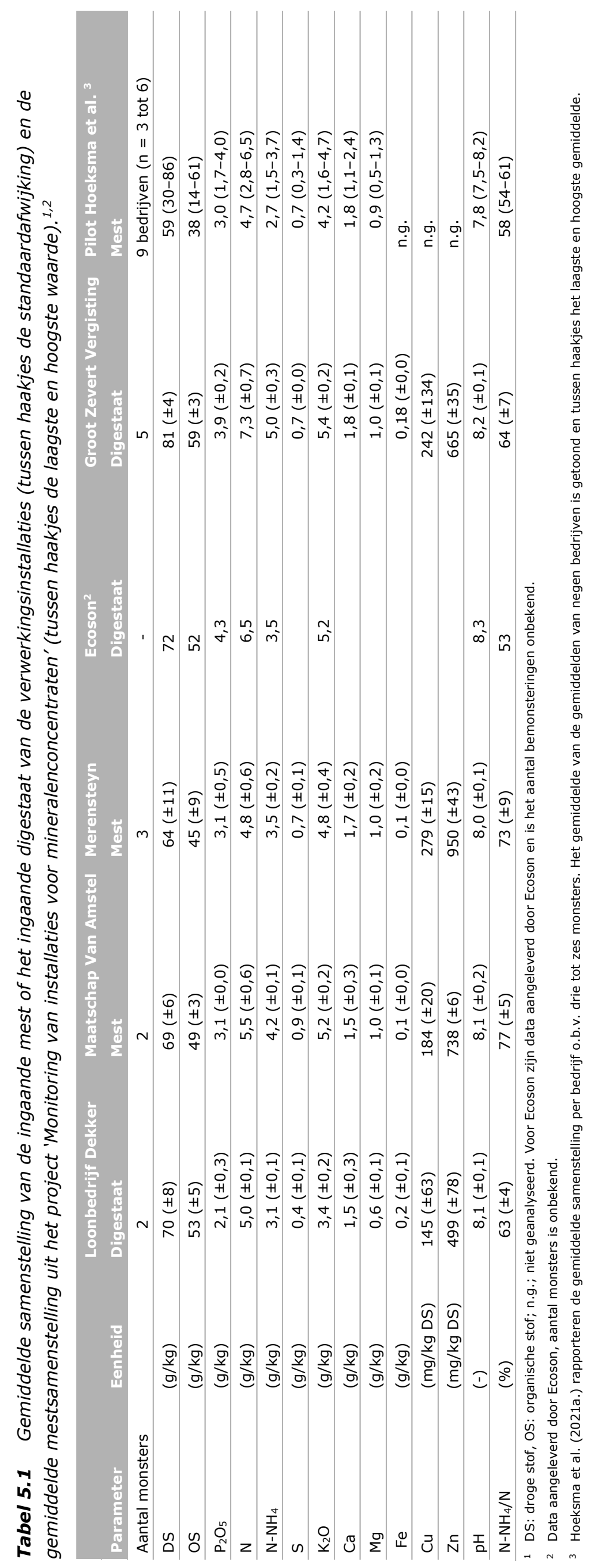

86 | Wageningen Environmental Research Rapport 3120 


\subsection{NK-concentraten en dunne fracties}

\subsubsection{Samenstelling}

Tabel 5.2 toont de gemiddelde samenstelling van de bemonsterde NK-concentraten van Van Amstel, Merensteyn en GZV. Daarnaast is de gemiddelde samenstelling van de dunne fractie van Dekker en het MF-concentraat van GZV weergegeven.

De samenstelling van de NK-concentraten varieert tussen de in dit project gemonitorde verwerkers. Het stikstofgehalte in de NK-concentraten ligt tussen 5,6 en $8 \mathrm{~g} / \mathrm{kg}$ en is gemiddeld over Van Amstel, Merensteyn en GZV voor $96 \%$ aanwezig als mineraal stikstof $\left(\mathrm{N}-\mathrm{NH}_{4}\right)$. Daarnaast zijn er verschillen in het zwavelgehalte, dat varieert van 1,6 tot $5,4 \mathrm{~g} / \mathrm{kg}$ en daarmee hoger is dan in de dunne fractie van mest. Dit is een gevolg van de chemietoevoeging (zwavelzuur en ijzersulfaat) op de verwerkingsinstallaties. Het NK-concentraat van GZV heeft een laag zwavelgehalte, omdat GZV bewust heeft gekozen voor andere procescondities waardoor geen ijzersulfaat en slechts een beperkte hoeveelheid zwavelzuur wordt toegevoegd. Ook zijn er verschillen in de hoogte van het fosfaatgehalte van het NK-concentraat. Verwerkers die ijzersulfaat toevoegen (Van Amstel en Merensteyn), realiseren een $\mathrm{P}_{2} \mathrm{O}_{5}$ gehalte onder de aantoonbaarheidsgrens van $0,1 \mathrm{~g} / \mathrm{kg}$. Het $\mathrm{NK}$-concentraat van GZV bevat gemiddeld $0,3 \mathrm{~g} \mathrm{P}_{2} \mathrm{O}_{5} \mathrm{~kg}$ zonder dat hiervoor ijzerzouten worden toegevoegd. De verhouding stikstof/kali in het NK-concentraat is daarentegen nagenoeg gelijk voor alle verwerkers. De samenstelling van de NK-concentraten past binnen de range van waarden die zijn gerapporteerd voor 17 bedrijven uit het project 'Monitoring van installaties voor mineralenconcentraten' (Hoeksma et al., 2021a). De gemiddelde verhouding $\mathrm{N}-\mathrm{NH}_{4} / \mathrm{N}$ in de $\mathrm{NK}$-concentraten uit dat project is lager dan die in de NK-concentraten van Van Amstel, Merensteyn en GZV. Dat project toont eveneens een zeer grote spreiding in het zwavelgehalte van de NK-concentraten. Een toetsing aan de criteria voor RENURE-materialen is onderdeel van paragraaf 5.2.2.

Dekker produceert een dunne fractie waardoor het stikstofgehalte lager is dan in NK-concentraat. De dunne fractie bevat nog circa $0,6 \mathrm{~g} \mathrm{P}_{2} \mathrm{O}_{5} / \mathrm{kg}$, omdat de scheiding is uitgevoerd met een zeefbandpers zonder nabehandeling en zonder gebruik van ijzerzouten. Dekker zet de dunne fractie af onder de gebruiksnorm dierlijke mest en er is daarom geen reden om het fosfaatgehalte verder te verlagen. GZV produceert tevens een MF-concentraat (slib van de microfiltratie) met een drogestofgehalte van $49 \mathrm{~g} / \mathrm{kg}$ en een stikstofgehalte van $7,1 \mathrm{~g} / \mathrm{kg}$. De microfiltratie dient om fosfaat en fijne organische stof te verwijderen en dit verklaart de relatief lage verhouding $\mathrm{N}-\mathrm{NH}_{4} / \mathrm{N}$ en de aanwezigheid van fosfaat $\left(0,9 \mathrm{~g} \mathrm{P}_{2} \mathrm{O}_{5} / \mathrm{kg}\right)$ in het concentraat van de microfiltratie. Door het relatief lage fosfaatgehalte is dit concentraat - net als de dunne fractie van Dekker - goed plaatsbaar in akkerbouw binnen Nederland onder de gebruiksnorm dierlijke mest. 


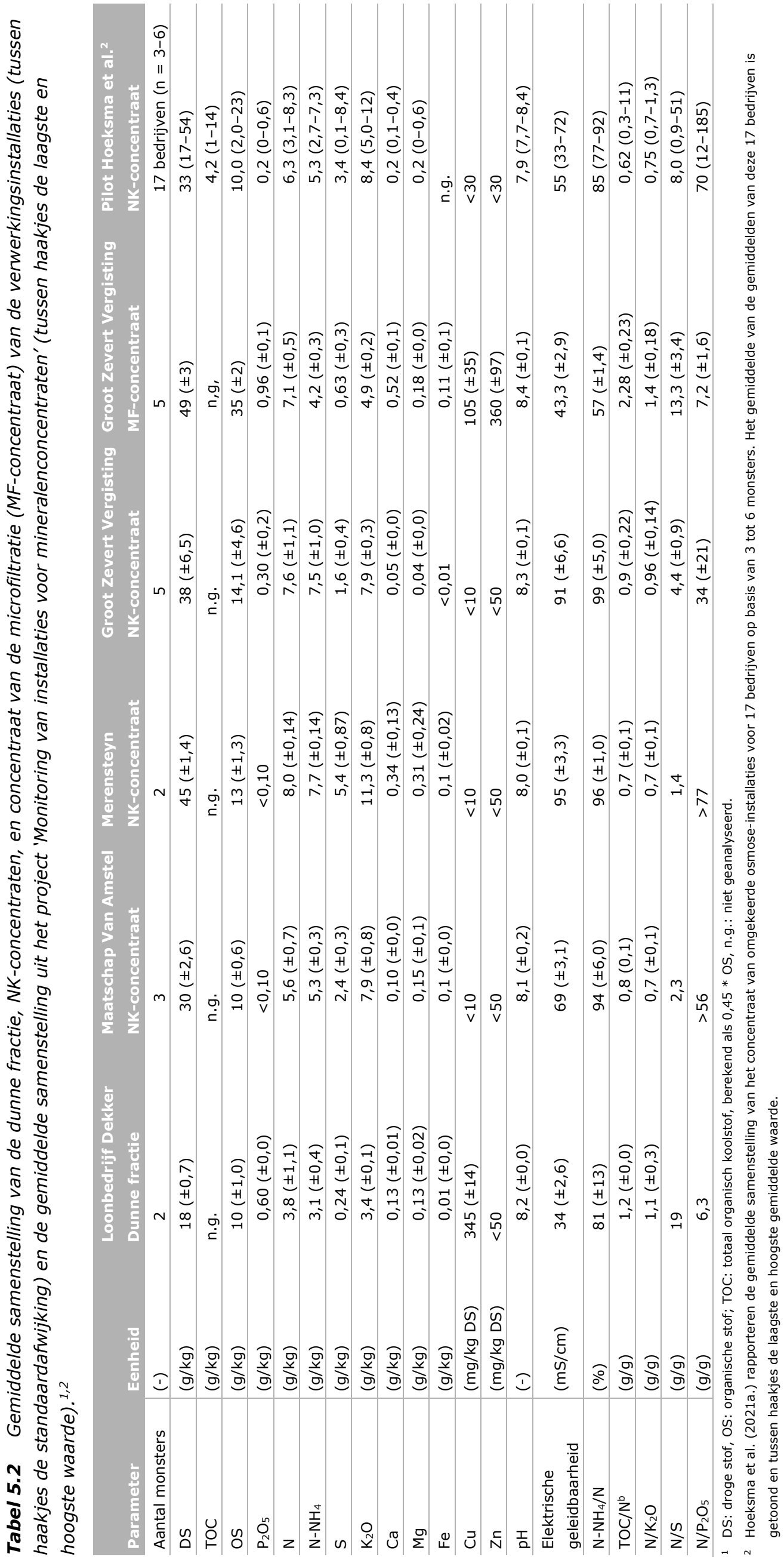




\subsubsection{Criteria kunstmestvervanger}

Het NK-concentraat geproduceerd uit mest of uit digestaat van (co-vergiste) mest valt onder de definitie van dierlijke mest en daarmee onder de gebruiksnorm dierlijke mest (170 kg N/ha of 230/250 kg N/ha bij derogatie voor graasdierbedrijven). Echter, er zijn ontwikkelingen gaande die het mogelijk maken om NK-concentraat onder voorwaarden te gebruiken als 'kunstmeststikstofvervanger' boven op de gebruiksnorm dierlijke mest. Net als voor stikstofkunstmest blijft de stikstofgebruiksnorm wel van toepassing en geldt een werkingscoëfficiënt van $100 \%$ voor het NK-concentraat bij gebruik als kunstmestvervanger.

Voorwaarden voor de toepassing van NK-concentraten boven op de gebruiksnorm dierlijke mest zijn opgenomen in de tijdelijke pilot 'mineralenconcentraten', die nog doorloopt tot eind 2021, en de tijdelijke gebiedsgerichte pilot Kunstmest-Vrije Achterhoek (KVA). Deze pilots horen bij het $6^{e}$ Actieprogramma van Nederland in het kader van de Nitraatrichtlijn. Het zijn tijdelijke pilots bedoeld om praktijkervaring te ontwikkelen over het gebruik van NK-concentraat of blends van NK-concentraat met andere stikstofmeststoffen.

Het beleidsproces voor een definitieve vrijstelling van NK-concentraten van de gebruiksnorm dierlijke mest is nog gaande. Besluitvorming hiervoor ligt bij de Europese Commissie (EC), omdat de gebruiksnorm dierlijke mest is vastgelegd in de Nitraatrichtlijn (91/676/EEC) ter bescherming van grondwater in gebieden die gevoelig zijn voor uitspoeling van nitraat (Nitrate Vulnerable Zones). Het JRC, de onderzoeksinstelling van de Europese Commissie, heeft onder de werknaam 'SafeManure' een onderzoek uitgevoerd naar en criteria geformuleerd waaronder stikstofhoudende meststoffen, geproduceerd uit dierlijke mest, kunnen worden toegepast boven op de gebruiksnorm dierlijke mest, zonder dat dit leidt tot een verhoogd risico op nitraatuitspoeling ten opzichte van gebruik van kunstmest (Huygens et al., 2020). Het JRC gebruikt voor dergelijke producten de term 'REcovered Nitrogen from manURE', afgekort RENURE. Inpassing van een materiaal als bemestingsproduct gemaakt van mest onder de RENURE-criteria is bedoeld om aanwending ervan binnen de regio te bevorderen en heeft geen relatie met de nieuwe Europese Meststoffenwet die de vrije handel in meststoffen regelt.

De voor de pilot mineralenconcentraten en de pilot KVA geldende criteria en de RENURE-criteria worden hieronder toegelicht.

\section{Criteria pilot mineralenconcentraten}

Het ministerie heeft een ontheffing gegeven voor tien mest verwerkende bedrijven die deelnemen aan de pilot mineralenconcentraten ${ }^{8}$, wat inhoudt dat bedrijven onder voorwaarden mineralenconcentraat mogen gebruiken als kunstmestvervanger waarop de gebruiksnorm dierlijke mest niet van toepassing is. De stikstofgebruiksnorm blijft wel van toepassing en de werkingscoëfficiënt voor mineralenconcentraten is gelijk gesteld aan die van minerale stikstofkunstmest (100\%). Het mineralenconcentraat moet voldoen aan de volgende criteria:

- gehalte van $\mathrm{N}-\mathrm{NH}_{4}$ is minimaal $90 \%$ van het gehalte totaal stikstof $(\mathrm{N})$;

- verhouding stikstof $(\mathrm{N})$ tot fosfaat $\left(\mathrm{P}_{2} \mathrm{O}_{5}\right)$ is minimaal 15 op massabasis; en

- elektrische geleidbaarheid van het product is minimaal $50 \mathrm{mS} / \mathrm{cm}$.

De minister heeft besloten deze pilot te verlengen tot 31 december 2021. Van Amstel en Merensteyn maken gebruik van deze vrijstelling. In totaal zijn er circa 300 landbouwers die onder deze vrijstelling mineralenconcentraat afnemen als kunstmestvervanger en toepassen op hun land voor de teelt van gewassen.

\section{Criteria pilot Kunstmestvrije Achterhoek}

Het ministerie heeft een ontheffing gegeven voor de gebiedsgerichte pilot 'kunstmestvrije Achterhoek'. Onder deze pilot zet GZV een blend van NK-concentraat en andere stikstofmeststoffen af in de regio onder de merknaam 'Groene Weide Meststof'. De stikstof in deze blend is voor ten minste $75 \%$ herwonnen stikstof. Daarnaast gelden voor het mineralenconcentraat dezelfde eisen als die voor deelname van de producent aan de pilot Mineralenconcentraat.

\footnotetext{
8 Staatscourant 2014-37693
} 


\section{Voorlopige criteria RENURE-producten}

Het JRC (Huygens et al., 2020) heeft de volgende definitie (ingekort) geformuleerd:

"RENURE-producten ontstaan na een fysische/chemische of biologische verwerkingsstap, anders dan louter mixen, blenden, drogen of granuleren en leidt tot een verhoging van de concentratie van mineraal $\mathrm{N}$ ten opzichte van het ingaande materiaal. ${ }^{9}$

Een dunne fractie van mestscheiding zonder nabehandeling door omgekeerde osmose kan niet voldoen aan de definitie van RENURE, omdat in dit geval geen sprake is van concentratieverhoging."

Daarnaast zijn enkele product-specifieke criteria voorgesteld en enkele generieke criteria die de beschermingsdoelen van de Nitraatrichtlijn dienen, namelijk:

- een maximale ratio van organisch koolstof ten opzichte van totaal stikstof (TOC/N) van 3; en

- een minimaal procentuele verhouding van mineraal stikstof $\left(\mathrm{N}-\mathrm{NH}_{4}+\mathrm{N}-\mathrm{NO}_{3}\right)$ ten opzichte van totaal stikstof van $90 \%$ (RENURE-producten kunnen zowel $\mathrm{N}-\mathrm{NH}_{4}$ als $\mathrm{N}-\mathrm{NO}_{3}$ bevatten); en

- een kopergehalte van $<300 \mathrm{mg} / \mathrm{kg}$ droge stof en een zinkgehalte van $<800 \mathrm{mg} / \mathrm{kg}$ droge stof.

Voor RENURE-producten met een $\mathrm{pH}$ hoger dan 5,5 en een verhouding $\mathrm{N}-\mathrm{NH}_{4} / \mathrm{N}$ groter dan $60 \%$ is daarnaast een voorwaarde voor emissiearme toediening en opslag opgenomen. Bovengenoemde criteria zijn een advies aan de EC, definitieve criteria voor RENURE-producten zijn niet vastgesteld. Er vinden nog discussies plaats en mogelijk komen er aanvullende criteria of veranderingen in bovengenoemde criteria. De verwachting is dat in 2021 de contouren van het beleid rond RENUREproducten duidelijk worden. Daarna volgt de nationale beleidsafweging, wat kan resulteren in aanpassingen in nationaal toegestaan gebruik van deze stikstofhoudende bemestingsproducten van dierlijke mest die mogelijk in 2023 van kracht kunnen worden.

\subsubsection{Toetsing aan criteria}

De NK-concentraten van de vier in dit project gemonitorde bedrijven voldoen aan de criteria van de pilot mineralenconcentraten $\left(\mathrm{N}-\mathrm{NH}_{4} / \mathrm{N}>90 \%, \mathrm{EC}>50 \mathrm{mS} / \mathrm{cm}\right.$ en $\mathrm{N} / \mathrm{P}_{2} \mathrm{O}_{5}>15 \mathrm{~kg} / \mathrm{kg}$ ). Bij de individuele monsters werd eenmaal een verhouding $\mathrm{N}-\mathrm{NH}_{4} / \mathrm{N}$ van $88 \%$ gemeten. De NK-concentraten voldoen ook aan de RENURE-criteria (want $\mathrm{N}-\mathrm{NH}_{4} / \mathrm{N}>90 \%$ en TOC/N $<3 \mathrm{~kg} / \mathrm{kg}$ ). Bij handhaving van het criterium $\mathrm{N}-\mathrm{NH}_{4} / \mathrm{N}$ moet ook de foutmarge van de chemische analyses, en de daaruit resulterende kans dat een monster onterecht niet aan het criterium voldoet, in acht worden genomen. De grenswaarde voor de verhouding TOC/N werd bij geen enkele afzonderlijke meting overschreden. Een kanttekening hierbij is dat het TOC-gehalte berekend is uit het organischestofgehalte (bepaald via gloeiverlies) met een omrekenfactor van 0,50, omdat het lab van LUFA NRW geen methode heeft om TOC in mest te meten.

Gehalten aan koper en zink in de NK-concentraten zijn lager dan de aantoonbaarheidsgrens en voldoen daarmee ruimschoots aan de RENURE-criteria van $300 \mathrm{mg} / \mathrm{kg}$ droge stof voor koper en $500 \mathrm{mg} / \mathrm{kg}$ droge stof voor zink. In de ruwe mest en in het digestaat zijn koper en zink wel aanwezig in gehalten boven deze criteria. In het scheidingsproces worden deze metalen - die binden aan organische stof of precipiteren met sulfiden - afgevangen in de dikke fractie of het concentraat van de microfiltratie. Hierdoor zijn de gehalten aan koper en zink in de NK-concentraten niet van milieukundige betekenis, terwijl de dikke fracties wel relatief hoge gehalten aan koper en zink hebben (paragraaf 5.3).

De dunne fractie (Dekker) en het concentraat van de microfiltratie (GZV) voldoen niet aan de definitie van een RENURE-materiaal, omdat er geen sprake is van op-concentreren van $\mathrm{N}-\mathrm{NH}_{4}$. Ook voldoen deze meststoffen niet aan het criteria voor de minimale verhouding $\mathrm{N}-\mathrm{NH}_{4} / \mathrm{N}$. Deze meststoffen worden als mest - dus binnen de gebruiksnorm dierlijke mest - afgezet naar de landbouw en er is

\footnotetext{
9 De volledige definitie luidt: RENURE is obtained through a process where the handling chain for the manure(s) applied as input material involves a physical, chemical, or biological process step for the treatment of manure other than solely mixing, blending, drying, rewetting, granulation and/or storage, that increases the concentration of mineral $N$, urea $N$ and/or crystal-bound $N$ (\% relative to total $N$ ) compared to the input material(s). The production process results in materials of a consistent quality that is in compliance with all other criteria.
} 
voor deze meststoffen geen perspectief op gebruik als kunstmestvervanger onder RENURE. Dekker zou door implementatie van een nabehandeling (DAF of microfiltratie) gevolgd door omgekeerde osmose de dunne fractie wel kunnen opwerken tot een NK-concentraat dat voldoet aan de RENUREcriteria.

\subsubsection{Evaluatie landbouwkundige kwaliteit}

\section{Stikstof}

Er zijn verschillen in het stikstofgehalte van de NK-concentraten, de mate van concentreren van de ingaande dunne fractie is hoofdzakelijk een economische afweging tussen lagere opslag- en transportkosten tegenover hogere kosten voor energie- en chemieverbruik. Daarnaast speelt ook de toename van het risico op ammoniakemissies bij opslag en aanwending en zoutschade bij de gewassen mee in deze afweging. NK-concentraten kenmerken zich door een relatief hoge $\mathrm{pH}$-waarde $(>8,0)$, waardoor risico's op ammoniakemissies groot zijn. De pH van NK-concentraat is daarmee gelijk aan de $\mathrm{pH}$ van onbewerkte mest en dunne fractie. De toevoeging van zwavelzuur voor de omgekeerde osmose heeft geen meetbaar effect op de $\mathrm{pH}$ van het NK-concentraat; vermoedelijk omdat $\mathrm{NK}$-concentraat $\mathrm{CO}_{2}$ bevat wat door ontgassing ontsnapt waardoor de $\mathrm{pH}$-waarde stijgt, en door de $\mathrm{pH}$-bufferende werking van o.a. het zuur-base koppel $\mathrm{NH}_{4}{ }^{+} / \mathrm{NH}_{3}$ en - indien aanwezig $\mathrm{H}_{2} \mathrm{~S} / \mathrm{HS}^{-} / \mathrm{S}^{2-}$. Emissiearme opslag en aanwending van $\mathrm{NK}$-concentraten is vanwege de hoge $\mathrm{pH}$ verplicht. Emissiefactoren worden besproken in hoofdstuk 7. In NK-concentraat is de stikstof voor $>90 \%$ aanwezig als $\mathrm{N}-\mathrm{NH}_{4}$. Bij dunne fractie is dit percentage lager $\left(\mathrm{N}-\mathrm{NH}_{4} / \mathrm{N}=80 \%\right)$, maar evenwel hoog t.o.v. niet-gescheiden mest of digestaat. Het concentraat van de microfiltratie heeft juist een lage verhouding $\mathrm{N}-\mathrm{NH}_{4} / \mathrm{N}$ doordat microfiltratie organisch stikstof afvangt.

\section{Kalium}

De verhouding stikstof/kali $\left(\mathrm{N} / \mathrm{K}_{2} \mathrm{O}\right)$ is nagenoeg gelijk in het $\mathrm{NK}$-concentraat van de drie verwerkers en ligt tussen de 0,6 en $0,8 \mathrm{~kg} \mathrm{~N} / \mathrm{kg} \mathrm{K} \mathrm{K}_{2} \mathrm{O}$. De samenstelling van de ingaande mest en het ingaande digestaat is hierin sturend. Op grasland is een te hoge kaliumdosering ongewenst vanwege het risico op kopziekte bij runderen. Bij deze gemeten verhoudingen $\mathrm{N} / \mathrm{K}_{2} \mathrm{O}$ is voor de meeste open teelten (grasland en akkerbouw) vaak extra aanvoer van stikstof nodig. Bij enkele gewassen, o.a. bij aardappelen, is juist extra aanvoer van kalium nodig. Er zijn daardoor ruimere afzetmogelijkheden voor een NK-concentraat, of een blend hiervan, met een hogere verhouding $\mathrm{N} / \mathrm{K}_{2} \mathrm{O}$ (Schoumans et al., 2012). In het kader van dit project zijn proeven gedaan om stikstof en kalium met 'ammonia membrane stripping' of met membraandestillatie van elkaar te scheiden. De met deze technieken behaalde scheidingsrendementen zijn vooralsnog beperkt (hoofdstuk 4). Het blenden van NKconcentraat met een andere stikstofmeststof ligt daardoor meer voor de hand.

\section{Fosfaat}

Fosfaat in NK-concentraat is ongewenst, omdat het meetelt voor de fosfaatgebruiksnorm en die is over het algemeen al opgevuld met de toegebrachte basisgift aan dierlijke mest. In de pilot mineralenconcentraten is daarom een minimale verhouding $\mathrm{N} / \mathrm{P}_{2} \mathrm{O}_{5}(>15 \mathrm{~kg} / \mathrm{kg}$ ) opgenomen, waarmee de verplichting tot meetellen van het fosfaat in NK-concentraat in de fosfaatgebruiksnorm vervalt. Voor RENURE-materialen wordt naar verwachting en overeenkomstig de nieuwe EUmeststoffenwetgeving een ondergrens van $0,1 \mathrm{~g} \mathrm{P}_{2} \mathrm{O}_{5} / \mathrm{kg}$ aangehouden. Bij overschrijding van die waarde is meetellen van het als NK-concentraat aangewende fosfaat verplicht. Om zulke lage fosfaatgehalten in het NK-concentraat te behalen, is voor de huidige verwerkingstechnieken toevoeging van chemie als ijzersulfaat, ijzerchloride of magnesiumchloride noodzakelijk. Een keerzijde van de toevoeging van zulke chemie is, naast de kosten ervoor, dat het leidt tot verhoging van gehalten aan ongewenste componenten (sulfaat, chloride) in het eindproduct. Het GENIAAL-systeem van GZV heeft een microfiltratie-installatie om met een lagere chemietoevoeging fosfaat te kunnen verwijderen. Echter, ortho-fosfaat passeert de microfiltratie-membranen waardoor het NK-concentraat een gemiddeld fosfaatgehalte van $0,3 \mathrm{~g} / \mathrm{kg}$ heeft $\left(0,1\right.$ tot $0,5 \mathrm{~g} \mathrm{P}_{2} \mathrm{O}_{5}$ per $\left.\mathrm{kg}\right)$. Bij het vaststellen van een ondergrens voor het fosfaatgehalte in RENURE-producten, voor vrijstelling van de fosfaatgebruiksnorm, wordt aanbevolen om ook de nadelen van toevoeging van ijzer- of magnesiumzouten op de landbouwkundige kwaliteit van het product mee te nemen. 
Dunne fractie en concentraat van de microfiltratie bevatten fosfaat dat geen belemmering vormt, omdat ze onder de gebruiksnorm voor dierlijke mest worden afgezet en de verhouding $\mathrm{N} / \mathrm{P}_{2} \mathrm{O}_{5}$ voldoende hoog is voor inpassing in het bemestingsplan.

\section{Zwavel}

Zwavelgehalten in de NK-concentraten zijn verhoogd ten opzichte van de ingaande mest of het ingaande digestaat door toevoeging van sulfaat $\left(\mathrm{SO}_{4}{ }^{2-}\right)$ in de vorm van zwavelzuur en ijzersulfaat. Hierdoor is zwavel nagenoeg volledig aanwezig in minerale vorm in tegenstelling tot een organische meststof, waarbij een deel van het zwavel aanwezig is in organische vorm. Door verschillen in de hoogte van chemiedosering zijn er verschillen in het zwavelgehalte van de NK-concentraten $(1,6-$ $5,4 \mathrm{~g} / \mathrm{kg}$ ). De dunne fractie (Dekker) bevat daarentegen nauwelijks zwavel $(0,2 \mathrm{~g} / \mathrm{kg})$.

Zwavel is een macro-nutriënt, echter de gewasbehoefte ervan is beperkt en de basisbemesting met dierlijke mest voorziet al grotendeels in die behoefte. Voor grasland op zandgrond is een aanvullende zwavelgift passend voor de eerste en tweede snede. Voor latere sneden heeft gras geen behoefte aan extra zwavelbemesting (Tabel 5.3) en dient het zwavelgehalte van de aangewende meststof zo laag mogelijk te zijn. Voor akkerbouwgewassen op kleigrond is een extra zwavelgift vaak overbodig.

Een zwavelgift boven de gewasopname geeft verhoogde risico's op (i) een verlaagde opname van sporenelementen en (ii) uitspoeling van sulfaat naar het grondwater.

(i) Een zwavelgift boven de gewasopname kan leiden tot een verlaagde opname van sporenelementen en bij gras voor een lagere benutting van sporenelementen door het grasetende dier. ${ }^{10}$ De gemiddelde zwavelbalans van de Nederlandse landbouwbodem is positief, wat betekent dat de gemiddelde aanvoer van zwavel hoger is dan de gewasopname (Ehlert en Chardon, 2014).

(ii) Zwavel in de vorm van sulfaat $\left(\mathrm{SO}_{4}{ }^{2-}\right)$ is zeer mobiel en bij bemesting boven de gewasopname zal het overschot uitspoelen naar het grond- en oppervlaktewater. Dit kan milieubezwaarlijk zijn wanneer reductie ervan tot sulfide optreedt, wat leidt tot interne eutrofiëring. Dit houdt in dat sulfaat onder anaerobe (zuurstofloze) omstandigheden wordt omgezet naar sulfide wat precipiteert met ijzer in de bodem. Daardoor neemt de binding van fosfaat aan ijzer af en komt er fosfaat vrij. Voor zandgronden is het sulfaatgehalte in grondwater van nature laag, gemiddeld $50 \mathrm{mg} \mathrm{SO}_{4} / \mathrm{l}$ (17 mg S/l), en kan de bemestingsbijdrage aan de sulfaatconcentratie in grondwater aanzienlijk zijn. In drinkwaterwingebieden is uitspoeling van sulfaat ongewenst. Voor drinkwater geldt een norm van maximaal $150 \mathrm{mg} \mathrm{SO} / \mathrm{l}$ (50 mg S/I), omdat reductie van sulfaat in pijpleidingen leidt tot corrosie. Daarentegen wordt de sulfaatconcentratie in klei- en veengebieden voornamelijk bepaald door de achtergrondconcentratie die van nature al hoog is (180 $\mathrm{mg} \mathrm{SO}_{4} / \mathrm{l}$, $60 \mathrm{mg} \mathrm{S} / \mathrm{I}$ ), waardoor de bijdrage van bemesting relatief gezien beperkt is (Fraters en Goffau, 2015). Er is geen gebruiksnorm die de bemesting met zwavel beperkt. Met name bij toediening van gips ter verbetering van de bodemstructuur op kleigronden worden grote hoeveelheden zwavel gedoseerd. De Commissie Deskundigen Meststoffenwet (CDM, 2014) heeft eerder een advies geschreven over zwavelhoudende meststoffen en adviseert om regels te stellen aan het gebruik van zwavelhoudende meststoffen. Dit om te voorkomen dat de sulfaatconcentratie in grond- en oppervlaktewater significant stijgt als gevolg van overdosering van sulfaat via mest- en reststoffen.

Tabel 5.3 Zwavelbemestingsadvies in $\mathrm{kg} S$ per ha voor grasland op zandgronden voor de eerste en tweede snede. Bij latere sneden is zwavelbemesting niet gewenst (handboekbemesting.nI).

\begin{tabular}{cccc} 
Zwavel-leverend vermogen van de bodem & Advies eerste snede & Advies tweede snede \\
\hline$<6$ & 20 & 20 \\
\hline $6-11$ & 15 & 15 \\
\hline $12-17$ & 15 & 15 \\
\hline$>17$ & 0 & 0 \\
\hline
\end{tabular}

${ }^{10}$ www. bemestingsadvies.nl 
De stikstofgift voor de eerste en tweede snede varieert met stikstof-leverend vermogen van de bodem (NLV), het grasland gebruik (maaien, weiden), droogtegevoeligheid van de bodem en de opbrengst die de graasveehouder wil realiseren. Het stikstofbemestingsadvies voor grasland is daardoor gedifferentieerder dan die voor zwavel. De volgende waarden voor stikstofgiften zijn louter indicatief. Bij een opbrengstklasse van meer dan 3 ton droge stof/ha en een NLV van 140 is voor de $1^{\mathrm{e}}$ maaisnede circa $100 \mathrm{~kg} \mathrm{~N} /$ ha nodig en voor een $2^{\mathrm{e}} 80 \mathrm{~kg} \mathrm{~N} / \mathrm{ha}$. Wordt geweid, dan zijn deze giften circa 80 en $35 \mathrm{~kg} \mathrm{~N} / \mathrm{ha}$. Deze waarden geven een groot bereik in N/S-verhoudingen. De aanvoer van zwavel met mest dwingt tot de productie van relatief zwavelarme, stikstofhoudende bemestingsproducten die aanvullend worden gegeven: met relatief hoge N/S-verhoudingen $(>5)$.

\section{Waterstofsulfide en veiligheid}

Een ander aandachtspunt bij toevoeging van sulfaat-houdende chemie bij de productie van NKconcentraat is het verhoogde risico op vorming van giftig waterstofsulfide $\left(\mathrm{H}_{2} \mathrm{~S}\right)$ bij opslag van de meststof onder zuurstofloze condities. De snelheid waarmee waterstofsulfide wordt gevormd, hangt af van hoeveel biologisch afbreekbaar organische stof aanwezig is in het NK-concentraat. Bacteriën benutten die organische stof om sulfaat te reduceren tot waterstofsulfide, een kleurloos gas dat bij lage concentraties de kenmerkende geur van rotte eieren heeft. Bij hogere concentraties wordt door verlamming van het reukvermogen de geur niet meer waargenomen en kan blootstelling leiden tot letsel of overlijden (Tabel 5.4).

Waterstofsulfide kan ontstaan in mestkelders van boerenbedrijven en mest- en digestaatverwerkers. Desondanks worden de risico's van waterstofsulfide in de praktijk nog altijd onderschat, met alle gevolgen van dien. Het mengen van zwavelrijk NK-concentraat met (al dan niet gescheiden) drijfmest gevolgd door opslag van dit mengsel wordt afgeraden, omdat mest goed afbreekbare organische stof bevat waardoor de risico's op vorming van waterstofsulfide met de opslagtijd toenemen. Daarom is het verboden om spuiwater van luchtwassers te mengen met mest.

Risico's op blootstelling van medewerkers aan waterstofsulfide treden op bij situaties waarin de mest wordt gemixt, verpompt of waarin op een andere manier de uitwisseling van opgelost waterstofsulfide met de lucht wordt bevorderd (Dai et al., 2013). In Nederland geldt een MAC- (Maximum Allowable Concentration) waarde van $2,3 \mathrm{mg} / \mathrm{m}^{3}(1,6 \mathrm{ppm})$ als tijd-gewogen gemiddelde concentratie bij blootstelling gedurende acht uur. Duitsland hanteert daarnaast een MAC-waarde van $10 \mathrm{ppm}$ bij blootstelling gedurende 15 minuten. ${ }^{11}$ Bij praktijkmetingen van Wageningen Livestock Research in een mestkelder (drijfmest zonder toevoeging van zwavelhoudende meststof) werden waterstofconcentraties van 100 ppm gemeten (Timmerman, 2016). Bij bijmengen van zwavelhoudende meststoffen mogen hogere concentraties verwacht worden, waarbij risico op letsel of overlijden bestaat. Bij een toenemend aanbod van zwavelhoudende meststoffen is het geven van voorlichting m.b.t. de veiligheidsrisico's van waterstofsulfide voor verwerkers en eindgebruikers van belang.

Tabel 5.4 Veiligheidsrisico's bij blootstelling aan waterstofsulfide bij toenemende concentraties. ${ }^{1}$

\begin{tabular}{ll} 
Concentratie $\mathrm{H}_{2} \mathrm{~S}$ in ppm & Effecten \\
\hline circa $0,02 \mathrm{ppm}$ & Onaangename geur (rotte eieren) waarneembaar \\
\hline circa $10 \mathrm{ppm}$ & Toenemende mate van penetrante geur \\
\hline$>100 \mathrm{ppm}$ & $\begin{array}{l}\text { Irritatie van de ogen (tranenvloed, roodheid, overgevoeligheid voor licht) en de neus en keel } \\
\text { membranen: verlamming van het geurvermogen }\end{array}$ \\
\hline$>150 \mathrm{ppm}$ & $\begin{array}{l}\text { Irritatie van de ogen (tranenvloed, roodheid, overgevoeligheid voor licht) en de neus en keel } \\
\text { membranen: verlamming van het geurvermogen }\end{array}$ \\
\hline $300-500 \mathrm{ppm}$ & Hoofdpijn, duizeligheid en diarree \\
\hline$>500 \mathrm{ppm}$ & $\begin{array}{l}\text { Gevaar voor longschade, naast ernstige systemische effecten met als mogelijk symptomen: } \\
\text { hoofdpijn, duizeligheid, ataxie, kortademigheid, verminderde bloeddruk en bewusteloosheid }\end{array}$ \\
\hline$>1000 \mathrm{ppm}$ & $\begin{array}{l}\text { Snelle levensbedreigende effecten op het centrale zenuwstelsel en het hart: dodelijk na } \\
\text { inademen langer dan ca. } 30 \text { minuten }\end{array}$ \\
\hline & $\begin{array}{l}\text { Bij de eerste ademteug verlamming van het middenrif, direct bewustzijnsverlies, overlijden } \\
\text { binnen enkele minuten (sudden knock-out, sudden death) }\end{array}$
\end{tabular}

1 Bron: https://www.stigas.nl/agroarbo/bijlagen/gevaren-van-mestgassen/

${ }^{11}$ Bron: Sociaal Economische Raad (SER). https://www.ser.nl/nl/thema/arbeidsomstandigheden/Grenswaarden-gevaarlijkestoffen/Grenswaarden/zwavelwaterstof 


\subsection{Vaste organische meststoffen}

\subsubsection{Samenstelling}

De gemiddelde samenstellingen van de dikke fracties, mestkorrels en de fosfaatarme bodemverbeteraar zijn opgenomen in Tabel 5.5. Alle deelnemende verwerkers produceren een dikke fractie met een drogestofgehalte van circa 30\%, met uitzondering van Ecoson, waar de dikke fractie wordt gedroogd en gekorreld tot een eindproduct met een drogestofgehalte van circa 92\%. GZV produceert twee dikke fracties; de eerste decanter centrifuge levert een dikke fractie die vrij is van polymeer en ijzerzouten en een drogestofgehalte heeft van circa $30 \%$. De twee decanter centrifuge levert met toevoeging van polymeer een dikke fractie met een drogestofgehalte van circa $20 \%$. Ook is voor GZV de samenstelling van de fosfaatarme bodemverbeteraar geproduceerd door het RePeatsysteem opgenomen.

De fosfaatgehalten van de dikke fracties verschillen, wat deels te relateren is aan de verschillen in het fosfaatgehalte van de ingaande mest en het ingaande digestaat. De dikke fracties van de zeefbandpersen hebben alle een vergelijkbare verhouding $\mathrm{N} / \mathrm{P}_{2} \mathrm{O}_{5}(0,8-0,9 \mathrm{~kg} / \mathrm{kg})$. De eerste decanter centrifuge van GZV produceert een dikke fractie met een relatief lage verhouding $\mathrm{N} / \mathrm{P}_{2} \mathrm{O}_{5}(0,5 \mathrm{~kg} / \mathrm{kg})$ en hoog gehalte $\mathrm{P}_{2} \mathrm{O}_{5}(20 \mathrm{~g} / \mathrm{kg})$. De tweede decanter centrifuge produceert een dikke fractie waarin relatief meer stikstof en minder fosfaat wordt afgevangen. De fosfaatarme bodemverbeteraar kenmerkt zich door een laag gehalte $\mathrm{P}_{2} \mathrm{O}_{5}$ t.o.v. de andere dikke fracties. Daardoor kan bij aanwending ervan per $\mathrm{kg}$ fosfaat circa vijfmaal meer organische stof worden opgebracht t.o.v. een niet-behandelde dikke fractie. Circa $40 \%$ van de stikstof is aanwezig als $\mathrm{N}-\mathrm{NH}_{4}$. Voor de mestkorrels van Ecoson is het gehalte $\mathrm{N}-\mathrm{NH}_{4}$ niet bekend, maar naar verwachting lager.

Er zijn verschillen in ijzergehalten. Dikke fracties van verwerkers waar geen ijzer gedoseerd wordt, bevatten $<1 \mathrm{~g} \mathrm{Fe} / \mathrm{kg}$, terwijl de dikke fracties van verwerkers die ijzerzouten toevoegen hogere Fegehalten $(4,8-5,5 \mathrm{~g} / \mathrm{kg})$ hebben. Ook hebben de dikke fracties (en bodemverbeteraar) van bedrijven die ijzersulfaten of zwavelzuur toevoegen hogere zwavelgehalten.

Gehalten aan koper en zink zijn uitgedrukt per kg droge stof om vergelijking met criteria voor ECmeststoffen mogelijk te maken. Gehalten aan koper en zink variëren tussen respectievelijk 176$742 \mathrm{mg} / \mathrm{kg}$ droge stof en 547-2185 mg/kg droge stof voor dikke fracties en mestkorrels. De uitschieter hierbij is de dikke fractie van de tweede decanter centrifuge van GZV; omdat dit concentraat vooral fijne organische stof afvangt, zijn de gehalten aan zware metalen - per kg droge stof - hier hoog t.o.v. de andere stromen. De omvang van deze stroom aan dikke fractie is beperkt. Ook wordt deze stroom afgezet na mengen met MF-concentraat waardoor de koper- en zinkgehalten in het eindproduct weer binnen de range aan normale waarden voor mest en digestaat van covergisting vallen. 


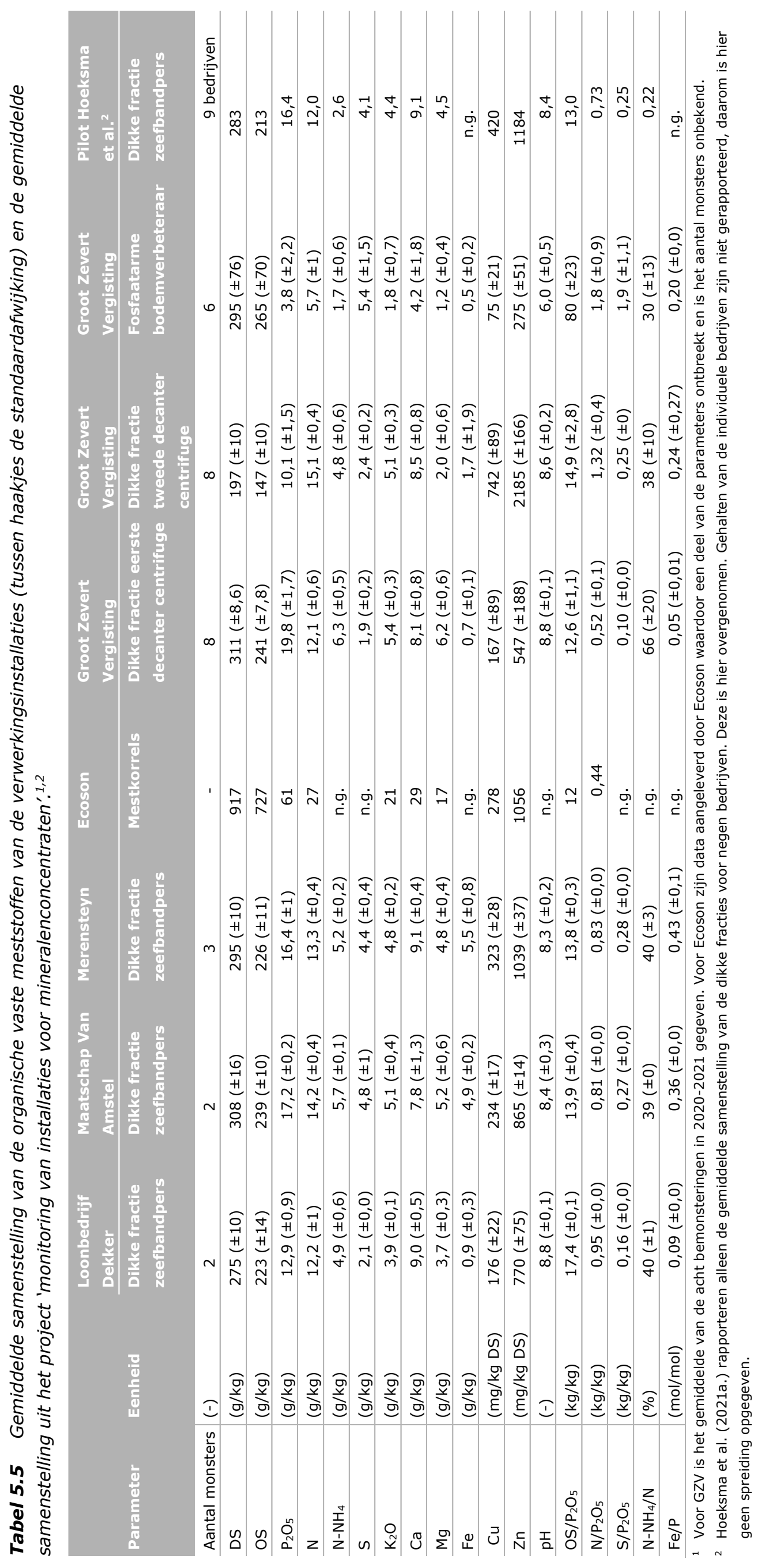




\subsubsection{Criteria bij export en de nieuwe EU-meststoffenverordening}

Dierlijke mest is een categorie 2 materiaal onder de Verordening Dierlijke Bijproducten (EC 1069/2009 en 142/2011) en moet een eindpunt in de productieketen voor dierlijke bijproducten hebben bereikt conform de Uitvoeringsverordening Dierlijke Bijproducten (EC 142/2011) en de verordening EC $1069 / 2009$ voordat export ervan is toegestaan. Het eindpunt dierlijke mest kan bereikt worden als aan een van de volgende criteria is voldaan:

- de mest is gedurende minimaal 60 minuten verhit tot minimaal $70{ }^{\circ} \mathrm{C}$ ('pasteurisatie'); of

- de mest heeft een andere beheerste thermische of chemische behandeling ondergaan waarvan in een speciaal onderzoek ('validatie') is aangetoond dat het ziekteverwekkers in voldoende mate afdoodt.

Het bereiken van het eindpunt dierlijke mest heeft als doel het voorkomen van verspreiding van dierziekten. Wanneer dit eindpunt bereikt is, wordt gesproken over 'verwerkte mest', niet te verwarren met de definitie voor 'mestverwerking' zoals beschreven in de Meststoffenwet. ${ }^{12}$ Met mestverwerking zoals bedoeld in de Meststoffenwet wordt de export of verbranding van dierlijke mest bedoeld. Export van verwerkte mest vindt plaats op basis van wederzijdse erkenning tussen het exporterende en afnemende land. Lidstaten kunnen hierop aanvullende criteria hanteren.

Met de komst van de nieuwe EU Meststoffenwet (EC 2019/1009) komt er de mogelijkheid om verwerkte mest - voor welke het eindpunt in de productieketen voor dierlijke bijproducten is vastgesteld - als grondstof te benutten voor de productie van meststoffen. De EU Meststoffenwet maakt vrije handel in meststoffen in EU27 mogelijk. Nieuw is dat de EU Meststoffenwet is uitgebreid met organische meststoffen. Het betreft een facultatieve wetgeving die op 16 juli 2022 in werking treedt. De EU Meststoffenwet kent Bestandsdelencategorieën (in het Engels: Component Material Categories (CMC's)) waarin criteria worden gesteld aan de grondstoffen van waaruit een meststof mag worden samengesteld welke vervolgens moet voldoen aan een van de Product functie categorieën (Product Function Categories (PFC's).

Dierlijke mest wordt benoemd als grondstof onder CMC 3 (Compost) en CMC 5 (Digestate other than Fresh Crop Digestate), wat inhoudt dat de mest verwerkt tot compost of digestaat tevens een compostering of vergisting heeft ondergaan conform de criteria van de EU Meststoffenwet, waar criteria voor hygiënisatie onderdeel van uitmaken. Daarnaast is CMC 10 (Dierlijke bijproducten) specifiek bedoeld voor dierlijke bijproducten. Hiervan is verwerkte dierlijke mest er een van, op het moment van schrijven zijn er nog geen dierlijke bijproducten met definitieve criteria voor CMC 10 vastgesteld. ${ }^{13}$ Daarmee is vooralsnog onduidelijk of en onder welke voorwaarden bijvoorbeeld een dikke fractie van dierlijke mest onder CMC 10 kan dienen als grondstof voor een meststof met een CEmarkering.

De nieuwe EU Meststoffenwet stelt criteria aan de minimale gehalten van waarde gevende bestanddelen en maximale gehalten aan o.a. zware metalen en pathogenen (Tabel 5.6). Er is nog onduidelijkheid over de toelaatbaarheid van polymeren. Polymeren op basis van polyacrylamide worden veelvuldig gebruikt bij dik-dunscheiding van mest en digestaat. Polyacrylamide is een synthetisch polymeer dat zelf niet giftig is, maar een zeer lage biologische afbreekbaarheid heeft tot kleinere moleculen waarbij kleine hoeveelheden van het monomeer acrylamide kunnen ontstaan. Acrylamide is aangewezen als een zorgwekkende stof (Xiong et al., 2018). ${ }^{14}$ Besluitvorming is nog niet definitief, maar verwacht wordt dat polymeren die volledig biologisch afbreekbaar zijn tot koolstofdioxide en water worden toegestaan in CE-meststoffen. Een aandachtspunt is de beschikbaarheid van polymeren die aan deze criteria kunnen gaan voldoen. Praktijkonderzoek naar biobased polymeren is nog zeer beperkt en de werking blijft veelal achter ten opzichte van synthetische polymeren (Korving et al., 2016). Bij gebruik van dierlijke mest binnen Nederland of export zonder CE-markering (export als zijnde 'dierlijke mest') zijn bovenstaande criteria niet van toepassing.

\footnotetext{
${ }^{12}$ Uitleg definities mestverwerking en verwerkte mest: https://www.nvwa.nl/onderwerpen/mest/mestverwerking-enhygienisatie.

${ }^{13}$ Dagtekening juli 2021.

${ }^{14}$ RIVM Database Stoffen: https://rvszoeksysteem.rivm.nl/stof/detail/235
} 
Tabel 5.6 Grenswaarden voor gehalten aan zware metalen en humaanpathogenen in organische meststof (PFC 1A) onder de EU-meststoffenverordening EC/2019/1009.

\begin{tabular}{|c|c|c|}
\hline Parameter & Eenheid & Grenswaarde \\
\hline $\mathrm{Cd}$ & (mg/kg droge stof) & 1,5 \\
\hline $\mathrm{Cr}(\mathrm{VI})$ & (mg/kg droge stof) & 2,0 \\
\hline $\mathrm{Ni}$ & (mg/kg droge stof) & 50 \\
\hline $\mathrm{Pb}$ & (mg/kg droge stof) & 120 \\
\hline $\mathrm{Cu}$ & (mg/kg droge stof) & 300 \\
\hline $\mathrm{Zn}$ & (mg/kg droge stof) & 800 \\
\hline Salmonella spp. & $(-)$ & Afwezig in $25 \mathrm{~g}$ of $25 \mathrm{ml}$ \\
\hline E. coli of Enterococcus & (aantal bacteriën) & 1000 in $1 \mathrm{~g}$ of $1 \mathrm{ml}$ \\
\hline
\end{tabular}

\subsubsection{Toetsing aan criteria voor zware metalen}

Dierlijke mest bevat hoge gehalten aan koper en zink. Andere zware metalen zijn in deze studie niet geanalyseerd. Er is geen reden om normoverschrijdende gehalten van deze andere metalen te verwachten. Mestscheiding leidt tot een herverdeling van koper en zink over de eindproducten. Dikke fracties bevatten - op drogestofbasis - hogere gehalten aan koper en zink t.o.v. het ingaande digestaat of de ingaande mest, omdat deze metalen zich binden aan organische stof. Er komen overschrijdingen voor t.o.v. de grenswaarde voor CE-gemarkeerde bemestingsproducten. De hoogste gehalten aan koper en zink komen voor in de dikke fractie van de tweede decanter centrifuge van GZV, waar de fijne organische stof wordt afgescheiden. Hoe fijner de organische stof, hoe hoger de bindingscapaciteit voor koper en zink en daarmee ontstaan verschillen in de koper- en zinkgehalten tussen meststromen. De fosfaatarme bodemverbeteraar van GZV kenmerkt zich daarentegen door relatief lage gehalten aan koper en zink (ruim onder de grenswaarde). Dit omdat in het RePeatsysteem, samen met het fosfaat, fijne organische deeltjes uitgespoeld worden en daarna afgevangen worden in het fosfaatprecipitaat dat daardoor hogere gehalten aan koper en zink heeft (paragraaf 5.4).

Op alle verwerkingsinstallaties wordt daarnaast polymeer o.b.v. polyacrylamide toegevoegd wat toepassing van de eindproducten als CE-meststof mogelijk in de weg staat (besluitvorming nog gaande). Bij GZV is de dikke fractie van de eerste decanter centrifuge vrij van polymeer, omdat GZV polymeer doseert voor de tweede decanter centrifuge.

In de eindproducten van GZV zijn in kader van het H2020 project SYSTEMIC ook andere zware metalen geanalyseerd, gerapporteerd en getoetst aan de criteria voor EU-meststoffen (Sigurnjak et al., 2021). Lood, kwik en arseen zijn niet boven de detectiegrens aangetroffen. Nikkel is aangetroffen in digestaat en de dikke fracties in gehalten onder of net boven de criteria voor ECmeststoffen. Samengevat, koper, zink en nikkel kunnen belemmeringen vormen bij de afzet van vaste organische mestproducten uit mest of digestaat onder een CE-markering.

Vanuit een milieukundig perspectief is het relevanter om de totale aanvoer aan zware metalen van alle meststoffen van het bemestingsplan te beoordelen. Dit omdat bijvoorbeeld een fosfaatarme meststof als de bodemverbeteraar van GZV aanvullend op de basisbemesting met dierlijke mest wordt gegeven. Het ontvangende perceel wordt daardoor belast met de som aan zware metalen vanuit dierlijke mest en de bodemverbeteraar. Een dergelijke doorrekening valt buiten dit rapport, maar is opgenomen in Schoumans et al. (2021).

\subsubsection{Evaluatie landbouwkundige kwaliteit}

\section{Dikke fracties en mestkorrels}

Dikke fracties worden vanwege het hoge fosfaatgehalte buiten Nederland afgezet. Voor een verkenning naar de markt voor organische meststoffen in Duitsland en Frankrijk wordt verwezen naar andere rapporten (Van Dijk et al., 2020; Ros et al., 2014). Uit gesprekken met mest- en 
digestaatverwerkers komt naar voren dat dikke fracties gewild zijn in Noord-Frankrijk en de afnemers ook betalen voor afname van de meststof. Er wordt gestuurd op een hoog gehalte aan nutriënten en een klein volume vanwege transportkosten. Dikke fracties kenmerken zich ten opzichte van de dunne fracties door hoge gehalten aan organische stof, hoge fosfaatgehalten en lage verhoudingen $\mathrm{N} / \mathrm{P}_{2} \mathrm{O}_{5}$ en moeten daarom primair als fosfaatmeststof worden gezien. De mestkorrels hebben vergeleken met de dikke fracties de laagste verhouding $\mathrm{N} / \mathrm{P}_{2} \mathrm{O}_{5}$, wat te verklaren is door vervluchtiging van $\mathrm{N}-\mathrm{NH}_{4}$ tijdens het droogproces wat daarna via luchtwassers wordt teruggewonnen.

Dikke fracties van mest- en digestaatverwerkers die ijzerzouten doseren, hebben een verhoogd ijzergehalte $(4,8-5,5 \mathrm{~g} / \mathrm{kg})$ ten opzichte van dikke fracties van verwerkers die geen ijzerzouten doseren $(0,7-1,9 \mathrm{~g} / \mathrm{kg})$. IJzerzouten worden gedoseerd om fosfaat te binden. Daarnaast is het gebruikelijk om bij vergisting van mest ijzer te doseren ter beheersing van het zwavelgehalte in het biogas. GZV en Dekker hebben echter gekozen voor andere methoden om biogas te ontdoen van zwavel en doseren zowel in de vergister als bij de digestaatverwerking geen ijzer. GZV heeft bewust gekozen om geen ijzerzouten toe te voegen, omdat dit de dikke fractie ongeschikt zou maken voor fosfaatverwijdering met het RePeat-systeem. IJzer is een effectief middel om fosfaat te binden, het heeft echter ook een nadelig effect op de plantbeschikbaarheid van fosfaat in de bodem bij gebruik als meststof. In een recente studie werd de makkelijk beschikbare fosfaatfractie bepaald in composten, digestaten en mesten en werd een negatieve correlatie met de verhouding ijzer/fosfaat gevonden (Regelink en Rietra, 2021). IJzer toegevoegd als tweewaardig ijzerzout $\left(\mathrm{FeSO}_{4}, \mathrm{FeCl}_{2}\right)$ precipiteert met fosfaat tot het mineraal vivianiet $\left(\mathrm{Fe}_{3}\left(\mathrm{PO}_{4}\right)_{2} \cdot 8 \mathrm{H}_{2} \mathrm{O}\right)$. In deze vorm is $1,5 \mathrm{~mol}$ ijzer nodig om $1,0 \mathrm{~mol}$ fosfaat te binden. Na blootstelling aan de lucht zal Fe(II) door oxidatie omgezet worden naar Fe(III)hydroxiden. Voor Fe(III)-hydroxiden mag aangenomen worden dat, overeenkomstig grond, de fosfaatbindingscapaciteit $0,5 \mathrm{~mol} P$ per mol Fe bedraagt. Op basis van dit uitgangspunt is berekend hoeveel fosfaat gebonden wordt aan ijzer $\left(\mathrm{P}_{\mathrm{Fe}}\right)$ en dit bedraagt ten hoogste $22 \%$ van het totale fosfaat. Voor de hier geanalyseerde dikke fracties is de invloed van het toegevoegde ijzer op de fosfaatbeschikbaarheid daarmee naar verwachting beperkt, omdat ten hoogste $22 \%$ van het fosfaat gebonden wordt.

\subsubsection{Evaluatie fosfaatarme bodemverbeteraar}

GZV behandelt een deel van de dikke fractie van de eerste decanter centrifuge verder met het RePeatsysteem waar fosfaat wordt verwijderd door de dikke fractie te spoelen met proceswater en zwavelzuur. Het fosfaatgehalte neemt hierdoor af van circa $19 \mathrm{~g} / \mathrm{kg}$ tot $4 \mathrm{~g} \mathrm{P}_{2} \mathrm{O}_{5} / \mathrm{kg}$ en de verhouding organische stof $/ \mathrm{P}_{2} \mathrm{O}_{5}$ neemt toe van 13 tot circa $80 \mathrm{~kg} / \mathrm{kg}$. Uit de praktijk blijkt dat er een markt is voor bodemverbeterende producten uit mest, mits het fosfaatgehalte dusdanig is verlaagd dat de ratio tussen organische stof en fosfaat vergelijkbaar is met die van compost. Door het spoelen met zuur water heeft de bodemverbeteraar een verlaagd stikstof- en kaligehalte en een verhoogd zwavelgehalte ten opzichte van de ingaande dikke fractie. Verwacht mag worden dat het zwavelgehalte voor een groot deel aanwezig is in de vorm van het goed oplosbare sulfaat $\left(\mathrm{SO}_{4}{ }^{2-}\right)$. Vooralsnog wordt het sulfaat er niet extra uitgewassen en/of teruggewonnen als gips $\left(\mathrm{CaSO}_{4} \cdot 2 \mathrm{H}_{2} \mathrm{O}\right)$.

De bodemverbeteraar is een product geproduceerd uit dierlijke mest en de stikstof die het bevat, telt daarom mee voor de gebruiksnorm dierlijke mest. Het fosfaat dat het bevat, telt mee voor de fosfaatgebruiksnorm. GZV heeft een ontheffing gekregen om fosfaat in de bodemverbeteraar voor $50 \%$ vrij te stellen van de fosfaatgebruiksnorm. Het betreft een tijdelijke ontheffing in het kader van een pilotproject en met een beperkt aantal afnemende boeren. GZV zet de bodemverbeteraar af op zandgronden in de omgeving Haarlo/Eibergen. Tabel 5.7 toont een voorbeeld van een bemestingsscenario op bouwland, bestaande uit een basisgift van 20 ton runderdrijfmest, aangevuld met 14 ton bodemverbeteraar waarbij de fosfaatvrije voet van $50 \%$ is toegepast. Ter vergelijking is ook een bemestingsscenario opgenomen met gft-compost. De gekozen doseringen passen binnen de fosfaatgebruiksnorm voor bouwland met een neutrale fosfaattoestand ( $70 \mathrm{~kg} \mathrm{P}_{2} \mathrm{O}_{5} / \mathrm{ha}$ ) en de gebruiksnorm dierlijke mest (170 kg N/ha, geen derogatie). In het scenario met de bodemverbeteraar is de gebruiksnorm dierlijke mest de eerste beperkende factor voor de hoeveelheid aan te wenden bodemverbeteraar. Met 14 ton bodemverbeteraar wordt circa 3,7 ton organische stof aangevoerd, 
waarvan 2,6 ton effectieve organische stof (EOS) $)^{15}$ berekend met een humificatie-coëfficiënt van $70 \%$ (Regelink et al., 2019). Tevens wordt met de bodemverbeteraar $76 \mathrm{~kg} \mathrm{~S} / \mathrm{ha}$ aangevoerd, boven op de zwavel uit de runderdrijfmest, waardoor de zwavelopname van gangbare akkerbouwgewassen fors wordt overschreden. Op zandgronden bedraagt het zwavelbemestingsadvies respectievelijk 0 en $10 \mathrm{~kg}$ $\mathrm{S} /$ ha voor gewassen met een lage (pootaardappel, suikerbiet) en matige zwavelbehoefte (o.a. aardappel en snijmais). Aanbevolen wordt om het zwavelgehalte van de bodemverbeteraar door spoelen te verlagen om te voorkomen dat de zwavelgift de gewasbehoefte overschrijdt.

In het scenario met gft-compost wordt de gebruiksnorm fosfaat volledig opgevuld, omdat de gebruiksnorm dierlijke mest nu niet beperkend is (stikstof uit gft-compost telt niet mee voor de gebruiksnorm dierlijke mest). Mede hierdoor is de aanvoer van organische stof iets hoger $(4,0$ ton/ha) dan in het scenario met de bodemverbeteraar. Het gebruik van gft-compost leidt ook tot een hogere aanvoer van EOS (3,6 ton EOS/ha), omdat gft-compost een hogere humificatie-coëfficiënt kent van $90 \%$. De aanvoer van koper en zink is, met name voor zink, lager bij gebruik van de bodemverbeteraar vergeleken met de aanvoer via een gemiddeld gft-compost, maar hoog ten opzichte van de aanvoer bij bemesting met alleen runderdrijfmest. Een verdere beoordeling van de milieukundige effecten van de aanvoer aan zware metalen was geen onderdeel van dit project, maar is elders gerapporteerd (Schoumans et al., 2021).

Tabel 5.7 Voorbeeld bemestingsscenario bij gebruik van runderdriffmest (RDM), aangevuld met 'Groene effectieve bodemverbeteraar' (GEB) of gft-compost op bouwland bij een neutrale fosfaattoestand ( $70 \mathrm{~kg} \mathrm{P}_{2} \mathrm{O}_{5} / \mathrm{ha}$ ) en een gebruiksnorm dierlijke mest van $170 \mathrm{~kg} \mathrm{~N} / \mathrm{ha}$ (geen derogatie). ${ }^{1}$

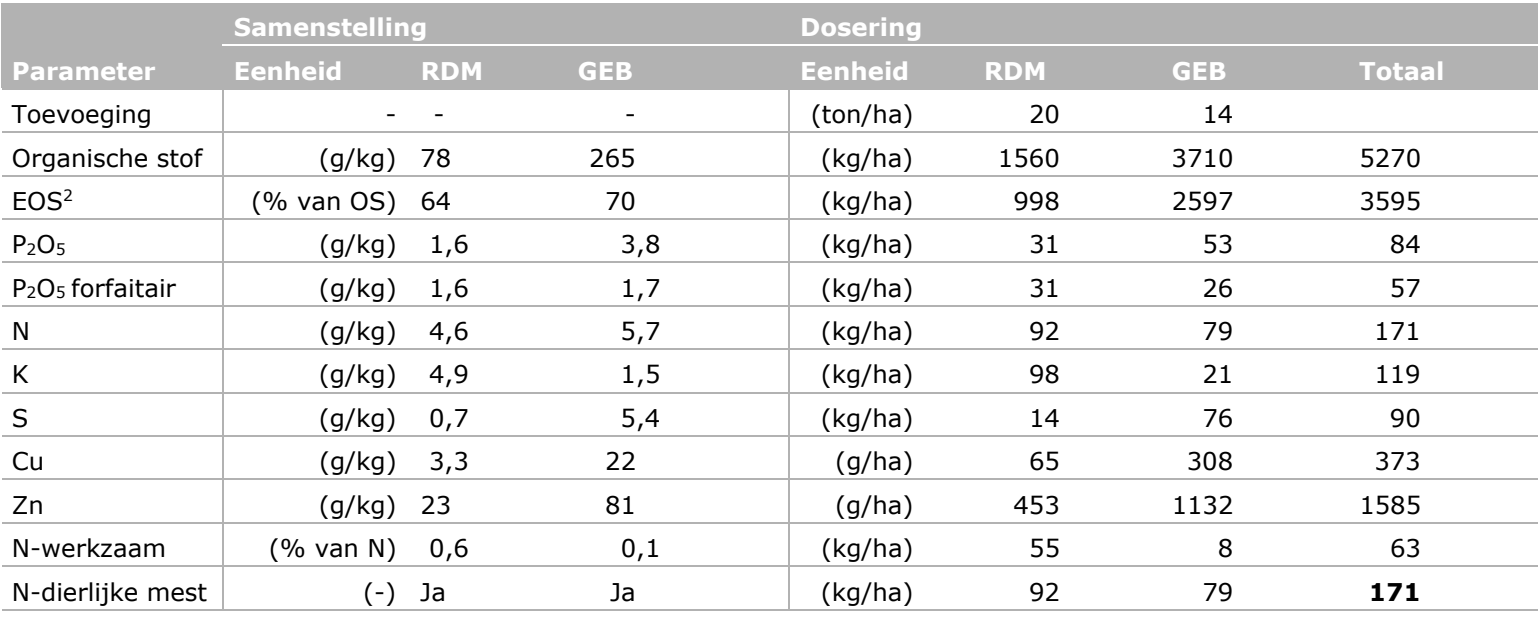

\begin{tabular}{|c|c|c|c|c|c|c|c|}
\hline Parameter & Eenheid & RDM & gft-compost ${ }^{3}$ & Eenheid & RDM & gft-compost & Totaal \\
\hline Toevoeging & - & - & - & (ton/ha) & 20 & 15 & \\
\hline Organische stof & $(\mathrm{g} / \mathrm{kg})$ & 78 & 270 & (kg/ha) & 1560 & 4050 & 5610 \\
\hline $\mathrm{P}_{2} \mathrm{O}_{5}$ & $(\mathrm{~g} / \mathrm{kg})$ & 1,6 & 5,3 & (kg/ha) & 31 & 80 & 111 \\
\hline $\mathrm{P}_{2} \mathrm{O}_{5}$ forfaitair & $(\mathrm{g} / \mathrm{kg})$ & 1,6 & 2,8 & (kg/ha) & 31 & 40 & 71 \\
\hline K & $(\mathrm{g} / \mathrm{kg})$ & 4,9 & 7,0 & (kg/ha) & 98 & 105 & 203 \\
\hline $\mathrm{S}$ & $(\mathrm{g} / \mathrm{kg})$ & 0,7 & 2,3 & (kg/ha) & 14 & 34 & 48 \\
\hline $\mathrm{Cu}$ & $(\mathrm{g} / \mathrm{kg})$ & 3,3 & 30 & (g/ha) & 65 & 450 & 515 \\
\hline $\mathrm{Zn}$ & $(\mathrm{g} / \mathrm{kg})$ & 23 & 143 & (g/ha) & 453 & 2145 & 2598 \\
\hline
\end{tabular}

1 GZV heeft een tijdelijke ontheffing gekregen om de GEB, op een beperkt areaal, toe te passen met een fosfaatvrije voet van $50 \%$ en een stikstofwerkingscoëfficiënt van $10 \%$, met deze voorwaarden is gerekend.

2 EOS (effectieve organische stof): het aandeel van de toegevoegde organische stof (OS) dat één jaar na toevoeging nog aanwezig is in de bodem. Bron EOS-waarden: (Regelink et al., 2019, Rietra et al., 2021).

3 Samenstelling op basis van eigen data voor zes representatieve gft-composten bemonsterd in 2020.

\footnotetext{
${ }^{15}$ Effectieve organische stof is gedefinieerd als organische stof die één jaar na toevoeging nog aanwezig is in de bodem.
} 


\subsubsection{Veenvervanger uit digestaat}

De bodemverbeteraar geproduceerd door het RePeat-systeem van GZV leent zich ook voor meer hoogwaardige toepassingen, waaronder als veenvervanger voor substraat in de glastuinbouw, potgrond voor de consumentensector of als veenvervanger in dekaarde voor substraat in de champignonteelt. Perspectieven voor deze afzetroutes zijn verkend binnen het H2020-project SYSTEMIC, waaruit blijkt dat de bodemverbeteraar aan de minimale productcriteria kan voldoen. Voor toepassing in potgrond is een extra spoelstap nodig om het zoutgehalte te verlagen, maar voor toepassing in de champignonteelt is een hoog zwavelgehalte geen belemmering. De ontwikkeling van afzetroutes naar bovengenoemde markten wordt voortgezet in het TKI PPS-project BIOVALOR, gestart in 2021.

\section{$5.4 \quad$ Fosfaatprecipitaat}

GZV behandelt de fosfaatrijke dikke fractie van het digestaat verder met het RePeat-systeem waarin fosfaat separaat wordt terugwonnen door een behandeling met achtereenvolgens zuur en base. Het doel hiervan is om fosfaat terug te winnen als product met een hoog drogestofgehalte, zodat dit geschikt is als grondstof voor de productie van organische mestkorrels. Uit contacten met potentiële afnemers in de meststoffenindustrie blijkt dat er geen interesse is in de afname van fosfaatprecipitaat in de vorm van een slib, omdat deze afnemers niet ingesteld zijn op het werken met verpompbare producten en niet beschikken over drooginstallaties. Momenteel loopt een onderzoek (TKI PPS-project BIOVALOR) om het geproduceerde calciumfosfaatslib beter te ontwateren dan wel over te stappen op de productie van struviet, wat veel makkelijker ontwatert.

Tabel 5.8 toont de gemiddelde samenstelling van het fosfaatprecipitaat van het RePeat-systeem van GZV, gebaseerd op monsters genomen in acht rondes tussen november 2020 en april 2021. In die monitoringsperiode doseerde GZV kalkmelk voor de precipitatie van fosfaat, waardoor een calciumfosfaatslib ontstaat met een hoog organischestofgehalte. Calcium zorgt voor het uitvlokken van organische stof. Dit verklaart, vanwege het waterbindend vermogen van organische stof, het relatief lage drogestofgehalte $(140 \mathrm{~g} / \mathrm{kg})$ en het hoge organischestofgehalte $(50 \mathrm{~g} / \mathrm{kg})$ van het fosfaatprecipitaat zoals geproduceerd in de monitoringsperiode. Het fosfaatgehalte van het slib was gemiddeld $17 \mathrm{~g} \mathrm{P}_{2} \mathrm{O}_{5} / \mathrm{kg}$ en is daarmee vergelijkbaar met het fosfaatgehalte van de ingaande dikke fractie $\left(20 \mathrm{~g} \mathrm{P}_{2} \mathrm{O}_{5} / \mathrm{kg}\right.$ ). Op drogestofbasis is het fosfaatgehalte in het slib twee keer hoger dan in de ingaande dikke fractie (circa 120 t.o.v. $60 \mathrm{~g} \mathrm{P} \mathrm{P}_{5} / \mathrm{kg}$ ), waaruit volgt dat verdere ontwatering een noodzaak is om een voordeel qua transportkosten te realiseren. Een andere optie is om over te schakelen naar toevoeging van magnesiumhydroxide i.p.v. kalkmelk waardoor struviet gevormd wordt dat beter ontwaterbaar is dan calciumfosfaat en waarbij minder organische stof uitzakt. De werking hiervan is eerder aangetoond in labproeven (Regelink et al., 2019). Echter, de kosten voor het gebruik van magnesiumhydroxide zijn aanzienlijk hoger dan voor calciumhydroxide en GZV heeft zorgen over het risico op neerslag van struviet in de leidingen van het RePeat-systeem bij toevoeging van magnesium. Het fosfaatprecipitaat heeft een hoog zwavelgehalte doordat ook precipitatie van gips $\left(\mathrm{CaSO}_{4} \cdot 2 \mathrm{H}_{2} \mathrm{O}\right)$ plaatsvindt. Een fosfaat/gips-meststof is een gangbare meststof. Het is echter wel van belang om het fosfaatprecipitaat verder te ontwateren om te voorkomen dat de meststof zuurstofloos wordt en sulfaat wordt omgezet naar sulfide. Sulfidevorming is ongewenst, omdat dit leidt tot een verhoogd risico op emissie van het giftige waterstofsulfide tijdens de naverwerking, opslag, transport of aanwending. GZV heeft als voorzorgsmaatregel een aantal tanks van het RePeat-systeem voorzien van continue beluchting. Ook is extra luchtafzuiging geplaatst op de installaties die een risico hebben op emissies van waterstofsulfide.

Het fosfaatprecipitaat zoals het in 2020 werd geproduceerd, voldoet nog niet aan de doelstelling om een fosfaatmeststof met een hoog drogestofgehalte te produceren. Het fosfaatprecipitaat werd afgezet naar akkerbouwers in Nederland. 
Tabel 5.8 Gemiddelde samenstelling van het fosfaatprecipitaat van het RePeat-systeem van Groot Zevert Vergisting met tussen haakjes de standaarddeviatie. ${ }^{1}$

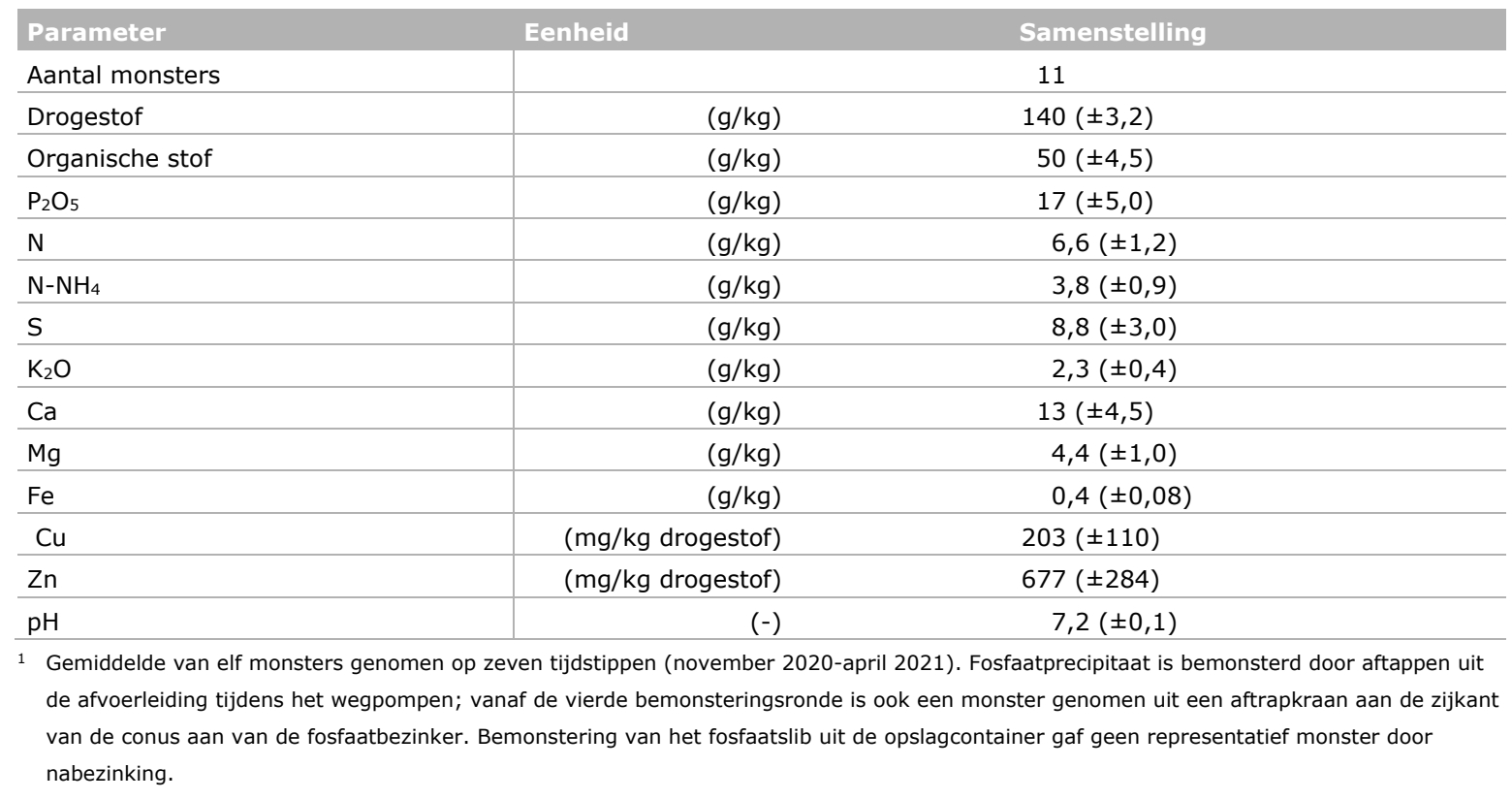

\subsection{Loosbare effluenten}

\subsubsection{Prestatiekenmerken}

De verwerkers met een RO-installatie zetten een deel van de mest of het digestaat om in loosbaar water waardoor het volume af te voeren mest of digestaat afneemt. Het permeaat van de ROinstallatie wordt hiervoor nabehandeld door een ionenwisselaar waarna het effluent ervan geloosd wordt op het oppervlaktewater. Lozingscriteria voor effluenten van verwerkers worden vastgesteld door het lokale bevoegd gezag (het waterschap) op basis van locatiespecifieke waterkwaliteitsdoelstellingen. Daarom kunnen lozingscriteria verschillen per verwerker.

Vanwege de behoefte aan inzicht in de prestatiekenmerken van RO-installaties en de samenstelling van door mestverwerkers geloosde effluenten is in 2019-2020 de werkgroep 'Harmonisatie lozingenbeleid mestverwerkingsinstallaties' opgericht. Deze werkgroep heeft een meetcampagne uitgevoerd naar de geloosde effluenten van verwerkers qua chemische samenstelling en qua zogenoemde voorzorgparameters, zoals antibioticaresistente bacteriën, pathogenen en medicijnresten (Hoeksma et al., 2021b). Qua bedrijven met een RO-installatie en nageschakelde ionenwisselaar zijn twee verwerkers van varkensdrijfmest en een verwerker van digestaat van co-vergisting meegenomen. De meetcampagne heeft o.a. geleid tot prestatiekenmerken voor de chemische samenstelling van geloosde effluenten van verwerkers met een RO-installatie en nageschakelde ionenwisselaar, opgenomen in Tabel 5.9. Het doel van de getoonde prestatiekenmerken is alleen om te kunnen beoordelen of de verwerkingsinstallatie naar behoren functioneert. Waterschappen kunnen lagere lozingsnormen of aanvullende criteria hanteren.

\subsubsection{Samenstelling en toetsing}

Tabel 5.9 toont de samenstelling van de loosbare effluenten van GZV, Van Amstel en Merensteyn en de door Hoeksma et al. (2021b) gerapporteerde prestatiekenmerken voor de samenstelling van geloosde effluenten van verwerkers met een RO-installatie en nageschakelde ionenwisselaar. Fosfaat ligt bij alle drie de verwerkers onder de kwantificeringslimiet van 0,02 mg/L. Voor stikstof zijn er verschillen, het effluent van GZV heeft het laagste gehalte en het effluent van Merensteyn het hoogste gehalte. De drie verwerkers hebben geen overschrijdingen ten opzichte van de prestatiekenmerken. 
Het loosbare effluent van GZV is ook twee keer geanalyseerd op een breed pakket aan residuen van herbiciden, pesticiden, veterinaire geneesmiddelen en pathogenen. De resultaten hiervan zijn elders gerapporteerd (Sigurnjak et al., 2021). Het effluent van GZV is vrij van pathogenen (E. coli en Salmonella) en er zijn geen residuen van herbiciden, pesticiden of diergeneesmiddelen boven de kwantificeringslimiet van $10 \mu \mathrm{g} / \mathrm{kg}$ gemeten. Dit is in overeenstemming met eerdere bevindingen van Hoeksma et al. (2021b) voor effluenten van mestverwerkingsinstallaties.

Tabel 5.9 Gemiddelde samenstelling van de geloosde effluenten (na ionenwisselaar) van de verwerkingsinstallaties van Groot Zevert Vergisting, Maatschap Van Amstel en Merensteyn en de prestatiekenmerken voor de samenstelling van geloosde effluenten van verwerkers met een omgekeerde osmose-installatie en nageschakelde ionenwisselaar, met tussen haakjes de standaardafwijking.

\begin{tabular}{|c|c|c|c|c|c|}
\hline Parameter & Eenheid & $\begin{array}{l}\text { Groot Zevert } \\
\text { Vergisting }\end{array}$ & $\begin{array}{l}\text { Maatschap } \\
\text { Van Amstel }\end{array}$ & Merensteyn & $\begin{array}{l}\text { Prestatiekenmerken } \\
\text { Hoeksma et al. }{ }^{2}\end{array}$ \\
\hline Aantal monsters & $(-)$ & 7 & 3 & 3 & - \\
\hline $\mathrm{pH}$ & $(-)$ & $5,6( \pm 1,19)$ & $5,8( \pm 1,0)$ & $5,6( \pm 0,8)$ & $5-9$ \\
\hline Elektrische geleidbaarheid & $(\mathrm{mS} / \mathrm{cm})$ & $0,042( \pm 0.08)$ & $0,03( \pm 0.03)$ & $0,15( \pm 0.02)$ & 0,4 \\
\hline $\mathrm{N}$ & $(\mathrm{mg} / \mathrm{l})$ & $0,3( \pm 0,1)$ & $4,4( \pm 3,9)$ & $9,8( \pm 2,5)$ & 15 \\
\hline $\mathrm{N}-\mathrm{NH}_{4}$ & $(\mathrm{mg} / \mathrm{l})$ & $0,2( \pm 0,1)$ & $4,3( \pm 3,9)$ & $9,8( \pm 2,5)$ & 16 \\
\hline $\mathrm{N}-\left(\mathrm{NO}_{2}+\mathrm{NO}_{3}\right)$ & $(\mathrm{mg} / \mathrm{l})$ & $<0,03$ & $<0,03$ & $<0,03$ & 0,5 \\
\hline $\mathrm{Cl}$ & $(\mathrm{mg} / \mathrm{l})$ & $<0,6$ & $1,1( \pm 1,0)$ & $<0,6$ & 50 \\
\hline $\mathrm{Na}$ & $(\mathrm{mg} / \mathrm{l})$ & $0,5( \pm 0,6)$ & $0,3( \pm 0,3)$ & $0,4( \pm 0,1)$ & n.b \\
\hline Biochemisch zuurstofverbruik (BZV) & $(\mathrm{mg} / \mathrm{l})$ & n.g. & n.g. & n.g. & 2 \\
\hline Chemisch zuurstofverbruik (CZV) & $(\mathrm{mg} / \mathrm{l})$ & n.g. & n.g. & n.g. & 5 \\
\hline Onopgeloste stoffen & $(\mathrm{mg} / \mathrm{l})$ & n.g. & n.g. & n.g. & $<5$ \\
\hline
\end{tabular}

1 n.g.: niet geanalyseerd, n.b.: voor deze parameter is geen prestatiekenmerk bepaald.

2 Door Hoeksma et al. (2021b) gerapporteerde prestatiekenmerken gebaseerd op metingen van het geloosde effluent van twee verwerkers van varkensdrijfmest met een omgekeerde osmose-installatie en na-geschakelde ionenwisselaar en een verwerker van digestaat van co-vergisting met een omgekeerde osmose-installatie en na-geschakelde ionenwisselaar.

\subsection{Conclusies producten}

Alle NK-concentraten van de bemonsterde verwerkers voldoen aan de door het JRC voorgestelde definitie voor RENURE-producten en aan de voorgestelde RENURE-criteria $\left(\mathrm{N}-\mathrm{NH}_{4}+\mathrm{N}-\mathrm{NO}_{3}\right) / \mathrm{N} \geq 90 \%$ en TOC/N $\leq 3,0$ ) en komen daarmee in aanmerking voor gebruik als kunstmestvervanger indien deze criteria in de Europese wetgeving wordt opgenomen. Het gemiddelde zwavelgehalte in het NKconcentraat varieert tussen 1,7 en $5,4 \mathrm{~g} / \mathrm{kg}$ voor de verschillende verwerkers. De chemietoevoeging (zwavelzuur en ijzersulfaat) in het verwerkingsproces is bepalend voor de hoogte van het zwavelgehalte van de eindproducten. Bij gebruik van NK-concentraat als kunstmestvervanger zijn hoge zwavelgehalten ongewenst, omdat de basisbemesting met drijfmest al voorziet in de gewasbehoefte aan zwavel. Een zwavelgift die hoger is dan de gewasopname geeft risico's op uitspoeling van sulfaat en lagere opname van sporenelementen door het gewas. Door blenden kan een meststof op maat gemaakt worden. Het is echter af te raden om NK-concentraat met drijfmest te mengen voorafgaand aan opslag vanwege risico's op emissies van het giftige waterstofsulfide. Toevoeging van ijzersulfaat zorgt voor een nagenoeg volledige verwijdering van fosfaat $\left(\mathrm{P}_{2} \mathrm{O}_{5}\right.$-gehalte $<0,1 \mathrm{~g} / \mathrm{kg}$ in het NK-concentraat), maar draagt echter ook bij aan het verhogen van het zwavelgehalte van het NK-concentraat.

De dikke fracties van de bemonsterde verwerkers hebben een drogestofgehalte van circa $30 \%$, ongeacht de scheidingstechniek (zeefbandpers of decanter centrifuge). Er zijn verschillen in het 
fosfaatgehalte $\left(13-19 \mathrm{~g} \mathrm{P}_{2} \mathrm{O}_{5} / \mathrm{kg}\right.$ ) van de dikke fracties, wat deels komt door verschillen in het fosfaatgehalte van de ingaande mest en het ingaande digestaat. Ecoson droogt en perst de dikke fractie tot een drogestofgehalte van $92 \%$. De dikke fracties hebben een lage verhouding $\mathrm{N} / \mathrm{P}_{2} \mathrm{O}_{5}$ en zijn primair fosfaatmeststoffen. IJzer komt in verhoogde gehalten voor in dikke fracties van installaties waar ijzerzouten worden gedoseerd maar het aandeel aan ijzer gebonden fosfaat is met - naar schatting - $20 \%$ van totaal fosfaat beperkt. De dikke fracties worden naar het buitenland afgezet als 'dierlijke mest'. Onder de nieuwe EU-meststoffenwetgeving ontstaan er mogelijkheden voor verhandeling met een CE-markering. Aandachtspunten daarbij zijn gehalten aan koper, zink (mest) en nikkel (bij co-vergisting) in dikke fracties t.o.v. de criteria voor CE-meststoffen en het gebruik van polymeer o.b.v. polyacrylamide. Door deze knelpunten lijken de perspectieven voor verhandeling van dikke fracties als (grondstof voor) CE-meststof op dit moment beperkt.

De fosfaatverarmde bodemverbeteraar van GZV heeft een vijfmaal hogere ratio tussen organische stof en fosfaat dan de dikke fracties. Door het spoelproces (met zwavelzuur) zijn het stikstof- en kaliumgehalte verlaagd en het zwavelgehalte verhoogd t.o.v. de ingaande dikke fractie van digestaat. Aanbevolen wordt om het zwavelgehalte van de bodemverbeteraar door spoelen te verlagen om te voorkomen dat de zwavelgift de gewasbehoefte overschrijdt. Er zijn zeer goede perspectieven voor afzet van de bodemverbeteraar als veenvervanger, bijvoorbeeld in dekaarde in de champignonteelt, waarbij de marktwaarde hoger is dan bij afzet naar open teelten in de landbouw en het product tevens het hele jaar door kan worden afgezet.

Het fosfaatprecipitaat van het RePeat-systeem van GZV heeft een laag drogestofgehalte waardoor er nauwelijks sprake is van een indikking ten opzichte van de ingaande dikke fractie van digestaat. Een verdere indikkingsstap of drogen van het fosfaatprecipitaat is daarom nodig om een voordeel op de transportkosten te realiseren. Het fosfaatprecipitaat bevat naast fosfaat hoge gehalten aan organische stof en gips (calciumsulfaat), waardoor er een verhoogd risico is op vorming van waterstofsulfide tijdens het productieproces en de opslag. GZV heeft als voorzorgsmaatregel een aantal tanks voorzien van continue beluchting. Ook is extra luchtafzuiging geplaatst op de installaties die een risico hebben op emissies van waterstofsulfide.

De loosbare effluenten van de drie onderzochte verwerkers voldoen aan de prestatiekenmerken voor loosbare effluenten zoals opgesteld door Hoeksma et al. (2021b). Fosfaatconcentraties zijn voor alle drie de verwerkers beneden de kwantificeringslimiet, terwijl de hoogte van de stikstofconcentratie in het effluent tussen de verwerkers verschilt van 0,3 tot 9,8 mg N/L. 


\section{Kosten}

\section{$6.1 \quad$ Inleiding}

Mestverwerking is ontstaan als oplossing voor de verwerking van het mestoverschot. Om voldoende mestverwerkingscapaciteit te realiseren, is in 2014 de verplichte mestverwerking ingevoerd. Nietgrondgebonden veehouders - waarbij de fosfaatuitscheiding hoger is dan de plaatsingsruimte binnen het bedrijf - zijn verplicht om een deel ${ }^{16}$ van het overschot aan fosfaat te laten 'verwerken'. De veehouder kan voldoen aan de verwerkingsplicht door de mest te exporten, af te zetten naar een mestverwerker die de fosfaat exporteert (driepartijenovereenkomst) of door aankoop van Vervangende verwerkingsovereenkomsten (VVO's). De sturende factor voor verwerking van dierlijke mest voor een afzonderlijke veehouder is het fosfaatoverschot - en in mindere mate het stikstofoverschot - binnen de Nederlandse landbouw.

Een positieve businesscase is een voorwaarde om mestverwerking tot stand te laten komen. Nieuwe initiatieven voor mestverwerkingsinstallaties komen vaak moeilijk van de grond en ook bestaande bedrijven moeten continu meebewegen met veranderingen in de mestmarkt, wet- en regelgeving en de maatschappelijke aandacht. De poorttarieven staan onder druk door dalende afzetkosten voor de afzet van onbewerkte (gehygiëniseerde) drijfmest op de binnenlandse markt als gevolg van de daling in de fosfaatproductie door landbouwdieren in Nederland in de periode 2016-2020 (hoofdstuk 8). Omdat de verplichte mestverwerking voor veehouders alleen is gebaseerd op het overschot aan fosfaat, loopt het aanbod te verwerken mest terug en is de waarde van de VVO's in 2020 gedaald tot een nieuw minimum. Sinds 2016 wordt er meer fosfaat via export of verwerking buiten de (Nederlandse) landbouw geplaatst dan vanuit de verplichting tot mestverwerking noodzakelijk is (NCM, 2020). Ondertussen stijgt de verwerkingscapaciteit voor varkensdrijfmest in 2020/2021 (NCM, 2020). Deze groei past bij de ambitie vanuit het ministerie van LNV om meer mest te laten verwerken door een verplichting voor veehouders om ofwel alle mest volledig te verwerken, ofwel alle mest af te zetten op eigen grond, ofwel via langlopende contracten met grondeigenaren. ${ }^{17}$ Echter, om ook in de nabije toekomst een duurzame ontwikkeling van de mestverwerkingssector te creëren, is perspectief op een gunstige businesscase en een zekere aanvoer van mest naar verwerkers noodzakelijk. Om deze discussie te voeren, is inzicht nodig in de huidige kosten en baten van mestverwerkers en toekomstige veranderingen daarin.

In dit hoofdstuk wordt op basis van gesprekken met de verwerkers en overige beschikbare informatie een berekening gegeven voor de volgende kostenposten:

- Opslag, transport en afzet van de eindproducten

- Gebruik van chemie

- Energieverbruik (elektriciteit, gas, restwarmte)

- Investerings- en afschrijvingskosten van installaties

- Bedrijfsvoering (onderhoud, personeel)

De kostenanalyse is generiek opgezet en maakt gebruik van gemiddelde kosten; de kostenanalyse is daarmee niet representatief voor een individuele verwerker - waarvoor de businesscase samenhangt met locatie- en regiospecifieke condities -, maar geeft een algemeen beeld van de opbouw van het poorttarief voor mestverwerking.

\footnotetext{
${ }^{16}$ Het percentage te verwerken mest varieert per regio: in 2020 en 2021 bedraagt de verplichte mestverwerking in regio Zuid 52\%, in regio Oost 59\% en in de overige regio's 10\% van het bedrijfsoverschot aan fosfaat.

${ }^{17}$ Ministerie van LNV - Contouren nieuw mestbeleid, 8 september 2020. Kenmerk: DGA-PAV / 20230798
} 


\subsection{Uitgangspunten}

\subsubsection{Scenario's voor verwerking van varkensdrijfmest}

Kosten zijn berekend voor drie gangbare scenario's voor verwerking van varkensdrijfmest en afzet van eindproducten. Tabel 6.1 toont deze scenario's. Er is onderscheid gemaakt tussen mestverwerking en monomestvergisting gevolgd door digestaatverwerking. De scenario's zijn opgesteld voor gangbare scheidingstechnieken (dik-dunscheiding en opwerking tot NK-concentraat). Scenario A is gebaseerd op de mestverwerking bij Dekker. Er is onderscheid gemaakt in A1 en A2 waarbij een verschillende transportafstand voor de afzet van de dunne fractie is gehanteerd. Scenario B is gebaseerd op het mestverwerkingsproces zoals toegepast bij Van Amstel en Merensteyn. Varkensdrijfmest wordt gescheiden in een dikke fractie en NK-concentraat welke in de regio wordt afgezet als kunstmestvervanger. Er is aangenomen dat het NK-concentraat niet wordt geblend en dat de dikke fractie met aardgas wordt geblend. Scenario $C$ is gebaseerd op het verwerkingsproces van GZV waarbij co-vergiste mest (digestaat) wordt gescheiden. De businesscase van de vergistingsinstallatie is echter geen onderdeel van de kostenberekening; alleen de kosten voor de verwerking en afzet van het digestaat zijn meegenomen. Er is restwarmte beschikbaar voor de hygiënisatie en het NKconcentraat wordt na blenden afgezet in de regio als kunstmestvervanger.

Tabel 6.1 Omschrijving scenario's voor de kostenberekening voor verwerking van varkensdrijfmest.

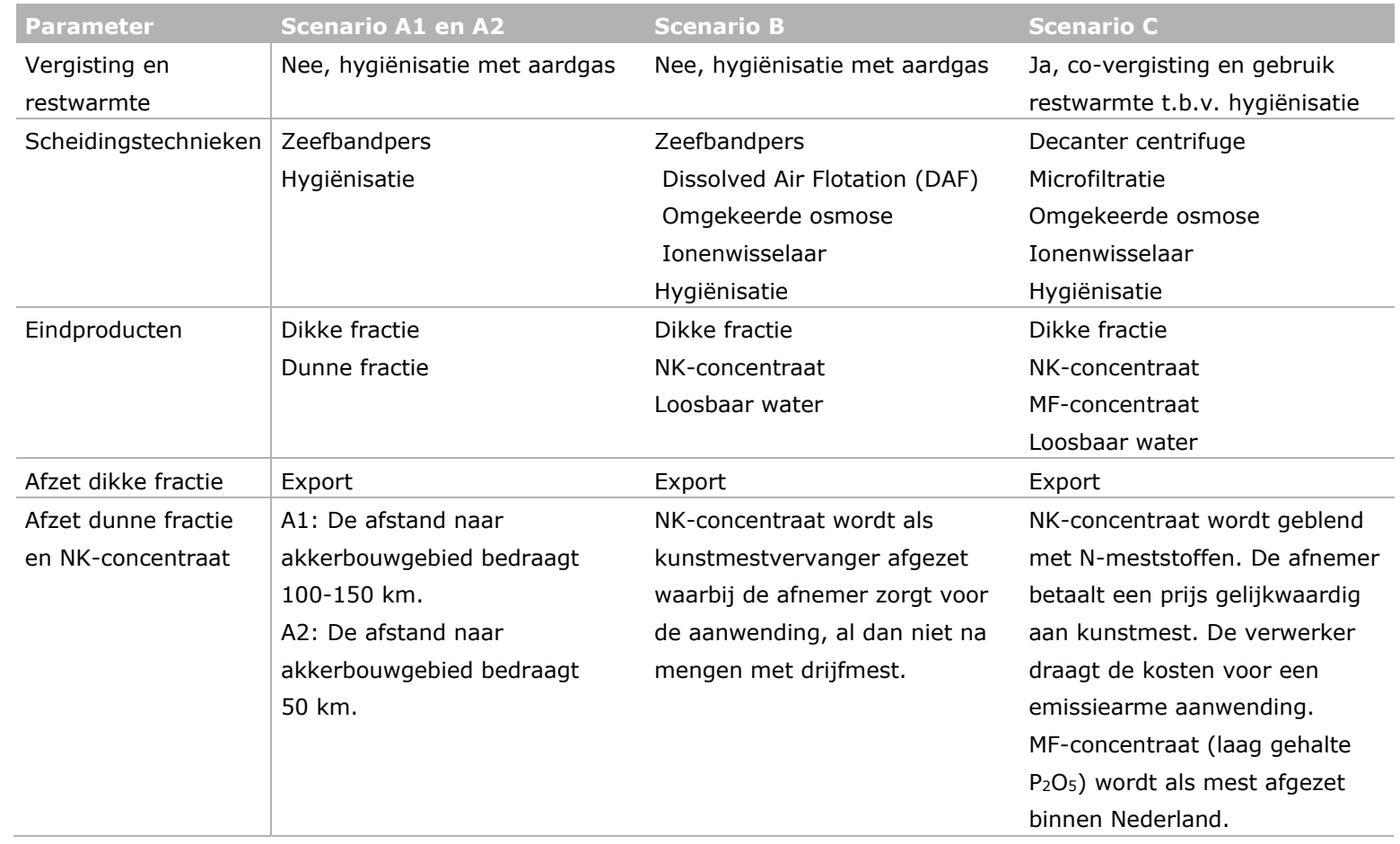

\subsubsection{Massabalans en energie- en chemieverbruik van de verwerkingsinstallaties}

De uitgangspunten voor de massabalansen en het chemie- en energieverbruik van de verwerkingsinstallaties voor de drie scenario's zijn samengevat in Tabel 6.2. Massabalansen zijn overgenomen uit hoofdstuk 3 . Het energie- en chemieverbruik van de installaties zijn grotendeels gebaseerd op door de verwerkers aangeleverde informatie en - indien niet volledig - aangevuld met geschatte waarden. Qua chemieverbruik zijn de meest gebruikte stoffen meegenomen, waaronder polymeer (dik-dunscheiding), zwavelzuur (RO-installatie) en ijzersulfaat (fosfaatverwijdering). Waar mogelijk is het gemiddelde van meerdere verwerkers gehanteerd. 
Tabel 6.2 Uitgangspunten voor de berekening van de kostprijs voor verwerking van één ton varkensdrijfmest (scenario's A1, A2 en B) of één ton digestaat na co-vergisting. Kosten en baten van vergisting zijn niet meegenomen. ${ }^{1}$

\begin{tabular}{|c|c|c|c|c|}
\hline \multirow[b]{2}{*}{ Parameter } & \multirow[b]{2}{*}{ Eenheid } & \multicolumn{2}{|c|}{ Scenario's voor varkensdrijfmest } & \multirow{2}{*}{$\begin{array}{l}\text { Digestaat na co- } \\
\text { vergisting } \\
\text { Scenario C } \\
\text { Decanter centrifuge, } \\
\text { microfiltratie en } \\
\text { omgekeerde osmose }\end{array}$} \\
\hline & & $\begin{array}{l}\text { Scenario A1 en A2 } \\
\text { Scheiding in dik/dun }\end{array}$ & $\begin{array}{l}\text { Scenario B } \\
\text { Zeefbandpers, DAF en } \\
\text { omgekeerde osmose }\end{array}$ & \\
\hline Vergisting & & Nee & Nee & $\mathrm{Ja}$ \\
\hline \multicolumn{5}{|c|}{ Eindproducten per ingaande ton mest } \\
\hline Dikke fractie & (kg/ton) & 200 & 200 & 135 \\
\hline NK-concentraat & (kg/ton) & - & 300 & 285 \\
\hline Dunne fractie & (kg/ton) & 800 & - & - \\
\hline MF-concentraat ${ }^{1}$ & (kg/ton) & - & - & 300 \\
\hline Loosbaar water & (kg/ton) & - & 500 & 180 \\
\hline Afbraak vergister & ( $\mathrm{kg} /$ ton) & & & 100 \\
\hline \multicolumn{5}{|l|}{ Chemieverbruik $^{2}$} \\
\hline Polymeer (poeder) & (kg/ton) & 0,50 & 0,50 & 0,25 \\
\hline Zwavelzuur, 98\% & (kg/ton) & - & 4,0 & 2,3 \\
\hline IJzersulfaat, $40 \%$ & (kg/ton) & - & 3,7 & - \\
\hline Magnesiumchloride, $32 \%$ & (kg/ton) & - & - & 1,8 \\
\hline \multicolumn{5}{|l|}{ Energieverbruik } \\
\hline $\begin{array}{l}\text { Gas/restwarmte t.b.v. } \\
\text { hygiënisatie }\end{array}$ & (MJ/ton) & 100 (aardgas) & 100 (aardgas) & 100 (uit restwarmte) \\
\hline Elektriciteit & (kWh/ton) & 9 & 18 & 24 \\
\hline \multicolumn{5}{|c|}{1 Concentraat van de microfiltratie met laag fosfaatgehalte; afzet onder de gebruiksnorm dierlijke mest in de akkerbouw in Nederland. } \\
\hline \multicolumn{5}{|c|}{$\begin{array}{l}\text { Chemie- en energieverbruik voor de verwerking van mest of digestaat. Chemieverbruik voor de vergister en biogasreiniging is niet beschouwd. } \\
\text { Gehanteerde dichtheden: } 98 \% \text { zwavelzuur } 1,84 \mathrm{~kg} / \mathrm{l} ; 40 \% \mathrm{Fe}_{3}\left(\mathrm{SO}_{4}\right)_{2} 1,54 \mathrm{~kg} / \mathrm{l} ; 32 \% \mathrm{MgCl}_{2} 1,31 \mathrm{~kg} / \mathrm{l} \text {. }\end{array}$} \\
\hline
\end{tabular}

\subsubsection{Vergisting}

Bij scenario $C$ wordt de kostprijs berekend voor de verwerking van digestaat. In dit rapport is op basis van de beschikbare gegevens de kostprijs per ton digestaat vastgesteld. Het uitsplitsen van de kostprijs voor de digestaatverwerking in kosten voor de mest en kosten voor de co-producten is zeer complex. Dit komt door de verwikkeling van de businesscase van digestaatverwerking met de businesscase van de vergistingsinstallatie. Immers, de biogasproductie is hoofdzakelijk toe te schrijven aan de co-producten (voor GZV komt circa $77 \%$ van de biogas uit co-producten en $23 \%$ uit mest, inclusief ongeboren mest) waardoor tevens het aandeel droge stof in het digestaat toeneemt. Dat vertaalt zich in hogere kosten door grotere volumes af te voeren dikke fractie en MF-concentraat ten opzichte van een situatie waarin ruwe drijfmest of mono-vergiste mest verwerkt zou worden. Daar staan echter inkomsten vanuit biogasproductie en beschikbaarheid van restwarmte tegenover. De dierlijke mest draagt beperkt bij aan de inkomsten van de biogasinstallatie. Gollenbeek et al. (2021) hanteren een voordeel van 2 euro per ton mest bij monovergisting als inkomsten uit biogas na aftrek van kosten voor vergisting. Echter, op basis van geluiden uit de praktijk wordt dit reeds als te positief beoordeeld.

Bij co-vergistingsinstallaties dient de mest ter verdunning van vaste co-producten, met andere woorden, zonder bijmenging van mest zou er water bijgemengd moeten worden en zou tevens een digestaatverwerking nodig zijn om water af te scheiden voor hergebruik. Een voordeel van vergisting is dat het volume mest met grofweg $10 \%$ afneemt door omzetting van organische stof naar biogas. Dit rapport presenteert de kostprijs van de verwerking en afzet van één ton digestaat ( $8 \%$ droge stof) uit een co-vergistingsinstallatie, waarbij is aangenomen dat de restwarmte gratis ter beschikking wordt gesteld aan de digestaatverwerking. 


\subsubsection{Kostprijzen energie en chemie}

Kostprijzen voor het verbruik elektriciteit en aardgas zijn opgenomen in Tabel 6.3. Voor elektriciteit is gerekend met $€ 0,07$ per kWh (gemiddeld prijsniveau 2020 grootverbruikers, CBS statline). Voor hygiënisatie van de dikke fractie is gerekend met het gemiddelde aardgastarief in 2020 (CBS statline) à $€ 0,011$ per MJ, m.u.v. scenario $C$, waarin restwarmte van de WKK beschikbaar is en waarvoor geen kosten zijn gerekend. De opwekking en levering van energie aan het net door vergisting waren geen onderdeel van de kostprijsberekening (zie toelichting paragraaf 6.2.3).

Voor de chemie zijn kostprijzen opgevraagd bij leveranciers (Tabel 7.2) waarbij de kostprijs behoorlijk verschilt voor levering in bulk versus levering in IBC. Voor zwavelzuur is uitgegaan van levering in bulk, wat betekent dat de verwerker een zuur-bestendigde opslagtank van minimaal $10 \mathrm{~m}^{3}$ ter beschikking moet hebben. Voor ijzersulfaat en magnesiumchloride is uitgegaan van levering in IBC en voor polymeer voor levering in zakken in lijn met de praktijksituatie. De kostprijs voor het verbruik van polymeer, zwavelzuur, ijzersulfaat en magnesiumchloride kan nauwkeurig worden vastgesteld. Aanvullend wordt er voor membraanfiltratie (MF en RO) gebruikgemaakt van o.a. antischuimmiddelen, antiscalants en reinigingsmiddelen en voor de regeneratie van ionenwisselaars zuren en basen. Als indicatie voor alle additionele chemische producten ten behoeve van membraanfiltratie en ionenwisselaars is aanvullend een kostenpost van $€ 0,75$ per ton mest opgenomen in scenario $B$ en $C$.

Tabel 6.3 Gehanteerde tarieven voor energie- en chemieverbruik voor verwerking van varkensdrijfmest.

\begin{tabular}{|c|c|c|c|}
\hline Parameter & Eenheid & Kostprijs & Toelichting \\
\hline Elektriciteit & $€ / k W h$ & $€ 0,07$ & CBS statline, prijsniveau 2020 voor grootverbruikers. ${ }^{1}$ \\
\hline Aardgas & $€ / M]$ & $€ 0,011$ & CBS statline, prijsniveau 2020 voor grootverbruikers. ${ }^{1}$ \\
\hline Restwarmte & $€ / M J$ & $€ 0,011$ & $\begin{array}{l}\text { De verwerker 'koopt' de restwarmte van de vergistingsinstallatie. } \\
\text { Restwarmte vertegenwoordigt een economische waarde, omdat de } \\
\text { verwerker een hogere opbrengst per } \mathrm{m}^{3} \text { biogas kan genereren door } \\
\text { afzet als biogas of groengas t.o.v. omzetting tot elektriciteit en } \\
\text { warmte. }\end{array}$ \\
\hline Zwavelzuur, 98\% & $€ / \mathrm{kg}$ & $€ 0,15$ & Bij levering in bulk en opslag in tank \\
\hline Polymeer (poeder) & $€ / \mathrm{kg}$ & $€ 4,00$ & Bij levering in zak \\
\hline IJzersulfaat, $40 \%$ & $€ / \mathrm{kg}$ & $€ 0,25$ & Bij levering in IBC \\
\hline Magnesiumchloride, $32 \%$ & $€ / \mathrm{kg}$ & $€ 0,15$ & Bij levering in IBC \\
\hline Kosten overige chemie & $€ /$ ton mest & $€ 0,75$ & $\begin{array}{l}\text { Schatting kosten per ton ingaande mest of digestaat voor o.a. } \\
\text { reinigingsmiddelen, antischuimmiddelen, regeneratiemiddelen en } \\
\text { antiscalants. }\end{array}$ \\
\hline
\end{tabular}

\subsubsection{Afzetkosten eindproducten}

Tabel 6.4 toont de gemiddelde afzetkosten voor de eindproducten. Dit betreft de kosten die de verwerker maakt voor afzet van de mestproducten en is opgebouwd uit kosten voor:

- Opslag van de eindproducten buiten het groeiseizoen

- Bemonstering en chemische analyse

- De 'verkoop' aan de afnemer (positief/negatief)

- Transport van verwerker naar afnemer

Er zijn verschillen in afzetkosten voor gelijkwaardige eindproducten tussen de deelnemende verwerkers, o.a. veroorzaakt door verschillen in ligging van de verwerkingslocatie. Er is gerekend met gemiddelde afzetkosten. Daarnaast is sprake van fluctuaties in afzetkosten. De hier getoonde kosten gelden voor het winterseizoen 2020/2021 (peildatum februari 2021) en zijn laag ten opzichte van voorgaande jaren.

Voor de afzet van gehygiëniseerde dikke fractie naar Noord-Frankrijk of Duitsland is gerekend met een netto kostprijs van $€ 18$ per ton afgezette dikke fractie. De ontvangende agrariër betaalt circa $€ 7$ per 
ton dikke fractie. De afzetkosten voor de verwerker bestaan hoofdzakelijk uit transportkosten, wat circa $€ 25$ per ton is. Er zijn aanzienlijke verschillen in de afzetkosten voor dikke fractie tussen de deelnemende verwerkers. Zo levert afzet onder het Fertigarant kwaliteitssysteem $€ 2$ per ton voordeel op door het vervallen van de verplichte monstername per afgevoerde vracht. De afzetkosten voor dikke fractie zijn de laatste jaren fors gedaald. Enkele jaren geleden werden nog afzetkosten van $€ 22$ tot $€ 25$ per ton dikke fractie genoemd.

In scenario B wordt NK-concentraat benut als kunstmestvervanger boven op de gebruiksnorm dierlijke mest. De verwerker betaalt kosten voor opslag buiten het bemestingsseizoen, transport naar de afnemer en bemonstering. Er is gerekend met een kostenpost van $€ 8$ per ton afgezet NK-concentraat voor de verwerker, uitgaande van afzet binnen een straal van $25 \mathrm{~km}$. De afnemer krijgt het NKconcentraat gratis geleverd en draagt zelf de kosten voor de aanwending.

In scenario $\mathrm{C}$ wordt het NK-concentraat geblend met de stikstofmeststoffen ammoniumnitraat en ureum en/of ammoniumsulfaat tot een product dat verkocht wordt onder de merknaam 'Groene Weide Meststof' (GWM) met een gemiddelde samenstelling van $14,8 \mathrm{~g} \mathrm{~N} / \mathrm{kg}, 9,4 \mathrm{~g} \mathrm{~K}_{2} \mathrm{O} / \mathrm{kg}$ en $12,2 \mathrm{~g} \mathrm{SO}_{3} / \mathrm{kg}$. De stikstof in de GWM is voor circa $50 \%$ afkomstig uit NK-concentraat, voor $25 \%$ uit herwonnen stikstof (o.a. ammoniumsulfaat) en voor $25 \%$ uit synthetische stikstofmeststoffen. Door het bijmengen van stikstof uit andere bronnen past de verhouding tussen stikstof, kalium en zwavel beter bij de gewasbehoefte. De verwerker maakt kosten voor de aankoop en blending van de toegevoegde stikstofmeststof ( $€ 9$ per ton NK-concentraat). De ontvangende agrariër betaalt circa $€ 1,15$ per $\mathrm{kg} \mathrm{N}$ in de GWM en in deze prijs is aanwending via mestinjectie inbegrepen. Uitgangspunt is dat de kosten voor de afnemer gelijk zijn aan het gebruik van reguliere kunstmest. De inkomsten uit de verkoop van de GWM zijn ongeveer gelijk aan de som van inkoopkosten van de toegevoegde stikstofmeststoffen en de aanwendingskosten. GZV schat dat de totale door GZV gemaakte afzetkosten voor het NKconcentraat, inclusief de kosten voor de opslag ervan buiten het bemestingsseizoen, circa $€ 8$ per ton NK-concentraat zijn. Afzet van de 'GWM' is op dit moment dus een kostenpost voor GZV.

De afzetkosten voor dunne fractie van mest hangen af van de transportafstand tot akkerbouwgebied. $\mathrm{Er}$ is gerekend met een afzetprijs van $€ 16$ per ton bij een transportafstand van $100-150 \mathrm{~km}$. Dit is opgebouwd uit kosten voor bemonstering ( $€$ 2/ton), vergoeding afnemer ( $€$ 5/ton) en transport ( $€$ 9/ton). Bij een transportafstand van $50 \mathrm{~km}$ is gerekend met een afzetprijs van $€ 11$ per ton dunne fractie vanwege de lagere transportkosten. Het MF-concentraat in scenario $C$ wordt als stikstofrijke mest afgezet naar de akkerbouw tegen $€ 18$ per ton (hogere kosten t.o.v. dunne fractie door hogere gehalten stikstof waardoor de afnemer minder ton mest per hectare kan aannemen). 
Tabel 6.4 Gehanteerde kostprijzen voor de aanvoer van varkensdrijfmest en de afzet van eindproducten van mestverwerking. Aanvoer- en afzetkosten zijn inclusief transportkosten, opslagkosten en bemonsteringskosten (peildatum februari 2021).

\begin{tabular}{|c|c|c|c|}
\hline Omschrijving & Eenheid & Kostprijs & Toelichting \\
\hline Aanvoer mest naar mestverwerker & $€ /$ ton & $€ 3,50$ & $\begin{array}{l}\text { Kostprijs transport mest van boer naar mestverwerker, } \\
\text { inclusief bemonstering. }\end{array}$ \\
\hline MF-concentraat & $€ /$ ton & $€ 17,00$ & $\begin{array}{l}\text { Bij afzet naar akkerbouw binnen Nederland gelijk aan } \\
\text { mestprijs. Bevat circa } 8 \mathrm{~g} \mathrm{~N} / \mathrm{kg} \text {. }\end{array}$ \\
\hline $\begin{array}{l}\text { Dunne fractie: } 100-150 \mathrm{~km} \text { afstand tot } \\
\text { akkerbouw }\end{array}$ & $€ /$ ton & $€ 16,00$ & $\begin{array}{l}\text { Kostprijs voor een verwerker op } 100-150 \mathrm{~km} \text { afstand } \\
\text { van akkerbouwgebied (scenario A1). Bevat circa } 4 \mathrm{~g} \\
\mathrm{~N} / \mathrm{kg} \text {. }\end{array}$ \\
\hline NK-concentraat als kunstmestvervanger & $€ /$ ton & $€ 9,50$ & $\begin{array}{l}\text { Gemiddelde kostprijs inclusief opslag bij de verwerker of } \\
\text { bij de afnemer. De verwerker draagt de transportkosten. } \\
\text { De afnemer betaalt niet voor afname van het product, } \\
\text { maar draagt wel de kosten voor de aanwenden. }\end{array}$ \\
\hline $\begin{array}{l}\text { NK-concentraat als kunstmestvervanger } \\
\text { via blending tot 'Groene Weide Meststof' }\end{array}$ & $€ /$ ton & $€ 8,00$ & $\begin{array}{l}\text { Gemiddelde kostprijs waarbij NK-concentraat wordt } \\
\text { geblend met andere stikstofmeststoffen tot een meststof } \\
\text { met } 14 \mathrm{~g} \mathrm{~N} / \mathrm{kg} \text { waarvan minimaal } 50 \% \text { afkomstig is uit } \\
\text { NK-concentraat. De verwerker verzorgt de emissiearme } \\
\text { aanwending via injectie. De afnemer betaalt circa } € 1,15 \\
\text { per kg N inclusief aanwending. } \\
\text { Kostprijzen per ton NK-concentraat: } \\
\text { - opslag, transport, bemonstering }(€ 7) \\
\text { - aankoop en blending N-meststoffen }(€ 9) \\
\text { - aanwending via injectie ( } € 8) \\
\text { - verkoop ( } € \text {-16) } \\
\text { - netto kostprijs voor verwerker: } € 8\end{array}$ \\
\hline
\end{tabular}

\subsubsection{Afschrijving, onderhoud en bedrijfsvoering van mestverwerkingsinstallaties}

Tabel 6.5 toont de geschatte eenmalige investeringskosten en jaarlijks terugkerende kosten voor een mestverwerkingsinstallatie met een capaciteit van 100.000 ton per jaar (het betreft een indicatie). De investeringskosten voor de installatie zijn geschat, waarna de kosten voor afschrijving (10\% per jaar) en rente over de lening ( $3 \%$ per jaar) zijn berekend. Er is gerekend met een afschrijvingstermijn van tien jaar. In de praktijk blijkt dat verwerkers zelf rekenen met afschrijving over vijf jaar vanwege de snelle slijtage van apparatuur bij verwerking van mest en de onzekerheid of de investering over tien jaar nog aansluit bij de dan geldende marktvraag en regelgeving.

Kosten voor de aankoop van grond en de bouw van bedrijfshallen zijn niet inbegrepen. Onderhoudsen verzekeringskosten zijn meegenomen. Kosten voor personeel zijn bepaald op basis van door de verwerkers verstrekte gegevens. Mestverwerkers met een RO-installatie hebben gemiddeld één fte aan personeel in dienst als procesoperator. Daarnaast is er personeel in dienst voor het inplannen van mesttransporten, administratieve en financiële taken en management. 
Tabel 6.5 Geschatte eenmalige investeringskosten en jaarlijks terugkerende kosten voor een mestverwerkingsinstallatie met een capaciteit van 100.000 ton per jaar, exclusief kosten voor aankoop grond en gebouwen en exclusief vergistingsinstallatie. Omschrijving scenario's: zie tekst.

\begin{tabular}{|c|c|c|c|}
\hline & $\begin{array}{l}\text { Scenario A } \\
\text { (mest) }\end{array}$ & $\begin{array}{l}\text { Scenario B } \\
\text { (mest) }\end{array}$ & $\begin{array}{l}\text { Scenario C } \\
\text { (digestaat) }\end{array}$ \\
\hline \multicolumn{4}{|l|}{ Investeringskosten (eenmalig) } \\
\hline DAF-installatie & - & $€ 100.000$ & - \\
\hline Twee decanter centrifuges & - & - & $€ 400.000$ \\
\hline $\begin{array}{l}\text { Omgekeerde osmose-installatie en } \\
\text { Ionenwisselaar }\end{array}$ & - & $€ 700.000$ & $€ 700.000$ \\
\hline Hygiënisatie-unit & $€ 100.000$ & $€ 100.000$ & $€ 100.000$ \\
\hline Luchtwassers en overige & $€ 300.000$ & $€ 500.000$ & $€ 500.000$ \\
\hline Onderhoudskosten & $€ 50.000$ & $€ 250.000$ & $€ 250.000$ \\
\hline Loonkosten & $€ 100.000$ & $€ 150.000$ & $€ 150.000$ \\
\hline Verzekeringen & $€ 20.000$ & $€ 20.000$ & $€ 20.000$ \\
\hline Totaal per ton mest of digestaat & $€ 2,74$ & $€ 6,54$ & $€ 6,80$ \\
\hline
\end{tabular}

\subsubsection{Inkomsten uit vervangende verwerkingsovereenkomsten}

Indien een veehouder meer fosfaat uit zijn geproduceerde mest laat verwerken dan op basis van de mestverwerkingsplicht noodzakelijk is, kan het extra verwerkte fosfaat inkomsten geven door verkoop van de daarmee verkregen VVO's aan andere veehouders. De koper van de VVO's koopt daarmee zijn mestverwerkingsplicht af en mag zijn mest binnen Nederland afzetten. De kopende veehouder moet nog wel aan de mestboekhouding voldoen en het bedrijfsoverschot aan mest in termen van fosfaat afvoeren. De waarde ${ }^{18}$ van de VVO's is sinds de introductie in 2014 sterk gedaald en schommelde in 2020 rond de $€ 0,50$ per $\mathrm{kg} \mathrm{P}_{2} \mathrm{O}_{5}$. Voor varkensdrijfmest met een gemiddeld fosfaatgehalte van $3,7 \mathrm{~g} / \mathrm{kg}$ komt dit overeen met een waarde van $€ 1,85$ per ton mest.

\subsection{Resultaten}

\subsubsection{Kostprijzen mestverwerking (scenario's A en B)}

Figuur 6.1 geeft de opbouw van de kostprijs voor verwerking van varkensdrijfmest voor drie scenario's.

Bij scheiding van drijfmest in een dikke en dunne fractie is het minimale poorttarief, i.e. zonder winstmarge, circa $€ 19$ per ton mest bij afzet van de dunne fractie binnen $50 \mathrm{~km}$ afstand van de verwerker (scenario A1). Dit minimale poorttarief is circa $€ 23$ per ton indien de verwerker de dunne fractie over $150 \mathrm{~km}$ afstand moet transporteren (scenario A2). Bij opwerking van de dunne fractie tot NK-concentraat is er een verschuiving van afzetkosten naar operationele kosten en afschrijving. Een poorttarief van circa $€ 20$ voor scenario B is hierbij kostendekkend. Opwerking tot NK-concentraat geeft een klein voordeel ten opzichte van scheiding in een dikke en dunne fractie indien de verwerker de dunne fractie over lange afstand $(>150 \mathrm{~km}$ ) zou moeten afzetten. Indien de verwerker de dunne fractie op korte afstand kan afzetten $(<50 \mathrm{~km})$, geeft de berekening geen kostenvoordeel voor opwerking van dunne fractie tot NK-concentraat. De verschillen in de kostprijzen tussen de scenario's zijn echter klein t.o.v. de onzekerheden in de grootte van de kostenposten.

\footnotetext{
${ }^{18}$ https://www.fosfaat.nu/\#
} 
De veehouder betaalt naast het poorttarief ook de aanvoer van de mest naar de verwerker (circa $€ 3,50$ per ton mest). Daardoor variëren de minimale afzetkosten voor de veehouder van $€ 22,40$ tot $€ 26,40$ per ton drijfmest inclusief fosfaatverwerking volgens de wettelijke definitie (Figuur 6.2).

Het poorttarief voor de inname van mest is afhankelijk van vraag en aanbod op de markt en moet minimaal gelijk zijn aan de kostprijs om kostenneutraal te draaien. De veehouder betaalt daarnaast kosten voor de aanvoer van mest naar de verwerker (circa $€ 3,50$ per ton mest), waardoor de minimale afvoerkosten $€ 22$ tot $€ 26$ bedragen voor de drie scenario's. Indien de veehouder meer mest verwerkt dan op basis van het bedrijfsoverschot verplicht is, kan de veehouder de VVO's verhandelen. Bij een gemiddeld fosfaatgehalte in varkensdrijfmest van $3.7 \mathrm{~g} / \mathrm{kg}$ en een VVO-waarde van $€ 0,50$ per $\mathrm{kg} \mathrm{P}_{2} \mathrm{O}_{5}$, leveren de VVO's $€ 1,85$ per ton mest op. Bij de lage waarde van de VVO's zoals in 2020 dragen de VVO's dus nauwelijks bij in de kosten voor verwerking van mest.

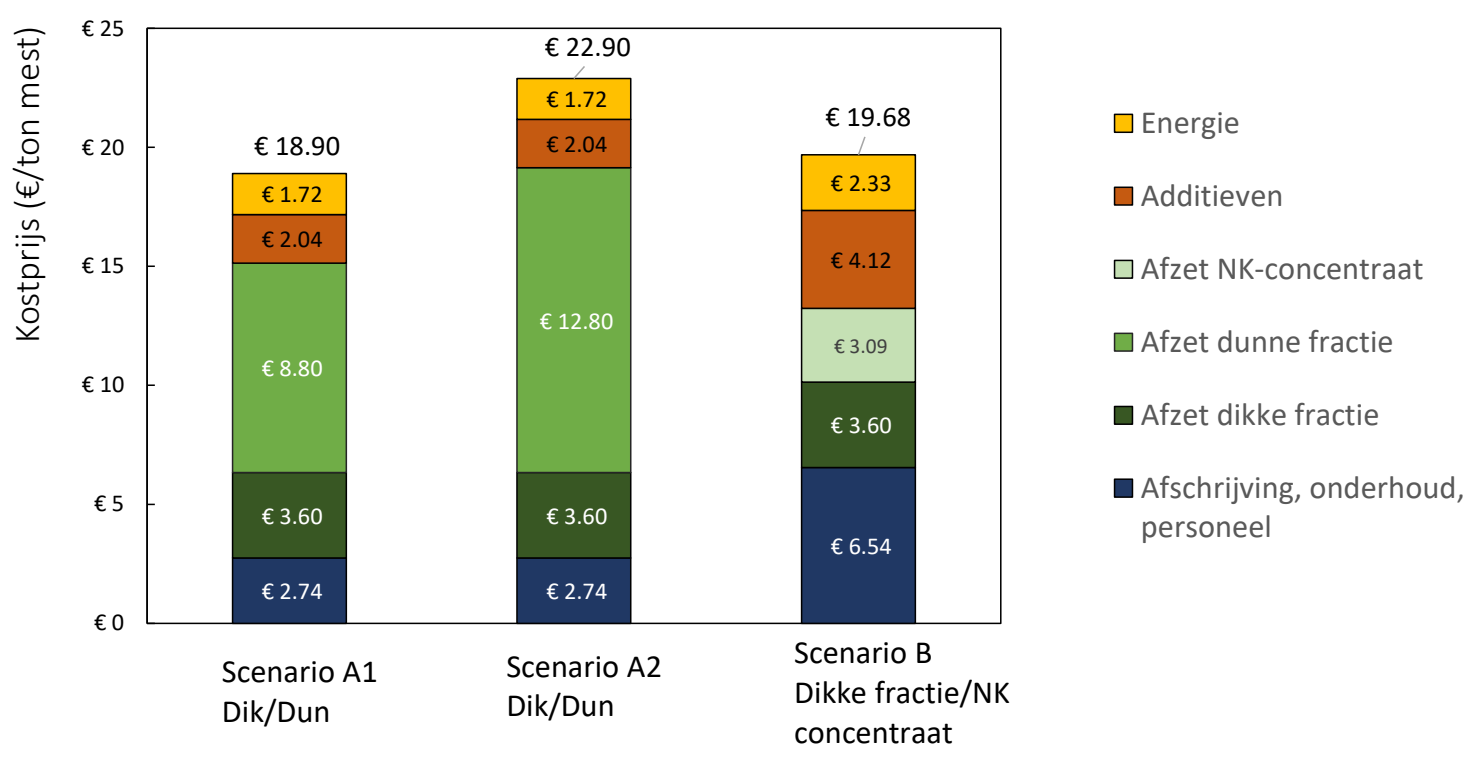

Figuur 6.1 Berekende poorttarieven voor mestscheiding in dik/dun waarbij de dunne fractie wordt afgezet op $50 \mathrm{~km}$ afstand (Scenario A1) of op $150 \mathrm{~km}$ afstand (Scenario A2), mestscheiding in dik/NKconcentraat (Scenario B) en scheiding van co-vergiste mest in dik/NK-concentraat en een reststroom (Scenario C). Voor volledige omschrijving: scenario's zie tekst.

\subsubsection{Kostprijs digestaatverwerking (scenario C)}

Figuur 6.2 toont de opbouw van de kostprijs voor verwerking van co-vergiste mest volgens scenario $\mathrm{C}$. De kostprijs is berekend op $€ 21$ euro/ton digestaat en bestaat voor circa $50 \%$ uit kosten voor de afvoer van de eindproducten en voor circa $30 \%$ uit kosten voor afschrijving, onderhoud en personeel. Energiekosten zijn relatief laag, mede door kosteloos gebruik van restwarmte vanuit de biogasmotor. Kosten voor chemieverbruik zijn relatief laag door de keuze om digestaat te scheiden met decanter centrifuges en MF waardoor minder polymeer wordt verbruikt ten opzichte van scheiding met een zeefbandpers en DAF. Een aandachtspunt is de hoge kostenpost voor de afvoer van het MFconcentraat, dat onder de gebruiksnorm dierlijke mest wordt afgezet binnen de Nederlandse landbouw. De MF scheidt fijne deeltjes af die de decanter centrifuges passeren en de MF dient om een schone, deeltjesvrije stroom te creëren als voeding voor de RO-installaties. Het MF-concentraat kent een laag drogestofgehalte en groot volume per ton ingaand digestaat. Door het volume MFconcentraat te verlagen, wat tevens zal leiden tot een hogere waterproductie, kan de kostprijs voor digestaatverwerking verbeterd worden. Dit is reeds lange tijd een aandachtspunt bij GZV, maar terugdringen van het volume aan MF-concentraat blijkt in de praktijk een lastige opgave. In hoeverre de omvang van en/of het type co-producten hierbij een rol spelen, is niet vast te stellen binnen dit project. 
De kostprijs voor verwerking van digestaat uit een co-vergistingsinstallatie kan niet vergeleken worden met de kostprijs voor verwerking van ruwe mest, omdat de businesscase van de digestaatverwerking is verweven met de businesscase van de vergistingsinstallatie. Het bijmengen van co-producten leidt immers tot een hoger drogestofgehalte in het digestaat, waardoor het volume af te voeren eindproducten toeneemt. Hygiënisatie met restwarmte (kosteloos) geeft een voordeel van circa $€ 1$ per ton digestaat t.o.v. het gebruik van aardgas en dit voordeel is daarmee bij de huidige energieprijzen beperkt. Het uitsplitsen van de kosten voor de digestaatverwerking naar de mestverwerkingstak en de biogasproductietak was geen onderdeel van deze studie. Echter, op basis van bovenstaande redenatie mag wel verwacht worden dat de kostprijs voor verwerking van één ton mest significant lager is dan de kostprijs voor de verwerking van één ton digestaat uit de co-vergister.

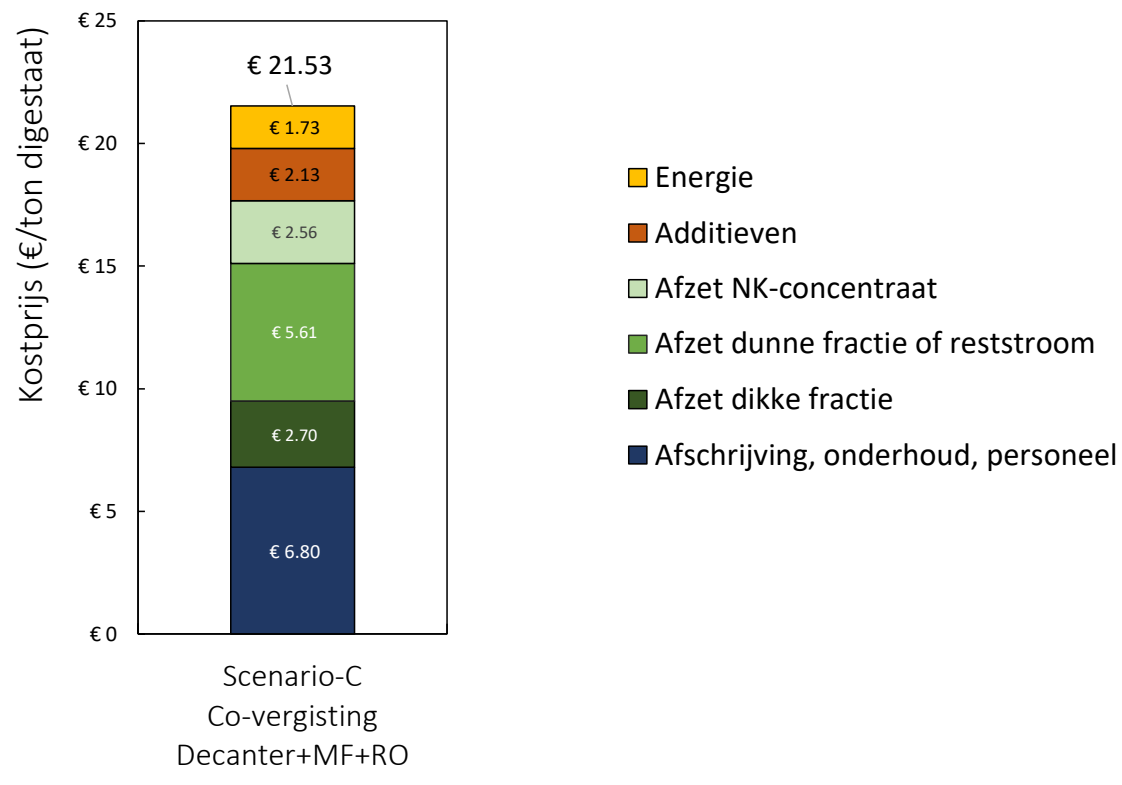

Figuur 6.2 Opbouw kostprijs voor de verwerking van één ton digestaat uit een covergistingsinstallatie. De kostprijs van digestaatverwerking is verweven met de businesscase van de vergistingsinstallatie en kan zodoende niet vergeleken worden met de kostprijs voor verwerking van ruwe mest. Door co-vergisting kent digestaat een hoger drogestofgehalte ten opzichte van ruwe mest en dit leidt tot hogere kosten voor de afvoer van droge stof (via de dikke fractie en het microfiltratieconcentraat).

\subsubsection{Discussie}

Mogelijkheden om het poorttarief voor hoogwaardige mestverwerking te verlagen, zijn beperkt. Een mogelijkheid tot optimalisatie is het verlagen van de chemiekosten, al zal het poorttarief er maar beperkt door dalen. Ook geven de verwerkers aan dat ze de chemiedosering al zo efficiënt mogelijk inzetten. Een andere mogelijkheid is het verhogen van de marktwaarde van de eindproducten. De marktpositie van bewerkte mest is de laatste jaren verbeterd en verwerkers geven aan dat er voldoende vraag is naar zowel NK-concentraat als dikke fractie. Afzetkosten voor dikke fracties zijn de laatste jaren sterk gedaald. Dikke fracties worden afgezet naar Noord-Frankrijk of Duitsland waar de afnemer naar schatting $€ 8$ per ton betaalt. De prijs wordt bepaald door het stikstof- en fosfaatgehalte; productie van een dikke fractie zonder toevoeging van polymeer en/of ijzerzouten resulteert niet in een hogere marktwaarde. Een financieel motief om dergelijke chemie niet te gebruiken, ontbreekt daardoor. Het drogen en korrelen van dikke fractie verhoogt de marktwaarde aanzienlijk, echter het behaalde financiële voordeel hangt af van de beschikbaarheid van een goedkope warmtebron of restwarmte.

In de regel betaalt de afnemer niet voor ontvangst van NK-concentraat. Op basis van het stikstofgehalte $(8 \mathrm{~g} \mathrm{~N} / \mathrm{kg}$ ) en de gemiddelde kunstmestprijs bedraagt de waarde van een ton NKconcentraat circa $€ 8,80$ per ton. De waarde van kalium en zwavel zijn hierin niet meegerekend, 
omdat dit in NK-concentraten vaak in overmaat aanwezig is ten opzichte van de gewasbehoefte. Een afnemer zal deze nutriënten daarom niet, of niet volledig, waarderen. Een deel van de waarde van NKconcentraat gaat echter teniet door de hogere aanwendingskosten voor injectie ten opzichte van het goedkopere uitstrooien van kunstmestkorrels. Stel dat de verwerker na aftrek van de aanwendingskosten $€ 5$ euro per ton NK-concentraat verdient, dan levert dit een voordeel op van circa $€ 1,50$ per ton ingaande mest. Het effect op het poorttarief is daarmee beperkt. Dit blijkt ook uit de businesscase van GZV voor blending van NK-concentraat met andere stikstofmeststoffen tot een meststof met circa $15 \mathrm{~g} \mathrm{~N} / \mathrm{kg}$ en een N:K:S-ratio afgestemd op de gewasbehoefte. De door de afnemer betaalde prijs voor de blend is o.b.v. de kunstmestprijs en GZV draagt de kosten voor injectie van de meststof. Het economisch voordeel van deze werkwijze ten opzichte van andere verwerkers is beperkt. Het is haalbaar om de afnemer te laten betalen voor NK-concentraat. Echter, de afzet ervan blijft een kostenpost voor de verwerker, omdat de opbrengst niet opweegt tegen de kosten voor bemonstering, transport, aanwending en opslag buiten het seizoen.

Een veehouder is verplicht een deel van het bedrijfsoverschot aan mest te laten verwerken, waarbij het fosfaat buiten de Nederlandse landbouw dient afgezet te worden. Indien de veehouder meer mest laat verwerken dan op basis van zijn eigen overschot verplicht is, kan dit inkomsten geven door verkoop van VVO's. Anderzijds kan de veehouder mest afzetten op de binnenlandse markt en de mestverwerkingsplicht afkopen door aankoop van VVO's. De waarde van de VVO's is sinds de invoering fors gedaald. In 2020 daalde de waarde van de VVO's tot circa $€ 0,50$ per $\mathrm{kg}_{2} \mathrm{O}_{5}$, wat overeenkomt met $€ 1,85$ per ton varkensdrijfmest bij een fosfaatgehalte van $3,7 \mathrm{~g} \mathrm{P}_{2} \mathrm{O}_{5} / \mathrm{kg}$. De lage prijs van de VVO's is mede het gevolg van 'de productie' van VVO's door verwerking van kippenmest, waardoor het aanbod aan VVO's hoog is t.o.v. de hoeveelheid verplicht te verwerken fosfaat (NCM, 2020). Daarnaast speelt ook de daling in de totale fosfaatuitscheiding in Nederland een rol, waardoor minder fosfaat verwerkt hoeft te worden (hoofdstuk 8). Dit vertaalt zich ook in een daling van de gemiddelde afzetprijzen voor varkensdrijfmest ten opzichte van de piek in 2018. In 2019 bedroeg het gemiddelde afzettarief $€ 19,90$ per ton varkensmest. ${ }^{19}$ Een gemiddelde afzetprijs voor 2020 is nog niet gepubliceerd op agrimatie. $\mathrm{nl}$, maar bekend is dat sprake is van een dalende trend. Bij deze prijzen voor mestafzet i.c.m. een lage prijs van de VVO's, is het voor een veehouder gunstiger om de mest op de binnenlandse markt af te zetten in plaats van af te voeren naar een verwerker.

In de praktijk blijkt dat verwerkers in 2020 minder mest ontvingen dan voorheen, wat door onderbenutting van de verwerkingscapaciteit tot een kostprijsverhoging leidt. Tegelijkertijd dalen de afzetprijzen voor distributie van varkensdrijfmest op de binnenlandse markt, waardoor ook poorttarieven mee moeten dalen. Een verwerker met een lowtech-verwerking, zoals scheiding in $\mathrm{dik} /$ dun, zal het poorttarief deels kunnen laten meebewegen, omdat de afzetprijs voor dunne fractie mest eveneens daalt bij een lager aanbod aan mest op de markt. Voor meer hoogwaardige verwerking, waaronder scheiding tot NK-concentraat, is deze mogelijkheid beperkter, omdat het poorttarief voor grofweg $50 \%$ bestaat uit operationele kosten (energie, chemie en personeel) en onderhouds- en afschrijvingskosten en omdat de marktwaarde voor NK-concentraat bij gebruik als kunstmestvervanger niet per se toeneemt bij een lager aanbod aan mest op de markt.

Recent zijn in het kader van het TKI PPS-project NL Next Level Mestverwaarding poorttarieven berekend voor hoogwaardige verwerking van mest tot mestkorrels en ammoniumsulfaat of ammoniumnitraat (Gollenbeek et al., 2020). Poorttarieven hiervoor zijn vastgesteld op $€ 25$ tot $€ 30$ per ton (exclusief aanvoer van de mest) bij een verwerkingscapaciteit van 250 kton mest per jaar zonder vergisting. Deze hoogwaardige manieren van mestverwerking - waarbij geconcentreerde minerale stikstofmeststoffen worden geproduceerd - leiden dus niet tot een lagere kostprijs voor mestverwerking vergeleken met de huidige gangbare mestverwerkingstechnieken. De hogere marktwaarde van de eindproducten weegt niet op tegen de meerkosten voor de verwerking. Door monovergisting kan volgens Gollenbeek et al. (2020) het poorttarief met $€ 2$ tot 3 per ton dalen. Echter, de businesscase van mestvergisting kent ook een grote onzekerheid vanwege de afhankelijkheid van de hoogte van subsidies en tarieven voor energie- en groencertificaten.

\footnotetext{
${ }^{19}$ www.agrimatie.nl - Mestafzetkosten
} 
Bij het huidige systeem - waarin de verplichting tot mestverwerking is gebaseerd op het bedrijfsoverschot aan fosfaat - en de dalende trend in de totale fosfaatuitscheiding zal het mestaanbod bij verwerkers dalen. Bij een daling van het mest- en fosfaatoverschot kan mestverwerking op basis van kostprijs niet concurreren met afzet van onbewerkte mest op de binnenlandse markt. Het ministerie van LNV heeft in het kader van de Routekaart Toekomstig Mestbeleid voorgesteld om in te zetten op meer mestverwerking door overgang naar een tweesporenbeleid, waarbij de veehouder ofwel grondgebonden is qua mestproductie, ofwel alle mest naar een verwerker afzet. ${ }^{20}$ In de afgelopen vier jaar is de politieke aandacht voor mest verschoven van fosfaatverwerking naar het voorkomen van emissies van ammoniak (stikstofdepositie op kwetsbare natuur) en het behalen van klimaatdoelen (emissies van koolstofdioxide, lachgas en methaan). Mestverwerking wordt gezien als middel om aan deze doelen bij te dragen, maar dit levert vooralsnog geen financieel voordeel op voor de verwerker of de veehouder. De invulling van dit nieuwe beleid is nog onbekend, waarmee ook de toekomst voor mestverwerkers in termen van mestaanbod en manier van verwerken onzeker is. Bij een verdere uitwerking van plannen voor verplichte verwerking van alle niet-grondgebonden mest van veehouders (tweesporenbeleid) moet daarom ook aandacht zijn voor de financiële haalbaarheid.

\subsection{Kosten en baten fosfaatafscheiding met RePeat}

GZV verwerkt met het RePeat-systeem sinds 2020 een deel van de dikke fractie tot een fosfaatarme bodemverbeteraar en een fosfaatprecipitaat. Tabel 6.6 toont het berekende kostenoverzicht voor dit systeem. Ook toont het de businesscase voor drie scenario's voor de verwerking en afzet van de door het GENIAAL-systeem geproduceerde dikke fractie: reguliere afzet, productie van bodemverbeteraar via RePeat en productie van veenvervanger via RePeat.

Het RePeat-systeem is op dit moment op werkdagen circa 4 tot 8 uur per dag in bedrijf, terwijl het is ontworpen om 24 uur per dag te draaien en daarmee alle, door het GENIAAL-systeem, geproduceerde dikke fractie te verwerken. Voor het berekende kostenoverzicht is aangenomen dat de volledige verwerkingscapaciteit van de installatie wordt benut (14 kton dikke fractie/jaar en $80 \%$ van de tijd operationeel). Dit geldt specifiek ook voor de kosten voor energieverbruik en afschrijving. Grote kostenposten zijn het zwavelzuurverbruik ( $€$ 4,68 per ton ingaande dikke fractie) en kalkmelk $(€ 3,64$ per ton ingaande dikke fractie). Hierbij is uitgegaan van aanlevering in bulk, op locatie moet dus een opslagtank aanwezig zijn. Voor de opslag van $98 \%$ zwavelzuur gebruikt GZV de al aanwezige opslagtank van het GENIAAL-systeem. Bij levering van chemie in IBC's stijgen de kosten. De elektriciteitskosten zijn berekend op $€ 1,40$ per ton ingaande dikke fractie onder de aanname dat de installatie 24 uur per dag draait. Wanneer de installatie niet draait, wordt er - ter beheersing van emissies van waterstofsulfide - elektriciteit verbruikt door roerders, beluchters en afzuigers. Bij onderbenutting van de verwerkingscapaciteit stijgen daardoor de elektriciteitskosten per ton ingaande dikke fractie. De eenmalige investeringskosten voor de installatie zijn geraamd op $€ 400.000$ euro waarbij de installatie geplaatst wordt in een bestaande hal en de luchtafzuiging op een bestaande luchtwasser wordt aangesloten. De jaarlijkse onderhoudskosten zijn naar verwachting beperkt en geraamd op $5 \%$ van de investeringskosten. Er is gerekend met een afschrijvingstermijn van 7 jaar en leningsrente van $5 \%$. Verder is 0,5 fte aan personeel voor procesaansturing geraamd.

In het scenario voor verwerking van ingaande dikke fractie tot bodemverbeteraar wordt één ton dikke fractie omgezet in $700 \mathrm{~kg}$ bodemverbeteraar en $500 \mathrm{~kg}$ fosfaatprecipitaat (als slib). Als restproduct ontstaat nog $300 \mathrm{~kg}$ slib van de lamellenbezinker, dat gemengd met het MF-concentraat van het GENIAAL-systeem wordt afgezet. Hiervoor wordt 15 euro per ton slib van de lamellenbezinker gerekend. De totale massa van de uitgaande stromen is meer dan $100 \%$ van de massa ingaande dikke fractie door toevoeging van spoelwater (zie hoofdstuk 3). De ontwatering van het fosfaatprecipitaat gaat nog niet zoals beoogd. Uit eerdere pilotproeven bleek dat gebruik van magnesiumhydroxide, waarbij struviet wordt gevormd, een aanzienlijk hoger drogestofgehalte van het fosfaatprecipitaat oplevert in vergelijking met gebruik van kalkmelk. Vanwege de meerkosten van magnesiumhydroxide t.o.v. van kalkmelk wordt echter vooralsnog kalkmelk gedoseerd, wat resulteert

\footnotetext{
${ }^{20}$ Routekaart toekomstig mestbeleid, kamerbrief, 14 april 2021, DGA-PAV / 21066300
} 
in een fosfaatprecipitaat met een drogestofgehalte van circa $20 \%$. Dit fosfaatslib wordt op het moment binnen de Nederlandse landbouw afgezet naar akkerbouwers. In 2021 zal, in het kader van het opvolgende TKI-project BIOVALOR, een struvietreactor geplaatst worden om een droger fosfaatproduct te produceren dat geschikt is voor afzet naar de organische meststoffenindustrie. In Tabel 6.6 is uitgegaan van de afvoer van fosfaatprecipitaat als slib, waardoor de totale afzetkosten voor de eindproducten van het RePeat-systeem hoger uitvallen dan beoogd.

In het scenario voor reguliere afzet van de door het GENIAAL-systeem geproduceerde (gehygiëniseerde) dikke fractie zijn de afzetkosten voor export $€ 18$ per ton. De afzetkosten voor dikke fractie zijn de laatste jaren sterk gedaald. De in 2019 berekende businesscase ging nog uit van afzet voor $€ 25$ per ton dikke fractie. Tegelijkertijd zijn er ook ontwikkelingen geweest in de afzetmogelijkheden voor de bodemverbeteraar. Naast afzet als bodemverbeteraar, circa $€ 4$ per ton opbrengst, is dit vezelachtige product ook geschikt als veenvervanger in potgrond of in dekaarde voor champignonteelt (Sigurnjak et al., 2021). Bij afzet als veenvervanger naar deze markten heeft de bodemverbeteraar een waarde aan de poort van circa $€ 15$ per $\mathrm{m}^{3}$ product. Vanwege de lage bulkdichtheid $\left(330 \mathrm{~kg} / \mathrm{m}^{3}\right.$ ) van de bodemverbeteraar, komt dit overeen met circa $€ 45$ per ton product. Er is echter uitgegaan van een voorzichtige schatting van $€ 15$ per ton voor afzet als veenvervanger. In Tabel 6.6 is uitgegaan van een voorzichtige businesscase met inkomsten van $€ 4$ per ton voor afzet als bodemverbeteraar en $€ 15$ per ton voor afzet als veenvervanger.

Bij afzet als bodemverbeteraar naar de landbouw, waarbij de afnemer $€ 4$ per ton betaalt, zijn de totale kosten voor GZV hoger dan de kosten voor reguliere afzet van de dikke fractie (export zonder RePeat). Het break-evenpunt ligt bij een verkoopprijs van $€ 18$ per ton bodemverbeteraar. Bij afzet naar de landbouw is dit verre van haalbaar, echter bij afzet als veenvervanger is dit een meer dan realistische marktwaarde en deze afzetroute wordt de komende jaren verder uitgewerkt. Indien daarnaast ook de ontwatering van het fosfaatprecipitaat wordt verbeterd, bijvoorbeeld door toevoeging van magnesiumhydroxide aan de fosfaatprecipitatietank waarbij struviet wordt gevormd i.p.v. kalkmelk, kan de kostprijs dalen tot circa $€ 15$ per ton dikke fractie. 
Tabel 6.6 Kostenoverzicht van het RePeat-systeem op basis van de werking in 2020 (RePeat huidig) en een beoogd scenario (RePeat voorzien).

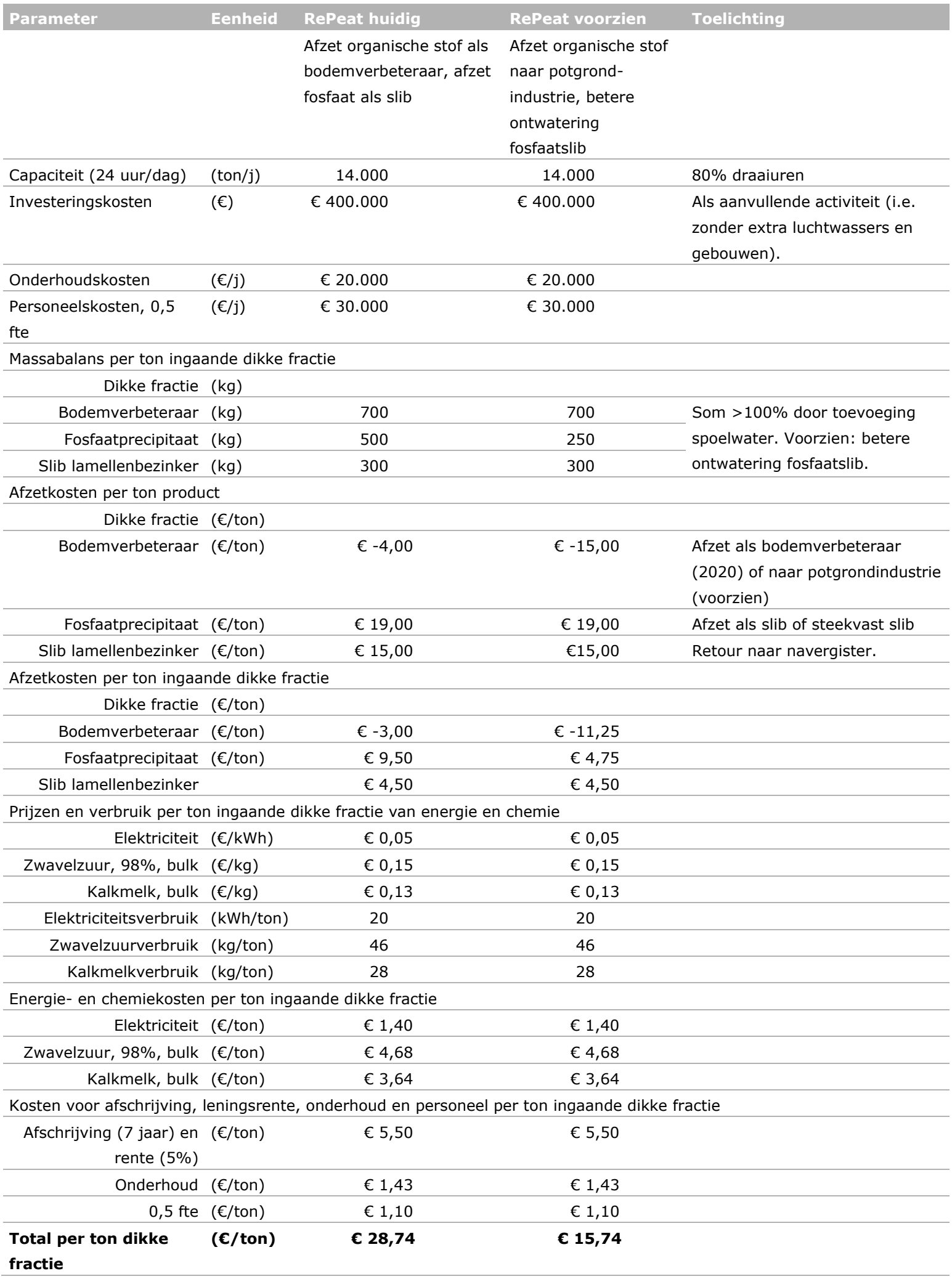




\subsection{Conclusies}

- Kosten voor mestverwerking zijn berekend voor een scenario met mestscheiding in een dikke en dunne fractie, en twee scenario's voor opwerking van mest of co-digestaat tot dikke fractie, NKconcentraat en loosbaar water.

- De kostprijzen voor verwerking van varkensdrijfmest tot een exportwaardige dikke fractie en NKconcentraat zijn berekend op $€ 19$ tot $€ 22$ per ton mest op basis van prijzen voor 2020. Opwerking van dunne fractie tot NK-concentraat geeft een voordeel voor verwerkers gelegen op relatief grote afstand van akkerbouwgebied. Indien de verwerker de dunne fractie in de nabije omgeving af kan zetten $(<50 \mathrm{~km})$, is er geen financieel voordeel van opwerking tot NK-concentraat t.o.v. afzet van dunne fractie.

- De kostprijs voor verwerking van een ton digestaat is berekend op $€ 22$ per ton digestaat. Vergelijking met de kostprijs van mestverwerking is niet mogelijk door de verwevenheid met de kosten en baten gerelateerd aan de vergisting van co-producten.

- Mogelijkheden om kosten te verlagen, zijn beperkt. Afnemers zijn bereid te betalen voor een 'meststof op maat' zoals de 'Groene Weide Meststof' van GZV, maar het voordeel hiervan op de totale businesscase is beperkt, omdat er evenwel kosten gemaakt worden voor bemonstering, opslag, transport en aanwending.

- Mestverwerking tot NK-concentraat kan bij een dalende mestprijs niet concurreren met afzet van onbewerkte mest op de binnenlandse markt, tenzij het prijsverschil wordt gecompenseerd door de waarde van VVO's of door verplichte verwerking waardoor het aanbod en daarmee het poorttarief stijgt. Bij een verdere uitwerking van plannen voor verplichte verwerking van alle nietgrondgebonden mest van veehouders (tweesporenbeleid) moet daarom ook aandacht zijn voor de financiële haalbaarheid van de plannen.

- Bij onderbenutting van de verwerkingscapaciteit neemt de kostprijs per ton mest voor de verwerker toe; een gegarandeerde aanvoer van mest naar de verwerker is cruciaal om een laag poorttarief te realiseren en investeringen mogelijk te maken.

- Verdere scheiding van dikke fractie met het RePeat-systeem in een fosfaatmeststof en een fosfaatarme bodemverbeteraar levert een financieel voordeel voor de verwerker, mits hoogwaardige afzet van de eindproducten mogelijk is, bijvoorbeeld als veenvervanger naar de potgrondindustrie of champignonteelt. 


\section{$7 \quad$ Milieukundige evaluatie}

\subsection{Inleiding}

Mestscheiding is ontstaan vanuit de noodzaak om overschotten aan mest (qua binnen de Nederlandse landbouw plaatsbare fosfaat) tegen zo laag mogelijke kosten te verwerken. De huidige verplichte mestverwerking stuurt op verwerking van dit overschot. De laatste jaren is er echter meer aandacht gekomen voor de rol van mestverwerking in het terugdringen van ammoniak- en broeikasgasemissies vanuit de landbouw. Door uitbreiding van de mestverwerkingsplicht (tweesporenbeleid) wordt beoogd om bij te dragen aan emissiereducties. Huidige mestverwerkingsinstallaties zijn niet met dat doel ontworpen en daarom is het zinvol om te evalueren hoe bestaande verwerkingsinstallaties bijdragen aan emissiereducties en waar verbeterpunten liggen. Die kennis kan benut worden bij het verder verduurzamen van de mestverwerkingssector onder het nieuwe mestbeleid.

In dit kader is er behoefte aan inzicht in effecten van mestverwerking op:

- Emissies van broeikasgassen $\left(\mathrm{CO}_{2}, \mathrm{CH}_{4}, \mathrm{~N}_{2} \mathrm{O}\right)$

- Emissies van ammoniak

In dit project zijn data verzameld van grootschalige verwerkingsinstallaties voor mest en digestaat (van co-vergiste mest). Hiermee is voor zeven scenario's, gebaseerd op de procesvoering van de deelnemende verwerkers, door middel van een levenscyclusanalyse ( $L C A$ ) de $\mathrm{CO}_{2}$-voetafdruk van de verwerkingsinstallatie berekend. In deze $\mathrm{CO}_{2}$-voetafdruk zijn de volgende posten meegenomen:

- energieverbruik mesttransport

- energieverbruik mestverwerking en hygiënisatie

- chemieverbruik mestverwerking

- besparing stikstofkunstmest

- besparing fossiele energie door biogasproductie bij vergisting

- methaanemissies uit mestkelders, mestopslagen en bij vergisting

Alle hier beschouwde verwerkingsinstallaties voor mest of digestaat zijn uniek en hun berekende $\mathrm{CO}_{2}-$ voetafdruk hangt af van locatiespecifieke keuzes en condities zoals de vergisting van co-producten, de beschikbaarheid van restwarmte uit biogasmotoren of uit nevenactiviteiten en de afstand tot het afzetgebied van de eindproducten.

Deze evaluatie heeft als het doel om scenario's met mestverwerking te vergelijken met een referentiescenario waarin het overschot aan mest ongescheiden wordt geëxporteerd. De gekozen aanpak leent zich niet om verwerkingsinstallaties onderling te vergelijken. Door verschillen in de uitgangspunten tussen de verwerkers, zoals de inname van co-producten bij co-vergistingsinstallaties, is een onderlinge vergelijking van de $\mathrm{CO}_{2}$-voetafdrukken niet te rechtvaardigen.

\subsection{Scenario's en uitgangspunten levenscyclusanalyse}

\subsubsection{Afbakening, functionele eenheid en scenario's}

Voor drie deelnemende verwerkers is op basis van in totaal zeven verwerkingsscenario's een $\mathrm{CO}_{2}$ voetafdruk berekend. Daarbij is de huidige situatie, scheiding van mest of digestaat, vergeleken met een referentiescenario waarin mest of digestaat zonder scheiding wordt geëxporteerd. Ook zijn scenario's met en zonder co-vergisting van de ingaande mest meegenomen. Figuur 7.1 geeft de afbakening van de LCA voor de $\mathrm{CO}_{2}$-voetafdruk van mestverwerkingsscenario's weer voor de situatie met en zonder co-vergisting. 


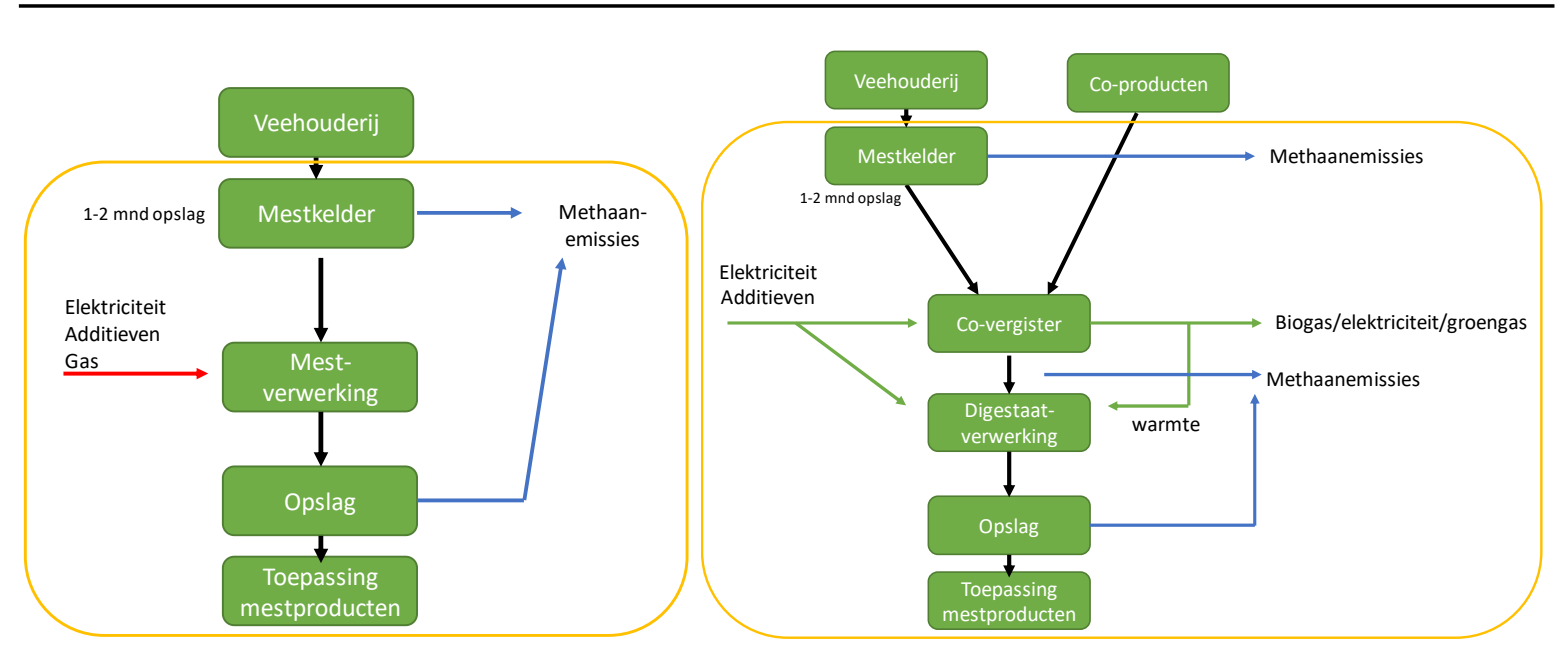

Figuur 7.1 Afbakening (gele lijn) van de levenscyclusanalyse voor de $\mathrm{CO}_{2}$-voetafdruk van mestverwerkingsscenario's zonder (links) en met co-vergisting (rechts).

Tabel 7.1 geeft een korte omschrijving van de zeven scenario's voor de berekening van de $\mathrm{CO}_{2}$ voetafdruk van verwerking van mest of digestaat van co-vergisting. Van Amstel verwerkt onvergiste mest terwijl Dekker en GZV co-vergiste mest (digestaat) verwerken. Bij die laatste twee is er verstrengeling van twee bedrijfsactiviteiten, namelijk vergisting van co-producten en verwerking van mest. Deze activiteiten kunnen niet los van elkaar beschouwd worden en daarom is de $\mathrm{CO}_{2}$-voetafdruk voor de scenario's van Dekker en GZV opgesteld per ton digestaat. Voor het scenario voor Van Amstel is de $\mathrm{CO}_{2}$-voetafdruk opgesteld per ton mest en hierdoor kunnen de scenario's voor Van Amstel niet vergeleken worden met die voor Dekker en GZV. 
Tabel 7.1 Omschrijving van de scenario's voor de berekening van de $\mathrm{CO}_{2}$-voetafdruk van verwerking van mest of digestaat van co-vergisting. Scenario's A1, B1 en C2 zijn referentiescenario's waarin drijfmest of co-vergistingsdigestaat zonder scheiding wordt geëxporteerd.

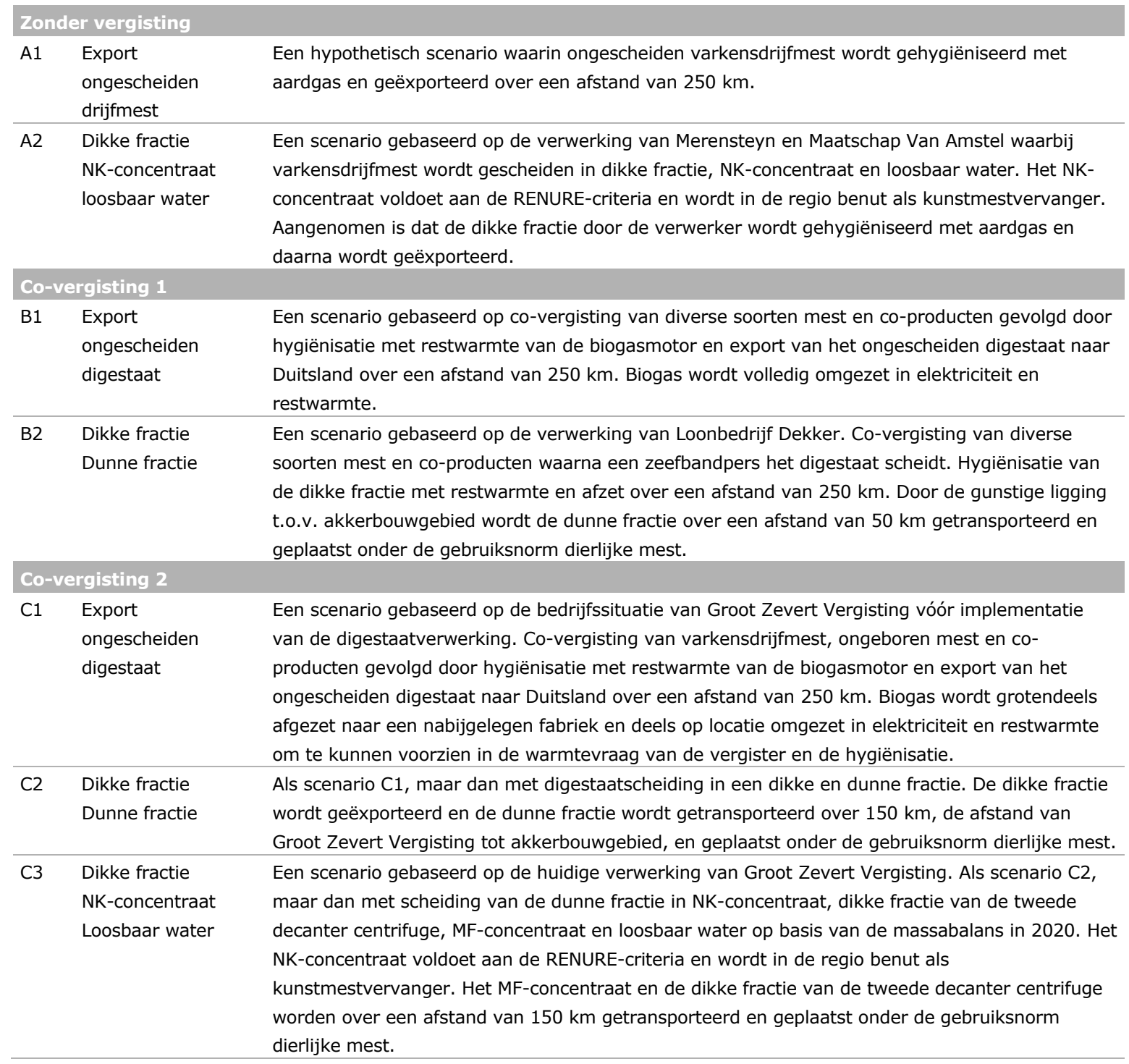

\subsubsection{Massabalansen}

Tabel 7.2 toont de gehanteerde massabalansen voor de scenario's voor de berekening van de $\mathrm{CO}_{2}$ voetafdruk van verwerking van mest of digestaat van co-vergisting. Deze massabalansen zijn gebaseerd op de opgestelde massabalansen voor de gemonitorde verwerkers (hoofdstuk 3). Voor iedere verwerker is de berekende $\mathrm{CO}_{2}$-voetafdruk voor de huidige procesvoering vergeleken met een referentiescenario waarin de mest of het digestaat zonder scheiding wordt geëxporteerd.

Tabel 7.2 Gehanteerde massabalansen in $\mathrm{kg}$ per ton ingaande mest of digestaat voor de scenario's voor de berekening van de $\mathrm{CO}_{2}$-voetafdruk van verwerking van mest of digestaat van co-vergisting. Scenario's A1, B1, C1 zijn de referentiescenario zonder scheiding van de drijfmest of digestaat.

\begin{tabular}{|c|c|c|c|c|c|c|c|}
\hline & A1 & A2 & B1 & B2 & C1 & C2 & C3 \\
\hline Digestaat & & & 100 & & 1000 & & \\
\hline Dunne fractie & & & & 800 & & 850 & \\
\hline Microfiltratieconcentraat & & & & & & & 370 \\
\hline Loosbaar water & & 520 & & & & & 180 \\
\hline
\end{tabular}




\subsubsection{Transportafstanden}

Tabel 7.3 toont de gehanteerde transportafstanden voor aanvoer van mest naar de verwerker en afvoer van de eindproducten voor de berekening van de $\mathrm{CO}_{2}$-voetafdruk. De $\mathrm{CO}_{2}$-emissiefactor voor een Euro 5-vrachtwagen met een laadcapaciteit van 27 ton is gehanteerd (GABI-database), waarbij is aangenomen dat de vrachtwagen zonder retourvracht terug rijdt.

Tabel 7.3 Gehanteerde transportafstanden (in $\mathrm{km}$ ) voor aanvoer van mest naar de verwerker en afvoer van de eindproducten voor de berekening van de $\mathrm{CO}_{2}$-voetafdruk van verwerking van mest of digestaat van co-vergisting.

\begin{tabular}{l|ll} 
Omschrijving & Afstand & Toelichting \\
Aanvoer naar verwerker & 15 & Mest wordt opgehaald bij veehouders binnen een straal van 25 km. \\
\hline Ongescheiden mest/digestaat & 250 & Afzet van ongescheiden mest of digestaat naar Duitsland. \\
\hline Dikke fractie & 300 & Afzet naar Noord-Frankrijk of Duitsland. \\
\hline NK-concentraat & 25 & Afzet binnen $25 \mathrm{~km}$ van de verwerker. \\
\hline Dunne fractie & 150 of 50 & $\begin{array}{l}\text { Afzet naar de akkerbouw onder de gebruiksnorm dierlijke mest, 150 km } \\
\text { voor scenario C2 en } 50 \mathrm{~km} \text { voor scenario B2. }\end{array}$ \\
\hline Concentraat microfiltratie & 150 & Afzet naar de akkerbouw onder de gebruiksnorm dierlijke mest.
\end{tabular}

\subsubsection{Energieproductie en verbruik}

De $\mathrm{CO}_{2}$-emissie van energieverbruik en vermeden $\mathrm{CO}_{2}$-emissie van energieproductie zijn als volgt berekend:

- 0,396 $\mathrm{kg} \mathrm{CO}_{2} / \mathrm{kWh}$ elektriciteit (als energiemix Europa o.b.v. de GABI-database);

- $0,228 \mathrm{~kg} \mathrm{CO} / \mathrm{kWh}$ aardgas of biogas (als aardgas o.b.v. de GABI-database);

- aan restwarmte van de biogasmotoren is geen $\mathrm{CO}_{2}$-emissie toegeschreven.

Het energieverbruik van de deelnemende verwerkingsinstallaties is opgevraagd en omgerekend naar $\mathrm{kWh}$ elektrische en thermische energie per ton verwerkte mest of digestaat. Indien nodig is een schatting gehanteerd of is op basis van een schatting een verdeling gemaakt van het verbruik over de vergister en de verwerkingsinstallatie.

In scenario A1 vindt geen scheiding plaats en wordt daarom weinig elektriciteit verbruikt; er is een kleine post opgenomen voor het mixen van de mest tijdens de opslag (Van Dijk et al., 2015). Voor scenario A2 is het elektriciteitsverbruik circa $15 \mathrm{kWh} /$ ton mest. Het elektriciteitsverbruik van Dekker is gehanteerd voor scenario's B. Het totale verbruik van de locatie van Dekker (vergistingsinstallatie en verwerkingsinstallatie inclusief nevenactiviteiten) is bekend en gehanteerd in scenario B2. Het verbruik van de vergistingsinstallatie (scenario $B 1$ ) is berekend door het geschatte elektriciteitsverbruik van de zeefbandpers ( $4 \mathrm{kWh}$ /ton mest) af te trekken van het totale elektriciteitsverbruik. Voor scenario's $C$ is het elektriciteitsverbruik van GZV gehanteerd, gebaseerd op het jaarverbruik van GZV, aangevuld met 24 uursmetingen voor individuele scheidingsapparaten. In scenario $\mathrm{C} 1$ is dit het verbruik van de vergistingsinstallatie inclusief randzaken en in scenario C3 het verbruik van het GENIAAL-systeem. Voor scenario C2, alleen scheiding in dikke en dunne fractie met een enkele decanter centrifuge, is voor deze scheiding uitgegaan van een elektriciteitsverbruik van $9 \mathrm{kWh} /$ ton digestaat. Van Dijk et al. (2015) hanteren in een eerdere LCA een elektriciteitsverbruik van $11 \mathrm{kWh}$ per verwerkte ton voor scheiding met een decanter centrifuge en $25 \mathrm{kWh}$ per verwerkte ton voor scheiding in dikke fractie, NK-concentraat en loosbaar water. Deze waarden zijn vergelijkbaar met de hier gehanteerde verbruikswaarden. Voor de acht verwerkers van de pilot mineralenconcentraten (De Vries et al., 2011) zijn voor scheiding in dikke fractie, NK-concentraat en loosbaar water echter lagere verbruikswaarden gerapporteerd van 9,0 kWh per ton verwerkte mest. Het is onduidelijk waarom het destijds gerapporteerde elektriciteitsverbruik zo sterk afwijkt van het verbruik van de hier geëvalueerde verwerkers.

Tabel 7.4 toont het aandeel van de ingaande stromen op massabasis, de biogasproductie, de energielevering en het energieverbruik voor de verschillende scenario's. De biogasproductie en daaruit 
geproduceerde energie zijn opgenomen conform de door Dekker (scenario's B) en GZV (scenario's C) beschikbaar gestelde gegevens. Dekker zet al het geproduceerde biogas om in elektriciteit en restwarmte. GZV zet het overgrote deel van het biogas, na ontzwaveling, rechtstreeks af naar een nabijgelegen zuivelfabriek, wat resulteert in een hogere benutting van de energiewaarde van het biogas. Op basis van het methaangehalte is de hoeveelheid geproduceerd biogas omgerekend naar aardgasequivalenten met gebruikmaking van de calorische waarde van methaan $\left(10,25 \mathrm{kWh} / \mathrm{m}^{3} \mathrm{CH}_{4}\right)$.

$\mathrm{Bij}$ berekening van de vermeden $\mathrm{CO}_{2}$-emissie door productie van energie uit biogas is onderscheid gemaakt tussen de biogasproductie uit drijfmest (exclusief ongeboren mest) en die uit co-producten en ongeboren mest. Uitgegaan is van een geschatte productie van $13 \mathrm{~m}^{3} \mathrm{CH}_{4}$ /ton drijfmestmest ( $23 \mathrm{~m}^{3}$ biogas/ton drijfmest). Het overige deel van de biogasproductie is toegekend aan de coproducten en ongeboren mest. GZV voegt een type co-producten met een hogere energiewaarde per ton toe vanwege een hoger drogestofgehalte. Daardoor is de biogasproductie voor GZV, uitgedrukt in $\mathrm{m}^{3}$ methaan per ton digestaat, aanzienlijk hoger dan voor Dekker.

In scenario A1 wordt alle drijfmest gehygiëniseerd met aardgas. In scenario A2 wordt de dikke fractie met aardgas gestookte infraroodlampen gehygiëniseerd waarbij circa $29 \mathrm{kWh}$ aardgas per ton ingaande drijfmest wordt verbruikt. In scenario's B1 en B2 wordt, conform de procesvoering van Dekker, de dikke fractie gehygiëniseerd met een deel van de restwarmte van de biogasmotor. Ook wordt in scenario's B1 en B2 een deel van de restwarmte verbruikt voor verwarming van de vergister.

Het voor deze scenario's getoonde verbruik aan restwarmte is het totale thermische energieverbruik van de locatie. In de zomer blijft vanwege de hogere buitentemperaturen een deel van de restwarmte onbenut. In scenario $\mathrm{C}$ is het restwarmteverbruik conform de procesvoering van GZV; hygiënisatie vindt plaats in de navergister door de temperatuur te verhogen van $40^{\circ} \mathrm{C}$ naar $52^{\circ} \mathrm{C}$. Deze methode profiteert van de hogere temperatuur die het te hygiëniseren digestaat vanwege het vergistingsproces al heeft. Het totale warmteverbruik inclusief verwarming van de vergisters is circa $44 \mathrm{kWh}$ per ton digestaat voor scenario's C1, C2 en C3. Naar schatting wordt circa 50\% hiervan gebruikt voor de hygiënisatie. In de zomer blijft ook hier vanwege de hogere buitentemperaturen een deel van de restwarmte onbenut. In de winter wordt indien nodig bijgestookt met biogas, de hoeveelheid hiervan is onbekend en is niet meegenomen in de berekeningen.

Tabel 7.4 Aandeel ingaande stromen op massabasis, biogasproductie, energielevering en energieverbruik voor de scenario's voor de berekening van de $\mathrm{CO}_{2}$-voetafdruk voor verwerking van mest of digestaat van co-vergisting.

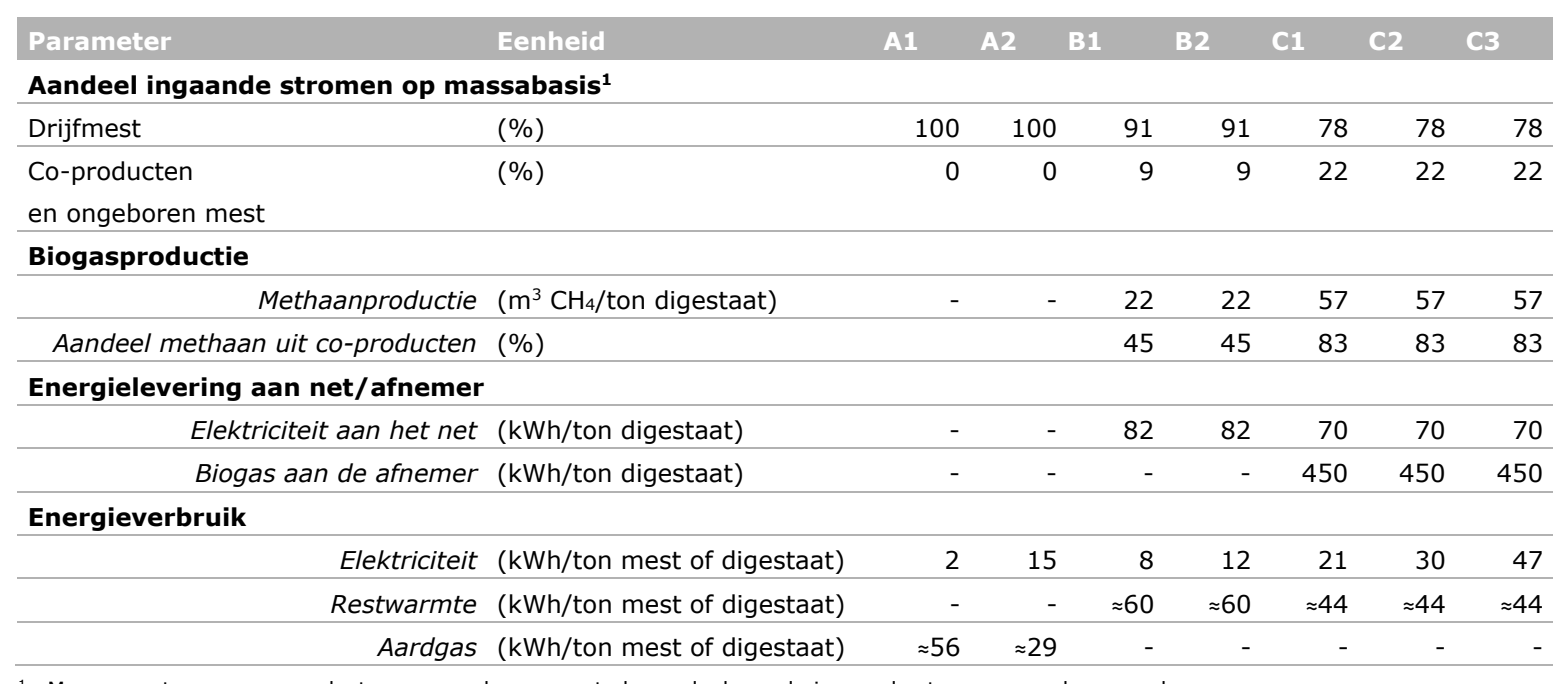

1 Massa mest versus co-producten en ongeboren mest als aandeel van de ingaande stromen van de verwerker. 


\subsubsection{Chemieverbruik}

Op basis van het door de verwerkers opgegeven, en indien nodig berekende, chemieverbruik (zwavelzuur, polymeer, ijzersulfaat etc.) van de verwerkingsinstallaties zijn de $\mathrm{CO}_{2}$-emissies voor de productie van deze chemie afgeleid. Echter, vanwege de grote onzekerheden in de emissiefactoren voor de chemieproductie en omdat de bijdrage van de chemieproductie aan de totale $\mathrm{CO}_{2}$-emissie per ton verwerkte mest minder dan $10 \%$ is, is besloten om deze niet op te nemen in de berekening.

\subsubsection{Bespaarde productie van stikstofkunstmest}

De herwonnen meststoffen (eindproducten) worden benut in de landbouw en daarmee wordt gebruik van stikstofkunstmest vermeden. Dit geldt zowel voor NK-concentraat als voor andere stikstofhoudende meststoffen zoals digestaat, dunne fractie en dikke fractie. Tabel 7.5 toont de gehanteerde forfaitaire werkingscoëfficiënten voor stikstof in drijfmest en mestproducten voor berekening van de hoeveelheid vermeden stikstofkunstmest. Die hoeveelheid is berekend als de werkingscoëfficiënt van de meststof maal het stikstofgehalte in de meststof. De werkelijke gehalten aan stikstof in de eindproducten (hoofdstuk 3 en 5) zijn daarbij gehanteerd. Per scenario is berekend hoeveel werkzame stikstof als herwonnen meststof naar de landbouw wordt afgezet per ton mest of digestaat. De vermeden stikstof is opgenomen voor alle meststoffen, omdat ook gebruik van een dunne fractie of digestaat - onder de gebruiksnorm dierlijke mest - bijdraagt aan de voorziening van de stikstofbehoefte van landbouwgronden en daarmee kunstmest vermijdt ten opzichte van een scenario waarin geen mest beschikbaar zou zijn (door bijvoorbeeld beluchte biologische afbraak of door verbranding). Bovendien is het vanuit het oogpunt van broeikasgasemissies niet relevant of de besparing binnen of buiten Nederland gerealiseerd wordt. Vanuit een politiek oogpunt is echter wel relevant welke besparing binnen de Nederlandse landbouw wordt gerealiseerd vanwege het behalen van reductiedoelstellingen. In dat geval is de besparing door toepassing van NK-concentraat als kunstmestvervanger - boven op de gebruiksnorm dierlijke mest - relevant. In de LCA is de besparing door toepassing van NK-concentraat en overige meststoffen apart weergegeven.

De $\mathrm{CO}_{2}$-emissiefactor voor kunstmestproductie is overgenomen uit de GABI-database en bedraagt $3,45 \mathrm{~kg} \mathrm{CO} 2 / \mathrm{kg} \mathrm{N}$ voor de productie van CAN (calciumammoniumnitraat/kalkammonsalpeter). Het JRC hanteert in de SAFEMANURE-studie een waarde van $3,0 \mathrm{CO}_{2} / \mathrm{kg} \mathrm{N}$, uitgaande van een toekomstig energieverbruik na verdere optimalisatie van het productieproces (Huygens et al., 2020).

Tabel 7.5 Gehanteerde forfaitaire werkingscoëfficiënten voor stikstof in drijfmest en mestproducten voor berekening van de hoeveelheid vermeden stikstofkunstmest.

\begin{tabular}{lrl}
$\begin{array}{l}\text { Meststof } \\
\text { Digestaat, drijfmest en } \\
\text { microfiltratieconcentraat }\end{array}$ & $70 \%$ & Toelichting \\
\hline Dunne fractie & $90 \%$ & \\
\hline NK-concentraat & $100 \%$ & Bij gebruik als kunstmestvervanger \\
\hline Dikke fractie & $55 \%$ & \\
\hline
\end{tabular}

\subsubsection{Methaanemissies}

Methaan is een zeer sterk broeikasgas, elke $\mathrm{kg}$ heeft een broeikasgaswerking equivalent aan $25 \mathrm{~kg}$ $\mathrm{CO}_{2}$. Emissies van methaan in de landbouw ontstaan door pens- en darmfermentatie bij vee (enterische methaanproductie) en fermentatieprocessen door methanogene bacteriën in opgeslagen dierlijke mest of producten daarvan. Methaanemissie uit de pens is vooral relevant bij herkauwers. Voor varkens zijn emissies tijdens de opslag van mest of producten daarvan de voornaamste bron van methaan. Daarnaast kunnen methaanverliezen ontstaan bij vergisting.

In deze LCA is een schatting gemaakt van methaanemissies uit de volgende bronnen:

- Methaanemissies uit de drijfmestkelder bij een reguliere opslagduur ( 6 maanden) en een korte opslagduur (1-2 maanden). 
- Methaanemissies bij opslag van drijfmestproducten na vergisting en/of scheiding.

- Methaanemissies door lekverliezen bij vergisting van drijfmest.

Methaanemissies die optreden tijdens de aanwending van de mestproducten zijn indirect in deze inschatting inbegrepen, omdat deze methaan al tijdens de opslag is gevormd.

\subsubsection{Emissies uit mestopslagen voor varkensdrijfmest}

Er zijn onzekerheden in de hoogte van methaanemissiefactoren voor de opslag van drijfmest. Aanpassingen in het rantsoen van vee kunnen leiden tot veranderingen in de mestsamenstelling inclusief het gehalte aan vluchtige vetzuren en daardoor tot veranderingen in de methaanemissie. Daarnaast is de grootte van de methaanemissie afhankelijk van de opslagtemperatuur en de opslagduur. Uit metingen onder laboratoriumcondities blijkt bijvoorbeeld dat methaanemissies uit varkensdrijfmest pas bij opslagtemperaturen boven de $15^{\circ} \mathrm{C}$ significant worden (Sommer et al., 2007). De emissiemodellen NEMA en INITIATOR hanteren emissiefactoren per diercategorie uitgaande van een gemiddelde opslagduur van mest van zes maanden. Voor varkensmest is deze emissiefactor $3,009 \mathrm{~kg} \mathrm{CH}_{4}$ per $\mathrm{m}^{3}$ mest wat neerkomt op circa 8,0 $\mathrm{kg} \mathrm{CH}$ per vleesvarken per jaar en $23 \mathrm{~kg} \mathrm{CH}_{4}$ per zeug per jaar (Van Bruggen et al., 2018; emissiefactoren o.b.v. Groenestein et al., 2016). Methaan dat emitteert ná aanwending van de mest, of een product daarvan, is al tijdens de opslag ervan gevormd en inbegrepen bij de opslagemissies.

Om de verwerkingsscenario's die scheiding bevatten ( $A 2, B 2, C 2$ en $C 3$ ) door te kunnen rekenen, is een inschatting nodig van de methaanemissies uit de drijfmestopslag van de veehouder in de periode voor afvoer naar de verwerker. Hiervoor is aangenomen dat de drijfmest maandelijks wordt opgehaald bij de varkenshouder en dat in het referentiescenario zonder mestscheiding de drijfmest voor vier tot zes maanden wordt opgeslagen. Uit gesprekken met verwerkers blijkt dat maandelijks afvoeren van drijfmest het geval is voor varkenshouders die hun drijfmest onder een contract afvoeren. Daarnaast zijn er ook varkenshouders die drijfmest in de eigen mestkelder opslaan en wachten tot de mestprijzen gunstig zijn. Hoe de methaanemissies veranderen onder invloed van opslagduur is onzeker. Sommers et al. (2007) hebben metingen uitgevoerd (laboratoriumcondities) met geïnoculeerde varkensdrijfmest en tonen aan dat de methaanflux over een periode van vijf maanden ongeveer constant blijft. Gollenbeek et al. (2021) hebben een modelmatige aanpak gehanteerd waaruit volgt dat een opslagduur van één of twee maanden resulteert in respectievelijk $66 \%$ en $33 \%$ reductie van de methaanemissies t.o.v. reguliere opslag gedurende vier tot zes maanden en dit is overgenomen in deze studie.

Om effecten van mestscheiding op de methaanemissie te berekenen, is daarnaast een emissiefactor voor de eindproducten nodig. Emissiefactoren voor methaan zijn afgeleid door Groenestein et al. (2016) voor varkensdrijfmest $\left(0,073 \mathrm{~kg} \mathrm{CH}_{4} / \mathrm{kg}\right.$ organische stof) en vaste mest $(0,0041 \mathrm{~kg} \mathrm{CH} / \mathrm{kg}$ organische stof). Bij vaste mest is het risico op methaanemissies aanzienlijk lager dan bij drijfmest, omdat vaste mest (stapelbaar) niet voldoende anaeroob wordt om methaanproductie op gang te brengen. Deze redenatie is ook van toepassing op dikke fractie na hoogwaardige mestscheiding (Mosquera et al., 2010), daarom is aangenomen dat deze emissiefactor voor vaste mest ook van toepassing is op dikke fractie. Voor dunne fractie en NK-concentraat wordt de emissiefactor voor varkensdrijfmest gehanteerd, omdat deze mestproducten anaeroob worden. Door het lagere organischestofgehalte in dunne fractie en NK-concentraat is de emissie per ton mestproduct echter aanzienlijk lager dan voor varkensdrijfmest. Indien vergisting wordt toegepast, is er geen risico meer op methaanemissie bij opslag van het digestaat of de daaruit geproduceerde scheidingsproducten (Groenestein et al., 2016).

Op basis van gemiddelde organischestofgehalten in de eindproducten is de methaanemissie berekend uitgaande van een korte opslagduur (één maand) van mest gevolgd door scheiding in dikke fractie en NK-concentraat (Tabel 7.6). Omdat dunne fractie in onze studie een gelijk organischestofgehalte heeft als NK-concentraat is de berekening ook daarop van toepassing. De hier berekende emissiefactoren gelden voor scheiding waarbij een dikke fractie met een drogestofgehalte van circa $30 \%$ ontstaat. Indien een laagwaardigere scheiding wordt uitgevoerd waarbij een verpompbare dikke fractie wordt geproduceerd, is er geen voordeel qua methaanemissies en gelden de emissiefactoren zoals gerapporteerd door Melse en Groenestein (2016). 
Tabel 7.6 Uitgangspunten berekening methaanemissie uit mestopslagen bij een reguliere opslagduur voor varkensdrijfmest en bij korte opslagduur gevolgd door scheiding of vergisting. ${ }^{1}$

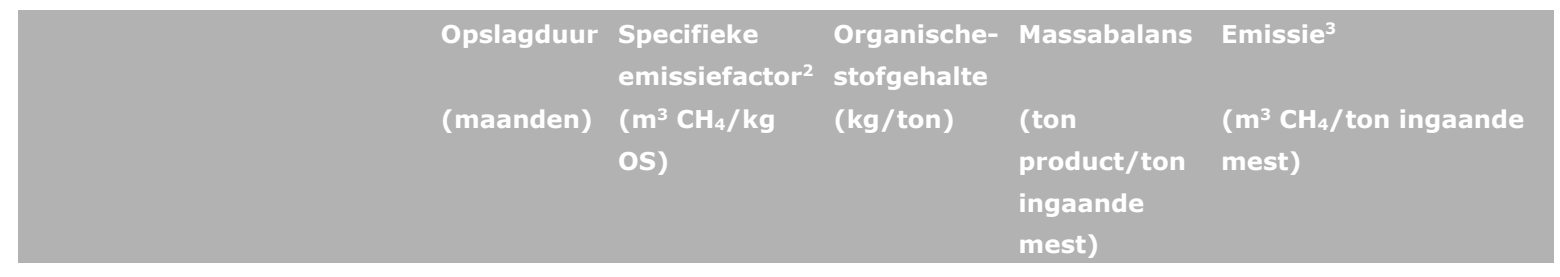

\section{Reguliere opslagduur}

$\begin{array}{llll}\text { Varkensdrijfmest } & 4 \text { tot } 6 & 0,112 & 5,6\end{array}$

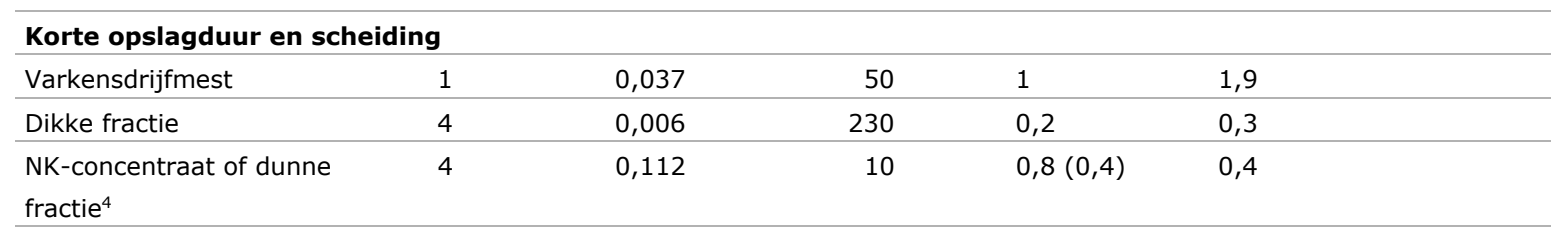

Totaal

2,6 (vermeden: 3,0)

\section{Korte opslagduur en vergisting}

\begin{tabular}{llllll}
\hline Varkensdrijfmest & 1 & 0,037 & 50 & 1 & 1,9 (vermeden: 3,7 ) \\
\hline Digestaat(producten) & 4 & 0 & - & 0 & 0 \\
\hline
\end{tabular}

1 Zie tekst boven deze tabel voor aannames en bronnen.

2 Methaanproductie in $\mathrm{m}^{3}$ per $\mathrm{kg}$ organische stof in de opgeslagen meststof. Voor varkensdrijfmest bij een opslagduur van één maand is $33 \%$ van de specifieke emissiefactor voor een opslagduur van zes maanden gehanteerd.

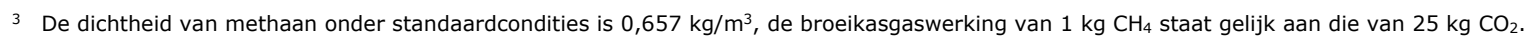

4 De berekening geldt zowel voor een situatie met NK-concentraat en dunne fractie na hoogwaardige scheiding, omdat de massa organische stof in het mestproduct na scheiden leidend is voor de methaanemissie. Bij een NK-concentraat gaat een gelijke hoeveelheid organische stof naar het eindproduct, zij het in een meer geconcentreerde vorm, ten opzichte van dunne fractie.

\subsubsection{Emissies bij co-vergisting van varkensdrijfmest}

Bij mestvergisting kunnen methaanemissies voorkomen door o.a. lekverliezen uit de vergister en biogasleidingen en verliezen bij de verbranding van biogas. Tabel 7.7 toont de uitgangspunten voor de berekening van methaanemissies bij co-vergisting van varkensdrijfmest en verwerking van het geproduceerde digestaat. Overeenkomstig emissiemodellen is aangenomen dat $1 \%$ van het geproduceerde methaan door lekverliezen verloren gaat (Kros et al., 2018). Er is grote onzekerheid over de werkelijke lekverliezen van methaan uit vergistingsinstallaties. Melse en Groenestein (2016) hanteren een lekverlies van $4,3 \%$ van het geproduceerde methaan op basis van metingen aan een tiental vergisters in Denemarken. Uit een Deense studie blijkt dat er grote verschillen zijn tussen vergistingsinstallaties in het aantal gedetecteerde lekpunten en de grootte van de lekverliezen daaruit (Jorgensen and Kvist, 2015). Tevens laat die studie zien dat het nemen van maatregelen effectief is om lekverliezen te voorkomen. $\mathrm{Na}$ aanpassingen was het gemiddelde lekverlies op de tien bedrijven gedaald van $4,3 \%$ naar $0,8 \%$ van de methaanproductie. De aanname van $1 \%$ van de methaanproductie als lekverlies, zoals hier gehanteerd, is dus van toepassing op een vergistingsinstallatie waar vermijdbare lekverliezen worden voorkomen. Overeenkomstig Melse en Groenestein (2016) is aangenomen dat er bij de opslag van digestaat - of scheidingsproducten daaruit - geen methaanemissies voorkomen. Eventuele emissies bij opslag van digestaat zijn inbegrepen in het lekverlies van $1 \%$ van de methaanproductie. De LCA is opgesteld per ton digestaat, daarom is het lekverlies berekend over de totale biogasproductie inclusief de bijdrage vanuit co-producten. 
Tabel 7.7 Uitgangspunten berekening methaanemissies bij co-vergisting van varkensdrijfmest en verwerking van het geproduceerde digestaat.

\begin{tabular}{|c|c|c|c|c|}
\hline Scenario's & $\begin{array}{l}\text { Vermeden emissies } \\
\text { mestopslag }^{1} \\
\text { ( } \mathrm{m}^{3} \mathrm{CH}_{4} / \text { ton mest) }\end{array}$ & $\begin{array}{l}\text { Specifieke } \\
\text { methaanproductie } \\
\text { vergisting } \\
\text { (kg CH} 4 / \text { ton digestaat) }\end{array}$ & $\begin{array}{l}\text { Emissies door } \\
\text { lekverliezen } \\
(-)\end{array}$ & $\begin{array}{l}\text { Emissie digestaatopslag }{ }^{2} \\
\text { (kg CH} 4 / \text { ton digestaat) }\end{array}$ \\
\hline Co-vergisting 1 en 2 & 3,7 (Tabel 7.6) & $\begin{array}{l}\text { Volgens opgave } \\
\text { verwerker, inclusief co- } \\
\text { producten. }\end{array}$ & $\begin{array}{l}1 \% \text { van de } \\
\text { methaanproductie }\end{array}$ & Geen \\
\hline
\end{tabular}

1 Vermeden emissies door de opslagduur van varkensdrijfmest bij de veehouder te verlagen van 6 maanden naar 1 maand (Tabel 7.6). Voor de toepassing zijn de verwerkingsscenario's in dit geval omgerekend naar kg geproduceerd $\mathrm{CH}_{4}$ per ton digestaat o.b.v. het aandeel mest versus co-producten in het rantsoen van de vergister.

2 Emissies voor opslag van digestaat of scheidingsproducten daaruit; voor beide is aangenomen dat deze niet voorkomen.

\subsubsection{Ammoniakemissies}

Voor ammoniakemissies uit mest zijn de volgende bronnen aan te wijzen:

- Stalemissies

- Emissies tijdens de verwerking en opslag van mestproducten

- Aanwendingsemissies

In 2018 bedroeg de totale ammoniakemissie gerelateerd aan de Nederlandse varkenshouderij 18,8 miljoen $\mathrm{kg} \mathrm{N}$, waarvan 12,0 miljoen $\mathrm{kg}$ uit stalemissies, 6,2 miljoen $\mathrm{kg}$ uit mestaanwending en 0,6 miljoen kg uit mestverwerking (Van Bruggen et al., 2021).

Door mestverwerking wordt de opslagduur van mest in de mestkelder verkort. Op basis van beschikbare kennis is het effect hiervan op de ammoniakemissies uit de stal beperkt. Dit wordt in het kader van andere projecten, waaronder 'NL Next Level Mestverwaarding', verder onderzocht.

\subsubsection{Emissies tijdens verwerking en opslag}

Metingen van emissies tijdens de verwerking en opslag van mestproducten zijn niet of nauwelijks beschikbaar en de gemeten waarde is afhankelijk van locatiespecifieke factoren, zoals het functioneren van afzuigingen en luchtwassers. De werkelijke emissiegrootte uit die bronnen is daardoor niet bekend en kan slechts op hoofdlijnen worden geraamd. In deze studie zijn voor de opgestelde massabalansen voor scheiding, hygiënisatie en opwerking tot NK-concentraat geen aantoonbare verliezen van $\mathrm{N}-\mathrm{NH}_{4}$ geconstateerd (hoofdstuk 3). Ook Hoeksma (2011) rapporteert voor de monitoring van de pilotbedrijven en de daaruit afgeleide massabalansen geen verliezen van $\mathrm{N}$ of $\mathrm{NH}_{4}$ die de onzekerheidsmarge van de gehanteerde methode overschrijden. De onzekerheidsmarge in massabalansen is echter, afhankelijk van de manier van opstellen, relatief groot, waardoor verliezen van minder dan $10 \%$ niet vastgesteld kunnen worden. De hier uitgevoerde evaluatie gaat over industriële mestverwerkers waar alle scheidingsapparaten en de mestopslag zich in afgesloten ruimtes bevinden die voorzien zijn van afzuigingssystemen die zijn aangesloten op luchtwassers. Daarom wordt hier verondersteld dat er geen ammoniakemissies naar de buitenlucht plaatsvinden.

\subsubsection{Aanwendingsemissies}

In het Besluit Gebruik Meststoffen staat dat dierlijke meststoffen emissiearm moeten worden toegediend en deze voorwaarden gelden ook voor nieuwe mestproducten die zijn gebaseerd op dierlijke mest. Voor RENURE-materiaal is eveneens een plicht tot emissiearme aanwending voorzien.

Voor grasland geldt:

- Drijfmest dient direct in de grond gebracht te worden (zodebemesting). Het gebruik van een sleepvoet waarbij mest tussen het gras wordt uitgereden, is sinds 2019 verboden, tenzij de mest met water wordt verdund.

- Vaste dierlijke meststoffen hoeven op grasland niet emissiearm te worden toegediend. 
Voor bouwland geldt:

- Drijfmest op beteeld en onbeteeld bouwland dient in alle gevallen direct in de grond te worden gebracht. Bij onbeteeld bouwland moeten de sleufjes $5 \mathrm{~cm}$ diep zijn (mestinjectie).

- Vaste mest op bouwland dient in maximaal twee direct opeenvolgende werkgangen te worden ondergewerkt.

Tabel 7.8 toont de ammoniakemissiefactoren voor aanwending van drijfmest, NK-concentraat, dikke fractie van mest, vaste mest en kunstmest. De emissiefactoren voor aanwending van varkensdrijfmest en vaste varkensmest zijn overgenomen uit het rekenmodel voor de nationale emissieregistratie (Van Bruggen et al., 2021). Emissiefactoren worden uitgedrukt als percentage van het totaal ammoniakaal stikstof (TAN) of als percentage van het totaalstikstof (N). Voor aanwending van drijfmest is er een groot verschil in emissiefactoren voor aanwending op grasland (17\% van TAN) en aanwending op bouwland met mestinjectie ( $2 \%$ van TAN). Voor de dikke fractie van varkensmest is conform het advies van de Commissie Deskundigen Meststoffenwet (CDM) aangenomen dat de emissiefactor gelijk is aan die voor vaste varkensmest.

Data over ammoniakemissies bij aanwending van mestproducten van hoogwaardige verwerking, waaronder NK-concentraat, zijn schaars. Omdat NK-concentraat, net als drijfmest, een hoog gehalte $\mathrm{N}-\mathrm{NH}_{4}$ en een $\mathrm{pH}$ boven de 7,5 heeft, is er risico op ammoniakemissies bij niet-emissiearme aanwending. De hier gehanteerde emissiefactor voor NK-concentraat is afgeleid op basis van een eerder advies van de CDM (CDM, 2013), waarin de ammoniakemissies uit NK-concentraat modelmatig zijn vastgesteld met het Alfam-model. Deze emissiefactor is $50 \%$ lager dan de emissiefactor voor aanwending van onbewerkte drijfmest met zodebemesting op grasland of bouwland. De lagere ammoniakemissiefactor voor aanwending van NK-concentraat t.o.v. drijfmest wordt verklaard door de lagere viscositeit van NK-concentraat, waardoor de meststof sneller in de bodem infiltreert. Een lagere emissiefactor voor aanwending van NK-concentraat t.o.v. drijfmest is in lijn met metingen van ammoniakemissies. Velthof en Hummelink (2011) stelden onder laboratoriumcondities vast dat aanwendingsemissies per $\mathrm{kg} \mathrm{N}-\mathrm{NH}_{4}$ in de meststof lager zijn voor NK-concentraat dan voor drijfmest. De spreiding in de gemeten waarden was echter groot. Huijsmans en Hol (2011) bepaalden aanwendingsemissies voor NK-concentraat onder veldomstandigheden en rapporteerden een circa $50 \%$ lagere emissiefactor (als percentage van TAN) ten opzichte van onbewerkte mest voor beteeld bouwland (sleepslangbemester en zodebemester) en een reductie van 30\% ten opzichte van onbewerkte drijfmest voor grasland (zodebemesting). De metingen zijn echter slechts over één groeiseizoen uitgevoerd en de variatie tussen de metingen was groot.

Zoals hierboven toegelicht, is de afgeleide emissiefactor voor aanwending van NK-concentraat op grasland (ondiepe injectie/zodebemesting) en beteeld bouwland (injectie via sleufjes in de grond) vastgesteld op 50\% van de emissiefactor voor aanwending van drijfmest. Bij aanwending op onbeteeld bouwland (via direct gedichte $>5 \mathrm{~cm}$ diepe sleufjes) is aangenomen dat de emissiefactor voor drijfmest ( $2 \%$ van TAN) ook van toepassing is op NK-concentraat. Dit omdat er bij aanwending via sleufjes in de grond, ongeacht de viscositeit van de meststof, nauwelijks emissies plaatsvinden. De in Tabel 7.8 getoonde emissiefactoren voor aanwending van NK-concentraat zijn niet van toepassing wanneer NK-concentraat wordt bijgemengd bij drijfmest, wat onder de huidige wetgeving is toegestaan. In dat geval mag verondersteld worden dat de emissiefactor voor drijfmest van toepassing is vanwege de hogere viscositeit van het mengsel t.o.v. ongemengd NK-concentraat.

Voor aanwending van dunne fractie van mest zijn geen emissiefactoren bekend. De term dunne fractie wordt in de praktijk gebruikt voor de resulterende vloeistof van zowel laagwaardige scheiding (schroefpers) als hoogwaardige scheiding (zeefbandpers, decanter centrifuge) en de manier van scheiden is van invloed op de viscositeit en de emissiefactor van de dunne fractie. 
Tabel 7.8 Ammoniakemissiefactoren voor aanwending van drijfmest, NK-concentraat, dikke fractie van mest en vaste mest als \% van totaal ammoniakaal stikstof (TAN) en voor aanwending van kunstmest als \% van totaalstikstof $(N)$.

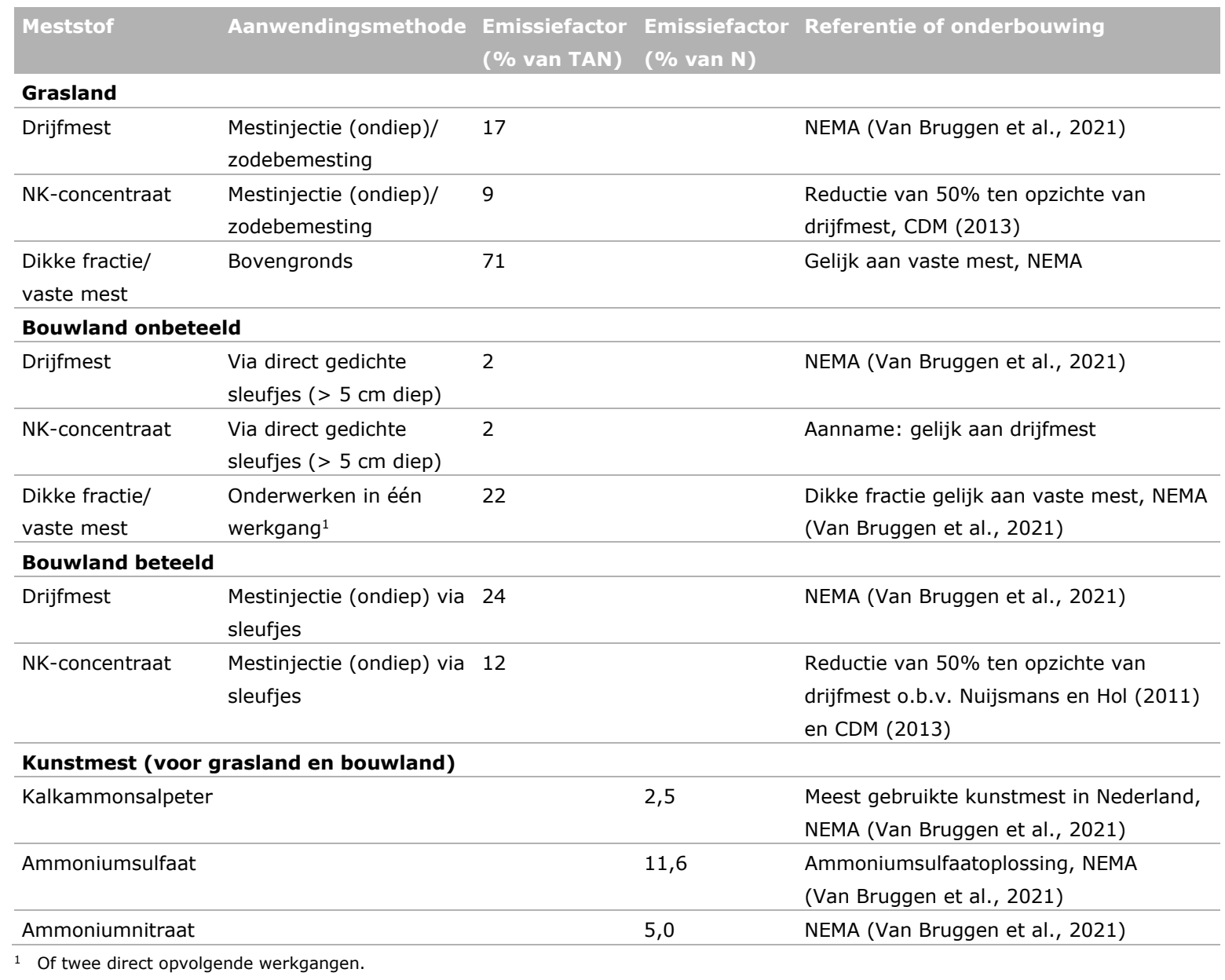

\subsubsection{Lachgasemissies}

Lachgas $\left(\mathrm{N}_{2} \mathrm{O}\right)$ is een zeer sterk broeikasgas, elke $\mathrm{kg}$ heeft een broeikasgaswerking equivalent aan $298 \mathrm{~kg} \mathrm{CO}_{2}$. Lachgas wordt gevormd als bijproduct bij denitrificatie van nitraat tot stikstofgas. Lachgas kan ook ontstaan bij nitrificatie van ammoniak naar nitraat. De emissiefactoren voor lachgas zijn zeer onzeker, omdat het biologische processen betreft waardoor de omzettingssnelheid sterk afhankelijk is van o.a. temperatuur, zuurstofconcentratie en vochtgehalte. Door de beschikbaarheid van zuurstof in opgeslagen dikke fractie zijn lachgasemissies daaruit groter dan uit opgeslagen drijfmest. In de nationale emissieberekeningen (NEMA, Van Bruggen et al., 2021) worden voor drijfmest en dikke fractie respectievelijk emissiefactoren van 0,002 kg N2O/kg N en 0,005 kg N2O/kg N gehanteerd. Daarbij wordt uitgegaan van een opslagduur van zes maanden, waardoor deze waarden niet toepasbaar zijn op mestverwerkers die de dikke fractie voor korte duur opslaan. Omdat de bijdrage van mestopslagen (7\%) aan de totale aan de Nederlandse landbouw toe te schrijven lachgasemissie zeer beperkt is, is deze emissiebron hier niet gekwantificeerd voor de verwerkingsscenario's. De grootste bron van aan de landbouw toe te schrijven lachgasemissies is het vrijkomen van lachgas uit de bodem onder invloed van aanwending van kunstmest en dierlijke mest, waarbij de aanvoer van mineraal stikstof sturend is. Met andere woorden: de hoogte van de stikstofgift en het bodemmanagement zijn meer bepalend voor de lachgasemissie dan de herkomst van de stikstofmeststof.

Vanwege de grote onzekerheden in de emissiefactoren en de beperkte invloed van mestbewerking op de emissiefactoren, zijn lachgasemissies in de hier uitgevoerde berekening van de $\mathrm{CO}_{2}$-voetafdruk niet meegenomen. In het TKI PPS-project 'NL Next Level Mestverwaarding' zijn lachgasemissies wel meegenomen in de emissieberekeningen (Gollenbeek et al., 2021). 


\subsection{Resultaten en discussie}

\subsubsection{Vermeden methaanemissies}

Figuur 7.2 toont de berekende methaanemissies voor (scenario A1) opslag van varkensdrijfmest in een mestkelder gedurende vier tot zes maanden, (scenario A2) één maand opslag van varkensdrijfmest gevolgd door scheiding in NK-concentraat en een stapelbare dikke fractie en (alle scenario's B en C) één maand opslag van drijfmest gevolgd door vergisting. Indien de veehouder mest onder contract afzet naar de verwerker, dan is maandelijkse afvoer de huidige praktijk. Bij opslag van drijfmest gedurende vier tot zes maanden wordt circa $5,6 \mathrm{~m}^{3} \mathrm{CH}_{4}$ gevormd per ton mest $\left(92 \mathrm{~kg} \mathrm{CO}_{2}-\right.$ equivalenten per ton mest). Door de opslagduur in de mestkelder te beperken tot hooguit één maand en de drijfmest daarna te scheiden, daalt de totale methaanemissie met circa $66 \%$. Hiermee wordt scheiding tot een stapelbare dikke fractie en een NK-concentraat of dunne fractie bedoeld, waarvan de laatste twee een drogestofgehalte van ten hoogste $5 \%$ hebben. Indien de scheiding een verpompbare dikke fractie oplevert, is voor de opslag van de scheidingsproducten geen sprake van vermeden methaanemissies t.o.v. de opslag van drijfmest. Vergisting van drijfmest resulteert in een verdere verlaging van de methaanemissies, mits goed operationeel management de emissies van lekverliezen beperkt tot $1,0 \%$ van de methaanproductie. Ook andere studies bevestigen dat het verkorten van de opslagduur van drijfmest in de mestkelder leidt tot vermindering van methaanemissies (De Vries et al., 2011 en 2012a,b; Gollenbeek et al., 2021). Er zijn echter grote onzekerheden in de emissiefactoren voor methaan en meer praktijkmetingen, zoals recent uitgevoerd door Well et al. (2020), zijn nodig om de hier berekende waarden te valideren.

In de berekening van de $\mathrm{CO}_{2}$-voetafdruk voor de verwerkingsscenario's is de vermeden methaanemissie ten opzichte vier tot zes maanden durende opslag van varkensdrijfmest (scenario A1) opgenomen.

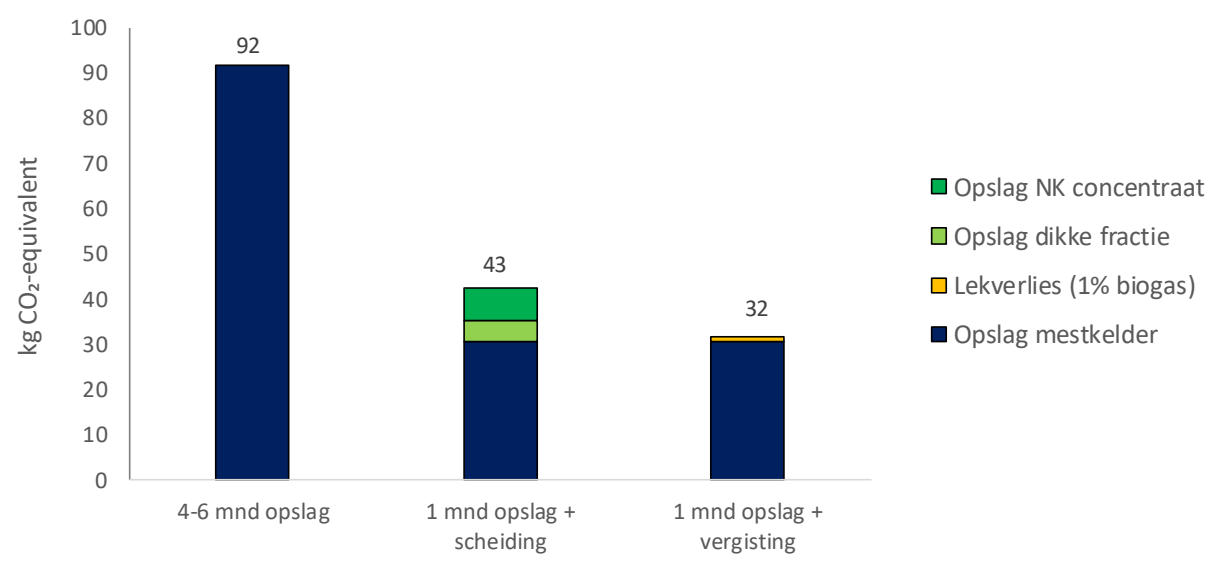

Figuur 7.2 Berekende methaanemissies in $\mathrm{CO}_{2}$-equivalenten per ton verwerkte mest voor (scenario A1) opslag van varkensdrijfmest in een mestkelder gedurende vier tot zes maanden, (scenario A2) één maand opslag van varkensdrijfmest gevolgd door scheiding in NK-concentraat en een stapelbare dikke fractie en (alle scenario's $B$ en $C$ ) één maand opslag van drijfmest gevolgd door vergisting. In de $\mathrm{CO}_{2}$-voetafdruk is voor scenario's $A 2, B$ en $C$ de vermeden methaanemissie ten opzichte van vier tot zes maanden opslag in de mestkelder meegenomen. Gehanteerd is: $1 \mathrm{~kg}^{3} \mathrm{CH}_{4}=$ $1,52 \mathrm{~m}^{3} \mathrm{CH}_{4}=25 \mathrm{~kg} \mathrm{CO}$-equivalenten.

\subsection{2 $\mathrm{CO}_{2}$-voetafdruk}

\subsubsection{Scenario's A1 en A2}

In scenario $A 1$ wordt ongescheiden varkensdrijfmest na hygiënisatie geëxporteerd. Transport van de mest en verbranding van aardgas voor de hygiënisatie resulteren hier in $\mathrm{CO}_{2}$-emissies. $\mathrm{Er}$ is geen sprake van vermeden methaanemissies, omdat de drijfmest tot het bemestingsseizoen wordt 
opgeslagen in de mestkelder van de veehouder. De hoeveelheid stikstof in de drijfmest maal de werkingscoëfficiënt voor drijfmest is meegenomen als vermeden stikstofkunstmest, omdat door aanwending daarvan bespaard wordt op de productie van stikstofkunstmest. Deze aanwending vindt echter buiten Nederland plaats.

Scenario A2 komt overeen met de bedrijfsvoering van Merensteyn en Van Amstel. Varkensdrijfmest wordt maandelijks bij de veehouder opgehaald waarmee methaanemissies worden vermeden. Daarna wordt de mest gescheiden in dikke fractie, $\mathrm{NK}$-concentraat en loosbaar water. De toename in $\mathrm{CO}_{2}-$ emissies voor elektriciteitsverbruik in dit scenario worden ruimschoots gecompenseerd door de lagere $\mathrm{CO}_{2}$-emissies voor transport. Dit vanwege de verkleinde te transporteren volumes en de mogelijkheid om NK-concentraat in de regio af te zetten. De $\mathrm{CO}_{2}$-emissiereductie voor vermeden stikstofkunstmestgebruik is opgesplitst in vermeden gebruik in de regio door benutting van NKconcentraat als RENURE-materiaal en in vermeden gebruik door benutting van stikstof uit de dikke fractie in de buitenlandse landbouw.

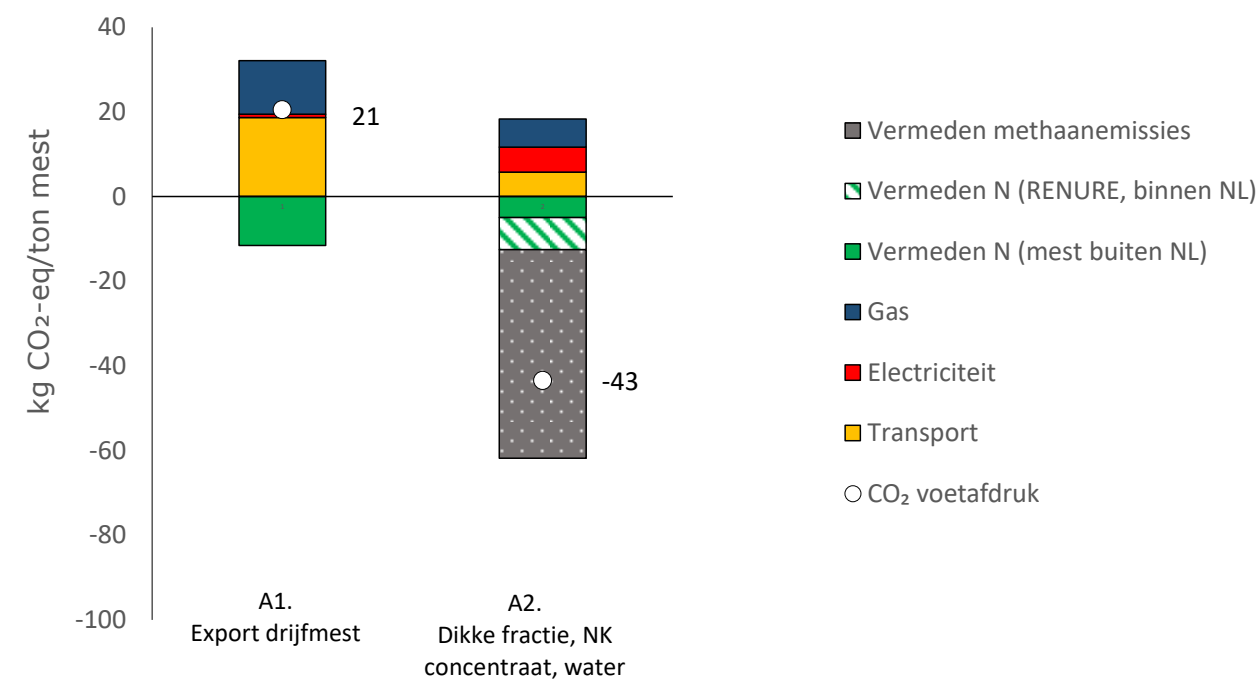

Figuur 7.3 Berekende $\mathrm{CO}_{2}$-voetafdruk per ton verwerkte mest voor (scenario A1) een referentiescenario met export van ongescheiden varkensdrijfmest na hygiënisatie met aardgas en (scenario A2) scheiding van varkensdrijfmest in een dikke fractie (18\%), NK-concentraat (30\%) en loosbaar water (52\%) waarbij het NK-concentraat in de regio wordt benut als kunstmestvervanger. Door maandelijkse afvoer van varkensdrijfmest van de veehouder naar de verwerker in scenario A2 worden methaanemissies vermeden t.o.v. scenario A1, waarin de varkensdrijfmest 4 tot 6 maanden in een mestkelder wordt opgeslagen.

\subsubsection{Scenario's B1 en B2}

In scenario B1 wordt drijfmest co-vergist en het ongescheiden digestaat, na hygiënisatie met restwarmte, geëxporteerd over een afstand van $250 \mathrm{~km}$. Scenario B2 komt overeen met de bedrijfsvoering van Dekker, waarbij het geproduceerde digestaat wordt gescheiden in een dikke en dunne fractie. Door de nabijheid van akkerbouwgebied in de Flevopolder kan de dunne fractie binnen $50 \mathrm{~km}$ worden afgezet. Na hygiënisatie met restwarmte wordt de dikke fractie geëxporteerd over een afstand van $250 \mathrm{~km}$.

Mestscheiding geeft een aanzienlijke verlaging op de $\mathrm{CO}_{2}$-emissie gerelateerd aan mesttransport ten opzichte van export van digestaat en dit voordeel weegt ruimschoots op tegen het hogere energieverbruik voor de scheiding van de mest. In beide scenario's wordt stikstofkunstmest bespaard, omdat stikstof bij bemesting met digestaat en dunne fractie nuttig benut worden. Tevens wordt $\mathrm{CO}_{2}$ vermeden door productie van biogas en omzetting daarvan naar elektriciteit. Biogas is voor circa de helft afkomstig uit mest en voor de helft uit co-producten. Door omzetten van biogas naar elektriciteit wordt tevens restwarmte geproduceerd waardoor het bedrijf geen aardgas nodig heeft voor hygiënisatie van de mest. In termen van broeikasemissies wordt het grootste voordeel gerealiseerd 
door de mest maandelijks bij de veehouder op te halen, waardoor methaanemissies uit mestkelders voorkomen worden.

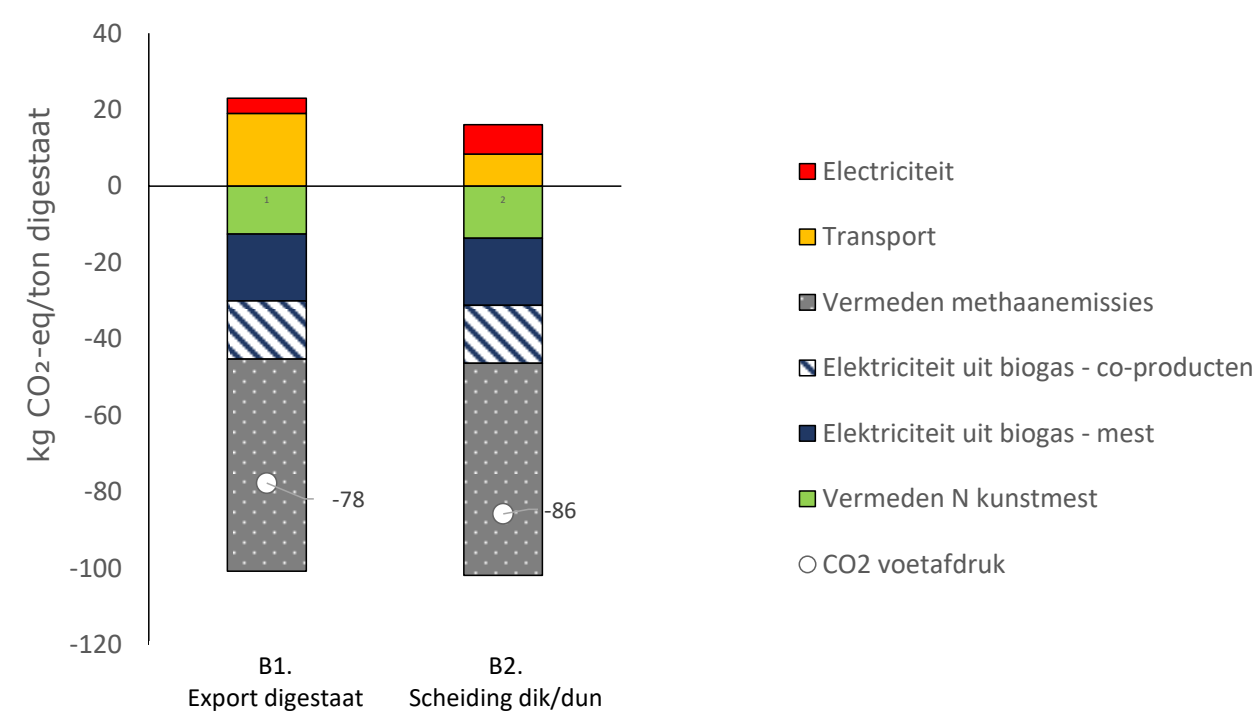

Figuur 7.4 Berekende $\mathrm{CO}_{2}$-voetafdruk per ton verwerkt digestaat voor (scenario B1) een referentiescenario met export van het ongescheiden digestaat en (scenario B2) de bedrijfsvoering van Loonbedrijf Dekker met scheiding van het digestaat in een dunne fractie (80\%), die onder de gebruiksnorm dierlijke mest wordt afgezet en een dikke fractie (20\%) die wordt geëxporteerd. In beide scenario's is er co-vergisting van mest, omzetting van het geproduceerde biogas naar elektriciteit en hygiënisatie met de restwarmte daarvan. De vermeden methaanemissies zijn alleen van toepassing indien de drijfmest maandelijks bij de veehouder wordt opgehaald en direct daarna wordt vergist.

\subsubsection{Scenario's C1, C2 en C3}

In scenario $\mathrm{C} 1$ wordt drijfmest co-vergist en het ongescheiden digestaat geëxporteerd over een afstand van $250 \mathrm{~km}$. In scenario C2 wordt drijfmest co-vergist en gescheiden in een dikke en dunne fractie. De dikke fractie wordt geëxporteerd over een afstand van $250 \mathrm{~km}$ en de dunne fractie wordt afgezet over een afstand van $150 \mathrm{~km}$ binnen de Nederlandse akkerbouw. Scenario C3 komt overeen met de bedrijfsvoering van GZV, waarbij het geproduceerde digestaat wordt gescheiden in een dikke fractie, MF-concentraat, NK-concentraat en loosbaar water. De dikke fractie wordt geëxporteerd, het $\mathrm{NK}$-concentraat in de regio afgezet als kunstmestvervanger en het MF-concentraat afgezet over een afstand van $150 \mathrm{~km}$ binnen de Nederlandse akkerbouw.

Door de vergisting van co-producten en ongeboren mest wordt een hoge biogasproductie behaald. Van de hoeveelheid biogas is circa $77 \%$ toe te schrijven aan de co-producten. Het grootste deel van het biogas wordt afgezet naar een nabijgelegen melk verwerkende fabriek waardoor de energetische waarde ervan volledig wordt benut. Dit resulteert in een hogere vermeden $\mathrm{CO}_{2}$-emissie ten opzichte van biogasomzetting naar elektriciteit. Een beperkt deel van het biogas wordt omgezet in elektriciteit, waarbij de restwarmte voorziet in de warmtevraag van de vergisters en de hygiënisatie.

Door mest te scheiden in een dikke en dunne fractie neemt de $\mathrm{CO}_{2}$-emissie voor transport af, doordat de dunne fractie over een afstand van circa $125 \mathrm{~km}$ kan worden afgezet in de Nederlandse akkerbouw. Hier staat een hoger elektriciteitsverbruik tegenover, waardoor de $\mathrm{CO}_{2}$-voetafdruk van scenario $\mathrm{C} 2$ nagenoeg gelijk is aan die van scenario $\mathrm{C} 1$ waarin het ongescheiden digestaat over een afstand van $250 \mathrm{~km}$ wordt afgezet naar Duitsland.

In scenario C3 neemt het elektriciteitsverbruik verder toe door opwerking van de dunne fractie tot NKconcentraat en loosbaar water en waarbij ook een MF-concentraat ontstaat. Door lozing van water en afzet van NK-concentraat binnen $15 \mathrm{~km}$ van de locatie neemt het transport verder af. Ook in dit 
scenario zijn de $\mathrm{CO}_{2}$-emissies voor extra elektriciteitsverbruik voor verwerking ongeveer gelijk aan de vermeden $\mathrm{CO}_{2}$-emissies door het op kortere afstand kunnen afzetten van de mestproducten. Een aandachtspunt is het grote volume aan MF-concentraat dat over relatief grote afstand afgezet moet worden, omdat dit product onder de gebruiksnorm dierlijke mest valt. GZV werkt aan het verbeteren van de verwerkingsinstallatie om meer loosbaar water en minder MF-concentraat te produceren.

Scenario's $\mathrm{C} 1, \mathrm{C} 2$ en $\mathrm{C} 3$ hebben een nagenoeg gelijke $\mathrm{CO}_{2}$-emissiereductie voor vermeden stikstofkunstmestgebruik. Hierbij is aangenomen dat ook gebruik van digestaat, dunne fractie of dikke fractie resulteert in vermeden stikstofkunstmestgebruik (op basis van de stikstofwerkingscoëfficiënt). Het aandeel stikstofkunstmestgebruik dat vermeden wordt door RENURE-materiaal (kunstmestvervangers) is gearceerd weergegeven. Door co-vergisting heeft het digestaat van GZV een hoog stikstofhalte $(7,4 \mathrm{~g} \mathrm{~N} / \mathrm{kg})$ ten opzichte van varkensdrijfmest $(4,5 \mathrm{~g} \mathrm{~N} / \mathrm{kg})$. Daardoor is de $\mathrm{CO}_{2}$-emissiereductie voor vermeden stikstofkunstmestgebruik groter dan bij mestverwerking zonder toevoeging van co-producten. De co-producten dragen bij aan het vermeden

stikstofkunstmestgebruik; dit is echter alleen duurzaam indien er geen hoogwaardigere toepassing voor de co-producten mogelijk is. Scheiding en opwerking van digestaat resulteren in een verschuiving van $\mathrm{CO}_{2}$-emissies tussen de emissieposten, maar resulteren niet in veranderingen in de totale $\mathrm{CO}_{2}$ voetafdruk.

De vermeden methaanemissies zijn berekend, ervan uitgaande dat iedere veehouder de drijfmest maandelijks laat afvoeren naar de verwerker. In de praktijk is dit alleen het geval voor het aandeel gecontracteerde mest. De in Figuur 7.5 getoonde vermeden methaanemissies zijn het netto voordeel ten opzichte van de opslag van drijfmestmest gedurende vier tot zes maanden in de mestkelder van de veehouder. Aftrek van methaanverliezen uit de vergistingsinstallatie is hierin meegenomen.

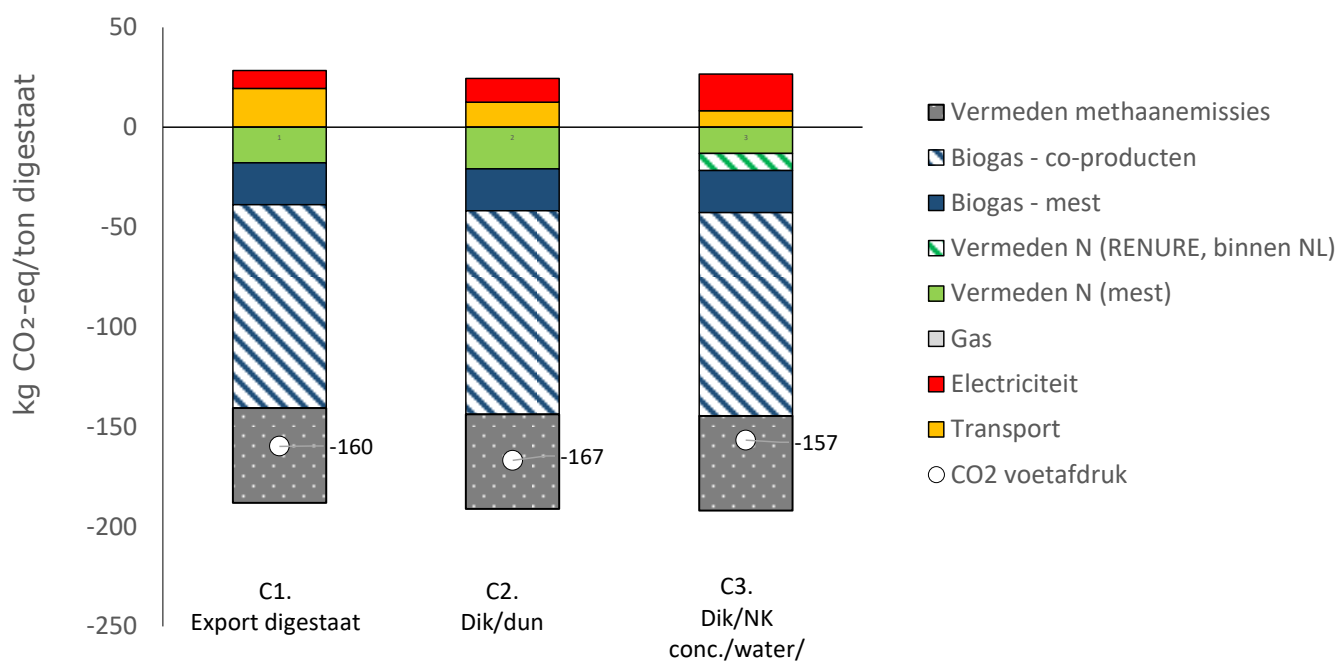

Figuur 7.5 Berekende $\mathrm{CO}_{2}$-voetafdruk per ton verwerkt digestaat voor (scenario C1) een referentiescenario met export van ongescheiden digestaat over een afstand van $250 \mathrm{~km}$ en (scenario C2) scheiding van het digestaat in een dunne fractie (85\%) die onder de gebruiksnorm dierlijke mest wordt afgezet en een dikke fractie (15\%) die wordt geëxporteerd en (scenario C3) de bedrijfsvoering van GZV in 2020 met scheiding van het digestaat in dikke fractie (15\%), micro-filtratieconcentraat (37\%), NK-concentraat (30\%) en loosbaar water (18\%). In alle drie de scenario's is er co-vergisting van mest, omzetting van een deel van het biogas naar elektriciteit en hygiënisatie met de restwarmte daarvan. De vermeden methaanemissies zijn alleen van toepassing indien de drijfmest maandelijks bij de veehouder wordt opgehaald en direct daarna wordt vergist.

\subsubsection{Discussie}

De $\mathrm{CO}_{2}$-voetafdruk is berekend voor scenario's met scheiding van mest of co-vergisting van mest gevolgd door scheiding. Scheiding leidt tot een lagere (scenario's A2 en B2) of gelijke (scenario's C2 
en C3) $\mathrm{CO}_{2}$-voetafdruk ten opzichte van de referentiescenario's waarin drijfmest (scenario A1) of digestaat (scenario's B1 en C1) ongescheiden wordt geëxporteerd. Voor scenario's A, verwerking van varkensdrijfmest zonder co-vergisting, leidt scheiding en opwerking tot NK-concentraat tot een voordeel door minder mesttransport en door vermeden methaanemissies. In scenario's met covergisting van mest zijn twee doelen (opwekking van biogas en verwerking van mest en reststromen) met elkaar verweven. De toegevoegde co-producten en ongeboren mest dragen sterk bij aan de biogasproductie. De aan de varkensdrijfmest, runderdrijfmest en ongeboren mest toe te schrijven energieopbrengst uit biogas is wel voldoende om het elektriciteitsverbruik van de vergistings- en verwerkingsinstallaties te dekken. De energieopbrengst toe te schrijven aan de co-producten kan dus volledig benut worden voor verkoop. Door co-vergisting neemt het drogestofgehalte van het digestaat toe, wat zich bij GZV vertaalt in een hoger elektriciteitsverbruik voor verwerking per ton digestaat. Qua $\mathrm{CO}_{2}$-emissies wordt dit nadeel echter ruimschoots gecompenseerd door de besparing van fossiele energie vanwege biogasproductie uit co-producten.

Hoogwaardige mestverwerking tot NK-concentraat geeft een verschuiving van $\mathrm{CO}_{2}$-emissies ten opzichte van export van ongescheiden drijfmest, waarbij $\mathrm{CO}_{2}$-emissies voor elektriciteitsverbruik van de verwerkingsinstallatie toenemen en die voor mesttransport afnemen. Dit resulteert in een lagere (scenario A2) of gelijke (scenario's C2 en C3) $\mathrm{CO}_{2}$-voetafdruk ten opzichte van langeafstandstransport van ongescheiden drijfmest of digestaat. Op dit moment is er veel aandacht voor het beleidsproces rondom de acceptatie van NK-concentraat als RENURE-materiaal. Daarbij is voor het aspect duurzaamheid aandacht voor het energieverbruik per $\mathrm{kg}$ stikstof in verhouding tot het energieverbruik van de productie van stikstofkunstmest via het Haber-Boschproces. Bij een dergelijke analyse is de keuze voor het referentiescenario van grote invloed.

Het JRC (Huygens et al., 2020) heeft in opdracht van de Europese Commissie tevens $\mathrm{CO}_{2}$-emissies voor de productie van RENURE-materiaal doorgerekend. Het JRC heeft daarvoor de $\mathrm{CO}_{2}$-voetafdruk van scenario's met productie van RENURE-materiaal (NK-concentraat en ammoniumsulfaatoplossing) vergeleken met stikstofverwijdering via biologische behandeling op basis van nitrificatie-denitrificatie. Het JRC concludeert dat verwerking van mest tot een RENURE-materiaal een lagere $\mathrm{CO}_{2}$-voetafdruk heeft dan biologische omzetting van de stikstof in mest tot stikstofgas waarbij een gelijke hoeveelheid stikstof wordt aangekocht in de vorm van kunstmest. Biologische behandeling van mest is gangbaar in o.a. Vlaanderen en Italië waar stikstof sturend is voor het mestoverschot. In Nederland is - tot op heden - het fosfaatgehalte sturend voor het mestoverschot, waardoor scheiding in dikke en dunne fractie de gangbaarste verwerkingsmethode is. Dit leidt tot een andere uitgangssituatie voor de LCA, omdat bij gebruik van dunne fractie (en andere vormen van mest) ook kunstmestgebruik wordt vermeden. Daarnaast vervult mestverwerking méér functies dan alleen het terugwinnen van stikstof, wat betekent dat de $\mathrm{CO}_{2}$-voetafdruk ervan verdeeld moet worden over deze functies. Toch biedt de hier uitgevoerde LCA nuttige inzichten. De productie van stikstofkunstmest via het Haber-Boschproces heeft een $\mathrm{CO}_{2}$-voetafdruk van $3,45 \mathrm{~kg} \mathrm{CO} / \mathrm{kg} \mathrm{N}$. Voor scenario $\mathrm{A} 2$ kan worden afgeleid dat per ton varkensdrijfmest, $2,2 \mathrm{~kg} \mathrm{~N}$ wordt herwonnen als NK-concentraat tegen een elektriciteitsverbruik van $15 \mathrm{kWh}$ /ton mest. Dat komt overeen met $2,7 \mathrm{~kg} \mathrm{CO} / \mathrm{kg} \mathrm{N}$, wat lager is dan de $\mathrm{CO}_{2}$-voetafdruk voor de productie van stikstofkunstmest. Dit betreft het volledige elektriciteitsverbruik van de verwerkingsinstallatie, inclusief zeefbandpers, DAF-installatie, RO-installatie en ionenwisselaar. Het beeld dat mestverwerkingsinstallaties, en met name RO-installaties, een zeer hoog elektriciteitsverbruik hebben, is daarmee onterecht wanneer dit wordt gezien ten opzichte van de productie van stikstofkunstmest.

\subsubsection{Emissies van ammoniak}

Bij aanwending van mest of digestaat treden ammoniakemissies op waarvan de grootte afhankelijk is van de aanwendingstechniek. NK-concentraat is, net als drijfmest, een emissiegevoelige meststof vanwege het hoge gehalte $\mathrm{N}-\mathrm{NH}_{4}$ en de hoge $\mathrm{pH}$. Emissiearme aanwending is daarom noodzakelijk om emissies te beheersen.

Het effect van mestscheiding en gebruik van NK-concentraat als kunstmestvervanger op de totale ammoniakemissie is niet eenduidig. Dit omdat de grootte van de emissie afhangt van de aanwendingsmethode, de toepassing (grasland, onbeteeld of beteeld bouwland) en het 
referentiescenario waar de emissie mee vergeleken wordt. Effecten zijn daarom beschreven aan de hand van de emissiefactoren voor aanwending van NK-concentraten en andere meststoffen (Tabel 7.8). Daarnaast zijn er onzekerheden in de emissiefactoren en is er behoefte aan aanvullende metingen onder praktijkcondities om emissiefactoren voor nieuwe meststoffen vast te stellen.

Aanwending van NK-concentraat als alternatief voor drijfmest resulteert in een lagere ammoniakemissie omdat NK-concentraat - vanwege de lagere viscositeit - sneller in de bodem infiltreert. Bij aanwending van NK-concentraat op grasland als kunstmestvervanger is sprake van grotere ammoniakemissies t.o.v. het gebruik van CAN-kunstmest - veruit de meest gebruikte stikstofkunstmest in Nederland. Bij aanwending van een mengsel van drijfmest en NK-concentraat wordt het effect van de lagere viscositeit van NK-concentraat (deels) tenietgedaan. Daarom wordt verondersteld dat de emissiefactor voor drijfmest dan van toepassing is. Op onbeteeld bouwland kan het NK-concentraat op grotere diepte geïnjecteerd worden waardoor de emissies lager zijn t.o.v. grasland. Op bouwland kan NK-concentraat zodoende kunstmest vervangen zonder dat daarbij de ammoniakemissies stijgen t.o.v. kunstmest. Op beteeld bouwland, waarbij het NK-concentraat minder diep wordt geïnjecteerd, neemt het risico op ammoniakemissies toe waardoor deze toepassing af te raden is, tenzij het NK-concentraat emissiearm wordt toegediend. Ontwikkeling en verbetering van aanwendingstechnieken voor nieuwe meststoffen dragen bij aan verdere verlaging van de aanwendingsemissies.

Aanzuren van NK-concentraat is een mogelijkheid om opslag- en aanwendingsemissies te beheersen; echter, NK-concentraat heeft een groot bufferend vermogen waardoor een forse hoeveelheid zuur toegevoegd moet worden om de $\mathrm{pH}$ voldoende te verlagen. Bij de productie van NK-concentraat wordt immers zwavelzuur gedoseerd voor de RO-installatie, maar dit leidt niet tot een substantiële verlaging van de $\mathrm{pH}$-waarde t.o.v. ongescheiden drijfmest of digestaat. Verhogen van de zuurdosering om ammoniakemissies tegen te gaan is ongewenst indien hiervoor zwavelzuur wordt gebruikt, omdat meststoffen met een hoog zwavelgehalte niet goed zijn in te passen in een bemestingsplan. Een andere denkrichting om ammoniakemissies vanuit herwonnen meststoffen te verminderen, is het verkennen van mogelijkheden voor de productie van nitraatmeststoffen uit dierlijke mest. De door het verwerkingsproces 'GreenSwitch' geproduceerde meststof ${ }^{21}$, gemaakt door strippen van ammoniak gevolgd door omzetting van het gestripte ammoniak naar nitraat via beluchting, is hier een voorbeeld van. Ook het opwerken van mest tot ammoniakwater voor de industrie - zoals het verwerkingsproces van Twence - draagt bij aan vermindering van ammoniakemissies uit de landbouw.

Bij mestscheiding ontstaat tevens een dikke fractie met daarin circa $50 \%$ van de stikstof en $30 \%$ van de $\mathrm{N}-\mathrm{NH}_{4}$ uit de ingaande mest. Voor dikke fracties is emissiearme aanwending niet mogelijk waardoor bij aanwending op grasland $70 \%$ van de $\mathrm{N}-\mathrm{NH}_{4}$ emitteert en op bouwland - bij onderwerken in één werkgang - 22\% emitteert. Op dit moment worden dikke fracties van varkensdrijfmest afgezet naar het buitenland, waardoor de aanwendingsemissies niet meetellen voor de nationale balans. Indien meer mest wordt verwerkt dan nodig is om het overschot aan fosfaat buiten de landbouw af te zetten (verplichte mestverwerking via een tweesporenbeleid), zal er een markt voor dikke fracties in Nederland ontstaan. Daardoor kunnen ammoniakemissies binnen de Nederlandse landbouw toenemen. Met name op grasland moet het gebruik van dikke fracties ontraden worden vanwege de hoge aanwendingsemissies t.o.v. drijfmest. Dit geldt niet voor gecomposteerde of gedroogde dikke fracties, omdat de ammoniak dan al tijdens het verwerkingsproces vervluchtigt en daarna afgevangen is in luchtwassers. In dat geval ontstaat, als spuiwater van de luchtwasser, een ammoniumsulfaatoplossing waarvan aanwending kan leiden tot ammoniakemissies.

\footnotetext{
${ }^{21}$ https://www.vaniperen.com/story/greenswitch/
} 


\subsection{Conclusies}

- De $\mathrm{CO}_{2}$-emissie voor energieverbruik van mestverwerkingsinstallaties is kleiner dan, of maximaal even groot als, de $\mathrm{CO}_{2}$-emissiervermindering voor transport door volumereductie en afzet van eindproducten in de regio. Dit geldt zowel voor scheiding in een dikke en dunne fractie als voor hoogwaardigere verwerking tot NK-concentraat. Mestscheiding is daarmee een duurzaam alternatief ten opzichte van langeafstandswegtransporten van ongescheiden drijfmest.

- Qua broeikasgasemissies wordt veruit het grootste voordeel behaald door drijfmest maandelijks af te voeren vanuit de mestkelder van de veehouder naar de verwerker, waarna de mest ofwel wordt vergist, ofwel hoogwaardige scheiding ondergaat. Door de korte opslagduur in de mestkelder verminderen de methaanemissies bij de veehouder. Dit kan gerealiseerd worden door drijfmest onder contract te laten verwerken bij mestverwerkers (wat deels ook al gebeurt).

- NK-concentraat mag - onder een tijdelijke vrijstelling - gebruikt worden (boven op de gebruiksnorm voor dierlijke mest) als kunstmestvervanger. De $\mathrm{CO}_{2}$-voetafdruk voor de productie van NKconcentraat uit varkensdrijfmest is lager dan die voor de productie van dezelfde hoeveelheid stikstof via het Haber-Boschproces. Stikstof uit dierlijke mest kan daarnaast ook in andere vormen nuttig gebruikt worden in de landbouw (dunne fractie, digestaat) en daarmee kunstmestverbruik verminderen. Wat de duurzaamste oplossing is, hangt af van het type mestproducten waar behoefte aan is in de regio van de mestverwerker.

- Het effect van mestscheiding en gebruik van NK-concentraat als kunstmestvervanger op ammoniakemissies is onduidelijk, mede omdat de aanwendingsemissies voor NK-concentraat afhangen van de toepassing op grasland versus bouwland. Aanwendingsemissies voor bemesting met NK-concentraat zijn lager dan voor bemesting met drijfmest en gelijk aan of hoger ten opzichte van bemesting met kunstmest.

- Aanbevolen wordt om meer aandacht te besteden aan het vaststellen van methaanemissiefactoren uit mestkelders en methaanemissies uit vergistingsinstallaties. Er is nu veel onzekerheid over de hoogte van deze factoren, terwijl deze wel van grote impact zijn op de $\mathrm{CO}_{2}$-voetafdruk van mest- en digestaatverwerkers. 


\section{Stikstof- en fosfaatbalans Nederlandse landbouw}

\subsection{Trends in nutriëntenbalansen}

De Nederlandse mestmarkt is continu in beweging als gevolg van veranderingen in o.a. dieraantallen, hoogte van fosfaatgebruiksnormen en wet- en regelgeving rondom verplichte verwerking van mest. De mestprijs daalde in 2020 en dit leidde ook tot een lagere aanvoer van mest naar mestverwerkers. Het is daarom van belang om inzicht te hebben in de nutriëntenbalansen voor fosfaat en stikstof en ontwikkelingen daarin, zodat vanuit overheden gestuurd kan worden op een mestverwerkingscapaciteit die past bij de huidige en toekomstige behoefte. Dit hoofdstuk gaat in op de trends in fosfaat- en stikstofbalansen in de periode 2015-2019. Hiervoor zijn data gebruikt van het INITATOR-model (Kros et al., 2018). Het model simuleert de verdeling van mest, rekening houdend met de aanvoer van dierlijke mest (van eigen bedrijf of bedrijfsvreemd), overige organische meststoffen en kunstmest en de wettelijke gebruiksnormen. De mestverdelingsmodule van het model rekent op bedrijfsniveau en houdt rekening met de fosfaattoestand van de bodem en de gebruiksnormen voor fosfaat en stikstof zowel in de vorm van organische bemestingsproducten als minerale kunstmest. Het model berekent de ruimtelijke verdeling van mesttoediening en daarmee veroorzaakte ammoniakemissies. Het model wordt o.a. gebruikt ten behoeve van wettelijke onderzoekstaken naar het in kaart brengen van mestverdeling, uitspoeling van nutriënten en ammoniakemissies. In dit rapport is de ruimtelijke verdeling van mest niet gepresenteerd, maar wel de hieruit volgende totale plaatsingsruimte voor dierlijke mest.

Figuur 8.1 toont de stikstof- en fosfaatuitscheiding door varkens en runderen in Nederland in de periode 2015-2019. De fosfaatuitscheiding door runderen daalde $15 \%$, met $16 \mathrm{mln}$. $\mathrm{kg} \mathrm{P}_{2} \mathrm{O}_{5}$, terwijl de stikstofuitscheiding gelijk bleef. Hierdoor steeg de $\mathrm{N} / \mathrm{P}_{2} \mathrm{O}_{5}$-ratio van runderdrijfmest. Deze afname wordt deels verklaard door een dalend fosforgehalte in ruwvoer (specifiek graskuil), wat mogelijk duidt op een afname in de fosfaatbeschikbaarheid van grasland. Voor varkens is zowel de fosfaat- als stikstofuitscheiding gedaald, respectievelijk 3,3 mln. $\mathrm{kg} \mathrm{P}_{2} \mathrm{O}_{5}(8,2 \%)$ en $3,4 \mathrm{mln}$. $\mathrm{kg} \mathrm{N}(4,5 \%)$, door opkoopmaatregelen die geleid hebben tot krimp van de dieraantallen.

Uitscheiding runderen

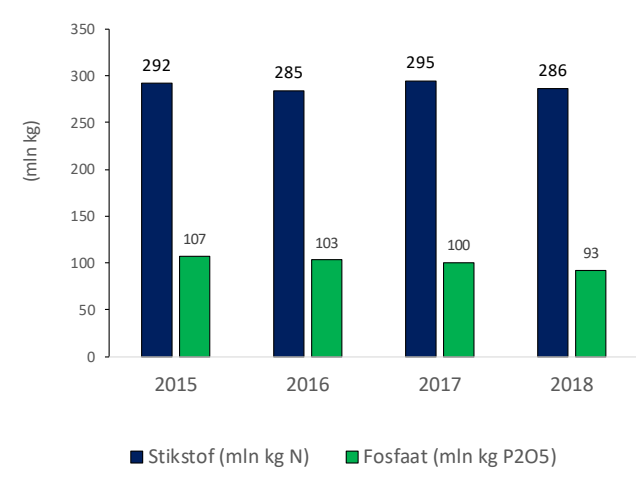

Uitscheiding varkens
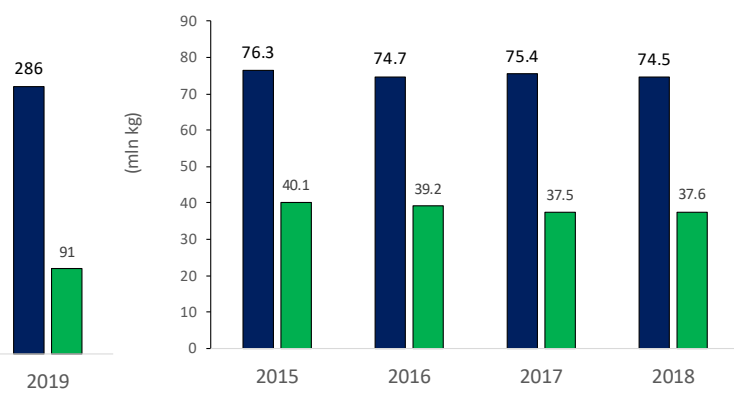

2018

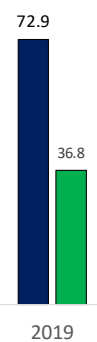

- Stikstof (mln kg N) पFosfaat (mln kg P2O5)

Figuur 8.1 Verloop in de uitscheiding van stikstof $(N)$ en fosfaat $\left(\mathrm{P}_{2} \mathrm{O}_{5}\right)$ door varkens en runderen in Nederland als jaartotaal in de periode 2015-2019. ${ }^{22}$ Stikstof in opgeslagen mest en weidemest na aftrek stalemissies, data CBS. ${ }^{23}$

\footnotetext{
22 Uitscheiding runderen inclusief graasdieren (schapen, geiten, paarden, ezels). De uitscheiding wijkt daardoor af van CBS waar graasdieren, niet-zijnde runderen, in de categorie 'overige' vallen.

${ }^{23}$ Weidemest: mest die bij beweiding direct door grazende dieren op het grasland wordt uitgescheiden.
} 
Figuur 8.2 toont de Nederlandse plaatsingsruimte voor fosfaat en stikstof uit dierlijke mest. De totale plaatsingsruimte voor fosfaat, aangeduid met P-lim, is beschikbaar voor plaatsing van dierlijke mest, overige organische meststoffen en fosfaatkunstmest. De plaatsingsruimte P-lim is berekend als het areaal aan landbouwgrond maal de fosfaatgebruiksnorm, zonder rekening te houden met beperkingen door de gebruiksnorm dierlijke mest (stikstof). De fosfaatplaatsingsruimte NP-lim is de plaatsingsruimte beschikbaar voor dierlijke mest, waarbij rekening wordt gehouden met de verhouding $\mathrm{N} / \mathrm{P}_{2} \mathrm{O}_{5}$ in de mest en de gebruiksnormen voor zowel fosfaat als stikstof in de vorm van dierlijke mest. Evenzo kan de totale stikstofgebruiksruimte op basis van de stikstofnorm voor dierlijke mest ( $\mathrm{N}$-lim) alsook die waarbij ook rekening wordt gehouden met beperkingen door de fosfaatgebruiksnormen en de $\mathrm{N} / \mathrm{P}_{2} \mathrm{O}_{5}$ ratio in de mest (NP-lim).

De totale P-plaatsingsruimte (P-lim) is sinds 2015 constant gebleven, omdat zowel areaal als de fosfaatgebruiksnormen nagenoeg gelijk zijn gebleven. Van de totale P-plaatsingsruimte (132 $\mathrm{mln}$. kg $\mathrm{P}_{2} \mathrm{O}_{5}$ in 2019) werd jaarlijks circa $6 \mathrm{mln}$. $\mathrm{kg}$ ingevuld met overige organische meststoffen waaronder compost en digestaat, niet-zijnde dierlijke mest. Terwijl de totale P-plaatsingsruimte constant bleef, daalde de P-plaatsingsruimte voor dierlijke mest (NP-lim) van 118 tot $108 \mathrm{mln}$. kg $\mathrm{P}_{2} \mathrm{O}_{5}$. Dit is het gevolg van de toenemende verhouding $\mathrm{N} / \mathrm{P}_{2} \mathrm{O}_{5}$ in rundermest, waardoor stikstof de beperkende factor werd bij aanwending van rundermest.

De verhouding $\mathrm{N} / \mathrm{P}_{2} \mathrm{O}_{5}$ in rundermest steeg van $2,7 \mathrm{~kg} / \mathrm{kg}$ naar $3,2 \mathrm{~kg} / \mathrm{kg}$ in de periode 2015-2019 door verlaging van de fosforgehalten in veevoer. Hierdoor wordt de fosfaatgebruiksruimte op rundveebedrijven niet volledig benut. Bij een verhouding $\mathrm{N} / \mathrm{P}_{2} \mathrm{O}_{5}$ van 3,2 en een gebruiksnorm dierlijke mest van $230 \mathrm{~kg} \mathrm{~N} / \mathrm{ha}$ (derogatie op zandgrond) bedraagt de fosfaatgift $71 \mathrm{~kg} \mathrm{P}_{2} \mathrm{O}_{5} /$ ha en deze is lager dan de fosfaatgebruiksnorm. De fosfaatgebruiksnorm ligt namelijk, afhankelijk van de fosfaattoestand van de bodem, tussen de 75 en $105 \mathrm{~kg} \mathrm{P}_{2} \mathrm{O}_{5} /$ ha. Door de stijgende verhouding $\mathrm{N} / \mathrm{P}_{2} \mathrm{O}_{5}$ in rundermest is stikstof in meer gevallen de factor die aanwending beperkt, waardoor de onderbenutting van de fosfaatgebruiksruimte is toegenomen. De voermaatregelen ter verlaging van de fosfaatuitscheiding van rundvee hebben daarmee slechts een beperkt effect op de hoeveelheid fosfaat die buiten het eigen bedrijf wordt afgezet. In 2020 (voorlopige cijfers CBS) is de verhouding $\mathrm{N} / \mathrm{P}_{2} \mathrm{O}_{5}$ in rundermest verder gestegen, en daarmee kan de onderbenutting van de fosfaatgebruiksruimte ook verder toenemen.

Plaatsingsruimte fosfaat $\left(\mathrm{mln} \mathrm{kg} \mathrm{P}_{2} \mathrm{O}_{5}\right)$

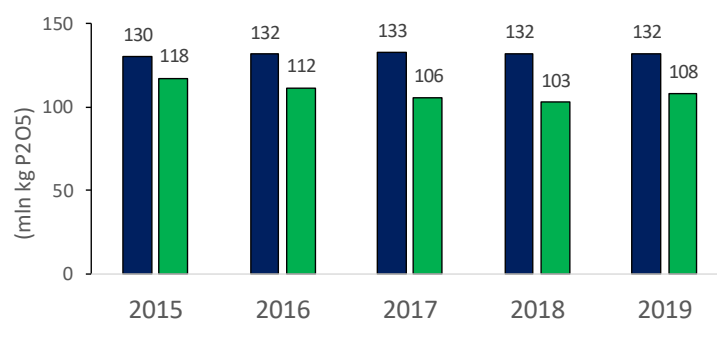

口 Plaatsingsruimte (P-lim) $\square$ Plaatsingsruitme (NP-lim)
Plaatsingsruimte stikstof ( $\mathrm{mln} \mathrm{kg} \mathrm{N})$

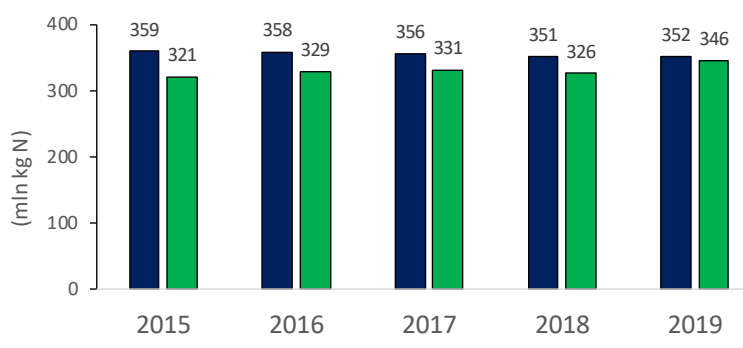

口Plaatsingsruimte (N-lim) $\quad$ P Plaatsingsruitme (NP-lim)

Figuur 8.2 Nederlandse plaatsingsruimte voor fosfaat (gebruiksnorm fosfaat) en stikstof (gebruiksnorm dierlijke mest) per jaar in de periode 2015-2019, berekend met het INITIATOR-model. P-lim: areaal maal fosfaatgebruiksnorm. ${ }^{24} \mathrm{~N}$-lim: areaal maal stikstofgebruiksnorm. NP-lim: plaatsingsruimte berekend o.b.v. de verhouding $\mathrm{N} \mathrm{P}_{2} \mathrm{O}_{5}$ van de beschikbare mest op bedrijfsniveau.

\footnotetext{
${ }^{24}$ Fosfaatgebruiksruimte P-lim: totale gebruiksruimte voor fosfaat uit dierlijke mest, overige organische meststoffen en fosfaatkunstmest. Stikstofgebruiksruimte $(\mathrm{N}-\mathrm{lim})$ : totale gebruiksruimte voor stikstof uit dierlijke mest (gebruiksnorm dierlijke mest). Overige organische meststoffen tellen niet mee voor de gebruiksnorm dierlijke mest. Fosfaat- en stikstofgebruiksruimte NP-lim: gebruiksruimte voor fosfaat en stikstof uit dierlijke mest rekening houdend met de verhouding $\mathrm{N} / \mathrm{P}_{2} \mathrm{O}_{5}$ in de mest.
} 
De Nederlandse fosfaat- en stikstofbalans voor dierlijke mest voor het jaar 2019 is opgenomen in Tabel 8.1. De fosfaatuitscheiding van de veestapel inclusief mestimport bedroeg $157 \mathrm{mln}$. $\mathrm{kg} \mathrm{P}_{2} \mathrm{O}_{5}$ en hiervan werd $47 \mathrm{mln}$. $\mathrm{kg} \mathrm{P}_{2} \mathrm{O}_{5}$ buiten de Nederlandse landbouw afgezet. ${ }^{25}$ De resterende $111 \mathrm{mln}$. kg $\mathrm{P}_{2} \mathrm{O}_{5}$ werd in de landbouw geplaatst. Op basis van de totale fosfaatgebruiksruimte kan, na aftrek van $6 \mathrm{mln}$. kg $\mathrm{P}_{2} \mathrm{O}_{5}$ aan overige organische meststoffen, $124 \mathrm{mln}$. kg $\mathrm{P}_{2} \mathrm{O}_{5}$ geplaatst worden, wat zou betekenen dat het fosfaatoverschot $31 \mathrm{mln}$. $\mathrm{kg} \mathrm{P}_{2} \mathrm{O}_{5}$ bedraagt. Wanneer echter ook rekening wordt gehouden met het stikstofgehalte van de mest, is de fosfaatgebruiksruimte beperkt tot $108 \mathrm{mln}$. $\mathrm{kg}$ $\mathrm{P}_{2} \mathrm{O}_{5}$. Om alle mest te plaatsen binnen de fosfaatgebruiksnorm en de gebruiksnorm dierlijke mest, moet circa $49 \mathrm{mln}$. kg $\mathrm{P}_{2} \mathrm{O}_{5}$ en $83 \mathrm{mln}$. kg N buiten de landbouw afgezet worden. Dit is ongeveer gelijk aan de in 2019 gerealiseerde afzet buiten de landbouw (47 mln. kg $\mathrm{P}_{2} \mathrm{O}_{5}$ en $81 \mathrm{mln}$. kg N). De verschillen tussen het berekende overschot en de gerealiseerde export zouden kunnen wijzen op overbemesting, maar het verschil is dermate klein dat dit binnen de foutmarge van de berekeningen valt.

Uitgaande van een benodigde fosfaatexport van $49 \mathrm{mln}$. $\mathrm{kg} \mathrm{P}_{2} \mathrm{O}_{5}$, kan de verdeling over mestsoorten gemaakt worden. Hierbij is ervan uitgegaan dat kippenmest nagenoeg volledig wordt verwerkt of geëxporteerd $\left(26 \mathrm{mln}\right.$. $\mathrm{kg} \mathrm{P}_{2} \mathrm{O}_{5}$ ). Voor rundermest is een overschot van $7 \mathrm{mln}$. $\mathrm{kg}_{2} \mathrm{O}_{5}$ berekend waarvan een deel naar hobby- en natuurterreinen wordt afgezet ( $4 \mathrm{mln}$. kg $\mathrm{P}_{2} \mathrm{O}_{5}, \mathrm{CBS}, 2019$ ). Voor varkensmest zou dan circa $16 \mathrm{mln}$. $\mathrm{kg} \mathrm{P}_{2} \mathrm{O}_{5}$ buiten de landbouw geplaatst moeten worden. Hiervan wordt circa $1 \mathrm{mln}$. kg $\mathrm{P}_{2} \mathrm{O}_{5}$ afgezet naar hobbybedrijven (CBS, 2019) en zal $15 \mathrm{mln}$. kg $\mathrm{P}_{2} \mathrm{O}_{5}$ via export/verwerking buiten de landbouw geplaatst moeten worden.

In termen van stikstof is het overschot aanzienlijk kleiner. Voor varkensmest werd circa $70 \%$ van de uitgescheiden stikstof benut binnen de Nederlandse landbouw. Er wordt, t.o.v. de uitscheiding, meer stikstof dan fosfaat uit varkensmest binnen Nederland toegepast, wat betekent dat een deel wordt toegepast in de vorm van dunne fractie, wat een hogere verhouding $\mathrm{N} / \mathrm{P}_{2} \mathrm{O}_{5}$ heeft dan ongescheiden mest. Boven op het gebruik als dierlijke mest wordt volgens gegevens van het NCM circa 2,5 mln. kg $\mathrm{N}$ als mineralenconcentraat toegepast onder de pilot 'Mineralenconcentraten' (NCM, 2021).

De verwachting is dat de dalende trend in de mestproductie verder zal doorzetten, o.a. door opkoop van veehouderijen in het kader van de stikstofmaatregelen. Mestverwerking wordt nu gestuurd door het fosfaatoverschot. Veehouderijen zijn verplicht een deel van het bedrijfsoverschot aan fosfaat te laten verwerken of exporten, al dan niet via de aankoop van VVO's (paragraaf 6.2.7). Bij een dalend fosfaatoverschot betekent dit een dalend aanbod van mest naar mestverwerkingsinstallaties, tenzij in de nabije toekomst condities worden opgelegd m.b.t. de verplichte mestverwerking zoals voorgesteld in het kader van het tweesporenbeleid, waarbij alle mest van niet-grondgebonden bedrijven zou moeten worden verwerkt.

Bovenstaande inschatting van de nodige verwerkingscapaciteit voor varkensmest wijkt aanzienlijk af van recente berekeningen van Koeijer et al. (2020), waarin voor 2020 een overschot van $10 \mathrm{mln}$. kg $\mathrm{P}_{2} \mathrm{O}_{5}$ uit varkens- en rundermest wordt berekend. Verschillen ontstaan onder andere doordat zij uitgaan van een hogere P-plaatsingsruimte van $117 \mathrm{mln}$. $\mathrm{kg} \mathrm{P}_{2} \mathrm{O}_{5}$ voor dierlijke mest. Dit terwijl in de hier uitgevoerde studie is gerekend met een plaatsingsruimte van $108 \mathrm{mln}$. kg $\mathrm{P}_{2} \mathrm{O}_{5}$ uitgaande van limitatie door zowel de fosfaatgebruiksnorm als de stikstofgebruiksnorm voor dierlijke mest en er rekening is gehouden met de ontwikkeling van de verhouding $\mathrm{N} / \mathrm{P}_{2} \mathrm{O}_{5}$ in dierlijke mest.

Het Nederlands Centrum voor Mestverwaarding (NCM) publiceert jaarlijks een overzicht van de fosfaat- en stikstofbalans van de Nederlandse landbouw. Het NCM berekende voor het jaar 2019 een totaal fosfaatoverschot van $38 \mathrm{mln}$. $\mathrm{kg} \mathrm{P}_{2} \mathrm{O}_{5}$ (export, verwerking en afzet buiten landbouw), hetgeen lager is dan het hier berekende overschot. Dit verschil ontstaat deels omdat het NCM aanneemt dat de fosfaatgebruiksruimte volledig wordt benut zonder rekening te houden met beperkingen door het stikstofgehalte en de gebruiksnorm dierlijke mest.

De hier gepresenteerde cijfers op basis van berekeningen met het INITIATOR-model kunnen afwijken van data zoals gepresenteerd door het CBS. Deze verschillen kunnen deels verklaard worden door

\footnotetext{
${ }^{25}$ Afzet buiten de landbouw: export, verwerking en afzet naar hobby- of natuurterreinen.
} 
import en uitscheiding van mest van overige dieren aan verschillende categorieën toe te kennen. CBS kent een aparte categorie voor overige mest en het INITIATOR-model voegt overige mest samen met rundermest (voor graasdieren) of kippenmest (voor niet-graasdieren). Data voor mestexport verschillen, omdat het CBS de mestexport saldeert voor de mestimport. Daarnaast kunnen er kleine verschillen zijn in dieraantallen, excretiefactoren en rekenwijzen tussen beide databestanden. Deze verschillen zijn in de regel relatief klein ten opzichte van de betreffende stroom. Echter, het berekende overschot aan fosfaat en stikstof is het sluitstuk van de balans van een groot aantal complexe berekeningen en kent daarmee een grote onzekerheid door foutenvoortplanting. Met andere woorden: een relatief kleine fout in bijvoorbeeld de berekende uitscheiding van fosfaat resulteert in een relatief grote fout in het berekende overschot aan fosfaat en stikstof.

Tabel 8.1 Nederlandse fosfaat- en stikstofbalans voor dierlijke mest voor het jaar 2019. Data op basis van het INITIATOR-model. ${ }^{1}$

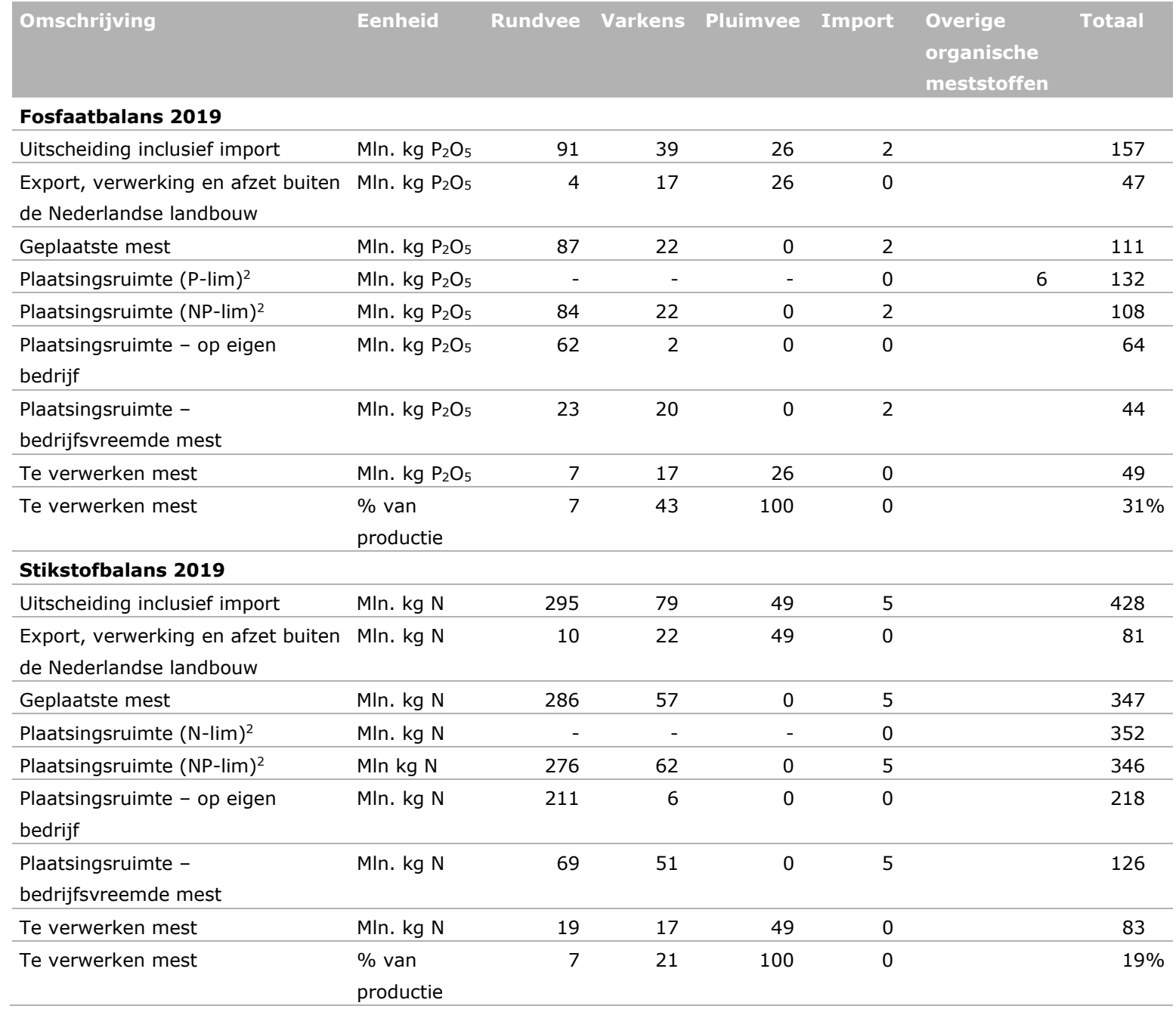

1 Vanwege relatief grote verschillen in de waarden voor fosfaat- en stikstofuitscheiding voor varkens tussen het CBS en het INITIATOR-model is voor de getoonde uitscheiding het gemiddelde van beide bronnen genomen. Bij gebruik van de INITIATOR-waarden zou het fosfaat- en stikstofoverschot voor varkensmest respectievelijk $2 \mathrm{mln}$. kg en $10 \mathrm{mln}$. kg groter zijn dan de hier getoonde waarden.

2 P-lim: areaal maal fosfaatgebruiksnorm. N-lim: areaal maal stikstofgebruiksnorm. NP-lim: plaatsingsruimte berekend o.b.v. de verhouding $\mathrm{N} / \mathrm{P}_{2} \mathrm{O}_{5}$ van de beschikbare mest op bedrijfsniveau.

\subsection{Stikstofbenutting bij gebruik RENURE-materialen}

In het kader van de transitie naar kringlooplandbouw wordt gestreefd naar een betere benutting van de beschikbare dierlijke mest om het gebruik van stikstofkunstmest te verminderen. Er loopt een traject om het gebruik van NK-concentraten uit dierlijke mest boven op de gebruiksnorm dierlijke mest toe te staan indien het bemestingsproduct voldoet aan criteria voor RENURE-materialen (zie 
paragraaf 5.2.2). In dit kader is een inschatting gemaakt van de gebruiksvermindering van stikstofkunstmest door verwerken van varkensmest tot RENURE-materiaal, ervan uitgaande dat $50 \%$ of $100 \%$ van de varkensmest wordt verwerkt tot NK-concentraat en dikke fractie. De totale benutting in termen van werkzame stikstof uit varkensmest is vergeleken met de uitgangssituatie in 2019.

De drie scenario's zijn als volgt omschreven:

1. Referentie: situatie 2019. Verdeling van de varkensmest (drijfmest en dunne fractie) over de beschikbare plaatsingsruime voor varkensmest conform de gerealiseerde aanwending en export. Export van varkensmest vindt plaats in de vorm van dikke fractie en drijfmest. De verhouding drijfmest versus dunne fractie is gefit, zodat de verhouding $\mathrm{N} / \mathrm{P}_{2} \mathrm{O}_{5}$ in de resterende mest gelijk is aan de verhouding $\mathrm{N} / \mathrm{P}_{2} \mathrm{O}_{5}$ van de mestexport/verwerking in 2019 (1,30 kg/kg, INITIATOR). Daarmee benadert de berekende mate van mestscheiding de werkelijkheid.

2. Verwerking van $\mathbf{5 0} \%$ van de varkensmest tot $\mathbf{N K}$-concentraat. Aangenomen wordt dat $50 \%$ van de varkensmest (ongeveer het overschot) wordt verwerkt tot NK-concentraat en toegepast wordt als kunstmestvervanger. Daarnaast worden varkensdrijfmest en een kleine hoeveelheid dikke fractie toegepast, waarbij de fosfaatgebruiksruimte voor varkensmest wordt opgevuld gelijk aan scenario 1.

3. Verwerking van $\mathbf{1 0 0} \%$ van de varkensmest tot $\mathbf{N K}$-concentraat. Alle geproduceerde NKconcentraat wordt toegepast als kunstmestvervanger. Daarnaast wordt de fosfaatgebruiksruimte opgevuld met dikke fractie.

De besparing op stikstofkunstmest is berekend als het verschil in werkzame stikstof bij benutting van de mest(producten) ten opzichte van de referentie (situatie 2019), waarbij de volgende uitgangspunten zijn gebruikt:

- De fosfaatuitscheiding van varkens bedraagt $37 \mathrm{mln}$. kg $\mathrm{P}_{2} \mathrm{O}_{5}$ en $73 \mathrm{mln}$. kg N (CBS, jaar 2019).

- De plaatsingsruimte voor varkensmest bedraagt $22 \mathrm{mln}$. kg $\mathrm{P}_{2} \mathrm{O}_{5}$ en $62 \mathrm{mln}$. kg N (INITIATOR, jaar 2019).

- Bij scheiding van varkensmest in een dikke en een dunne fractie gaat $85 \%$ van het fosfaat en $45 \%$ van de stikstof naar de dikke fractie (Tabel 8.2).

- Bij scheiding van varkensmest in een dikke fractie en NK-concentraat gaat $95 \%$ van het fosfaat en $50 \%$ van de stikstof naar de dikke fractie (Tabel 8.2).

- De werkzame stikstof is berekend conform de wettelijke werkingscoëfficiënt voor dierlijke mest. ${ }^{26}$ Deze bedraagt $100 \%$ voor NK-concentraat, $55 \%$ voor dikke fractie, $80 \%$ voor dunne fractie, $60 \%$ voor drijfmest op klei/veen en $80 \%$ voor drijfmest op zand/löss. Voor drijfmest is gerekend met een gemiddelde werkingscoëfficiënt van $70 \%$, ervan uitgaande dat de drijfmest evenredig wordt toegepast op zand- en kleigronden.

Tabel 8.2 Gehanteerde massabalans (als \% van ingaand) voor berekening van de stikstofbenutting voor de scheiding van varkensdrijfmest in dikke en dunne fractie of in dikke fractie en NK-concentraat en de verhouding $\mathrm{N} / \mathrm{P}_{2} \mathrm{O}_{5}$ in de producten van die scheidingen.

\begin{tabular}{|c|c|c|c|c|c|}
\hline In- en uitgaande stromen & Totale massa & $\mathbf{N}$ & $\mathrm{N}-\mathrm{NH}_{4}$ & $\mathrm{P}_{2} \mathrm{O}_{5}$ & Verhouding $\mathrm{N} / \mathrm{P}_{2} \mathrm{O}_{5}$ \\
\hline Drijfmest (ingaand) & 100 & 100 & 100 & 100 & 2,0 \\
\hline \multicolumn{6}{|c|}{ Scheiding in dikke en dunne fractie } \\
\hline Dunne fractie & 80 & 55 & 71 & 15 & 7,3 \\
\hline \multicolumn{6}{|c|}{ Scheiding in dikke fractie, NK-concentraat en loosbaar water } \\
\hline NK-concentraat & 40 & 50 & 71 & 5 & 19,8 \\
\hline Loosbaar water & 40 & 0 & 0 & 0 & \\
\hline
\end{tabular}

De uitkomsten van de doorrekening van de drie scenario's zijn opgenomen in Tabel 8.3. In de referentie (situatie 2019) werd $22 \mathrm{mln}$. $\mathrm{kg} \mathrm{P}_{2} \mathrm{O}_{5}$ uit varkensmest toegepast. Naar schatting werd

\footnotetext{
${ }^{26}$ https://www.rvo.nl/sites/default/files/2019/01/Tabel-3-Werkingscoefficient-2019-2021.pdf
} 
$38 \mathrm{mln}$. kg N als drijfmest en $13 \mathrm{mln}$. kg N als dunne fractie toegepast. In dit scenario wordt $51 \mathrm{mln}$. $\mathrm{kg} \mathrm{N}$ uit varkensmest benut binnen Nederland met een werkzaamheid van $37 \mathrm{mln}$. kg N.

Tabel 8.3 Benutting van mest(producten) uit varkensmest voor de referentie (situatie 2019) en bij verwerking van $50 \%$ of $100 \%$ van de varkensdrijfmest tot NK-concentraat. Aannames: zie tekst.

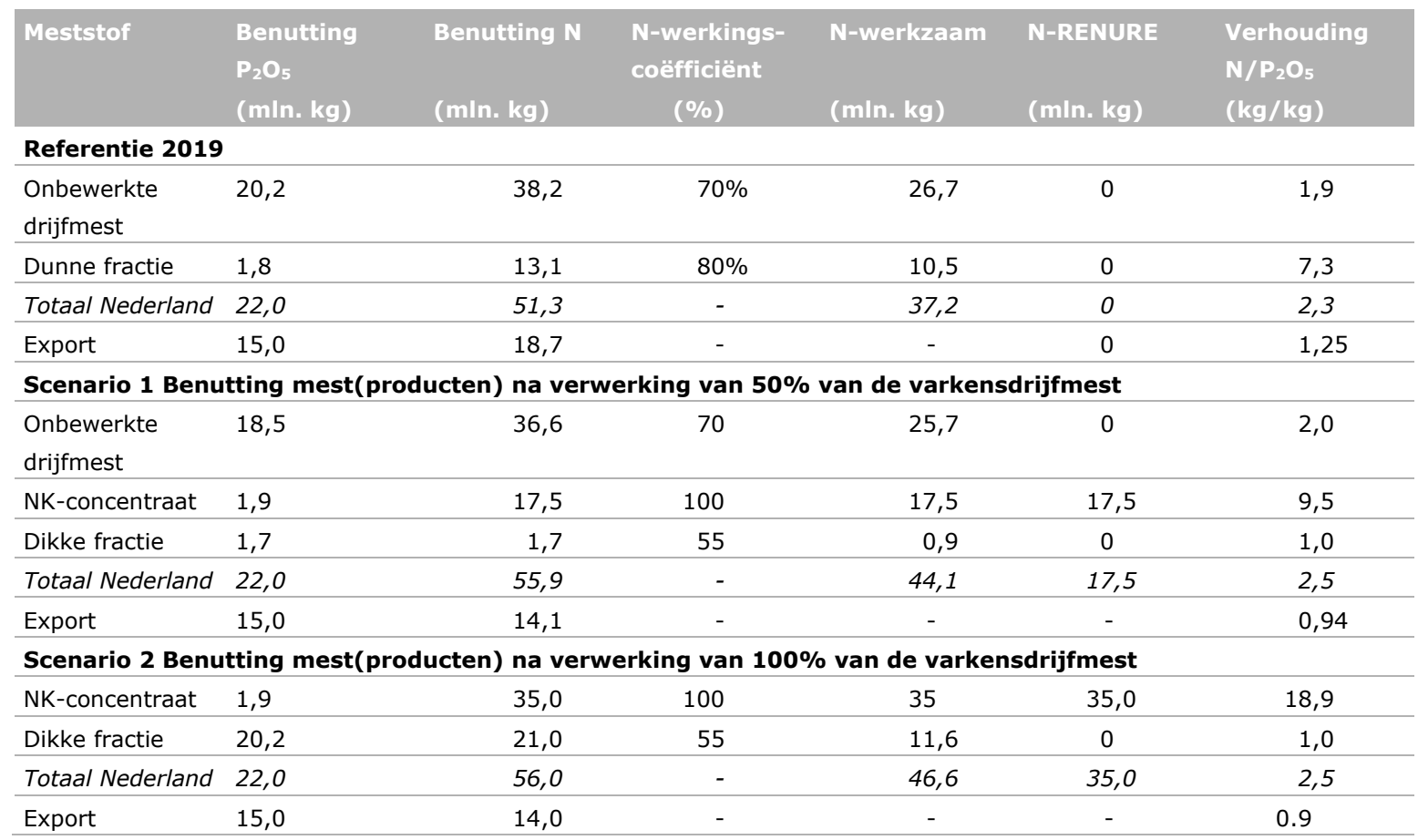

In scenario 1 wordt $50 \%$ van de varkensmest verwerkt tot NK-concentraat, resulterend in $18 \mathrm{mln}$. $\mathrm{kg}$ $\mathrm{N}$, dat als kunstmestvervanger wordt toegepast. Daarnaast wordt varkensdrijfmest toegepast. De export van mest gaat volledig via dikke fractie. De toename in de benutting van stikstof uit varkensmest stijgt hierbij met 4,6 mln. $\mathrm{kg} \mathrm{N}$ voor totaal $\mathrm{N}$ en met 6,9 mln. $\mathrm{kg} \mathrm{N}$ voor werkzaam $\mathrm{N}$. De netto besparing op kunstmest t.o.v. de referentie bedraagt $6,9 \mathrm{mln}$. $\mathrm{kg} \mathrm{N}$. In scenario 2 wordt alle varkensmest verwerkt tot NK-concentraat en dikke fractie. Er wordt $35 \mathrm{mln} . \mathrm{kg} \mathrm{N}$ als kunstmestvervanger toegepast. De fosfaatgebruiksruimte wordt opgevuld met dikke fractie. Bij dit scenario is de benutting van totaalstikstof gelijk aan scenario 2, terwijl de benutting in termen van werkzaam stikstof $2,5 \mathrm{mln}$. $\mathrm{kg} \mathrm{N}$ toeneemt. De netto besparing op kunstmest t.o.v. de referentie bedraagt 9,3 $\mathrm{mln}$. $\mathrm{kg} \mathrm{N}$.

De doorrekeningen laten zien dat het gebruik van RENURE-materiaal uit varkensmest regionaal behoorlijke hoeveelheden stikstofkunstmest kan vervangen echter, dit voordeel wordt deels tenietgedaan door het niet benutten van de gebruiksruimte voor dierlijke mest elders. De netto besparing op kunstmest binnen de Nederlandse landbouw is daarmee beperkt tot 6,9 tot 9,3 mln. $\mathrm{kg} \mathrm{N}$ bij verwerking van respectievelijk $50 \%$ of $100 \%$ van de varkensmest. Verwerking van varkensmest tot RENURE-materiaal kan daarmee 3,4 tot $4,6 \%$ van het huidige stikstofkunstmestverbruik vervangen.

Economische aspecten rondom de legalisering van het gebruik van RENURE-materiaal zijn eerder doorgerekend door Luesink et al. (2016). Hierin werd geconcludeerd dat effecten op mestafzet beperkt zijn, omdat de markt voor NK-concentraat beperkt is vanwege de hoge K/N-ratio's en de lage concentraties, hetgeen resulteert in hoge transportkosten bij gebruik van NK-concentraat. Een toename in de productie van NK-concentraat zal leiden tot een afname in het aanbod van dunne fractie mest en daarmee mogelijk tot lagere afzetkosten voor dunne fractie mest.

Een onzekerheid is de totale stikstof- en fosfaatuitscheiding door varkens. Tabel 8.3 is doorgerekend op basis van de door het CBS gerapporteerde uitscheiding ( $37 \mathrm{mln} . \mathrm{kg} \mathrm{P}_{2} \mathrm{O}_{5}$ en $70 \mathrm{mln}$. $\mathrm{kg} \mathrm{N}$ ).

Wanneer de data op basis van INITIATOR gebruikt worden, bedraagt de uitscheiding $40 \mathrm{mln}$. $\mathrm{kg} \mathrm{P}_{2} \mathrm{O}_{5}$ 
en $90 \mathrm{mln}$. $\mathrm{kg} \mathrm{N}$ en is het voordeel in termen van stikstofbenutting uit varkensmest bij verwerking tot $\mathrm{NK}$-concentraat groter door de hogere stikstofuitscheiding en een hogere $\mathrm{N} / \mathrm{P}_{2} \mathrm{O}_{5}$-ratio.

\subsection{Conclusies}

- Sinds 2015 is het fosfaatgehalte in de mestexcretie van runderen en varkens gedaald, terwijl de stikstofuitscheiding gelijk bleef. De benuttingsgraad van de fosfaatgebruiksruimte nam af door de stijgende verhouding $\mathrm{N} / \mathrm{P}_{2} \mathrm{O}_{5}$ in rundermest, waardoor het stikstofgehalte en de gebruiksnorm dierlijke mest steeds vaker de aanwending beperken.

- In 2019 bedroeg het fosfaatoverschot uit dierlijke mest $49 \mathrm{mln}$. $\mathrm{kg} \mathrm{P}_{2} \mathrm{O}_{5}$ wanneer rekening is gehouden met de verhouding $\mathrm{N} / \mathrm{P}_{2} \mathrm{O}_{5}$ in de mest en de gebruiksnorm dierlijke mest. Zonder rekening te houden met beperkingen door stikstof zou het fosfaatoverschot $31 \mathrm{mln}$. $\mathrm{kg}_{2} \mathrm{O}_{5}$ bedragen. De in 2019 gerealiseerde afzet buiten de landbouw (export, verwerking, hobby- en natuurterreinen) was nagenoeg voldoende om alle resterende mest binnen de fosfaatgebruiksnorm en gebruiksnorm dierlijke mest te plaatsen.

- Voor varkensmest moest in 2019 circa $41 \%$ van de fosfaatuitscheiding (17 mln. $\mathrm{kg} \mathrm{P}_{2} \mathrm{O}_{5}$ ) en $21 \%$ van de stikstofuitscheiding ( $17 \mathrm{mln} . \mathrm{kg} \mathrm{N}$ ) buiten de landbouw afgezet worden om de resterende mest te plaatsen binnen de landbouw, rekening houdend met het aanbod aan andere mestsoorten en de gebruiksnormen.

- Met de productie van NK-concentraten als kunstmestvervanger wordt beoogd om meer stikstof uit varkensmest binnen Nederland te benutten. Stikstof uit varkensmest wordt reeds voor circa $70 \%$ in Nederland toegepast in de vorm van drijfmest/digestaat en dunne fractie. Vanuit het huidige overschot aan stikstof uit varkensmest kan slechts een beperkte hoeveelheid van circa $7 \mathrm{mln}$. $\mathrm{kg} \mathrm{N}$ $(\approx 3,4 \%$ van het kunstmestverbruik) aan NK-concentraat geproduceerd worden. Dit omdat bij de export van fosfaat uit varkensmest in de vorm van dikke fractie onvermijdelijk ook stikstof wordt geëxporteerd.

- Een hogere productie van NK-concentraat is mogelijk door drijfmest of dunne fractie - die anders in Nederland was benut - op te verwerken tot NK-concentraat. In potentie kan $38 \mathrm{mln}$. kg N $(\approx 16 \%$ kunstmestverbruik) geproduceerd worden wanneer alle varkensmest wordt verwerkt tot NKconcentraat. In de regio van toepassing geeft dit een besparing op het kunstmestgebruik, maar dit heeft nauwelijks invloed op het nationale kunstmestgebruik omdat dit elders zorgt voor vervanging van dierlijke mest door kunstmest. 


\section{Synthese}

\section{$9.1 \quad$ Inleiding}

Mestverwerking is ontstaan vanuit de noodzaak om overschotten aan mest - voornamelijk een overschot aan fosfaat dat niet plaatsbaar is op Nederlandse landbouwgronden - buiten de Nederlandse landbouw af te zetten. Dit rapport richt zich op de verwerking van varkensdrijfmest, omdat de varkenssector niet-grondgebonden is en zodoende een groot deel van de mest laat verwerken.

Sinds de start van dit project in 2017 zijn de mestmarkt en de discussie rondom mestverwerking aan veranderingen onderhevig. Het overschot aan fosfaat uit dierlijke mest is gedaald door een krimp van de veestapel en afnemende fosfaatgehalten in rundermest. In 2019 werd voldoende fosfaat uit varkensmest geëxporteerd om de resterende mest te plaatsen binnen de gebruiksnormen voor fosfaat en stikstof uit dierlijke mest. Verwacht wordt dat de mestproductie de komende jaren verder zal dalen, terwijl de mestverwerkingscapaciteit ondertussen groeit door de opstart van nieuwe grote mestverwerkers. Dit leidt bij een aantal verwerkers tot een afname in het aanbod van mest. Gelijktijdig is de politieke discussie rondom mestverwerking verbreed naar andere maatschappelijke functies en wordt mestverwerking gezien als onderdeel van de oplossing om emissies van broeikasgassen $\left(\mathrm{CO}_{2}\right.$ en methaan) uit mest te verminderen. Ook wordt mestverwerking opgevat als een instrument om emissies van ammoniak te beheersen. Zo wordt in de kamerbrief 'Routekaart Toekomstig Mestbeleid' gesproken over stimulering van het gebruik van RENURE-materialen en een andere definitie van mestverwerking gericht op de transitie naar kringlooplandbouw, het reduceren van emissies en volledige verwerking van mest van niet-grondgebonden bedrijven. Om de productie van kunstmestvervangers te verhogen, wordt beoogd om in het najaar van 2021 een subsidieregeling te starten.

Deze ontwikkelingen leiden tot een kennisbehoefte over de toekomstige definitie van mestmestverwerking en de bijdrage van mestverwerking aan het behalen van maatschappelijke doelen, waaronder reductie van stikstof- en broeikasgasemissies. Binnen het TKI PPS-project 'Meerwaarde Mest en Mineralen 2: nutriënten terugwinning uit mest' is op deze behoefte ingegaan door de initiële kennisvraag - gericht op verwaarding van overschotten aan fosfaat - te verbreden naar een volledige evaluatie van deelnemende grootschalige mestverwerkers.

Hiervoor zijn vijf mestverwerkers, alle gesitueerd in de mestconcentratiegebieden en met een bedrijfseigen aanpak voor de verwerking van mest en afzet van de mestproducten, gemonitord en geëvalueerd. Op de bedrijven zijn twee tot acht monitoringsronden uitgevoerd om de scheidingsrendementen van alle processtappen vast te stellen, wat heeft geleid tot gedetailleerde massabalansen (hoofdstuk 3) en een evaluatie van de mestproducten in relatie tot de agronomische behoefte en milieukundige criteria (hoofdstuk 5). In combinatie met aanvullende informatie en data van de verwerkers is vervolgens de kostprijs voor een viertal mestverwerkingsscenario doorgerekend (hoofdstuk 6) en is een milieukundige evaluatie uitgevoerd met de nadruk op de $\mathrm{CO}_{2}$-voetafdruk van specifieke mestverwerkingsscenario's (hoofdstuk 7). Hoofdstuk 8 geeft een overzicht van de recente ontwikkelingen in de stikstof- en fosfaatbalansen in de Nederlandse landbouw.

\subsection{Verwerking van fosfaat}

\subsubsection{Dikke fractie of korrels}

Het mestoverschot is primair een overschot aan fosfaat en in mindere mate een overschot aan stikstof. Voor varkensmest moet circa $40 \%$ van het fosfaat buiten de Nederlandse landbouw worden afgezet, terwijl $80 \%$ van de stikstof - in de vorm van dunne fractie of drijfmest - in Nederland plaatsbaar is binnen de gebruiksruimte dierlijke mest (data 2019). 
Door mestscheiding ontstaan mestproducten die gerichter kunnen worden ingezet in een bemestingsplan en waarbij stikstof zo veel mogelijk binnen Nederland wordt benut. Om het exportvolume van mest te verlagen, voeren bedrijven een dik-dunscheiding uit met een zeefbandpers of decanter centrifuge waarmee $65 \%$ tot $99 \%$ van het fosfaat wordt afgescheiden als een dikke fractie met een drogestofgehalte van circa 30\%. Hiermee wordt de te exporteren mestmassa verlaagd tot circa $20 \%$ van de ingaande mest of de ingaande co-vergiste mest (digestaat). Omdat bij export alleen de dikke fractie gehygiëniseerd hoeft te worden, geeft dit tevens een voordeel in het energieverbruik ten opzichte van export van drijfmest. Ecoson verwerkt de dikke fractie tot een mestkorrel, waardoor de te exporteren massa afneemt tot $6 \%$ van de ingaande mestmassa. Hierbij wordt gebruikgemaakt van restwarmte van de biogasmotor. Een dergelijke businesscase is alleen haalbaar indien voldoende restwarmte beschikbaar is.

Om hoge scheidingsrendementen te behalen, worden polymeren op basis van polyacrylamide toegevoegd. Daarnaast voegt een deel van de verwerkers ijzersulfaat toe om het scheidingsrendement voor fosfaat te verhogen en om te kunnen voldoen aan de voorwaarden voor de productie van een mineralenconcentraat (verhouding stikstof/fosfaat $=\mathrm{N} / \mathrm{P}_{2} \mathrm{O}_{5} \geq 15$ ). Het gebruik van ijzersulfaat leidt tot verhoogde sulfaatgehalten in de dunne fractie of het NK-concentraat. Ook leidt het tot verhoogde ijzergehalten in de dikke fractie, al is het effect hiervan op de gewasbeschikbaarheid van fosfaat bij de gebruikte doseringen beperkt. Er zijn verschillen in het type en de doseringshoogte van toegevoegde chemie tussen de deelnemende verwerkers. Groot Zevert Vergisting (GZV) voegt bijvoorbeeld geen ijzerzout toe in het proces, met als consequentie dat het fosfaatgehalte van het NK-concentraat de gewenste $0,1 \mathrm{~g} / \mathrm{kg}$ overschrijdt. GZV experimenteert zodoende met alternatieven op basis van magnesiumzouten.

Ook in vergistingsinstallaties kan ijzerzout of ijzerwater gedoseerd worden ter beheersing van $\mathrm{H}_{2} \mathrm{~S}$ gehalten in biogas. De aan deze studie deelnemende bedrijven met een vergister hebben een ontzwavelingsinstallatie voor biogas en doseren geen ijzer in het vergisteringsproces. Dit is gunstig voor de fosfaatbeschikbaarheid van de meststof, die negatief beïnvloed wordt door dosering van ijzer (Regelink en Rietra, 2021). Echter, zonder ijzertoevoeging bestaat het risico dat het digestaat en de daaruit gemaakte vloeibare eindproducten nog tijdens de vergisting gevormd $\mathrm{H}_{2} \mathrm{~S}$ bevatten. $\mathrm{H}_{2} \mathrm{~S}$ is bij concentraties van enkele ppm in de ingeademde lucht al giftig, wat resulteert in veiligheidsrisico's (zie paragraaf 5.2.4). Risico's op blootstelling van medewerkers aan $\mathrm{H}_{2} \mathrm{~S}$ treden op wanneer het digestaat of de daaruit gemaakte eind- of tussenproducten worden gemixt, verpompt of de uitwisseling van opgelost waterstofsulfide met de lucht op andere manieren wordt bevorderd.

Het gebruik van bovengenoemde chemie is niet van invloed op de marktwaarde van dikke fractie waardoor een stimulans voor de verwerker ontbreekt om dergelijke producten te vermijden. Indien de verwerker voornemens is om de dikke fractie te exporten onder een CE-markering, vormt de toevoeging van polymeer een knelpunt. Dit omdat verwacht wordt dat louter volledig biologisch afbreekbare polymeren worden toegelaten als additief onder de nieuwe EU-meststoffenwetgeving. Afzetkosten voor gehygiëniseerde dikke fractie zijn de laatste jaren sterk gedaald van circa $€ 25$ per ton naar circa $€ 18$ per ton. Er is voldoende vraag naar de dikke fractie van varkensmest en de voornaamste afnemers, boeren in Noord-Frankrijk en Duitsland, zijn bereid ervoor te betalen.

\subsubsection{Opwerking tot veenvervanger en fosfaatmeststof}

In het kader van dit project is met GZV en Nijhuis Industries een grootschalige installatie ontwikkeld, geïnstalleerd en gemonitord waarmee dikke fractie van digestaat wordt gescheiden in een fosfaatarme organische stof en een fosfaatmeststof. De installatie werkt via het RePeat-proces (Recovery of P to eat). Dikke fractie van digestaat wordt tweemaal gespoeld met een proceswater aangezuurd tot $\mathrm{pH}$ 5,5 , waarbij circa $85 \%$ van het fosfaat in oplossing komt. De resterende organische stof is vanwege het lage fosfaatgehalte en hoge organische stofgehalte een aantrekkelijke bodemverbeteraar en wordt onder de merknaam 'Groene Effectieve Bodemverbeteraar' (GEB) in de landbouw afgezet. De installatie is uitgebreid met een derde spoelstap waarin de GEB gespoeld wordt met water ter verlaging van het zwavelgehalte en afstemming ervan op de gewasbehoefte. 
De fosfaatrijke vloeistof reageert in een fosfaatprecipitatietank met kalkmelk waarbij fosfaat precipiteert en uitzakt. Het huidige proces produceert een verpompbaar fosfaatslib - het fosfaatprecipitaat - met een drogestofgehalte van circa $20 \%$. Vanuit prijsoverwegingen en om zoutaanslag te vermijden, is besloten om te starten met dosering van kalkmelk, terwijl uit eerdere proeven bekend is dat het duurdere magnesiumhydroxide - waarbij struviet wordt gevormd - een aanzienlijk betere ontwatering geeft. In 2021 zal GZV inzetten op productie van struviet om een drogere fosfaatmeststof te produceren. Hoog chemieverbruik en kosten zijn een knelpunt bij de installatie.

Bij aanvang van dit TKI-project was het doel om een fosfaatarme bodemverbeteraar te produceren voor afzet in de landbouw. In de tussentijd zijn er echter ook nieuwe afzetroutes ontwikkeld, waarbij de fosfaatarme organische stof wordt benut als veenvervanger in substraten voor champignonteelt en voor de productie van potgrond. Bij gebruik in potgrond vereist dit een extra spoelstap om het zoutgehalte (zwavelgehalte) te verlagen, terwijl een hoog zout- en zwavelgehalte voor afdekaarde of substraat in de champignonteelt geen belemmering vormt. Er is een zeer grote interesse vanuit de industrie om alternatieve grondstoffen voor veen te testen en te ontwikkelen, omdat er doelstellingen zijn om het gebruik van veen drastisch terug te dringen. Veen is immers een fossiele grondstof en het afgraven en de daaropvolgende biologische afbraak van veen geeft broeikasgasemissies en leidt tot vernietiging van natuurgebieden. Marktpartijen in Nederland betalen circa $€ 25$ per $\mathrm{m}^{3}$ veen. Voor GZV biedt de afzet als veenvervanger diverse voordelen, waaronder een hoge marktwaarde en jaarrond afzet van de volledige productie. Deze afzetroute is daarmee zowel voor producent als afnemer perspectiefvol.

Het fosfaatprecipitaat wordt op dit moment afgezet in de Nederlandse landbouw naar akkerbouwers. In de regio is vraag naar fosfaatmeststoffen op derogatiebedrijven, maar omdat het fosfaat zijn herkomst kent uit varkensmest, is deze toepassing niet toegestaan. Er is vanuit de markt voldoende interesse in afname van het fosfaatprecipitaat mits deze verder wordt ontwaterd, zodat deze geschikt is als grondstof voor mestkorrels. De doorontwikkeling van beide producten loopt verder in het nieuwe TKI-project BIOVALOR, dat in 2021 van start is gegaan. Productie van hoogwaardige producten met een voldoende hoge marktwaarde is een voorwaarde voor het realiseren van een positieve businesscase voor het proces.

\subsection{Stikstofverwaarding}

Circa 70\% van de stikstof uit varkensmest werd in 2019 benut binnen de Nederlandse landbouw, grotendeels in de vorm van drijfmest of dunne fractie onder de gebruiksnorm dierlijke mest (57 mln. $\mathrm{kg} \mathrm{N})$ en een klein deel in de vorm van NK-concentraat $(2,5 \mathrm{mln} . \mathrm{kg} \mathrm{N})$ als kunstmestvervanger (hoofdstuk 8). NK-concentraat kan onder voorwaarden benut worden als kunstmestvervanger boven op de gebruiksnorm dierlijke mest. Dit wordt op het moment geregeld via tijdelijke vrijstellingen (pilot Mineralenconcentraten en pilot Kunstmestvrije Achterhoek), maar een generieke vrijstelling is voorzien vanaf 2022, mits de Europese Commissie instemt met de inpassing van RENURE-materialen onder de Nitraatrichtlijn.

Alle onderzochte NK-concentraten voldoen aan de RENURE-criteria $\left(\left(\mathrm{N}-\mathrm{NH}_{4}+\mathrm{N}-\mathrm{NO}_{3}\right) / \mathrm{N} \geq 90 \%\right.$ en $\mathrm{TOC} / \mathrm{N} \leq 3,0)$. Ook de dunne fractie na behandeling met DAF of microfiltratie voldoet al aan de RENURE-criteria. Het is echter onwaarschijnlijk dat dunne fracties ook in aanmerking komen voor toepassing als RENURE-materiaal, omdat een dunne fractie niet voldoet aan de procesdefinitie waarin gesteld wordt dat sprake moet zijn van het op-concentreren van de meststof. NK-concentraten ontstaan na indikking van dunne mestvloeistof op een RO-installatie, waarbij de mestvloeistof een factor 2 tot 3 wordt ingedikt. Het stikstofgehalte van NK-concentraat $(<1 \%)$ is laag ten opzichte van synthetische stikstofmeststoffen. De indikkingsfactor is een bedrijfseconomische afweging tussen kosten voor chemie- en energieverbruik en baten van volumereductie op transport en de opslag buiten het bemestingsseizoen. NK-concentraat wordt afgezet in de regio van de verwerker en voorkomt daarmee langeafstandstransport van mest of dunne fractie naar akkerbouwgebieden. 
Indien de verwerkingsinstallatie nabij akkerbouwgebied ligt, zoals bij Loonbedrijf Dekker in Putten, biedt opwerking tot NK-concentraat geen duidelijke voordelen boven die van afzet van dunne fractie. Dunne fractie wordt binnen de gebruiksnorm dierlijke mest met een stikstofwerkingscoëfficiënt van $80 \%$ toegepast en is door lage fosfaatgehalten goed in te passen in het bemestingsplan. De operationele en investeringskosten voor scheiding in dikke en dunne fractie zijn relatief laag. Ook bewegen de afzetkosten voor dunne fractie mee met de prijs voor drijfmest waardoor een verandering in het poorttarief doorwerkt naar de afzetkosten van de dunne fractie. Naar schatting biedt opwerking tot NK-concentraat waaraan een stikstofwerkingscoëfficiënt van $100 \%$ wordt gegeven, economische voordelen bij een transportafstand voor dunne fractie van > $100 \mathrm{~km}$ (hoofdstuk 6). Hetzelfde geldt voor het voordeel in termen van $\mathrm{CO}_{2}$-emissies: opwerking tot $\mathrm{NK}$-concentraat biedt voordelen in termen van $\mathrm{CO}_{2}$-emissies indien hiermee lange-afstandstransport voorkomen wordt.

Door gebruik van NK-concentraat als kunstmestvervanger wordt in regio's met intensieve veehouderij het kunstmestgebruik verlaagd. Echter, het effect op het totale kunstmestverbruik in de Nederlandse landbouw is beperkt, ook indien alle varkensmest verwerkt zou worden tot NK-concentraat. Dit komt omdat reeds $70 \%$ van de stikstof uit varkensmest benut wordt binnen de Nederlandse landbouw in de vorm van drijfmest of dunne fractie mest. Opwerking van dunne fractie tot NK-concentraat leidt tot een evenredige daling in het gebruik van stikstof uit dunne fractie, waardoor er netto gezien nauwelijks besparing van kunstmest optreedt. Ten opzichte van export van drijfmest levert productie van NK-concentraat wel een besparing op in het kunstmestgebruik. Uit de hoeveelheid varkensmest die in 2019 werd geëxporteerd ( $22 \mathrm{mln}$. $\mathrm{kg} \mathrm{N}$ ), kan circa $7 \mathrm{mln}$. kg N in de vorm van een RENUREmateriaal gewonnen worden, wat gelijk staat aan 3,4\% van het kunstmestverbruik in Nederland.

Een aandachtspunt bij de aanwending van NK-concentraten is het gehalte aan zwavel en kalium. NKconcentraten bevatten verhoogde gehalten aan zwavel door toevoeging van zwavelzuur op ROinstallaties waar het wordt gebruikt om de $\mathrm{pH}$ van de mestvloeistof te verlagen tot $\mathrm{pH}<8$. Dit zodat $\mathrm{N}-\mathrm{NH}_{4}$ nagenoeg volledig aanwezig is als $\mathrm{NH}_{4}{ }^{+}$en daardoor het RO-membraan niet kan passeren. Ook de toevoeging van ijzersulfaat - om een voldoende laag fosfaatgehalte van het NK-concentraat te realiseren - draagt bij aan verhoogde zwavelgehalten in het NK-concentraat. Er zijn tussen de verwerkers grote verschillen in de hoogte van het zwavelgehalte $(1,6-5,4 \mathrm{~g} / \mathrm{kg})$ van het NKconcentraat door verschillen in het type en de doseringshoogte van toegevoegde chemie. Bij aanwending van NK-concentraten met een hoog zwavelgehalte t.o.v. het stikstofgehalte wordt meer zwavel gegeven dan het gewas nodig heeft. Dit leidt tot uitspoeling van zwavel (sulfaat) naar het grondwater en tot risico's op een verlaagde gewasopname van sporenelementen. Daarnaast vormt zwavel een risico op vorming van het giftige gas $\mathrm{H}_{2} \mathrm{~S}$ (dodelijk bij blootstelling boven $100 \mathrm{ppm}$ ). Het mengen van NK-concentraat met drijfmest wordt daarom vanuit veiligheidsoverweging ontraden. Kalium in NK-concentraat is louter afkomstig vanuit de drijfmest en er zijn weinig verschillen tussen de verwerkers in de verhouding stikstof/kalium in NK-concentraat. Ook voor kalium geldt dat rekening gehouden moet worden met de gewasbehoefte om nadelige effecten (zoals kopziekte bij runderen) te voorkomen. NK-concentraten worden toegepast boven op de basisgift aan dierlijke mest, waarbij die basisgift meestal al voorziet in de gewasbehoefte aan zwavel en kalium. Blenden van NK-concentraat met andere stikstofmeststoffen vormt een mogelijkheid om een bemestingsproduct op maat te maken waarmee bovenstaande risico's beheersbaar worden. Een voorbeeld hiervan is de 'Groene Weide Meststof' (GWM), geproduceerd door GZV.

\subsection{Emissies van broeikasgassen en ammoniak}

Mestverwerking kan bijdragen aan het terugdringen van methaanemissies uit mestkelders door de mest maandelijks bij de veehouder op te halen en de mest vervolgens te vergisten en/of te scheiden in een dikke en dunne fractie. Maandelijkse afvoer van mest naar de verwerker is reeds de praktijk indien de mest onder contract wordt afgezet. Het voordeel dat behaald kan worden door het verminderen van methaanemissies uit mestkelders van veehouders is, in $\mathrm{CO}_{2}$-equivalenten, groot ten opzichte van de $\mathrm{CO}_{2}$-emissie gerelateerd aan mestscheiding en mesttransport.

Uit de evaluatie blijkt verder dat scheiding van mest tot een dikke fractie en NK-concentraat leidt tot een lagere of gelijke $\mathrm{CO}_{2}$-voetafdruk ten opzichte van export van ongescheiden drijfmest of digestaat 
over een afstand van $250 \mathrm{~km}$. De vermindering in $\mathrm{CO}_{2}$-emissies door vermeden transport weegt op tegen de extra $\mathrm{CO}_{2}$-emissies van elektriciteitsverbruik voor scheiding en opwerking. Dit geldt ook voor reguliere scheiding van mest in een dikke en dunne fractie. Bij bedrijven die co-vergisting toepassen, is de biogasproductie daarnaast van grote invloed op de $\mathrm{CO}_{2}$-voetafdruk en wordt gebruik van fossiel gas voor de hygiënisatie vermeden door gebruik van restwarmte. Co-producten en ongeboren mest dragen sterk bij aan de productie van biogas en dragen bij aan de beschikbaarheid van voldoende restwarmte om aan de energievraag van de vergistingsinstallatie en hygiënisatie te kunnen voldoen.

NK-concentraten kenmerken zich door een $\mathrm{pH}$ van 8 of hoger waardoor ammoniakemissies kunnen ontstaan. Emissiearme opslag en aanwending zijn daarmee noodzakelijk om emissies te beheersen en tevens ook verplicht onder RENURE. Aanwendingsemissies van ammoniak zijn lager voor NKconcentraat dan voor drijfmest, omdat NK-concentraat vanwege de lagere viscositeit sneller in de grond infiltreert. Dit geldt naar verwachting niet voor een mengsel van NK-concentraat met drijfmest. Toepassing van NK-concentraat op grasland via zodenbemesting geeft een hogere emissie van ammoniak ten opzichte van de kunstmeststof kalkammonsalpeter (KAS), terwijl de emissie bij aanwending op bouwland via mestinjectie ( $>5 \mathrm{~cm}$ diep) ongeveer gelijk is aan die voor KAS. Oppervlakkige aanwending op beteeld bouwland wordt afgeraden om ammoniakemissies te voorkomen. Verder onderzoek is nodig om emissiefactoren van dergelijke nieuwe meststoffen nauwkeuriger vast te stellen. Indien het uitgangspunt is dat alle mest van niet-grondgebonden bedrijven wordt verwerkt, moet rekening worden gehouden met een toenemend gebruik van dikke fracties binnen Nederland en bijbehorende ammoniakemissies, met name op grasland, omdat de dikke fractie daar niet ondergewerkt kan worden. Vanuit het oogpunt van ammoniakemissies wordt aangeraden om ook perspectieven voor productie van nitraatmeststoffen uit dierlijke mest te verkennen.

\subsection{Aanbevelingen}

- Tussen mestverwerkers zijn grote verschillen in het chemieverbruik voor de productie van diverse meststoffen. Aanbevolen wordt om aanvullend onderzoek te starten naar mogelijkheden voor efficiënter gebruik van chemie in het verwerkingsproces en kennisuitwisseling tussen verwerkers te stimuleren; dit met het oog op verlaging van het zwavelgehalte van NK-concentraat. Ook wordt aanbevolen alternatieven te onderzoeken voor polymeren op basis van polyacrylamide. Dit om meststoffen te kunnen produceren die met een CE-label verhandeld kunnen worden onder de nieuwe EU-meststoffenwetgeving.

- Mengen van NK-concentraat met drijfmest moet worden ontmoedigd omdat separate aanwending van NK-concentraat tot lagere ammoniakemissies leidt. Daarnaast zijn er NK-concentraten op de markt met hoge zwavelgehalten waarbij mengen met drijfmest voorafgaand aan opslag leidt tot verhoogde risico's op emissie van het giftige gas $\mathrm{H}_{2} \mathrm{~S}$.

- Het verruimen van mogelijkheden tot blenden van NK-concentraat met andere stikstofmeststoffen (herwonnen of van synthetische oorsprong) tot een meststof op maat wordt aanbevolen, omdat hiermee overbemesting met zwavel en kalium wordt voorkomen. Daarbij moet vooraf met metingen getoetst worden of de meststoffen veilig gemengd kunnen worden zonder dat daardoor schadelijke gassen worden gevormd. Het vaststellen van emissies bij blending van meststoffen, voorafgaand aan opslag, vraagt om optimalisatie van meetmethoden (Bijlage 3).

- De feitelijke emissies van broeikasgassen en ammoniak bij mestverwerking en aanwending van verwerkingsproducten zijn voor Nederlandse omstandigheden nauwelijks bekend. Aanbevolen wordt om deze verliezen via een monitoringsprogramma nader te kwantificeren.

- Het verkorten van de opslagduur van drijfmest in mestkelders is relatief eenvoudig te realiseren door de mest maandelijks te laten afvoeren naar een verwerker, waarna de drijfmest middels vergisting en/of scheiding bewerkt wordt. 
- Indien Nederland, net als Vlaanderen, verplichte debietmeters op mestverwerkingsinstallaties wil introduceren ter voorkoming van mestfraude, dan is het aan te raden om vooraf de nauwkeurigheid van een dergelijke massabalansmethode vast te stellen.

- Emissies van ammoniak zijn een aandachtspunt bij gebruik van NK-concentraat. Om mestverwerking in te zetten als middel om landbouwemissies van ammoniak terug te dringen, moeten emissiearme meststoffen geproduceerd worden. Voorbeelden zijn lichtzure meststoffen zoals ammoniumnitraat of ammoniumsulfaat, waarbij de laatste nadeliger is vanwege het hoge zwavelgehalte. Ook productie van KAS uit mest is technisch mogelijk. Toepassingen waarbij stikstof uit mest buiten de landbouw wordt afgezet, verdienen verdere aandacht, omdat deze routes bijdragen aan het terugdringen van ammoniakemissies uit de landbouw. Een voorbeeld hiervan is de vraag naar ammoniakwater voor de industriële rookgasreiniging van o.a. afvalverbrandingsinstallaties.

- Verdere ontwikkeling van de kringlooplandbouw en overgang naar meer verplichte mestverwerking vraagt om een assessment van de milieuvoordelen bij verwerking van niet-overschotsmest en tevens om nieuwe verdienmodellen waarbij ook andere maatschappelijke voordelen beloond worden. 


\section{Conclusies \& vooruitblik}

De evaluatie van vijf grootschalige mestverwerkers leert dat verwerkers hun proces hebben aangepast aan locatie- en regio-specifieke omstandigheden, zoals het type gevraagde meststoffen in de regio en de beschikbaarheid van restwarmte uit een biogasmotor of andere bedrijfsactiviteiten. Bij covergistingsinstallaties is er sprake van verstrengeling van bedrijfsactiviteiten (productie van biogas en verwerking van digestaat). De digestaatverwerking profiteert daarbij van de beschikbaarheid van restwarmte vanuit de omzetting van biogas naar elektriciteit. Door de grote verschillen tussen de mestverwerkers en verschillen in het ingaande materiaal door het al dan niet toevoegen van coproducten, is een vergelijking van prestatiekenmerken niet eerlijk zonder de verwerkingsprocessen in de juiste context te beschouwen. Zo is bijvoorbeeld de opwerking van dunne fractie tot NKconcentraat een logische keuze voor een verwerker in een mestconcentratiegebied, maar biedt deze route weinig tot geen voordeel voor verwerkers die dunne fractie op relatief korte afstand kunnen afzetten. Een hoge productie aan loosbaar water is een voordeel in termen van minder af te voeren meststoffen, maar dit effect is van ondergeschikt belang wanneer de bulk van de meststoffen als kunstmestvervanger binnen de regio wordt aangewend. In dat geval kan een lagere waterproductie ook een keuze zijn om minder geconcentreerde meststoffen te maken om daarmee zoutschade en ammoniakemissies bij aanwending te beperken.

Voor alle deelnemende verwerkers die een NK-concentraat produceren voldoet deze meststof aan de, door het JRC, voorgestelde criteria voor RENURE-materialen en wordt het NK-concentraat reeds onder een tijdelijke vrijstelling aangewend als kunstmestvervanger. RENURE-criteria hebben betrekking op het aandeel mineraal stikstof ( $\mathrm{N}-\mathrm{min} / \mathrm{N} \geq 90 \%$ en $\mathrm{TOC} / \mathrm{N} \leq 3,0$ ). Voor de landbouwpraktijk zijn daarnaast ook andere parameters relevant, waaronder het gehalte aan kalium en zwavel en de $\mathrm{pH}-$ waarde. De samenstelling van NK-concentraten wordt o.a. beïnvloed door het toevoegen van chemie (o.a. zwavelzuur, ijzersulfaat en magnesiumchloride). Door verschillen in het type en de doseringshoogte van toegevoegde chemie ontstaan verschillen in de samenstelling van NKconcentraat tussen de verwerkers. Het kalium- en zwavelgehalte zijn een aandachtspunt bij inpassing in het bemestingsplan, omdat deze bij bemestingsgiften boven de gewasopname nadelige effecten kunnen hebben voor gewas, vee of milieu. Zwavelgehalten zijn deels te verlagen door terugdringen van het chemieverbruik. Daarnaast wordt aanbevolen om de gebruiksmogelijkheden voor blenden van NK-concentraat met andere stikstofmeststoffen tot kunstmeststikstofvervanger te verruimen. Dit zodat de verwerker in staat wordt gesteld om een meststof op maat te produceren, waarbij de nutriëntengehalten passen bij de gewasbehoefte. Een voorbeeld hiervan is de 'Groene Weide Meststof' van GZV, bestaande uit een blend van NK-concentraat, urean en/of herwonnen ammoniumsulfaatoplossing. Het blenden van NK-concentraat met drijfmest wordt daarentegen ontraden vanwege verhoogde aanwendingsemissies van ammoniak ten opzichte van separate aanwending van NK-concentraat. Ook geeft blenden van NK-concentraat met drijfmest voorafgaand aan opslag ervan risico's op vorming en emissie van het toxische waterstofsulfide $\left(\mathrm{H}_{2} \mathrm{~S}\right)$.

In de laatste jaren is de politieke aandacht voor de rol van mestverwerking voor andere maatschappelijke doelen, waaronder het terugdringen van emissies van broeikasgassen en ammoniak, toegenomen. Mestverwerking kan een grote bijdrage leveren aan het verminderen van methaanemissies uit mestkelders en mestopslagen door de mest maandelijks of vaker bij de veehouder op te halen en vervolgens te vergisten en/of te scheiden in een dikke en dunne fractie. Mestverwerking heeft daarnaast een lagere $\mathrm{CO}_{2}$-voetafdruk ten opzichte van langeafstandstransport van ongescheiden drijfmest of ongescheiden digestaat, omdat de voordelen voor vermindering van mesttransport opwegen tegen het energieverbruik van de installaties. In termen van stikstofemissies zijn effecten niet eenduidig. NK-concentraat kenmerkt zich door een hoge $\mathrm{pH}$ en de emissiefactor voor aanwending van ammoniak is op basis van de beperkte beschikbare data lager dan die voor drijfmest, maar hoger dan die voor KAS-kunstmest. Indien, bij een toekomstige daling van het fosfaatoverschot, ook de dikke fractie na mestscheiding binnen Nederland wordt aangewend, kan dit leiden tot een toename in de ammoniakemissie. Er zijn ook verwerkingstechnieken waarbij stikstof niet naar de 
landbouw wordt teruggebracht en daardoor geen aanwendingsemissies veroorzaakt. Stikstof wordt in plaats daarvan biologisch afgebroken (Ecoson) of zal worden teruggewonnen in de vorm van ammoniakwater ten behoeve van industriële rookgasreiniging (Twence, vanaf 2022) waar het synthetisch ammoniakwater vervangt. Voor deze twee verwerkingsinstallaties kon geen volledige evaluatie van de milieueffecten worden uitgevoerd.

In het kader van de transitie naar een 'kringlooplandbouw' waarbij beschikbare mest en reststromen binnen de landbouw worden benut, is er aandacht voor NK-concentraat als alternatief voor stikstof- en kalikunstmest. Door export van stikstof uit varkensmest te vervangen door opwerking tot een RENURE-materiaal kan circa $7 \mathrm{mln}$. kg N uit varkensmest als kunstmeststikstofvervanger benut worden. Dit zal hoofzakelijk toepassing vinden in regio's met intensieve veehouderij waar een deel van de kunstmestbehoefte kan worden vervangen. Er kan meer kunstmest vervangen worden door ook de dunne fractie of drijfmest, welke nu binnen Nederland wordt toegepast, op te werken tot een RENUREmateriaal, maar dit leidt alleen regionaal tot veranderingen in de aanwending van meststoffen en heeft geen effect op het totale kunstmestverbruik binnen de Nederlandse landbouw.

Er wordt verwacht dat de daling in de uitscheiding van fosfaat en stikstof door de Nederlandse veestapel zich de komende jaren verder doorzet door maatregelen in het kader van de zogenoemde Stikstofwet. ${ }^{27}$ De huidige mestverwerkingsplicht is gekoppeld aan het overschot aan fosfaat binnen de landbouw en dit maakt de toekomst voor mestverwerkers onzeker. Bij een dalend fosfaatoverschot kan hoogwaardige verwerking van mest of digestaat niet concurreren met afzet van onbewerkte drijfmest binnen de Nederlandse landbouw. Om nieuwe vormen van mestverwerking te realiseren, zijn tevens nieuwe verdienmodellen nodig waarin ook andere maatschappelijke voordelen van mestverwerking, zoals het terugdringen van methaan- en ammoniakemissies, beloond worden.

\footnotetext{
${ }^{27}$ Wet stikstofreductie en natuurverbetering en Besluit stikstofreductie en natuurverbetering
} 


\section{Literatuur}

Bruggen, C. van, A. Bannink, C.M. Groenestein, J.F.M. Huijsmans, L.A. Lagerwerf, H.H. Luesink, S.M. van der Sluis, G.L. Velthof \& J. Vonk (2018). Emissies naar lucht uit de landbouw in 2016. Berekeningen met het model NEMA. Wageningen, WOT Natuur \& Milieu, WOt-technical report 119. 124 pp.; 48 tab.; 6 figs.; 65 ref.; 7 bijl.

Bruggen, C. van, A. Bannink, C.M. Groenestein, J.F.M. Huijsmans, L.A. Lagerwerf, H.H. Luesink, G.L. Velthof \& J. Vonk (2021). Calculations using the NEMA model. Wageningen, Statutory Research Tasks Unit for Nature and the Environment (WOT Natuur \& Milieu). WOt-technical report 178. 224 p; 25 Tab.; 8 Fig.; 74 Ref.; 32 Annexes.

Commissie Deskundigen Meststoffenwet (CDM), 2014. Advies "Bemesting met zwavelhoudende meststoffen" https://edepot.wur.nl/459071

Commissie Deskundigen Meststoffenwet (CDM). 2013. Beoordeling mestproducten op basis van het Protocol Gebruiksvoorschriften Dierlijke Mest, versie 1.0. https://www.wur.nl/upload_mm/f/4/6/3dc5f81d-0857-44ac-91ec-cb5b97d493d8_13NM0029\%200ene\%200enema\%20bijlage\%201\%20update\%20corrected.pdf

Dai,X.R., Blanes-Vidal, V., 2013. Emissions of ammonia, carbon dioxide, and hydrogen sulphide from swine wastewater during and after acidification treatment: Effect of $\mathrm{pH}$, mixing and aeration. J. Environ. Manage. 115, 147-154. https://doi.org/10.1016/j.jenvman.2012.11.019

Dijk, W. Van., Postma, R., Gollenbeek, L.R., Mostert, P., NCM, J, Verdoes, N. 2020. Behoefte aan mestbewerkingsproducten in Nederland en Europa. Wageningen Research Report WPR-1011. https://doi.org/10.18174/528800

Dijk, W. Van, Van Der Voort, M., Van Middelkoop, J., De Ruijter, F., Van Reuler, H., 2015. Vergelijking van verschillende verwerkingsmethoden van dunne mest ten aanzien van duurzaamheid. Wageningen, Praktijkonderzoek Plant\&Omgeving, Rapport PPO 671

Egene et al., Phosphorus speciation in organic fertilisers and implications for their agronomic efficiency as $P$ fertilisers. In voorbereiding.

Ehlert, P.A.I. en W.J. Chardon, 2014. Veranderingen van de zwavelbalans van de Nederlandse bodem. Beantwoording van een helpdeskvraag. Wageningen, Alterra Wageningen UR (University \& Research centre), Alterra-rapport 2516. 48 blz.; 7 fig.; 6 tab.; 59 ref.

Ehlert, P.A.I., 2020. Agronomic efficacy of nitrogen biobased fertilising products of co-digested pig manure. Wageningen. Wageningen Environmental Research report 3033. https://doi.org/10.18174/532699

Fraters, B. and A. De Goffau (2015). Sulfaat in grondwater en oppervlaktewater in Nederland: Overzicht van meetresultaten van nationale meetnetten. RIVM briefrapport 2014-0120. https://www.rivm.nl/bibliotheek/rapporten/2014-0120.pdf

Gollenbeek L.R., J.P.B.F. van Gastel, P.J.T.H. Bussmann, R.W. Melse, N. Verdoes, 2020. Verkenning mogelijke mestverwerkingsroutes en duurzaamheidsaspecten; NL Next Level Mestverwaarden WP2. Wageningen Livestock Research, Openbaar Rapport 1270.

Gollenbeek, L.R., J. van Gastel, F. Casu, N. Verdoes. 2021 (nog niet gepubliceerd). Doorrekenen van economie en emissies voor verschillende scenario's voor verwaarding van varkensmest. Wageningen Livestock Research.

Groenestein, C.M., Mosquera, J., Meise, R.W., 2016. Methaanemissie uit mest. Wageningen Livestock Research, Rapport 961. https://doi.org/http://dx.doi.org/10.18174/401705

Hoeksma, P., de Buisonjé, F.E., Ehlert, P.A.I., Horrevorts, P. 2011. Mineralenconcentraten uit dierlijke mest. Monitoring in het kader van de pilot mineralenconcentraten. Wageningen Livestock Research Rapport 481. https://edepot.wur.nl/177153

Hoeksma, P., H. Schmitt, F. de Buisonjé, H. Pishgar Komleh and P. Ehlert, 2021a. Composition of mineral concentrates. Results of monitoring installations of the pilot mineral concentrate. Wageningen Livestock Research, Report 1295. https://library.wur.nl/WebQuery/wurpubs/580679

Hoeksma, P., H. Schmitt, F. de Buisonjé en P. Sefeedpari, 2021b. Effluenten van mestverwerkingsinstallaties; Wageningen Livestock Research, Rapport 1301 
Huijsmans, J., Hol, J., 2011. Ammoniakemissie bij Toediening van Mineralenconcentraat op Beteeld Bouwland en Grasland. Wageningen Plant Research International Rapport 387

Huygens, D., Orveillon, G., Lugato, E., Tavazzi, S., S., C., Jones, A., Gawlik, B., HGM, S., 2020. Technical proposals for the safe use of processed manure above the threshold established for Nitrate Vulnerable Zones by the Nitrates Directive (91 / 676 / EEC).

https://doi.org/10.2760/373351

Jorgensen, L., Kvist, T. 2015. Methane emissions from Danish biogas plants. Danish Gas Technology Centre.

https://www.dgc.dk/sites/default/files/filer/publikationer/R1502_metanemission_biogasanlaeg.pdf

Klein, J., en G. Roskam. Zware metalen in dierlijke mest in 2017. Deltares. Rapport nr. 11202236-002

Korving, L, Bijleveld, M, Naber, N., Algra, E., 2016. 'Groen' Poly-elektrolyt. STOWA rapport 2016-14. https://www.stowa.nl/sites/default/files/assets/PUBLICATIES/Publicaties\%202016/STOWA\%2020 16-14.pdf

Kros, H., Os, J. Van, Voogd, J.C., Groenendijk, P., Bruggen, C. Van, Ros, G., 2018. Ruimtelijke allocatie van mesttoediening en ammoniakemissie. Wageningen Environmental Research, Rapport 2939. https://doi.org/10.18174/474513 of

Koeijer, T. De, Galen, M. Van, Luesink, H., 2020. Next Level Mestverwaarding - Organisatie en ontwikkeling van de keten. Wageningen, Wageningen Economic Research, nota 2020-085. https://doi.org/10.18174/531980

Luesink, H., Postma, R., Smits, M.-J., Schöll, L. van, Koeijer, T. de, 2016. Effect afzet mestverwerkingsproducten bij wettelijke status kunstmest of EG-meststof. LEI rapport 2016-034. http://dx.doi.org/10.18174/378271

Melsse, R.W., C.M. Groenestein, 2016. Emissiefactoren mestbewerking. Inschatting van emissiefactoren van ammoniak, methaan en lachgas uit mestbewerking. Wageningen, Wageningen Livestock Research Rapport 962

Mosquera, J., R. Schils, K. Groenestein, P. Hoeksma, G. Veltfhof, E. Hummelink. 2010 Emissies van lachgas, methaan en ammoniak uit mest na scheiding. Wageningen Livestock Research rapport 427. https://library.wur.nl/WebQuery/wurpubs/fulltext/161899

NCM, J. 2020. Mestverwerkingsplicht in een veranderende mestmarkt. NCM. www.ncm.nl

NCM, J. 2021. Landelijke rapportage en inventarisatie export en verwerking dierlijke mest. NCM. www.ncm.nl

Regelink, I.C., P. Ehlert, G. Smit, S. Everlo, A. Prinsen, O. Schoumans. 2019. Phosphorus recovery from co-digested animal manure. Development of the RePeat process. Wageningen. Wageningen Environmental Research report 2949.

Regelink, I.C., Rietra, R., 2021. Fosfaatvormen in compost en andere organische meststoffen. Wageningen Environmental Research, Wageningen. https://doi.org/10.18174/541822

Ros, G.H. van Scholl, L, Postma, R. 2014. Marktmogelijkheden voor mestproducten in het oosten van Duitsland. NMI, Wageningen.

Sigurnjak et al., 2021. In voorbereiding. Document on product characteristics, lab results and field trials. In kader van H2020 SYSTEMIC

Schoumans, O.F., P.A.I. Ehlert, W.H. Rulkens en O. Oenema, 2012. Afzetmogelijkheden van de dunne fractie van varkensdrijfmest na mestscheiding. Wageningen, Alterra, Alterra-rapport 2331.

78 blz.; 5 fig.; 14 tab.; 31 ref.

Schoumans et al., 2021. In voorbereiding. Environmental Impact Assessment - SYSTEMIC H2020

Schoumans, O.F., Ehlert, P.A.I., Regelink, I.C., Nelemans, J.A., Noij, I.G.A.M., van Tintelen, W., Rulkens, W.H., 2017. Chemical phosphorus recovery from animal manure and digestate. https://doi.org/10.18174/426297

Sommer, S.G., Petersen, S.O., Sørensen, P., Poulsen, H.D., Møller, H.B., 2007. Methane and carbon dioxide emissions and nitrogen turnover during liquid manure storage. Nutr. Cycl. Agroecosystems 78, 27-36. https://doi.org/10.1007/s10705-006-9072-4

Timmerman, M. 2016. Mestgassen uit melkveemest: Jaarrond metingen van $\mathrm{H}_{2} \mathrm{~S}$ concentraties. Wageningen WLR rapport 1002. http://dx.doi.org/10.18174/401764

Velthof, G.L., Hummelink, E., 2011. Ammoniak- en lachgasemissie na toediening van mineralenconcentraten. Alterra-rapport 2180

Vries de, J.W., P. Hoeksma, C.M. Groenestein. 2011. LevensCyclusAnalyse (LCA) Pilot Mineralenconcentraten. Wageningen Livestock Research Rapport 480.

https://edepot.wur.nl/177151 
Vries, J.W. de, Vinken, T.M.W.J., Hamelin, L., De Boer, I.J.M., 2012a. Comparing environmental consequences of anaerobic mono- and co-digestion of pig manure to produce bio-energy - A life cycle perspective. Bioresour. Technol. 125, 239-248. https://doi.org/10.1016/j.biortech.2012.08.124

Vries, J.W. de, Groenestein, C.M., De Boer, I.J.M., 2012b. Environmental consequences of processing manure to produce mineral fertilizer and bio-energy. J. Environ. Manage. 102, 173-183. https://doi.org/10.1016/j.jenvman.2012.02.032

Well, E. van, Keuskamp, J, Spijkerman, I., Monteny, G.J. 2021. Keldermetingen methaan- en Ammoniakconcentraties - Tussenrapportage. Rapportnummer: CLM-1046 


\section{Bijlage 1}

Bijlage 1 bevat extra tabellen van de samenstelling van de in- en uitgaande stromen en berekende scheidingsrendementen van scheidingsapparaten van de verwerkers in aanvulling op hoofdstuk 2 .

\section{Groot Zevert Vergisting - GENIAAL}

Tabel B1.1 Samenstelling van de in- en uitgaande stromen van de DAF-installatie van Groot Zevert Vergisting en het berekende scheidingsrendement als percentage van het influent van de DAF.

Gemiddelde van vijf bemonsteringen. ${ }^{1}$

\begin{tabular}{|c|c|c|c|c|c|c|c|c|}
\hline \multirow{3}{*}{ Parameter } & \multicolumn{4}{|c|}{ Samenstelling } & \multicolumn{3}{|c|}{ Scheidingsrendement ${ }^{6}$} & \multirow{3}{*}{ SOM } \\
\hline & Eenheid & Influent & Effluent & Slib $D A F^{4}$ & Eenheid ${ }^{5}$ & Dunne & Dikke & \\
\hline & & $\mathrm{DAF}^{2}$ & $\mathrm{DAF}^{3}$ & & & fractie & fractie & \\
\hline DS & $\left(\mathrm{g} \mathrm{kg}^{-1}\right)$ & 31 & & 30 & $\%$ & 94 & 6,3 & 100 \\
\hline os & $\left(\mathrm{g} \mathrm{kg}^{-1}\right)$ & 18 & & 18 & $\%$ & 94 & 6,4 & 100 \\
\hline $\mathrm{N}$ & $\left(\mathrm{g} \mathrm{kg}^{-1}\right)$ & 5,2 & & 5,1 & $\%$ & 94 & 6,4 & 100 \\
\hline $\mathrm{N}-\mathrm{NH}_{4}$ & $\left(\mathrm{~g} \mathrm{~kg}^{-1}\right)$ & 4,2 & & 4,1 & $\%$ & 94 & 6,2 & 100 \\
\hline $\mathrm{S}$ & $\left(\mathrm{g} \mathrm{kg}^{-1}\right)$ & 0,39 & & 0,38 & $\%$ & 94 & 6,2 & 100 \\
\hline $\mathrm{K}$ & $\left(\mathrm{g} \mathrm{kg}^{-1}\right)$ & 4,1 & & 4,1 & $\%$ & 94 & 6,2 & 100 \\
\hline $\mathrm{Ca}$ & $\left(\mathrm{g} \mathrm{kg}^{-1}\right)$ & 0,17 & & 0,16 & $\%$ & 94 & 6,0 & 100 \\
\hline $\mathrm{pH}$ & $(-)$ & 8,3 & & 8,3 & - & - & - & - \\
\hline
\end{tabular}

1 Massa: totale massa van processtroom per ton verwerkt digestaat uit de hoofdvergister, DS: droge stof, OS: organische stof, n.g.: niet geanalyseerd.

2 Dunne fractie van de tweede decanter centrifuge voor toevoeging antischuimmiddel (bemonsteringspunt G4).

3 Effluent van de DAF is niet bemonsterd.

4 Slib van de DAF (bemonsteringspunt G6).

5 Percentage t.o.v. de ingaande massa (inclusief toegevoegde chemie en bijbehorend oploswater).

6 Toevoeging van antischuimmiddel is niet meegenomen in de berekening, omdat de dit op massabasis verwaarloosbaar is (10 $\mathrm{ml}$ per $\mathrm{m}^{3}$ influent van de DAF). 


\section{Merensteyn}

Tabel B1.2 Samenstelling van de dikke fractie van de zeefbandpers van Merensteyn voor en na hygiënisatie. Gemiddelde van drie bemonsteringen. ${ }^{1}$

\begin{tabular}{llcc} 
Parameter & Eenheid & Dikke fractie voor hygienisatie & Dikke fractie na hygienisatie \\
Massa & $(\mathrm{kg})$ & 201 & 295 \\
\hline $\mathrm{DS}$ & $(\mathrm{g} / \mathrm{kg})$ & 286 & 226 \\
\hline $\mathrm{OS}$ & $(\mathrm{g} / \mathrm{kg})$ & 216 & 16 \\
\hline $\mathrm{P}_{2} \mathrm{O}_{5}$ & $(\mathrm{~g} / \mathrm{kg})$ & 16 & 13 \\
\hline $\mathrm{N}$ & $(\mathrm{g} / \mathrm{kg})$ & 13 & 5,2 \\
\hline $\mathrm{N}-\mathrm{NH}_{4}$ & $(\mathrm{~g} / \mathrm{kg})$ & 5,0 & 4,4 \\
\hline $\mathrm{S}$ & $(\mathrm{g} / \mathrm{kg})$ & 4,3 & 4,0 \\
\hline $\mathrm{K}$ & $(\mathrm{g} / \mathrm{kg})$ & 3,8 & 9,1 \\
\hline $\mathrm{Ca}$ & $(\mathrm{g} / \mathrm{kg})$ & 8,8 & 4,8 \\
\hline $\mathrm{Mg}$ & $(\mathrm{g} / \mathrm{kg})$ & 4,6 & 5,5 \\
\hline Fe & $(\mathrm{g} / \mathrm{kg})$ & 5,3 & 8,3 \\
\hline $\mathrm{pH}$ & $(-)$ & 8,3 & \\
\hline 1 & &
\end{tabular}

Tabel B1.3 Samenstelling van het effluent van de DAF-installatie en het influent en effluent van de twee papierfilters voor de eerste omgekeerde osmose-installatie van Merensteyn. Gemiddelde van drie bemonsteringen. ${ }^{1}$

\begin{tabular}{llccr} 
Parameter & Eenheid & Effluent DAF & & Influent papierfilters \\
Massa & $(\mathrm{kg})$ & 1011 & 1037 & 1037 \\
\hline $\mathrm{DS}$ & $(\mathrm{g} / \mathrm{kg})$ & 15 & 14 & 13 \\
$\mathrm{OS}$ & $(\mathrm{g} / \mathrm{kg})$ & 4,0 & 3,6 & 3,5 \\
\hline $\mathrm{P}_{2} \mathrm{O}_{5}$ & $(\mathrm{~g} / \mathrm{kg})$ & 0,050 & - & $<0,15$ \\
\hline $\mathrm{N}$ & $(\mathrm{g} / \mathrm{kg})$ & 2,9 & 2,6 & 2,7 \\
\hline $\mathrm{N}-\mathrm{NH}_{4}$ & $(\mathrm{~g} / \mathrm{kg})$ & 2,7 & 2,4 & 2,5 \\
\hline $\mathrm{S}$ & $(\mathrm{g} / \mathrm{kg})$ & 1,8 & 1,5 & 1,5 \\
\hline $\mathrm{K}$ & $(\mathrm{g} / \mathrm{kg})$ & 3,2 & 2,8 & 2,8 \\
\hline $\mathrm{Ca}$ & $(\mathrm{g} / \mathrm{kg})$ & 0,13 & 0,12 & 0,11 \\
\hline $\mathrm{Mg}$ & $(\mathrm{g} / \mathrm{kg})$ & 0,17 & 0,15 & 0,14 \\
\hline $\mathrm{Fe}$ & $(\mathrm{g} / \mathrm{kg})$ & 0,064 & 0,056 & 0,052
\end{tabular}

1 Massa: totale massa van processtroom per ton verwerkte mest, DS: droge stof, OS: organische stof, n.g.: niet geanalyseerd.

2 Effluent van de DAF voor opslagtank (bemonsteringspunt M7).

3 Berekend op basis van de verandering in de kaliumconcentratie door verdunning tussen bemonsteringspunt M7 en M8.

4 Effluent van het $2^{\mathrm{e}}$, in serie geschakelde, papierfilter (bemonsteringspunt M8). 


\section{Bijlage 2}

Deze memo bevat de resultaten van de chemische analyses van de membraandestillatieproef met het stikstof-kalium (NK)-concentraat van het bedrijf Kumac. Het CBLB, onderdeel van WUR, heeft de aan Jasper van Puffelen meegegeven monsters van de proef chemisch geanalyseerd. Via de gemeten concentraties is de behaalde indikkingsfactor op massabasis berekend. Van elke ingaande kg NKconcentraat kwam circa $18 \%$ terecht in het retentaat en circa $82 \%$ in het permeaat. Dat is berekend uit de verschillen in de kaliumconcentratie van de in- en uitgaande stromen. Het ingaande NKconcentraat werd door de membraandestillatie dus ongeveer 5,5 keer ingedikt. Praktisch $100 \%$ van de componenten $\mathrm{P}, \mathrm{K}, \mathrm{Mg}, \mathrm{Ca}, \mathrm{Fe}, \mathrm{Cu}, \mathrm{S}, \mathrm{Zn}$ en organische stof in het ingaande $\mathrm{NK}$-concentraat kwam terecht in het retentaat. Dit geldt niet voor $\mathrm{N}$ en $\mathrm{N}-\mathrm{NH}_{4}$. Van de $\mathrm{N}-\mathrm{NH}_{4}$ in het ingaande $\mathrm{NK}$-concentraat eindigde circa $48 \%$ in het retentaat en circa $51 \%$ in het permeaat. De stikstof in het ingaande NKconcentraat bestond voor $93 \%$ uit $\mathrm{N}-\mathrm{NH}_{4}$. Uit het retentaat zijn zoutkristallen gezeefd (zie onderstaande foto).

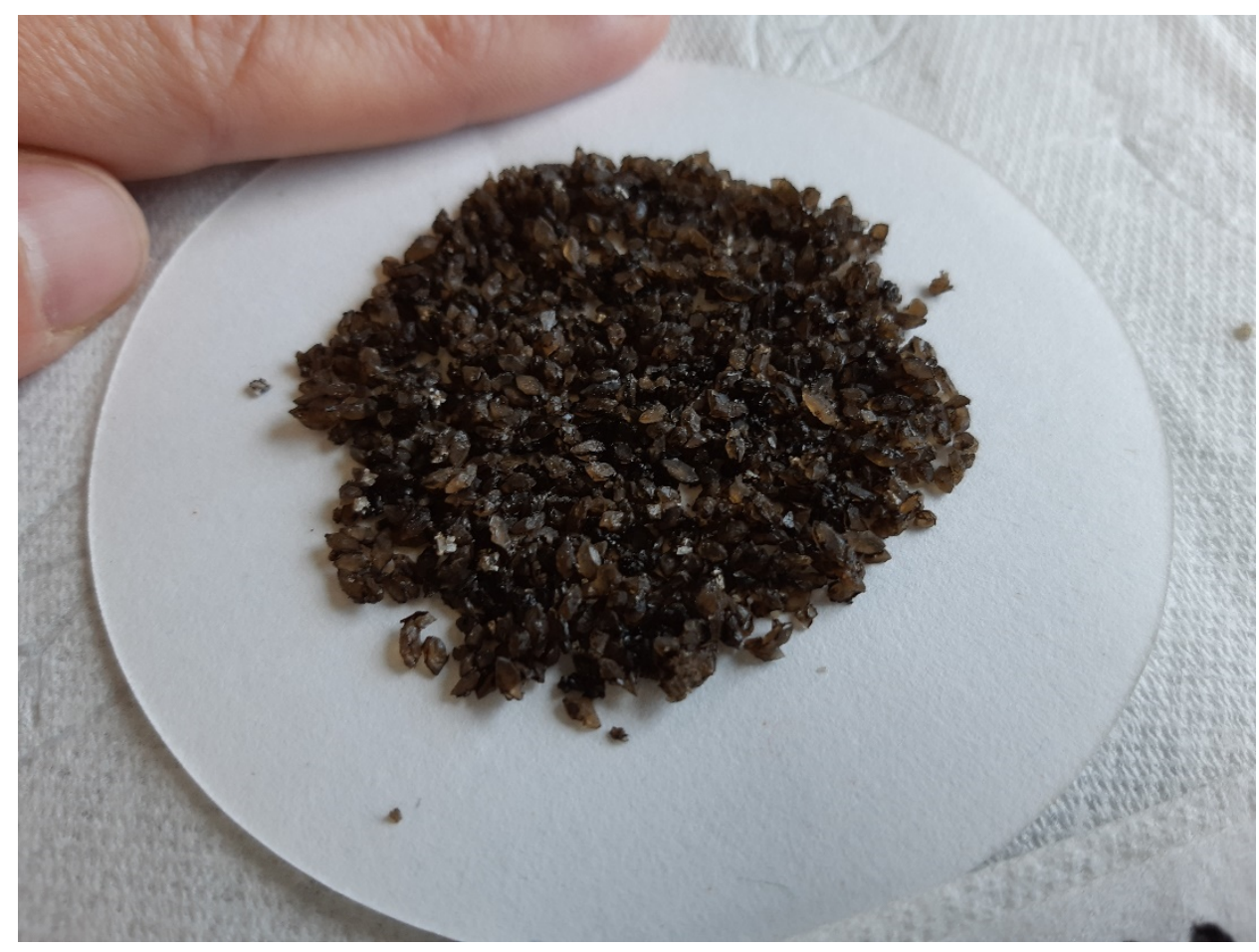


Samenstelling van het ingaande NK-concentraat, het retentaat voor en na afzeven van de zoutkristallen en het permeaat van de membraandestillatie.

\begin{tabular}{|c|c|c|c|c|c|}
\hline Parameter & Eenheid & $\begin{array}{l}\text { Ingaand NK- } \\
\text { concentraat }\end{array}$ & $\begin{array}{l}\text { Retentaat inclusief } \\
\text { zoutkristallen }\end{array}$ & $\begin{array}{l}\text { Retentaat na } \\
\text { afzeven } \\
\text { zoutkristallen }\end{array}$ & Permeaat \\
\hline Organische stof & $\% \mathrm{~m} / \mathrm{m}$ & 0,83 & c & 4,86 & $<0,10$ \\
\hline $\mathrm{N}$ & $\% \mathrm{~m} / \mathrm{m}$ & 0,71 & c & 2,10 & 0,42 \\
\hline $\mathrm{Pa}^{\mathrm{a}}$ & $\% \mathrm{~m} / \mathrm{m}$ & $<0,0044$ & 0,010 & 0,010 & $<0,0083$ \\
\hline $\mathrm{K}^{\mathrm{b}}$ & $\% \mathrm{~m} / \mathrm{m}$ & 0,80 & 4,4 & 3,9 & $<0,060$ \\
\hline $\mathrm{Mg}$ & $\% \mathrm{~m} / \mathrm{m}$ & 0,02 & 0,13 & 0,12 & $<0,00071$ \\
\hline $\mathrm{Ca}$ & $\% \mathrm{~m} / \mathrm{m}$ & 0,01 & 0,018 & 0,018 & $<0,00071$ \\
\hline $\mathrm{Fe}$ & $\% \mathrm{~m} / \mathrm{m}$ & 0,007 & 0,028 & 0,028 & $<0,001$ \\
\hline $\mathrm{Zn}$ & $\% \mathrm{~m} / \mathrm{m}$ & $<0,0005$ & 0,00075 & 0,00075 & $<0,0005$ \\
\hline $\begin{array}{l}\mathrm{pH} \text { (in een } \mathrm{CaCl}_{2}- \\
\text { oplossing) }\end{array}$ & - & 8,1 & c & 8,7 & 9 \\
\hline $\mathrm{C} / \mathrm{N}$-verhouding & - & 1 & c & 1 & c \\
\hline Dichtheid & $\mathrm{kg} / \mathrm{l}$ & 1,013 & c & 1,15 & 0,993 \\
\hline
\end{tabular}

Zeven van verschillende maaswijdtes zijn gebruikt om de zoutkristallen in het retentaat af te scheiden. De natte zoutkristallen zijn daarna 22 uur bij $40^{\circ} \mathrm{C}$ gedroogd. Per kg retentaat is circa $15 \mathrm{~g}$ aan gedroogde zoutkristallen geoogst.

Massa afgezeefde zoutkristallen voor de verschillende maaswijdtes per $\mathrm{kg}$ retentaat van de membraandestillatie.

\begin{tabular}{clc} 
& Maaswijdte zeef $(\mathrm{mm})$ & Gedroogde massa per kg retentaat $(\mathrm{g})$ \\
2,0 & 1,5 \\
\hline 1,4 & 5,6 \\
\hline 0,6 & 4,8 \\
\hline Totaal & 0,425 & 3,3 \\
\hline
\end{tabular}

Een deel van de gedroogde zoutkristallen is na oplossing ervan chemisch geanalyseerd. De resultaten daarvan zijn omgerekend naar de gedroogde samenstelling. 
Samenstelling van de gedroogde zoutkristallen uit het retentaat van de membraandestillatie.

\begin{tabular}{lc} 
Parameter & Percentage van totale gedroogde massa \\
$\mathrm{N}-\mathrm{NH}_{4}$ & 1,8 \\
\hline $\mathrm{P}$ & 0,0059 \\
\hline $\mathrm{K}$ & 36 \\
$\mathrm{Mg}$ & 1,0 \\
\hline $\mathrm{Ca}$ & 0,025 \\
\hline $\mathrm{Fe}$ & 0,018 \\
$\mathrm{Cu}$ & 0,0020 \\
\hline $\mathrm{S}$ & 16 \\
\hline $\mathrm{Al}$ & 0,0010 \\
\hline $\mathrm{Mn}$ & 0,0003 \\
\hline $\mathrm{Na}$ & 1,0 \\
\hline Total & 56
\end{tabular}

De componenten die in de chemische analyse van de zoutkristallen zijn meegenomen, verklaren circa $56 \%$ van de totale massa van de gedroogde zoutkristallen. Analyse van de gedroogde zoutkristallen met $x$-ray diffraction (XRD) laat zien dat de zwavel die het bevat aanwezig is in de vorm van sulfaten $\left(\mathrm{K}_{2} \mathrm{SO}_{4}, \mathrm{KSO}_{3}\right.$ en $\left.\mathrm{K}_{3} \mathrm{Na}\left(\mathrm{SO}_{4}\right)_{2}\right)$. Het is daarom waarschijnlijk dat een groot deel van de nog niet verklaarde massa van de gedroogde zoutkristallen bestaat uit de zuurstofatomen in deze sulfaten. Als wordt aangenomen dat alle zwavel aanwezig is als sulfaat, dan verklaart dat circa $32 \%$ extra van de zoutkristalmassa bovenop de al verklaarde $56 \%$.

Percentage van de componenten in het ingaande NK-concentraat dat terechtkomt in het retentaat, de afgezeefde zoutkristallen en het permeaat van de membraandestillatie.

\begin{tabular}{|c|c|c|c|}
\hline Parameter & $\begin{array}{l}\text { Retentaat (inclusief } \\
\text { zoutkristallen) }\end{array}$ & Zoutkristallen (afgezeefd) & Permeaat \\
\hline Totale massa & 18 & 0,015 & 82 \\
\hline$P$ & 100 & a & a \\
\hline $\mathrm{K}$ & 100 & 12,7 & a \\
\hline $\mathrm{Ca}$ & 100 & 0,9 & a \\
\hline $\mathrm{Fe}$ & 100 & 0,7 & a \\
\hline $\mathrm{Cu}$ & 100 & a & a \\
\hline$S$ & 100 & 10,9 & a \\
\hline
\end{tabular}

a kan niet berekend worden vanwege één of meerdere gemeten concentraties onder de kwantificeringslimiet (LOQ).

Het ingaande $\mathrm{NK}$-concentraat had op massabasis een verhouding $\mathrm{N}-\mathrm{NH}_{4} / \mathrm{K}$ van $0,83\left(\mathrm{~N}-\mathrm{NH}_{4} / \mathrm{K}_{2} \mathrm{O}\right.$ is $0,69)$. Ongeveer $13 \%$ van de kalium uit het ingaande $\mathrm{NK}$-concentraat werd door afzeven van zoutkristallen uit het retentaat verwijderd. Dit afzeven geeft een (te) kleine verbetering van de N/Kverhouding op massabasis (berekend als $\mathrm{N}-\mathrm{NH}_{4} / \mathrm{K}$ ) van 0,44 in het retentaat inclusief zoutkristallen naar 0,39 in het retentaat zonder zoutkristallen. Voor $\mathrm{N}-\mathrm{NH}_{4} / \mathrm{K}_{2} \mathrm{O}$ is deze verhoudingsafname van 0,37 naar 0,33 . De aanzienlijk lagere verhouding $\mathrm{N}-\mathrm{NH}_{4} / \mathrm{K}$ in het retentaat ten opzichte van het ingaande NK-concentraat is het resultaat van meeliften van gasvormig ammoniak door het membraan.

Circa $51 \%$ van de $\mathrm{N}-\mathrm{NH}_{4}$ lift met de waterdamp mee door het membraan. Membraandestillatie kan daardoor stikstof verwijderen en dat leidt tot een ongeveer twee keer lagere N/K-verhouding in het retentaat ten opzichte van het ingaande NK-concentraat. Dit resulteert echter in een ammoniakwater (permeaat) met een $\mathrm{pH}$ van 9. Wil je het meeliften van ammoniak en de hoge $\mathrm{pH}$ van het permeaat voorkomen, dan zal de $\mathrm{pH}$ van het $\mathrm{NK}$-concentraat verlaagd moeten worden tot naar verwachting onder de 7 (afhankelijk van de temperatuur), zodat praktisch alle $\mathrm{N}-\mathrm{NH}_{4}$ aanwezig is als ammonium in plaats van (deels) als ammoniak. Dat kost echter veel (zwavel)zuur vanwege de bufferende werking 
van NK-concentraat door de aanwezigheid van o.a. bicarbonaten. Toevoeging van een zuur, specifiek ook zwavelzuur, beïnvloedt mogelijk de hoeveelheid kalium die als zoutkristallen neerslaat.

Afzeven van de zoutkristallen levert op basis van de in deze proef gebruikte procescondities nog geen perspectief om de N/K-verhouding van het geproduceerde retentaat aanzienlijk te verhogen. RN Solutions geeft aan dat een hogere indikking dan in deze proef is behaald mogelijk is met membraandestillatie. Onderzocht moet worden of een hogere indikking ook leidt tot het verwachte hogere percentage van ingaand kalium, dat dan als zoutkristal wordt afgescheiden. Ook zou onderzocht kunnen worden of er voor dit proces geschikte membranen zijn die ammoniak (deels) tegenhouden, maar waterdamp wel doorlaten.

Een aandachtspunt is dat het NK-concentraat van Kumac een twee tot drie keer hoger zwavelgehalte heeft dan het NK-concentraat van Maatschap Van Amstel. De hoeveelheid uit het NK-concentraat van Maatschap Van Amstel af te scheiden kalium, als zoutkristallen, is daarom bij gelijke procescondities mogelijk kleiner.

Kortom, membraandestillatie kan een hoge indikking van NK-concentraat behalen, waarbij echter wel zuurtoevoeging nodig is om te voorkomen dat $\mathrm{N}-\mathrm{NH}_{4}$ het membraan passeert. Door het indikken slaan kaliumzouten neer waarbij kristallen worden gevormd die groot genoeg zijn om met een zeef af te scheiden. De techniek biedt daarmee perspectief voor het scheiden van stikstof en kalium indien het percentage als zoutkristallen afgevangen kalium kan worden verhoogd. 


\section{Bijlage 3}

\section{Verkennend onderzoek naar emissie van $\mathrm{N}_{2} \mathrm{O}$ en $\mathrm{H}_{2} \mathrm{~S}$ bij opslag van de mengsels van mineralenconcentraat met nitraat- of sulfaathoudende bemestingsproducten}

Phillip Ehlert, Willeke van Tintelen, Peter Nobels en Jordy van 't Hull

\section{B3.1 Inleiding}

De samenstelling van een mineralenconcentraat is afhankelijk van het soort mest waaruit het geproduceerd is (varkensdrijfmest, runderdrijfmest of co-vergiste mest (digestaat)) en de procesgang. In de regel vraagt de verhouding tussen stikstof, kalium en zwavel van een mineralenconcentraat bijsturing om te kunnen beantwoorden aan de vraag van het gewas (gewasbehoefte) gegeven de bodemvruchtbaarheidstoestand van het landbouwperceel. Dit is door het bedrijf Groot Zevert Vergisting (GZV) uitgewerkt in het concept van de Groene Weide Meststof (GWM). De samenstelling van de GWM werd in eerste instantie afgestemd op de gewasbehoefte van gras en is nadien ook uitgewerkt voor snijmais.

Gras vraagt voor de eerste twee sneden extra zwavel. Voor de eerste twee sneden wordt daarom herwonnen ammoniumsulfaatoplossing (AS) ${ }^{28}$ aan het mineralenconcentraat van GZV toegevoegd. Hierdoor wordt de verhouding stikstof en zwavel (N/S-ratio) aangepast (d.w.z. verlaagd). Voor volgende sneden is een hogere N/S-ratio nodig die verkregen wordt door ureum of Urean toe te voegen. Urean is een vloeibare meststof gebaseerd op ureum en ammoniumnitraat. Het aandeel herwonnen stikstof in de GWM is altijd hoger dan 75\%. Toevoegen van AS of Urean leidt tot menging van mineralenconcentraat met sulfaat of nitraat. In een anaeroob milieu kunnen door microbiologische processen sulfaat of nitraat worden gereduceerd, waardoor respectievelijk waterstofsulfide $\left(\mathrm{H}_{2} \mathrm{~S}\right)$ of lachgas $\left(\mathrm{N}_{2} \mathrm{O}\right)$ ontstaat. Vorming van $\mathrm{H}_{2} \mathrm{~S}$ levert een risico, omdat het een zeer giftig gas is (zie paragraaf 5.2.4 van dit rapport). Omzetting van nitraatstikstof naar lachgas $\left(\mathrm{N}_{2} \mathrm{O}\right)$ of stikstof $\left(\mathrm{N}_{2}\right)$ verlaagt het aandeel effectief werkende stikstof voor het gewas. Microbiologische processen zijn verantwoordelijk voor de vorming van deze gassen. De risico's zijn beheersbaar als menging van de meststoffen vlak voor het uitrijden (bemesten) plaatsvindt: de microbiologische processen hebben dan nog weinig effect kunnen uitoefenen. Opslag van de GWM vormt een aandachtspunt, omdat de microbiologische processen dan wel effect kunnen uitoefenen vanwege de duur van de opslag. Het risico op vorming van $\mathrm{H}_{2} \mathrm{~S}$ en $\mathrm{N}_{2} \mathrm{O}$ in mengsels van mineralenconcentraat en $\mathrm{AS}$ of ammoniumnitraatoplossing (AN) is onderzocht in twee verkennende deelstudies.

\section{Doelen van de deelstudies:}

I. Vaststellen of menging van AN met mineralenconcentraat leidt tot een verhoogd risico op de vorming van $\mathrm{N}_{2} \mathrm{O}$ bij opslag.

II. Vaststellen of menging van AS met mineralenconcentraat leidt tot een verhoogd risico op de vorming van $\mathrm{H}_{2} \mathrm{~S}$ bij opslag.

\section{B3.2 Aanpak en opzet}

Het onderzoek naar risico's op vorming van $\mathrm{N}_{2} \mathrm{O}$ of $\mathrm{H}_{2} \mathrm{~S}$ is uitgevoerd via twee incubatiestudies met mengsels van mineralenconcentraat met respectievelijk AN of AS. De incubatiestudie voor het mengsel van mineralenconcentraat met AS is op twee verschillende manieren uitgevoerd (zie verderop in paragraaf 2.2).

\footnotetext{
${ }^{28}$ Geproduceerd door een chemische luchtwasser voor de luchtzuivering van lucht van een bedrijfshal voor compostering van zuiveringsslib (GMB Zutphen).
} 


\section{B3.2.1 Incubatiestudie naar lachgasemissie}

\section{B3.2.1.1 Opzet}

Een incubatieproef is uitgevoerd met mineralenconcentraat waaraan AN wordt toegevoegd. De emissie van $\mathrm{N}_{2} \mathrm{O}$ in de tijd werd gemeten met een akoestische gasmonitor. Als controlegroep is ook mineralenconcentraat zonder toegevoegd AN meegenomen in de proef.

Tabel B3.1 Ontwerp van de incubatieproef

Behandelingen

Ammoniumnitraatoplossing (AN) als volumepercentage in het mengsel

met mineralenconcentraat

Incubatieduur (in dagen na toevoeging van AN)
Aantal fluxpotten 2

\begin{tabular}{l|l}
\hline Geen AN & 2 \\
\hline $4 \%$ AN & 2 \\
\hline $8 \%$ AN & 2 \\
\hline $1 / 2,1,2,4,7,8,11,14,21$, & \\
22,23 en 28 & \\
\hline
\end{tabular}

\section{B3.2.1.2 Gebruikte bemestingsproducten}

AN met een concentratie van $150 \mathrm{~g} \mathrm{~N} / \mathrm{L}$ is gemaakt door 428,8 $\mathrm{g} \mathrm{NH}_{4} \mathrm{NO}_{3}$ (anhydride) in $1 \mathrm{~L}$ demiwater op te lossen. Met die oplossing zijn de mengsels van mineralenconcentraat met AN gemaakt.

Het mengsel van $4 \%$ AN bestaat op volumebasis uit $96 \%$ mineralenconcentraat en $4 \%$ AN. Het mengsel van $8 \%$ AN bestaat op volumebasis uit $92 \%$ mineralenconcentraat en $8 \%$ AN.

Ten tijde van uitvoering van deze incubatiestudie was de omgekeerde osmose-installatie van GZV niet in bedrijf. De incubatiestudie is daarom uitgevoerd met mineralenconcentraat van het bedrijf Agro America. De samenstelling hiervan is gegeven in Tabel B3.2. 


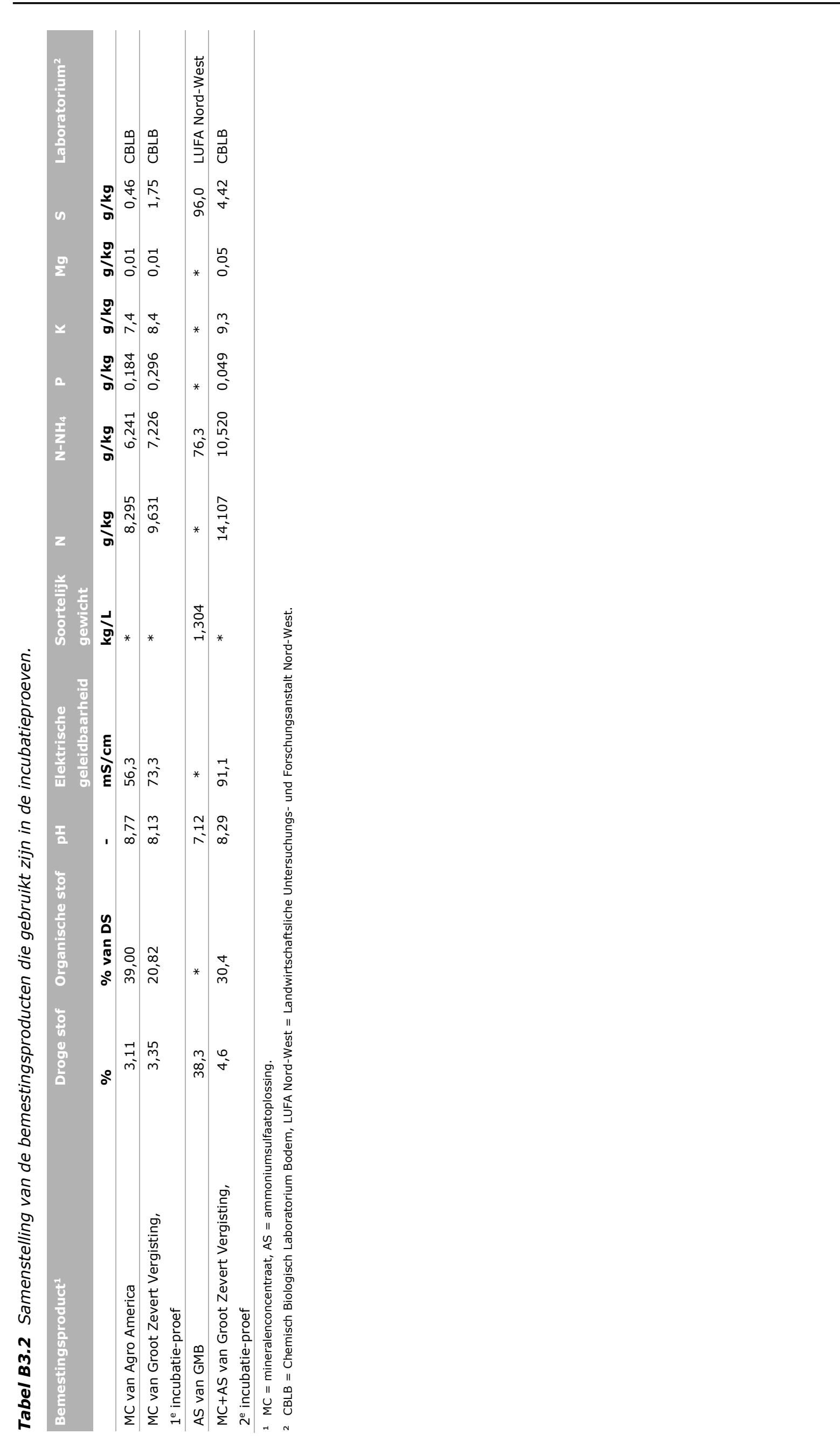

162 | Wageningen Environmental Research Rapport 3120 


\section{B3.2.1.3 Incubatie}

De mengsels $\left(500 \mathrm{ml}\right.$ ) werden in glazen fluxpotten bij $15^{\circ} \mathrm{C}$ geïncubeerd. Op 1/2, 1, 2, 4, 7, 8, 11, 14, 21, 22, 23 en 28 dagen na toediening van AN werd het gehalte aan $\mathrm{N}_{2} \mathrm{O}$ in de headspace met de akoestische gasmonitor (INNOVA 1312, LumaSense Technologies) gemeten. Uit die metingen werden vervolgens de $\mathrm{N}_{2} \mathrm{O}$-emissiefluxen per fluxpot afgeleid (Afbeelding B3.1).

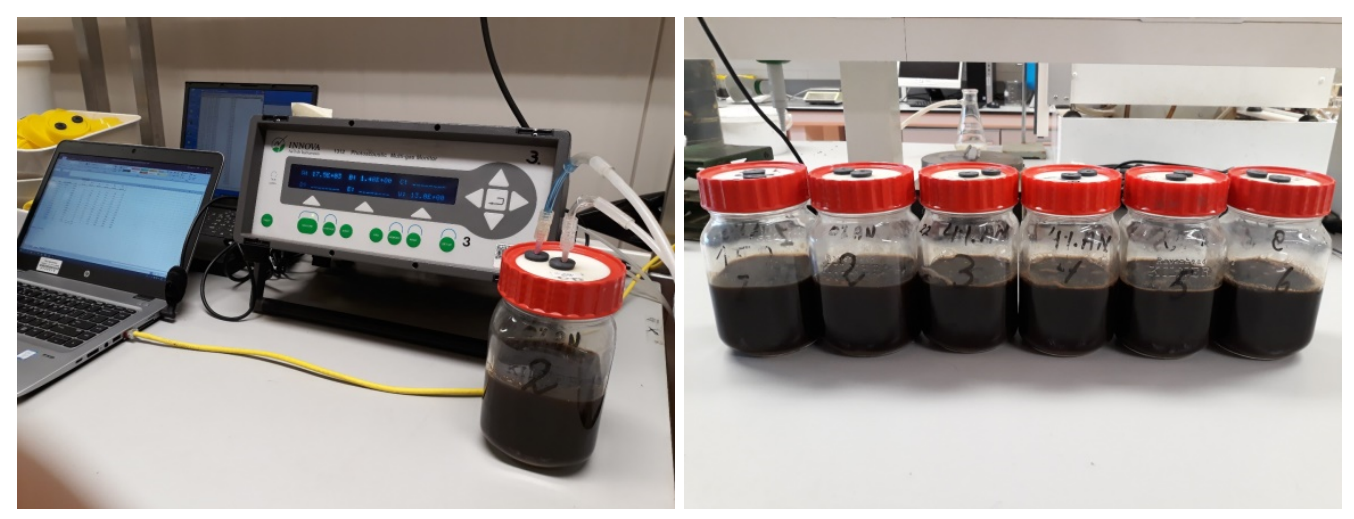

Afbeelding B3.1 Links: opstelling van de akoestische gasmonitor met een fluxpot. Rechts: de zes gebruikte fluxpotten met daarover verdeeld de drie verschillende behandelingen.

\section{B3.2.1.4 Berekeningen}

De in de incubatiestudies opgetreden emissieflux tussen twee meetmomenten is berekend in $\mu \mathrm{l} \mathrm{N}_{2} \mathrm{O}-\mathrm{N}$ per uur.

Daarbij is de gemeten $\mathrm{N}_{2} \mathrm{O}$-concentratie gecorrigeerd voor het interne volume van de gasmonitor:

[(volume headspace + interne volume) $* \mathrm{~N}_{2} \mathrm{O}$-concentratie - (intern volume $* \mathrm{~N}_{2} \mathrm{O}$-concentratie vorige meting)] / (volume headspace + interne volume).

Daarbij is het volume in liters en de $\mathrm{N}_{2} \mathrm{O}$-concentratie in ppm gehanteerd.

De emissieflux per fluxpot is daarna als volgt berekend:

1. (gecorrigeerde $\mathrm{N}_{2} \mathrm{O}$-concentratie) - $\left(\mathrm{N}_{2} \mathrm{O}\right.$-concentratie buitenlucht $)=\mathrm{ml} \mathrm{N} \mathrm{N}_{2} \mathrm{O}$ per liter headspace

2. vermenigvuldigen met het totaal van het volume van de headspace en het interne volume (in liter) $=\mathrm{ml} \mathrm{N} 2 \mathrm{O}$

3. delen door de incubatieduur (in uren) en het vloeistofoppervlak (in $\mathrm{m}^{2}$ ) $=\mathrm{ml} \mathrm{N}_{2} \mathrm{O}$ per $\mathrm{m}^{2}$ per uur

4. delen door het molaire volume $(22,4 \mathrm{liter} / \mathrm{mol})=\mathrm{mmol} \mathrm{N}_{2} \mathrm{O}$ per $\mathrm{m}^{2}$ per uur; het molaire volume is afhankelijk van de temperatuur. De temperatuur in de meetcel is constant; die van de fluxpot niet. $\mathrm{Er}$ is uitgegaan van een vaste waarde van $22,4 \mathrm{~mol} / \mathrm{liter}$.

5. vermenigvuldigen met $28\left(\mathrm{~g} \mathrm{~N} / \mathrm{mol} \mathrm{N}_{2} \mathrm{O}\right)=\mathrm{mg} \mathrm{N}_{2} \mathrm{O}-\mathrm{N}$ per $\mathrm{m}^{2}$ per uur.

\section{B3.2.2 Incubatiestudie naar emissie van waterstofsulfide}

\section{B3.2.2.1 Opzet}

De opzet was gebaseerd op het meten van $\mathrm{H}_{2} \mathrm{~S}$ door middel van precipitatie als zinksulfide ( $\mathrm{ZnS}$ ) in een zinkacetaatoplossing ( $\mathrm{ZnAc}$ ) conform de methode van Eriksen et al (2012). ${ }^{29}$ Emissie van $\mathrm{H}_{2} \mathrm{~S}$ leidt tot verhoging van de concentratie van $\mathrm{H}_{2} \mathrm{~S}$ in de gasfase. Door $\mathrm{H}_{2} \mathrm{~S}$ in contact te brengen met $\mathrm{ZnAc}$ slaat $\mathrm{S}$ neer als ZnS en kan de emissie gemeten worden door de hoeveelheid gevormd sulfide te bepalen (Eriksen et al., 2012). Als controlegroep is ook mineralenconcentraat zonder toevoeging van AS meegenomen. Er zijn twee incubatieproeven uitgevoerd.

De eerste incubatieproef is uitgevoerd met mineralenconcentraat van GZV waaraan AS werd toegevoegd. De vorming van $\mathrm{H}_{2} \mathrm{~S}$ in de tijd werd op twee manieren gemeten. De eerste manier was

\footnotetext{
${ }^{29}$ Eriksen, J., A.J. Andersen, H.V. Poulsen, A.P.S. Ademsen \& S.O. Petersen, 2012. Sulfur turnover and emissions during storage of cattle slurry: effects of acidification and sulfur addition. J. Environ. Qual. 41: 1633 - 1666. Doi: $10.2134 /$ jeq2012.0012
} 
het vanaf het begin mee incuberen van een cilinder met $50 \mathrm{ml} \mathrm{ZnAc} \mathrm{in} \mathrm{de} \mathrm{fluxpot.} \mathrm{Dit} \mathrm{is} \mathrm{een} \mathrm{meting}$ van het potentiële risico op emissie van $\mathrm{H}_{2} \mathrm{~S}$. De tweede manier was om op het gewenste bemonsteringstijdstip ZnAc aan een al aanwezige lege cilinder in de fluxpot toe te voegen aan de ZnAc-oplossing, het geheel een nacht te laten staan en daarna een monster te nemen. Dit is een meting van het actuele risico op emissie van $\mathrm{H}_{2} \mathrm{~S}$. Toevoeging van de $\mathrm{ZnAc}$ gebeurde met een injectiespuit door het septa in de deksels van de fluxpotten. Beide manieren werden als verschillende behandelingen in elke proef meegenomen. Tabel B3.3 geeft het ontwerp van de eerste incubatieproef naar emissie van waterstofsulfide.

Tabel B3.3 Ontwerp van de eerste incubatieproef voor de vaststelling van emissie van waterstofsulfide

\begin{tabular}{|c|c|c|c|c|}
\hline \multicolumn{2}{|c|}{ Behandelingen ${ }^{1}$} & \multirow[t]{2}{*}{ Aantal objecten } & \multirow{2}{*}{$\begin{array}{l}\text { Factor voor het } \\
\text { aantal combinaties }\end{array}$} & \multirow[t]{2}{*}{ Aantal fluxpotten } \\
\hline AS & ZnAc & & & \\
\hline geen & toegevoegd vanaf begin & 1 & \multirow{3}{*}{4} & \\
\hline met & toegevoegd vanaf begin & 1 & & \\
\hline met & toegevoegd op bemonsteringstijdstip & 1 & & \\
\hline Incubatieduur & $1,8,15,29,50$ dagen bij $15^{\circ} \mathrm{C}$ & 1 & 5 & \\
\hline Herhalingen & & & 2 & \\
\hline
\end{tabular}

${ }^{1} \mathrm{AS}=$ ammoniumsulfaatoplossing, $\mathrm{ZnAC}=$ zinkacetaatoplossing

Direct na het inzetten van de eerste incubatieproef ontstond in de fluxpotten waar vanaf het begin ZnAc in zat een witte neerslag die nauwelijks qua hoeveelheid toenam in de tijd. Precipitatie van $\mathrm{ZnS}$ in de ZnAc werd niet visueel waargenomen en ZnS werd ook niet gemeten. De neerslag wordt daarom toegeschreven aan de vorming van zinkcarbonaten. Om een te lage buffercapaciteit van de $Z n A c$ uit te sluiten, werd een deel van de incubatieproef herhaald met een groter volume van $300 \mathrm{ml} \mathrm{ZnAc} \mathrm{(zie}$ afbeelding C2). Tabel B3.4 geeft het ontwerp van deze tweede incubatieproef.

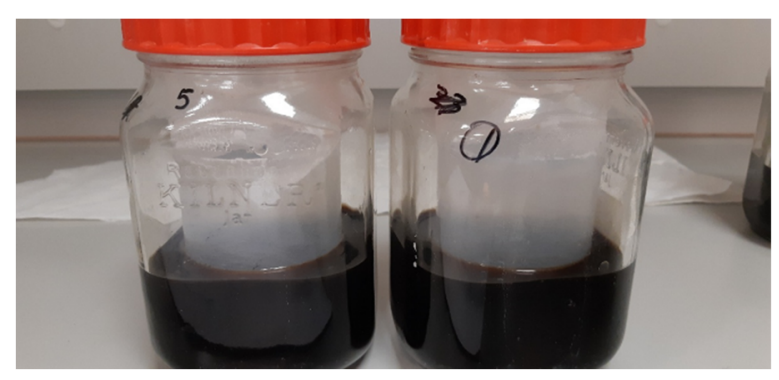

Afbeelding B3.2 Tweede incubatieproef met $300 \mathrm{ml}$ mengsel van mineralenconcentraat en ammoniumsulfaatoplossing en $300 \mathrm{ml}$ zinkacetaatoplossing.

Tabel B3.4 Ontwerp van de tweede incubatieproef voor de vaststelling van emissie van waterstofsulfide

\begin{tabular}{|c|c|c|c|}
\hline \multicolumn{2}{|c|}{ Behandelingen ${ }^{1}$} & Aantal objecten & Aantal fluxpotten \\
\hline geen & toegevoegd vanaf begin & 1 & \\
\hline Incubatieduur & 20,40 dagen bij $15^{\circ} \mathrm{C}$ & 2 & \\
\hline Totaal & & & 8 \\
\hline
\end{tabular}

1 AS = ammoniumsulfaatoplossing, $\mathrm{ZnAC}=$ zinkacetaatoplossing 


\section{B3.2.2.2 Gebruikte bemestingsproducten}

De eerder getoonde bemestingsproducten (Tabel B3.2) zijn gebruikt voor het maken van de mengsels. Het mengsel van mineralenconcentraat en AS bestond op volumebasis uit $97 \%$ mineralenconcentraat en $3 \%$ AS. Het gebruikte mineralenconcentraat is afkomstig van GZV, het gebruikte AS is afkomstig van het bedrijf GMB uit Zutphen.

\section{B3.2.2.3 Incubatie}

Het oogmerk van de incubatiestudie was gasvormig waterstofsulfide op te vangen in ZnAc. De incubatie werd uitgevoerd in fluxpotten met een septum in het deksel. Bij de eerste incubatieproef werd voorafgaand in elke fluxpot een bekerglaasje met ZnAc of een leeg bekerglaasje opgehangen. Bij de behandelingen met lege bekerglaasjes werd op het gewenste tijdstip met een injectiespuit via het septum ZnAc toegevoegd aan het opgehangen bekerglaasje. Bij de tweede incubatieproef werd een bekerglas (hard plastic) met ZnAc in het mengsel geplaatst. Aan het in de tweede incubatieproef gebruikte ZnAc werd voorafgaand een zeep (Trion-X-100) toegevoegd om gevormde neerslagen tijdens de chemische analyse beter gesuspendeerd te houden. Dit omdat de ervaring bij de eerste incubatieproef was dat de neerslag zich in vrij grote brokstukken vormde (zie paragraaf 2.2.4).

Om de ZnAc te maken, werd $200 \mathrm{~g}$ zinkacetaatdihydraat opgelost in $1 \mathrm{~L}$ zuurstofarm demiwater. Deze stockoplossing werd in het donker gekoeld $\left(4^{\circ} \mathrm{C}\right)$ bewaard in een zuurstofwerende glazen fles.

Voorafgaand aan de incubatie werd $\mathrm{N}_{2}$ door het mineralenconcentraat geleid om de $\mathrm{CO}_{2}$ die het bevat zo veel mogelijk te verwijderen.

De contacttijd met lucht bij bemonstering van de ZnAc in de fluxpotten op de verschillende tijdstippen werd geminimaliseerd om absorptie van zuurstof zo veel mogelijk te voorkomen.

In beide incubatieproeven werd geïncubeerd bij $15^{\circ} \mathrm{C}$ in een van licht afgesloten incubatorkast. Bij de eerste incubatieproef werd op vijf tijdstippen bemonsterd, bij de tweede incubatieproef werd op twee tijdstippen bemonsterd.

\section{B3.2.2.4 Chemische analyses}

Aanvankelijk is geprobeerd de gesuspendeerde deeltjes ZnS via ICP-OES te meten. Daartoe werd een aparte verstuiver ( $\mathrm{V}$-groove verstuiver) gebruikt om te zorgen dat de gevormde suspensie goed verneveld werd. Bij een gewoonlijk gebruikt verstuivertype zou de verstuiver door de deeltjes van de suspensie verstopt raken. De grootte van de gevormde deeltjes varieerde nogal waardoor de gevormde suspensies niet goed homogeen te krijgen waren, een goede meting was hierdoor niet mogelijk. Daarop is besloten om geprecipiteerde zwavelverbindingen titrimetrisch te bepalen met de methyleenblauwmethode. Bij de tweede incubatieproef waren de deeltjes zinksulfide klein genoeg en bleef, door het toevoegen van Triton-X-100, de suspensie lang genoeg homogeen om via ICP-OES geanalyseerd te kunnen worden. Al deze chemische analyses zijn uitgevoerd door het Chemisch Biologisch Laboratorium Bodem (CBLB), onderdeel van WUR.

\section{B3.3 Resultaten}

\section{B3.3.1 Emissie van lachgas}

Figuur B3.1 toont de gemeten $\mathrm{N}_{2} \mathrm{O}$-concentraties in de headspace van de fluxpotten voor de verschillende behandelingen in de tijd. De gemeten $\mathrm{N}_{2} \mathrm{O}$-concentratie voor de controlegroep, zonder toegevoegd AN, was over de gehele incubatieduur verwaarloosbaar klein. Een lichte verhoging in de $\mathrm{N}_{2} \mathrm{O}$-concentratie, te klein om te zien in Figuur B3.1, werd voor de behandelingen met toegevoegd AN bij een incubatieduur van vier dagen gemeten. Pas tussen 14 en 21 dagen na toevoeging van AN namen de concentraties voor de behandelingen van $4 \%$ en $8 \%$ AN fors toe. De toename begon eerder bij de $4 \%$ AN-behandeling dan bij de $8 \%$ AN-behandeling. Bij de $4 \%$ behandeling nam de concentratie 35 dagen na toevoeging van AN weer af; bij de $8 \%$ behandeling nam de concentratie 42 dagen na toevoeging weer af. De $\mathrm{N}_{2} \mathrm{O}$-emissie bij de $4 \%$ AN-behandeling begon dus eerder dan bij de $8 \%$ ANbehandeling en stopte ook eerder. 


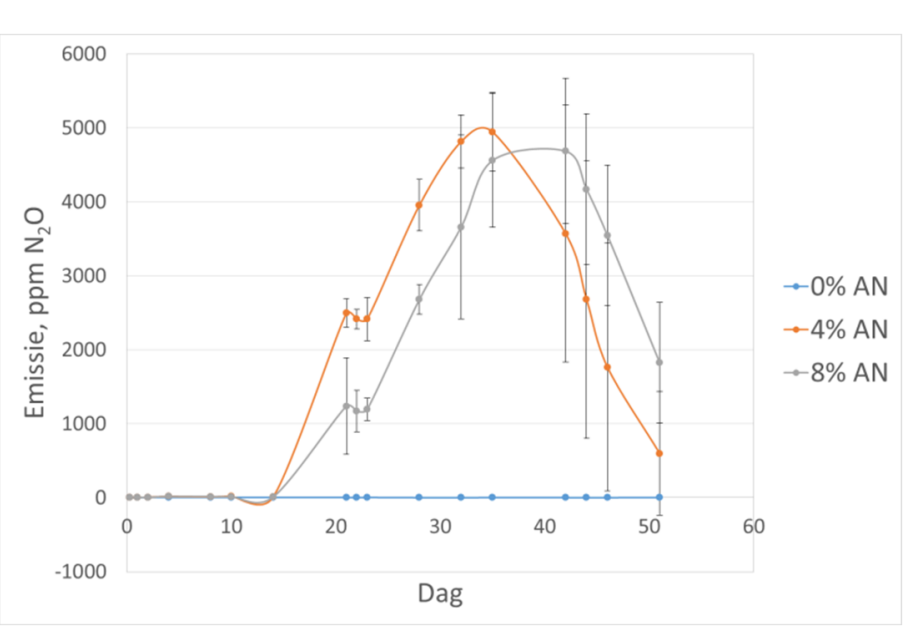

Figuur B3.1 Gemiddelde lachgasconcentratie in de tijd in de headspace van de afgesloten fluxpotten met mengsels van mineralenconcentraat met op volumebasis $0 \%, 4 \%$ of $8 \%$ van $150 \mathrm{~g} \mathrm{~N} / \mathrm{L}$ ammoniumnitraatoplossing (AN) voor incubatie bij $15^{\circ} \mathrm{C}$. Foutenbalken tonen de standaardafwijking gebaseerd op twee herhalingen.

De $\mathrm{N}_{2} \mathrm{O}$-emissieflux van de vloeistof naar de headspace van de fluxpotten is berekend uit de verandering in de $\mathrm{N}_{2} \mathrm{O}$-concentraties in de headspace tussen twee opeenvolgende bemonsteringen in combinatie met het volume van de headspace. Waargenomen is dat de septa van de fluxpotten niet bol stonden, daaruit wordt geconcludeerd dat de druk in de headspace van de fluxpotten gelijk was aan de omgevingsdruk (persoonlijke opmerking Jordy van 't Hull). De berekende emissieflux wordt gegeven in Figuur B3.2. Na 22 dagen werd door onbekende redenen een lagere $\mathrm{N}_{2} \mathrm{O}$-concentratie gemeten dan na 21 dagen, hetgeen op dat moment leidt tot een 'negatieve' emissieflux. Daarna werden de emissiefluxen weer positief. Na respectievelijk 35 dagen ( $4 \%$ AN) en 44 dagen ( $8 \%$ AN) werden de fluxen 'negatief' en bleven dat tot het einde van de incubatie.

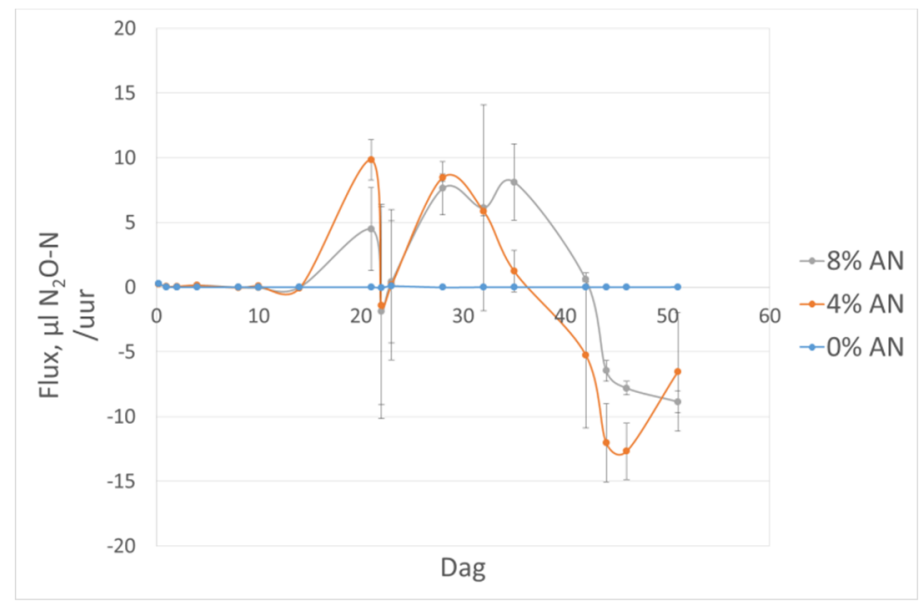

Figuur B3.2 Lachgasemissieflux in de tijd naar de headspace van de afgesloten fluxpotten met mengsels van mineralenconcentraat met op volumebasis $0 \%, 4 \%$ of $8 \%$ van $150 \mathrm{~g} \mathrm{~N} / \mathrm{L}$ ammoniumnitraatoplossing $(A N)$ voor incubatie bij $15^{\circ} \mathrm{C}$. Foutenbalken tonen de standaardafwijking gebaseerd op twee herhalingen.

Verhoging van op volumebasis 4\% AN naar $8 \%$ AN in het mengsel met mineralenconcentraat leidt niet tot een wezenlijke verhoging van de $\mathrm{N}_{2} \mathrm{O}$-emissieflux. Wel veroorzaakt dit een vertraging in het op gang komen van de emissieflux. Wat deze vertraging heeft veroorzaakt, kan met deze verkenning niet worden aangegeven. Er zullen verschillen gecreëerd zijn in de elektrische geleidbaarheid en ammoniumstikstofgehalten van de mengsels, maar of deze verschillen de oorzaken zijn van de remming kan niet uit dit onderzoek worden geconcludeerd. 
Uit de bevinding dat een aandeel van $8 \%$ AN in het mengsel ten opzichte van een aandeel van $4 \%$ AN niet wezenlijk tot een hogere $\mathrm{N}_{2} \mathrm{O}$-emissie leidt, wordt een aanwijzing verkregen dat de voor denitrificatie beschikbare organische stof al bij het lagere aandeel van $4 \%$ AN verbruikt is. Een tekort aan beschikbare organische stof remt dan de denitrificatie.

\section{B3.3.2 Emissie van waterstofsulfide}

\section{B3.3.2.1 Eerste incubatieproef}

Van meet af aan werden witte neerslagen waargenomen (Afbeelding B3.3). Bij nadere inspectie bleken die neerslagen uit grovere deeltjes te bestaan met zwarte insluitsels. Met ultrasone trillingen konden die deeltjes niet of nauwelijks tot kleinere deeltjes verkleind worden. Ook toevoeging van een zeep (Triton X-100) leidde bij ultrasoon suspenderen niet tot kleinere deeltjes.
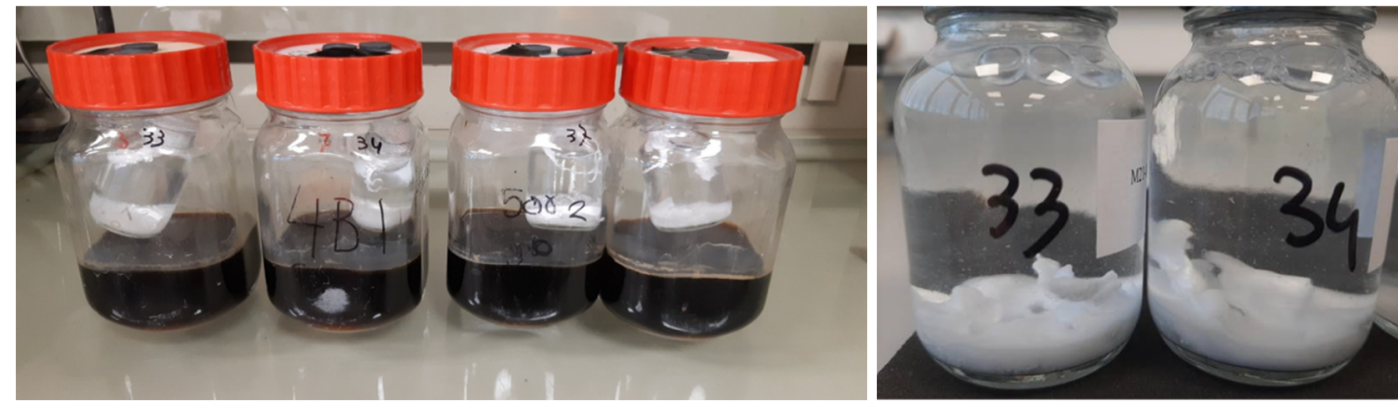

Afbeelding B3.3

Witte neerslag, bestaande uit fijne en grovere aan elkaar gegroeide brokken, in de mee-geïncubeerde bekerglazen met zinkacetaatoplossing in de fluxpotten.

Door het CBLB uitgevoerde testen naar de meting van zwavel in suspensies van 'pro analyse' kwaliteit ZnS toonden aan dat de hoeveelheid terug gemeten ZnS (gemeten als totaalzwavel (S)) afhankelijk was van de opslagduur van de ZnAc met daarin het gesuspendeerde ZnS (Tabel B3.5). In een standaardsuspensie hiervan van een week oud werd door meting nog maar $22 \%$ van de totaal-S die het bevat, teruggevonden. Verder bleek dat hoe groter het aandeel ZnAc op volumebasis in de suspensie is, des te lager de hoeveelheid terug gemeten totaal-S was. Beredeneerd werd dat deeltjes in de loop van de tijd gaan clusteren tot grotere deeltjes die nog wel door de verstuiver van de ICPOES passen, maar het plasma van de ICP-OES niet meer kunnen bereiken. Een hoger volumepercentage van ZnAc met gesuspendeerde $\mathrm{ZnS}$ in het mengsel lijkt dit proces van clusteren aanzienlijk te versnellen.

Tabel B3.5 Verkenning van de hoeveelheid gemeten zinksulfide ( $\mathrm{ZnS}$ ) als percentage van de toegevoegde hoeveelheid ZnS bij verschillende mengverhoudingen op volumebasis van zinkacetaatoplossing (ZnAc) met demiwater en Triton X-100.

\begin{tabular}{|c|c|c|c|c|}
\hline $\begin{array}{c}\text { ZnAc met } \\
\text { gesuspendeerd Zns } \\
\text { (\% van mengsel) }\end{array}$ & $\begin{array}{c}\text { Demiwater } \\
\text { ( } \% \text { van mengsel) }\end{array}$ & $\begin{array}{l}\text { Triton } \mathrm{X}-100 \\
\text { ( } \% \text { van mengsel) }\end{array}$ & $\begin{array}{l}\text { Terug gemeten ZnS } \\
\text { (\% van toegevoegd ZnS) }\end{array}$ & Opmerking \\
\hline 0 & 90 & 10 & 100 & Monster halve dag oud \\
\hline 45 & 45 & 10 & 26 & Monster halve dag oud \\
\hline 68 & 22 & 10 & 8 & Monster halve dag oud \\
\hline 90 & 0 & 10 & 4 & Monster halve dag oud \\
\hline 100 & 0 & 0 & 51 & $\begin{array}{l}\text { Monster een paar uur } \\
\text { oud }\end{array}$ \\
\hline 0 & 90 & 10 & 22 & Monster 1 week oud \\
\hline
\end{tabular}

Door middel van ultrasoneren werd het percentage terug gemeten ZnS van de monsters en stockoplossingen die al een tijdje stonden niet meer hoger. Ultrasoneren kan het proces dat verantwoordelijk is voor de lagere terugmeting dus niet terugdraaien. Op basis van deze resultaten en 
gelet op het verkennende karakter van het onderzoek, is besloten om geen extra tijd meer te steken in het ontwerpen van een geschikte methode voor directe analyse, maar om over te gaan naar een bestaande titratiemethode gebaseerd op een kleuringsreactie (methyleenblauw). De deeltjesgrootte van de deeltjes in de suspensie heeft geen invloed op deze methode, omdat de deeltjes tijdens de titratie geheel oplossen. Enkele monsters werden getitreerd, daarin werd geen zwavel vastgesteld (data niet gegeven). Titratie toonde geen $\mathrm{ZnS}$ aan. Een aanwijzing dat $\mathrm{H}_{2} \mathrm{~S}$ is gevormd, werd dus niet verkregen.

\section{B3.3.2.2 Tweede incubatieproef}

De eerste incubatieproef leverde een forse hoeveelheid precipitaat op die geen ZnS bleek te zijn. Het is mogelijk dat dit precipitaat zinkcarbonaat is geweest. Er is geen onderzoek uitgevoerd naar de chemische samenstelling van dit precipitaat. Beredeneerd is dat zinkcarbonaat naast zinksulfide precipiteerde. De hoeveelheid van $50 \mathrm{ml} Z n A c$ in het bekerglas op $300 \mathrm{ml}$ mengsel van mineralenconcentraat met AS in de fluxpot is mogelijk een te geringe hoeveelheid vloeistof met daardoor een te lage buffercapaciteit. Verhoging van de totale hoeveelheid zink in het bekerglas zou mogelijk wel tot meting van ZnS kunnen leiden. Dit is verkend in een tweede incubatieproef, waarbij een groter bekerglas met $300 \mathrm{ml} \mathrm{ZnAc}$ in een fluxpot met $350 \mathrm{ml}$ mengsel van mineralenconcentraat met AS werd getest.

De bevindingen van deze tweede incubatieproef zijn:

- Alle bekerglazen bevatten opnieuw in meer of mindere mate een witte neerslag.

- Dit keer werden geen zwarte insluitsels aangetroffen in het precipitaat.

- De meeste bekerglazen bevatten (vaak grote) witte schilfers. Het precipitaat in drie van de acht bekerglazen bleek volledig uit kleine deeltjes te bestaan. Geen trend kon worden ontdekt tussen deze waarnemingen en de verschillende behandelingen.

- Alle acht bekerglazen hadden zwavelgehalten onder de aantoonbaarheidsgrens van 0,2 mg S/kg.

In dit onderzoek zijn aanvullende testen met standaardadditie van 'pro analyse' kwaliteit ZnS uitgevoerd om te bevestigen dat de gebruikte meetmethode geschikt is. Deze testen tonen aan dat de gebruikte meetmethode succesvol is in het terug meten van de via standaardadditie toegevoegde $\mathrm{ZnS}$. De emissie van $\mathrm{H}_{2} \mathrm{~S}$ werd onderzocht met twee verkennende incubatieproeven. In beide proeven kon geen precipitatie van ZnS worden vastgesteld. De incubatieproeven geven daardoor geen indicatie dat menging van AS met mineralenconcentraat, voorafgaand aan opslag, leidt tot emissie van $\mathrm{H}_{2} \mathrm{~S}$ tijdens deze opslag.

\section{B3.4 Evaluatie en conclusies}

Risico's op vorming van lachgas $\left(\mathrm{N}_{2} \mathrm{O}\right)$ door bijmenging van een nitraathoudende bemestingsproduct aan mineralenconcentraat en risico's op vorming van waterstofsulfide $\left(\mathrm{H}_{2} \mathrm{~S}\right)$ door bijmenging van een sulfaathoudend bemestingsproduct aan mineralenconcentraat is onderzocht in twee verkennende deelstudies. Hiervoor zijn incubatieproeven uitgevoerd.

Lachgasemissie bij opslag van mengsels van mineralenconcentraat met een nitraathoudend bemestingsproduct is vastgesteld. De mate van emissie wordt niet uitsluitend door de hoeveelheid toegevoegd nitraat bepaald. Een aandeel van op volumebasis $8 \%$ AN, met een concentratie van $150 \mathrm{~g}$ $N / L$, in het mengsel leidde niet tot een hogere mate van denitrificatie t.o.v. een $4 \%$ aandeel van $A N$ in het mengsel. Wel kwam het proces van denitrificatie wat trager op gang bij het mengsel met $8 \%$ AN.

In dit onderzoek is gebruikgemaakt van een mineralenconcentraat geproduceerd uit varkensdrijfmest door het bedrijf Agro America. Het is mogelijk dat dit mineralenconcentraat een hoger gehalte aan makkelijk afbreekbare organische stof heeft dan een mineralenconcentraat geproduceerd uit covergiste varkensdrijfmest (digestaat) zoals die door Groot Zevert Vergisting wordt geproduceerd. De lachgasemissie zou in dat geval bij mengsels van dit laatste mineralenconcentraat met een nitraathoudend bemestingsproduct mogelijk minder groot zijn dan bij dezelfde mengsels met het mineralenconcentraat van Agro America. In het kader van het project Kunstmestvrije Achterhoek worden veldproeven op gras- en maisland uitgevoerd, waarbij de landbouwkundige werkzaamheid van de Groene Weide Meststof (GWM) wordt onderzocht. In het kader van dat onderzoek is vastgesteld 
dat het gehalte aan nitraatstikstof in de GWM bij opslag in IBC's over een periode van enkele maanden geleidelijk daalt, waardoor nitraatstikstof uiteindelijk vrijwel verdwijnt. De resultaten hiervan worden op het moment van schrijven geanalyseerd en worden later dit jaar gepubliceerd (Ehlert, 2021 in voorbereiding). Er is daardoor een aanwijzing dat ook in een mengsel van uit digestaat geproduceerd mineralenconcentraat en een nitraathoudend bemestingsproduct op den duur denitrificatie van nitraat plaatsvindt. Dit resulteert daarna in vervluchtiging van lachgas en/of stikstof $\left(\mathrm{N}_{2}\right)$.

Emissies van waterstofsulfide werden niet waargenomen bij incubatie van mengsels van ammoniumsulfaatoplossing met uit digestaat geproduceerd mineralenconcentraat. De methodiek om deze emissie van waterstofsulfide te meten, vraagt aandacht. Er is nieuw onderzoek ontworpen om deze emissies nader te onderzoeken met een andere meetmethode. De verslaglegging van dit onderzoek behoort niet tot deze rapportage. 


\section{Bijlage 4}

Onderzoeksrapport van het bedrijf BLUE-tec

\section{WAGENINGEN}

UNIVERSITY \& RESEARCH

Leo van Amstel, Henry van Kaathoven, Radjes Nidhansing en Joep Verbunt wn

Jasper van Puffelen en Phillip Ehlert

12 augustus 2020

Memo

Beste Leo van Amstel,

Deze memo bevat de resultaten van de chemische analyses ${ }^{1}$ van de membraandestillatieproef met het stikstof-kalium (NK)-concentraat van het bedrijf Kumac. De Landwirtschaftskammer Nordrhein-Westfalen heeft de aan Jasper van Puffelen meegegeven monsters van de proef chemisch geanalyseerd. Via de gemeten concentraties is de behaalde indikkingsfactor op massabasis berekend. Van elke ingaande $\mathrm{kg} \mathrm{NK}$-concentraat kwam circa $18 \%$ terecht in het retentaat en circa $82 \%$ in het permeaat. Dat is berekend uit de verschillen in de kaliumconcentratie van de in- en uitgaande stromen. Het ingaande NK-concentraat werd door de membraandestillatie dus ongeveer 5,5 keer ingedikt. Praktisch $100 \%$ van de componenten $\mathrm{P}, \mathrm{K}, \mathrm{Mg}, \mathrm{Ca}, \mathrm{Fe}, \mathrm{Cu}, \mathrm{S}, \mathrm{Zn}$ en organische stof in het ingaande NKconcentraat kwam terecht in het retentaat. Dit geldt niet voor $\mathrm{N}$ en $\mathrm{N}-\mathrm{NH}_{4}$. Van de $\mathrm{N}$ $\mathrm{NH}_{4}$ in het ingaande $\mathrm{NK}$-concentraat eindigde circa $48 \%$ in het retentaat en circa $51 \%$ in het permeaat. De stikstof in het ingaande NK-concentraat bestond voor $93 \%$ uit $\mathrm{N}-\mathrm{NH}_{4}$. Uit het retentaat zijn zoutkristallen gezeefd (zie onderstaande foto).

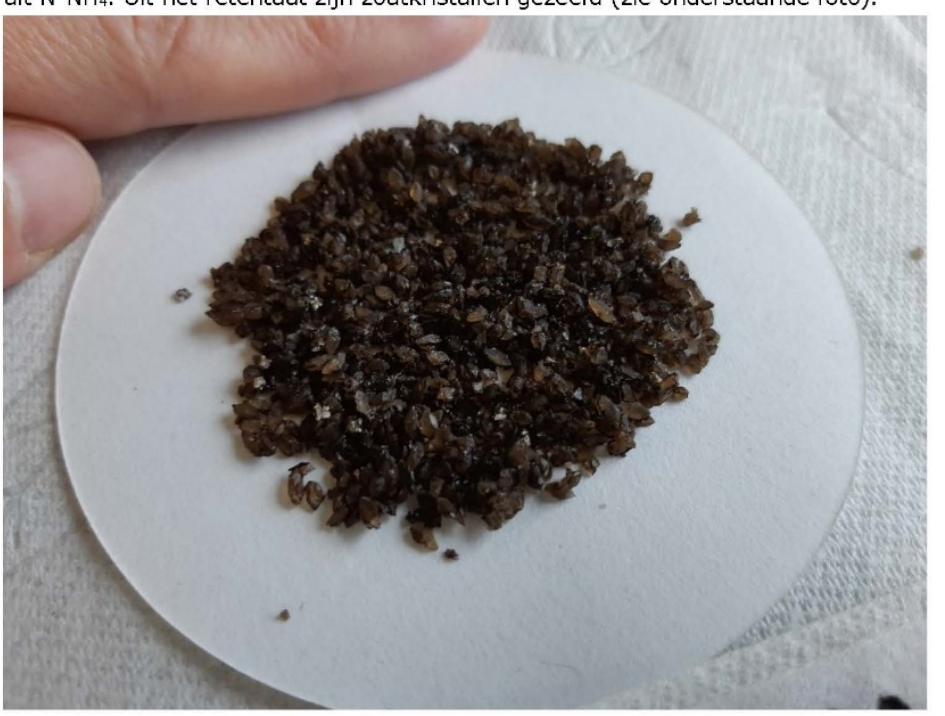

${ }^{1}$ De analysemethoden zijn beschreven in hoofdstuk 2.1 van dit rapport tenzij anders aangegeven.

DATUR

12 augustus 2020

ONDTRWCRs

Massabalans van de

membraandestillatieproef met

NK-concentraat

INERNET

www.wur.nl

CONTACTPERSOON

Jasper L. van Puffelen

тенғоом

$+31(0) 317489675$

E-MAII

jasper.vanpuffelen@wur.n! 
Samenstelling van het ingaande NK-concentraat, het retentaat voor en na afzeven van de zoutkristallen en het permeaat van de membraandestillatie. 年

\begin{tabular}{|c|c|c|c|c|c|}
\hline & & $\begin{array}{l}\mathrm{NK}- \\
\text { concentraat }\end{array}$ & $\begin{array}{l}\text { inclusief } \\
\text { zoutkristallen }\end{array}$ & $\begin{array}{l}\text { afzeven } \\
\text { zoutkristallen }\end{array}$ & \\
\hline Drogestof & $\% \mathrm{~m} / \mathrm{m}$ & 3,4 & $\bar{c}$ & 19 & 0,03 \\
\hline $\begin{array}{l}\text { Organische } \\
\text { stof }\end{array}$ & $\% \mathrm{~m} / \mathrm{m}$ & 0,83 & c & 4,86 & $<0,10$ \\
\hline $\mathrm{N}$ & $\% \mathrm{~m} / \mathrm{m}$ & 0,71 & c & 2,10 & 0,42 \\
\hline $\mathrm{N}-\mathrm{NH}_{4}$ & $\% \mathrm{~m} / \mathrm{m}$ & 0,66 & 1,7 & 1,7 & 0,41 \\
\hline $\mathrm{P}^{\mathrm{a}}$ & $\% \mathrm{~m} / \mathrm{m}$ & $<0,0044$ & 0,010 & 0,010 & $<0,0083$ \\
\hline $\mathrm{K}^{\mathrm{b}}$ & $\% \mathrm{~m} / \mathrm{m}$ & 0,80 & 4,4 & 3,9 & $<0,060$ \\
\hline $\mathrm{Mg}$ & $\% \mathrm{~m} / \mathrm{m}$ & 0,02 & 0,13 & 0,12 & $<0,00071$ \\
\hline $\mathrm{Ca}$ & $\% \mathrm{~m} / \mathrm{m}$ & 0,01 & 0,018 & 0,018 & $<0,00071$ \\
\hline $\mathrm{Fe}$ & $\% \mathrm{~m} / \mathrm{m}$ & 0,007 & 0,028 & 0,028 & $<0,001$ \\
\hline $\mathrm{Cu}$ & $\% \mathrm{~m} / \mathrm{m}$ & $<0,0001$ & 0,0036 & 0,0037 & $<0,0001$ \\
\hline $\mathrm{s}$ & $\% \mathrm{~m} / \mathrm{m}$ & 0,42 & 2,8 & 2,6 & $<0,010$ \\
\hline $\mathrm{Zn}$ & $\% \mathrm{~m} / \mathrm{m}$ & $<0,0005$ & 0,00075 & 0,00075 & $<0,0005$ \\
\hline $\begin{array}{l}\mathrm{pH} \text { (in een } \\
\mathrm{CaCl}_{2-} \\
\text { oplossing) }\end{array}$ & - & 8,1 & c & 8,7 & 9 \\
\hline $\begin{array}{l}\mathrm{C} / \mathrm{N}- \\
\text { verhouding }\end{array}$ & - & 1 & c & 1 & c \\
\hline Dichtheid & $\mathrm{kg} / \mathrm{l}$ & 1,013 & c & 1,15 & 0,993 \\
\hline
\end{tabular}

a omrekenfactor van $\mathrm{P}$ (fosfor) naar $\mathrm{P}_{2} \mathrm{O}_{5}$ (fosfaat): $\mathrm{P} * 2,2915=\mathrm{P}_{2} \mathrm{O}_{5}$.

b omrekenfactor van $\mathrm{K}$ (kalium) naar $\mathrm{K}_{2} \mathrm{O}$ (kali): $\mathrm{K} * 1,205=\mathrm{K}_{2} \mathrm{O}$.

c niet gemeten.

Zeven van verschillende maaswijdtes zijn gebruikt om de zoutkristallen in het retentaat af te scheiden. De natte zoutkristallen zijn daarna 22 uur bij $40{ }^{\circ} \mathrm{C}$ gedroogd. Per kg retentaat is circa 15 gram aan gedroogde zoutkristallen geoogst.

Massa afgezeefde zoutkristallen voor de verschillende maaswijdtes per kg retentaat van de membraandestillatie.

\begin{tabular}{|l|c|}
\hline $\begin{array}{l}\text { Maaswijdte zeef } \\
(\mathrm{mm})\end{array}$ & Gedroogde massa per kg retentaat $(\mathrm{g})$ \\
\hline 2,0 & 1,5 \\
\hline 1,4 & 5,6 \\
\hline 0,6 & 4,8 \\
\hline 0,425 & 3,3 \\
\hline Totaal & 15,3 \\
\hline
\end{tabular}

Van de gedroogde zoutkristallen is $0,15 \mathrm{~g}$ opgelost in $40 \mathrm{ml} \mathrm{0,1} \mathrm{M}$ zoutzuur waarna de oplossing chemisch is geanalyseerd door het CBLB, onderdeel van WUR. De resultaten daarvan zijn omgerekend naar de gedroogde samenstelling. 
Samenstelling van de gedroogde zoutkristallen uit het retentaat van de membraandestillatie.

\begin{tabular}{|l|c|}
\hline Parameter & Percentage van totale gedroogde massa \\
\hline $\mathrm{N}-\mathrm{NH}_{4}$ & 1,8 \\
\hline $\mathrm{P}$ & 0,0059 \\
\hline $\mathrm{K}$ & 36 \\
\hline $\mathrm{Mg}$ & 1,0 \\
\hline $\mathrm{Ca}$ & 0,025 \\
\hline $\mathrm{Fe}$ & 0,018 \\
\hline $\mathrm{Cu}$ & 0,0020 \\
\hline $\mathrm{S}$ & 16 \\
\hline $\mathrm{Al}$ & 0,0010 \\
\hline $\mathrm{Mn}$ & 0,0003 \\
\hline $\mathrm{Na}$ & 1,0 \\
\hline Totaal & 56 \\
\hline
\end{tabular}

De componenten die in de chemische analyse van de zoutkristallen zijn meegenomen verklaren circa $56 \%$ van de totale massa van de gedroogde zoutkristallen. Analyse van de gedroogde zoutkristallen met $\mathrm{x}$-ray diffraction (XRD) laat zien dat de kristallijne zwavel die het bevat aanwezig is in de vorm van sulfaten $\left(\mathrm{K}_{2} \mathrm{SO}_{4}, \mathrm{KSO}_{3}\right.$ en $\mathrm{K}_{3} \mathrm{Na}\left(\mathrm{SO}_{4}\right)_{2}$ ). Het is daarom waarschijnlijk dat een groot deel van de nog niet verklaarde massa van de gedroogde zoutkristallen bestaat uit de zuurstofatomen in deze sulfaten. Als wordt aangenomen dat alle zwavel aanwezig is als sulfaat dan verklaart dat circa $32 \%$ extra van de zoutkristalmassa bovenop de al verklaarde $56 \%$

Percentage van de componenten in het ingaande NK-concentraat dat terechtkomt in het retentaat, de afgezeefde zoutkristallen en het permeaat van de membraandestillatie.

\begin{tabular}{|l|l|l|l|}
\hline Parameter & $\begin{array}{l}\text { Retentaat (inclusief } \\
\text { zoutkristallen) }\end{array}$ & $\begin{array}{l}\text { Zoutkristallen } \\
\text { (afgezeefd) }\end{array}$ & Permeaat \\
\hline \hline Totale massa & 18 & 0,015 & 82 \\
\hline${\mathrm{N}-\mathrm{NH}_{4}}$ & 48 & 0,8 & 51 \\
\hline $\mathrm{P}$ & 100 & ${ }^{a}$ & ${ }^{a}$ \\
\hline $\mathrm{K}$ & 100 & 12,7 & ${ }^{\mathrm{a}}$ \\
\hline $\mathrm{Mg}$ & 100 & 11,7 & ${ }^{\mathrm{a}}$ \\
\hline $\mathrm{Ca}$ & 100 & 0,9 & ${ }^{a}$ \\
\hline $\mathrm{Fe}$ & 100 & 0,7 & ${ }^{a}$ \\
\hline $\mathrm{Cu}$ & 100 & ${ }^{a}$ & ${ }^{a}$ \\
\hline $\mathrm{S}$ & 100 & 10,9 & ${ }^{a}$ \\
\hline
\end{tabular}

kan niet berekend worden vanwege één of meerdere gemeten concentraties onder de kwantificeringslimiet (LOQ).

Het ingaande NK-concentraat had op massabasis een verhouding $\mathrm{N}-\mathrm{NH}_{4} / \mathrm{K}$ van 0,83 $\left(\mathrm{N}-\mathrm{NH}_{4} / \mathrm{K}_{2} \mathrm{O}\right.$ is 0,69$)$. Ongeveer $13 \%$ van de kalium uit het ingaande $\mathrm{NK}$-concentraat werd door afzeven van zoutkristallen uit het retentaat verwijderd. Dit afzeven geeft een (te) kleine verbetering van de $\mathrm{N} / \mathrm{K}$-verhouding op massabasis (berekend als $\mathrm{N}$ $\mathrm{NH}_{4} / \mathrm{K}$ ) van 0,44 in het retentaat inclusief zoutkristallen naar 0,39 in het retentaat zonder zoutkristallen. Voor $\mathrm{N}-\mathrm{NH}_{4} / \mathrm{K}_{2} \mathrm{O}$ is deze verhoudingsafname van 0,37 naar 0,33 . De aanzienlijk lagere verhouding $\mathrm{N}-\mathrm{NH}_{4} / \mathrm{K}$ in het retentaat ten opzichte van het ingaande $\mathrm{NK}$-concentraat is het resultaat van meeliften van gasvormig ammoniak door het membraan. 
12 augustus 2020

4 van 4
Circa $51 \%$ van de $\mathrm{N}-\mathrm{NH}_{4}$ lift met de waterdamp mee door het membraan. Membraandestillatie kan daardoor stikstof verwijderen en dat leidt tot een ongeveer twee keer lagere N/K-verhouding in het retentaat ten opzichte van het ingaande NKconcentraat. Dit resulteert echter in een ammoniakwater (permeaat) met een $\mathrm{pH}$ van 9. Wil je het meeliften van ammoniak en de hoge $\mathrm{pH}$ van het permeaat voorkomen, dan zal de $\mathrm{pH}$ van het $\mathrm{NK}$-concentraat verlaagd moeten worden tot naar verwachting onder de 7 (afhankelijk van de temperatuur). Dit zodat praktisch alle $\mathrm{N}-\mathrm{NH}_{4}$ aanwezig is als ammonium in plaats van deels als ammoniak. Dat kost echter veel (zwavel)zuur vanwege de bufferende werking van NK-concentraat door de aanwezigheid van o.a. bicarbonaten. Toevoeging van een zuur, specifiek ook zwavelzuur, beïnvloedt mogelijk de hoeveelheid kalium die als zoutkristallen neerslaat.

Afzeven van de zoutkristallen levert op basis van de in deze proef gebruikte procescondities nog geen perspectief om de N/K-verhouding van het geproduceerde retentaat aanzienlijk te verhogen. RN Solutions geeft aan dat een hogere indikking dan in deze proef is behaald mogelijk is met membraandestillatie. Onderzocht moet worden of een hogere indikking ook leidt tot het verwachte hogere percentage van ingaand kalium dat dan als zoutkristal wordt afgescheiden. Ook zou onderzocht kunnen worden of er voor dit proces geschikte membranen zijn die ammoniak (deels) tegenhouden maar waterdamp wel doorlaten.

Een aandachtspunt is dat het NK-concentraat van Kumac een twee tot drie keer hoger zwavelgehalte heeft dan het NK-concentraat van Maatschap Van Amstel. De hoeveelheid uit het NK-concentraat van Van Amstel af te scheiden kalium, als zoutkristallen, is daarom bij gelijke procescondities mogelijk kleiner.

Kortom, membraandestillatie kan een hoge indikking van $\mathrm{NK}$-concentraat behalen waarbij echter wel zuurtoevoeging nodig is om te voorkomen dat $\mathrm{N}-\mathrm{NH}_{4}$ het membraan passeert. Door het indikken slaan kaliumzouten neer waarbij kristallen worden gevormd die groot genoeg zijn om met een zeef af te scheiden. De techniek biedt daarmee perspectief voor het scheiding van stikstof en kalium indien het percentage, als zoutkristallen, afgevangen kalium kan worden verhoogd.

Met vriendelijke groet,

Jasper van Puffelen en Phillip Ehlert

12 augustus 2020 
Wageningen Environmental Research Postbus 47

6700 AA Wageningen

T 0317480700

www.wur.nl/environmental-research

Wageningen Environmental Research

Rapport 3120

ISSN 1566-7197
De missie van Wageningen University \& Research is 'To explore the potential of nature to improve the quality of life'. Binnen Wageningen University \& Research bundelen Wageningen University en gespecialiseerde onderzoeksinstituten van Stichting Wageningen Research hun krachten om bij te dragen aan de oplossing van belangrijke vragen in het domein van gezonde voeding en leefomgeving. Met ongeveer 30 vestigingen, 6.800 medewerkers ( $6.000 \mathrm{fte}$ ) en 12.900 studenten behoort Wageningen University \& Research wereldwijd tot de aansprekende kennisinstellingen binnen haar domein. De integrale benadering van de vraagstukken en de samenwerking tussen verschillende disciplines vormen het hart van de unieke Wageningen aanpak. 


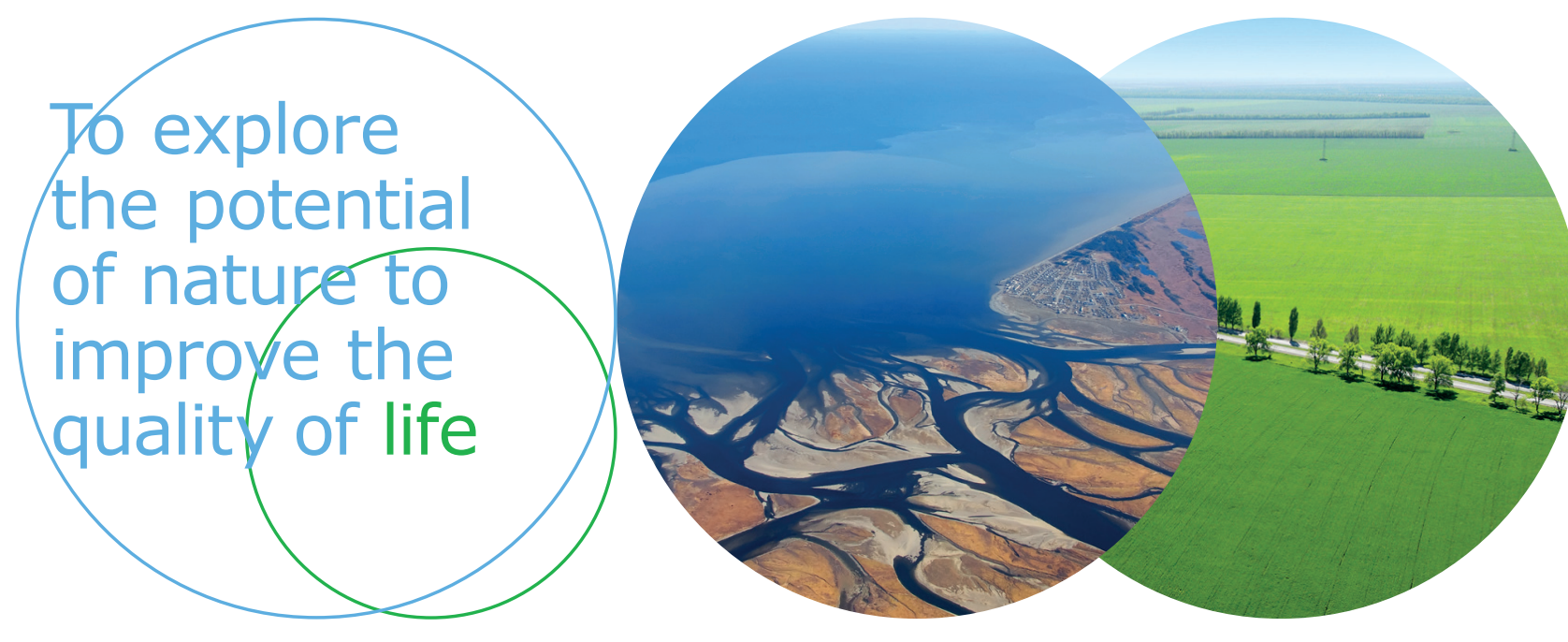

Wageningen Environmental Research Postbus 47

$6700 \mathrm{AB}$ Wageningen

T 317480700

www.wur.nl/environmental-research

Rapport 3120

ISSN 1566-7197
De missie van Wageningen University \& Research is 'To explore the potential of nature to improve the quality of life'. Binnen Wageningen University \& Research bundelen Wageningen University en gespecialiseerde onderzoeksinstituten van Stichting Wageningen Research hun krachten om bij te dragen aan de oplossing van belangrijke vragen in het domein van gezonde voeding en leefomgeving. Met ongeveer 30 vestigingen, 6.800 medewerkers (6.000 fte) en 12.900 studenten behoort Wageningen University \& Research wereldwijd tot de aansprekende kennisinstellingen binnen haar domein. De integrale benadering van de vraagstukken en de samenwerking tussen verschillende disciplines vormen het hart van de unieke Wageningen aanpak. 